\title{
A JUDICIALIZAÇÃO DOS CONFLITOS DE JUSTIÇA DISTRIBUTIVA NO BRASIL: O PROCESSO JUDICIAL NO PÓS-1988
}

\author{
Tese apresentada à Faculdade de Direito da \\ Universidade de São Paulo (USP), sob a \\ orientação do Prof. Titular Dr. José Roberto \\ dos Santos Bedaque, como requisito parcial \\ para a obtenção do título de Doutor em \\ Direito Processual.
}

Candidato: Marcos Paulo Verissimo

\author{
Universidade de São Paulo \\ Faculdade de Direito \\ Departamento de Direito Processual
}

São Paulo, janeiro de 2006 
Banca Examinadora: 
Para Erica, e para os dois pequenos milagres que ela carrega consigo (Ana e Pedro). 

"Abandonemos, pois, esse ensino inoperante de regras e exceções. Estudemos a língua."

(Celso Cunha, Uma política do idioma, 1965) 


\section{Agradecimentos}

É costumeiro dizer que os trabalhos acadêmicos são sempre obras coletivas. Esse é um costume justo porque, para além do esforço individual de organização de certas idéias e redação de um texto, há sempre, por trás das idéias e dos textos, um sem número de leituras, conversas, debates, concordâncias, discordâncias, surpresas e indignações, ligadas à interlocução do autor com terceiros, que formam um conjunto de relações capazes de moldar repertórios e formas de pensar. Minha tese de doutoramento não foge a essa regra. Suas falhas, como se costuma dizer com a mesma justeza, são creditáveis apenas ao autor. Mas as virtudes que ela tiver são fruto da ajuda de várias pessoas, muitas mais do que eu poderia mencionar neste espaço restrito.

Sou grato, antes de tudo, a meu orientador. O Prof. José Roberto dos Santos Bedaque foi quem primeiro confiou em mim, aceitando-me, recém saído dos bancos da graduação, no programa de pós-graduação da Faculdade de Direito da Universidade de São Paulo. Teve a paciência de corrigir-me os erros e de orientar minha dissertação de mestrado. Depois, confiou novamente em meu trabalho e aceitou orientar a elaboração desta tese, sugerindo-me caminhos e idéias. Se eu não pudesse ter contado com sua ajuda, orientação e confiança, este trabalho certamente não existiria. Professor inato, colecionador de homenagens de seus alunos, além de marcar-me a formação acadêmica ainda infundiu em mim o gosto por dar aulas. Sou-lhe grato também por isso.

A pesquisa que originou este trabalho foi empreendida em grande parte ao amparo de um programa de visiting scholar que desenvolvi, durante o primeiro semestre de 2005, junto à Faculdade de Direito da Universidade de Yale (New Haven, CT, E.U.A.). Em Yale, fui atenciosa e gentilmente acolhido pelo Prof. Owen M. Fiss, que pacientemente se dispôs a debater comigo muitas das idéias contidas nesse texto. Por sua acolhida, por colocar os 
fantásticos recursos da Yale Law School à minha disposição e por ouvir pacientemente minhas dúvidas e inquietações, sou-lhe imensamente grato.

Alguns amigos colaboraram decisivamente para viabilizar a realização desse programa em Yale. Por isso, e por tantas outras coisas, sou grato a Carlos Alberto de Salles, a Paulo Todescan Lessa Mattos, a Jean Paul Cabral Veiga da Rocha e a Caio Mário da Silva Pereira Neto. Carlos foi-me, ainda, interlocutor atencioso e constante no Programa de Pós-Graduação da USP, abrindo-me as portas para um sem número de oportunidades acadêmicas, incluindo a grata oportunidade de trabalhar como seu assistente. Fez, também, críticas cruciais a este texto, sobretudo quando examinou-o em sede de qualificação. Paulo, entre tantas coisas, fez comentários valiosos sobre a terceira parte do texto. Caio teve a gentileza adicional de acolher-me, junto com a Fernanda, em minha chegada a New Haven, fazendo meu processo de acomodação muito mas fácil e agradável.

Também em New Haven recebi a atenção e a ajuda de Mariana Mota Prado e Márcio Soares Grandchamp. Além de zelarem pelo meu conforto e de me apresentarem os recursos da faculdade, foi de uma conversa com Mariana que surgiram quase todos os exemplos que uso na segunda parte do trabalho. A partir das conversas com Márcio foram delimitadas outras tantas linhas divisoras construídas em meu texto entre as categorias da distribuição e da comutação.

Nos últimos oito anos, encontrei no programa de pós-graduação da USP inumeráveis interlocutores para minhas idéias. Esses interlocutores foram tantos que eu teria o receio de, enumerando-os, cometer graves injustiças. Por isso, agradeço a todos na pessoa de meu querido amigo Sidnei Amendoeira Junior. Ainda no contexto do programa de pós-graduação da USP, sou especialmente grato aos professores Ada Pellegrini Grinover e Kazuo Watanabe, que me aceitaram como assistente em suas disciplinas de pós-graduação. O Professor Kazuo Watanabe fez, ainda, importantíssimos comentários a uma versão embrionária deste texto, por ocasião de meu exame de qualificação.

Ao Professor Calixto Salomão Filho sou grato também pela interlocução, e por admitir-me na delegação brasileira do SELA (Seminario en Latinoamérica de Teoría Constitucional y Política). 
Pela interlocução constante agradeço também a meus colegas do Núcleo de Estudos e Debates do CEBEPEJ (Centro Brasileiro de Estudos e Pesquisas Judiciais), fazendo-o na pessoa de sua coordenadora, Professora Maria Tereza Sadek. Agradeço ainda, especialmente, a Susana Henriques da Costa, por franquear-me extenso material relativo ao Ministério Público do Estado de São Paulo, e a Fernando da Fonseca Gajardoni, por esclarecer-me quanto à existência de vasto contencioso objetivando a implementação de abrigos para menores em São Paulo. Ao meu amigo Paulo Eduardo Alves da Silva agradeço, entre tantas coisas, por ouvir com paciência meus devaneios.

Na Sociedade Brasileira de Direito Público tive a oportunidade única de colocar as idéias centrais deste texto à prova - e no melhor dos laboratórios: a sala de aula. Sou grato a Carlos Ari e a Roberta Sundfeld, e também a Conrado Hübner Mendes por me acolherem na SBDP e por me deixarem organizar, a partir das preocupações que circundam esta tese, todo um módulo de seu curso anual de direito constitucional. Conrado teve, ainda, a gentileza de ler e comentar a primeira parte do texto.

Os originais foram também lidos e gentilmente revistos por Flavia Serizawa e Silva. Thiago Junqueira, dedicado aluno, ocupou-se da revisão geral de referências. As últimas idéias foram discutidas, durante o fechamento do texto, com Rafael Oliva.

Dois extraordinários advogados não estiveram implicados, diretamente, na elaboração deste texto, mas são amigos que me ajudaram em tantas coisas que eu não poderia deixar de referi-los aqui. A Moshe B. Sendacz e a Domingos F. Refinetti faço, portanto, um agradecimento especial.

Sou enormemente grato, por variadíssimas razões, a Debora Inês Kram Baumöhl. Ela tem se mostrado, ao longo dos últimos oito anos, uma amiga insuperável. Outro amigo insuperável tem-me sido, na vida e na academia, Diogo R. Coutinho. Ele reviu meu texto todo, ouviu-me falar em Tiradentes das primeiras idéias que geraram esta tese, fez comentários fundamentais e, como se não bastasse, saiu da minha casa poucos minutos antes destes agradecimentos começarem a ser escritos, pois aqui tinha vindo para saber se eu precisava de alguma ajuda com a editoração final do texto.

A Erica, por fim, sou grato por tudo. Por absolutamente tudo (e, por que não, pela revisão do texto também...). 


\section{Índice}

Introdução

\section{Primeira Parte \\ Judicialização da Política: Conceito, Caminhos, Problemas}

Introdução .

I. Medo da maioria e medo da minoria: dois paradigmas para a atuação das cortes de justiça.

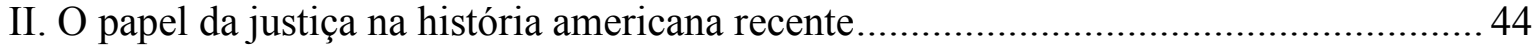

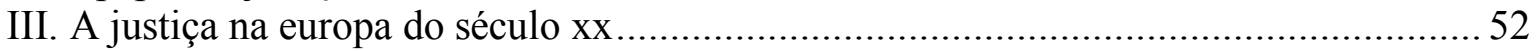

IV. Justiça, autoritarismo e transição democrática: o papel do judiciário na

América Latina.

V. A judicialização da política no Brasil da Nova República ............................................ 67

VI. A crítica à ação expandida do poder judiciário.......................................................... 76

\section{Segunda Parte \\ Entre Direito e Política: A Crítica Instrumental (e uma Proposta para sua Interpretação)}

Introdução

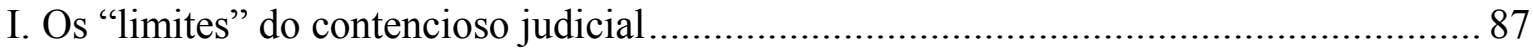

II. Justiça distributiva e justiça corretiva: uma perspectiva de análise............................ 103

III. A transição do direito para o interesse.............................................................. 125

IV. A estrutura da justiça entre a retribuição e o direito subjetivo: crise do modelo liberal e

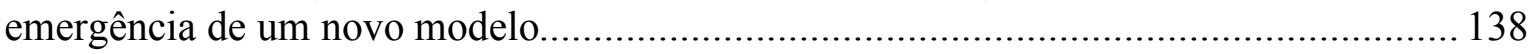

\section{Terceira Parte}

Transformações na Justiça Civil: a Década de 1990 e o Juiz-Herói Brasileiro

Introdução

I. Transformações na justiça e no processo: uma imagem do contencioso civil brasileiro em "fin de siècle".

II. A transformação interpretada: a admissão em juízo entre bilateralidade

e policentrismo.

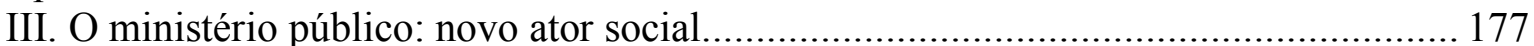

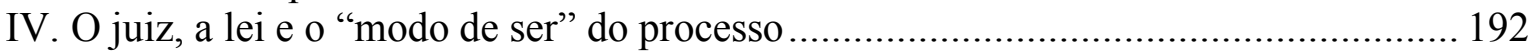


V. Tempo e autoridade na estrutura das decisões

198

VI. Racionalidade, Irracionalidade e Isonomia: concentração decisória e vinculação pelo precedente nas tentativas recentes de reforma

Conclusão.

Resumo

Abstract

Sommaire

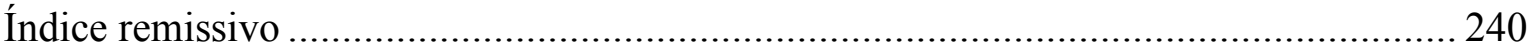

Bibliografia 244 


\section{Introdução}

Genericamente falando, este é um trabalho que trata do processo de judicialização da política no Brasil. Como o tema, assim vagamente considerado, é excessivamente vasto para ser objeto de uma tese de doutoramento, foi preciso empreender nele um recorte temático substancial. Como resultado, o enfoque aqui proposto restringe-se à análise desse processo sob a perspectiva dos reflexos desestruturadores que ele parece ter lançado sobre os mecanismos judiciais de solução de controvérsias no direito brasileiro, sobretudo no plano dos conflitos coletivos.

A hipótese de trabalho é, basicamente, a de que a estrutura normativa fundamental, organizadora do processo judicial no Brasil, tem transformado-se silenciosa mas importantemente, sobretudo a partir de necessidades ligadas à solução de conflitos coletivos conectados, direta ou indiretamente, a problemas distributivos (conflitos envolvendo, grosso modo, decisões sobre bens comuns, sobre bens ainda não apropriados ou sobre bens impossíveis de serem apropriados individualmente por alguém). Subvertendo certos cânones da atividade judiciária ditados pela tradição liberal, a judicialização dos conflitos políticos tem mudado a face e o modo de ser do processo judicial brasileiro, que passa a condicionar-se pela necessidade nova de dar conta desses conflitos distributivos e de empreender uma atividade de gestão de interesses, sendo difícil, contudo, prever, desde logo, os efeitos de longo prazo que disso decorrerão.

Sobre o tema da judicialização da política muito se tem falado, inclusive no Brasil, e sob muitos prismas diferentes. A par dessa multiplicidade de enfoques, a maior parte do debate passa ao largo do enfoque aqui proposto, circundando, apenas, questões representativas e de teoria democrática, ou ligadas a problemas institucionais relacionados às ineficiências geradas pelo aparelho judiciário em relação à economia nacional. 
Em sua primeira vertente, o debate acima referido assume uma feição crítica e ataca a expansão do aparelho judiciário sob o ponto de vista da produção e aceitação de suas decisões. Em suma, nesse viés, os críticos da expansão recente do papel das cortes de justiça apontam graves déficits democráticos que seriam gerados pela intromissão de juízes em questões de política pública.

Sobretudo, segundo certo mainstream da crítica acima apontada, gravitaria em torno do fenômeno um problema duplo de legitimidade, revelado tanto a priori quanto $a$ posteriori.

Por um lado, os juízes estariam se tornando atores políticos, mas sem que suas ações tivessem respaldo anterior de cunho representativo (os juízes brasileiros não são eleitos por voto popular, ao contrário do que acontece com os membros do Congresso Nacional, com os membros das casas legislativas estaduais e municipais e com a chefia do Executivo nos diferentes níveis da federação).

Por outro lado, esses juízes também não são pessoalmente responsabilizáveis por suas decisões, ao menos no que se refere ao mérito delas, e não podem ser destituídos do cargo em virtude do exercício equivocado da judicatura, como ocorre, por exemplo, com os maus administradores públicos, que por meio de eleições periódicas também podem, em regime de controle posterior, ser "punidos" pelas más escolhas que acaso tenham feito.

É verdade que, para além desse mainstream, considerável literatura também tenta demonstrar o exato oposto, isto é, que a ação das cortes de justiça sobre temas de política pública tem, sim, potencial democrático importante, na medida em que permite a introdução na agenda política de questões que, de outro modo, não ingressariam nela, por incapacidade dos grupos de interesse respectivos de atuar efetivamente no espaço político representativo formal.

Conforme procuro demonstrar, ainda que incidentalmente, mais adiante neste trabalho - sobretudo em sua conclusão - isso acontece, ao menos no caso brasileiro, porque, entre outros fatores, as cortes de justiça acabaram se tornando particularmente permeáveis à ação de grupos minoritários originalmente excluídos do processo político tradicional, sobretudo nos segmentos intermediários da sociedade. 
De qualquer forma, quer apontando déficits, quer indicando potenciais democráticos, esse debate que procurei referir acima trabalha o tema da judicialização, como dito, sob o prisma da legitimidade, envolvendo, em última análise, diferentes concepções de democracia, diferentes leituras do princípio majoritário e diferentes considerações sobre a função da adjudicação constitucional no Estado de Direito.

Como já referido, um enfoque bastante diferente desse, mais ainda assim comum, é aquele institucionalista, focado nos problemas postos pela democratização latinoamericana e pela abertura das economias periféricas ao jogo do comércio mundial. Esse enfoque preocupa-se, basicamente, com as externalidades geradas pela ação judiciária inflacionada em um contexto de desenvolvimento incompleto e de necessidade de atração de investimentos, cuidando, bem assim, de debater os custos de uma máquina judiciária ineficiente e imprevisível.

Nesta abordagem confundem-se, especificamente no que diz respeito ao debate brasileiro, dois problemas algo distintos. Um é, propriamente, o da expansão do papel político das cortes de justiça, nos moldes desenhados acima e que serão melhor discutidos ao longo deste trabalho. $\mathrm{O}$ outro diz respeito ao funcionamento da máquina judiciária no desempenho de suas funções mais tradicionais de solução de conflitos privados, adjudicação e garantia de direitos de propriedade. Em comum no enfoque desses problemas distintos há, sobretudo, o tema da eficiência.

No que respeita à questão do papel político das cortes, ainda segundo esse enfoque institucionalista, ele retiraria do órgão judiciário sua condição de aplicador neutro das garantias de propriedade outorgadas pela legislação civil e comercial, espalhando, em primeiríssimo lugar, incertezas sobre o ambiente econômico. Na linha desse argumento, cada decisão que interfere com uma política regulatória, por exemplo, ou que deixa de reconhecer um crédito com base em princípios sociais ou em considerações ligadas ao sinalagma real dos contratos, em outro exemplo, agregaria uma sensação de incerteza no contexto dos negócios que seria imediatamente interpretada pelos agentes econômicos como um risco de investimento, o qual, por sua vez, é imediatamente precificado. Através do código preço as incertezas criadas por um judiciário politizado seriam continuamente transformadas em custos adicionais de investimento, criando-se, assim, ineficiências crescentes que funcionariam como um freio importante para o desenvolvimento das economias periféricas como a brasileira. 
Já no que diz respeito ao desempenho da máquina judiciária em suas funções tradicionais de adjudicação de conflitos, o argumento muda um pouco de rumo, encarando o judiciário agora como um grande prestador de serviços de cobrança. Quanto mais eficiente ele for, mais baratas e simples ficam sendo as garantias, menores serão os spreads bancários, menores os custos e riscos de investimentos. Reversamente, quanto mais morosa e ineficiente for a máquina judiciária, quanto menor a sua capacidade de efetivar os direitos de crédito, mais difícil será o investimento, maiores e melhores terão que ser as garantias oferecidas pelos potenciais tomadores de crédito, maiores serão os spreads bancários.

$\mathrm{Na}$ linha desse argumento, que tento aqui resumir de forma brutalmente simplificadora, a politização da máquina judiciária nacional, espalhando suas incertezas sobre o ambiente econômico, adicionada à profunda morosidade e ineficiência do judiciário em sua feição de "cobrador de contas", fazem dele uma instituição atravancadora do desenvolvimento nacional. Em um recente estudo conduzido pelo economista Armando Castelar Pinheiro", aduz-se que tal ineficiência "roubaria", anualmente, um quinto do potencial de crescimento econômico do país. ${ }^{2}$

Como dito acima, esse viés institucionalista, ao lado das discussões de legitimidade, tem representado o núcleo fundamental do debate relativo à judicialização da política no contexto brasileiro pós 1988. Ainda que ambos esses temas remetam a questões que perpassam todo o texto desse trabalho, o enfoque que quis dar aqui foi diferente.

Para melhor compreendê-lo, é preciso fazer referência a uma terceira linha de análise, que se centra naquilo que os americanos chamam de "institutional capacity" e que prefiro referir por capacidade instrumental. ${ }^{3}$

Na linha desse debate, faz-se a critica da invasão dos espaços políticos pelos órgãos judiciários sob o ponto de vista da incapacidade de seus instrumentos para resolver esse

V. Armango Castelar Pinheiro (org.), Judiciário e Economia no Brasil.

2 Segundo Castelar, uma melhor do Judiciário que o situasse em "padrões de primeiro-mundo" indiretamente faria o Produto Interno Bruto nacional crescer a taxas anuais $25 \%$ mais elevadas. Idem, $\mathrm{p}$. 188.

3 A expressão crítica instrumental, que prefiro utilizar para evitar confusões com aquela que estou chamando de crítica institucional, é usada por Owen M. Fiss em The Forms of Justice, p. 31. Esse texto e todos os demais artigos de Owen M. Fiss citados neste trabalho podem ser encontrados vertidos para o português na seguinte coletânea, organizada por Carlos Alberto de Salles: Owen M. Fiss, Um Novo Processo Civil: Estudos Norte-Americanos sobre Jurisdição, Constituição e Sociedade. 
tipo de disputa. Os órgãos judiciários, diz-se, são formuladores de políticas erráticas e geralmente regressivas, por suas próprias características institucionais, e pelas próprias características do tipo de procedimento que utilizam para desempenhar seu mister. Novamente, crítica e elogio rodam em torno das mesmas notas institucionais que marcam a atuação do órgão judiciário, fazendo, cada qual, leituras próprias dessas suas características fundamentais.

Invertendo a ordem em que esses discursos foram apresentados no parágrafo anterior, começo por referir a linha tradicional pela qual se conduz o elogio à ação política das cortes de justiça, fundado em suas características institucionais mais marcantes (imparcialidade, inércia, decisão conforme o direito e os inputs das partes, necessidade de fundamentar as decisões em princípios racionais - principled decisions - e não em simples preferências, etc.).

Em um trecho de The Forms of Justice, Owen Fiss resume o argumento. ${ }^{4}$ Segundo Fiss, a função jurisdicional, sob o prisma dos instrumentos para seu exercício, é desenhada de tal sorte a forçar os juízes a serem objetivos, impedindo-os de expressar suas opiniões pessoais ou de simplesmente acolher preferências majoritárias encontradas no corpo social. As cortes possuem garantias que asseguram sua independência em relação a pressões de grupos e instituições e suas decisões exigem um diálogo antecedente marcado por quatro qualidades bastante especiais. Nesse diálogo em que os juízes são obrigados a engajar-se (o contraditório judicial), (a) não são eles que escolhem a agenda nem os termos do debate, sendo assim obrigados a resolver questões que talvez de outro modo preferissem ignorar, (b) não são eles que determinam quais são as vozes que deverão ser ouvidas, obrigando-se assim a ouvir todos aqueles que têm interesse direto no conflito, (c) são obrigados a responder, não podendo deixar sem análise um pedido que lhes seja endereçado e (d) suas respostas têm que ser motivadas, e apenas contam como motivos aceitáveis aqueles que não se assentem em preferências pessoais. Por não serem eleitos (Fiss pensa aqui nos juízes federais americanos, em raciocínio válido para o ambiente institucional brasileiro), os juízes não precisam expressar vontades majoritárias, assegurando-se assim sua independência em relação às pressões políticas. Com essas características institucionais, eles podem manter-se "imparciais, distantes e descolados dos litigantes", garantindo-se que a decisão final não seja uma expressão das preferências destes, mas sim a garantia de

4 Cf. Owen M. Fiss, The Forms of Justice, p. 13-14. 
preservação de certos valores que se entenderam relevantes o bastante para que fossem incluídos no texto constitucional. Da soma dessas características resultaria a legitimidade das cortes para funcionarem como "contrapesos" aos órgãos representativos no jogo político do Estado de Direito contemporâneo. ${ }^{5}$

Sob o prisma da critica à capacidade instrumental das cortes de justiça para o trato de conflitos políticos, essas mesmas e exatas características são as que fazem do judiciário um formulador errático de políticas públicas.

Sendo inerte, ele não pode identificar os problemas sociais que estão necessitando mais urgentemente de uma dada política pública. Ele só pode atuar ou deixar de atuar nas

5 "This conception of the judicial function, which sees the judge as trying to give meaning to our constitutional values, expects a lot from judges - maybe too much. The expectation is not founded on a belief in their moral expertise, or on a denial of their humanity. Judges are most assuredly people. They are lawyers, but in terms of personal characteristics they are no different from successful businessmen or politicians. Their capacity to make a special contribution to our social life derives not from any personal traits or knowledge, but from the definition of the office in which they find themselves and through which they exercise power. That office is structured by both ideological and institutional factors that enable and perhaps even force the judge to be objective - not to express his preferences or personal beliefs, or those of the citizenry, as to what is right or just, but constantly to strive for the true meaning of the constitutional value.29 Two aspects of the judicial office give it this special cast: one is the judge's obligation to participate in a dialogue, and the second is his independence. The judge is entitled to exercise power only after he has participated in a dialogue about the meaning of the public values. It is a dialogue with very special qualities: (a) Judges are not in control of their agenda, but are compelled to confront grievances or claims they would otherwise prefer to ignore. (b) Judges do not have full control over whom they must listen to. They are bound by rules requiring them to listen to a broad range of persons or spokesmen. (c) Judges are compelled to speak back, to respond to the grievance or the claim, and to assume individual responsibility for that response. (d) Judges must also justify their decisions. The obligation to justify a decision has given rise to neverending debates as to the proper sources of judicial decisions - text, intentions of the Framers, general structure of the Constitution, ethics, the good of the nation, etc. For the notion of justification, as opposed to exdanation, implies that the reasons supporting a decision be "good" reasons, and this in turn requires norms or rules for determining what counts as a "good" reason. My intention is not to participate in the debate about the rules for justification, but to stress two facts that all seem to agree on as to what might count as a "good" reason. The first is that the reason cannot consist of a preference, be it a preference of the contestants, of the body politic, or of the judge. The statement "I prefer" or "we prefer" in the context of a judicial, rather than a legislative decision, merely constitutes an explanation, not a justification." Second, the reason must somehow transcend the personal, transient beliefs of the judge or the body politic as to what is right or just or what should be done. Something more is required to transform these personal beliefs into values that are worthy of the status "constitutional" and all that it implies - binding on society as a whole, entitled to endure, not forever but long enough to give our public morality an inner coherence, and largely to be enforced by courts. The judge is required to listen and to speak, and to speak in certain ways. He is also required to be independent. This means, for one thing, that he not identify with or in any way be connected to the particular contestants. He must be impartial, distant, and detached from the contestants, thereby increasing the likelihood that his decision will not be an expression of the self-interest (or preferences) of the contestants, which is the antithesis of the right or just decision. The norm of impartiality also requires that the judge be independent from politics, in this instance understood as the process of expressing the preferences of the people. The judge must not view his job as one of registering those preferences. Independence is clearly the norm in the federal system with its promise of life tenure, but is present also in those state systems in which judges are elected. The judge might be vulnerable to the body politic when he stands for election, but that does not determine how he should define his job, or how the body politic should use its power." (Owen M. Fiss, The Forms of Justice, p. 13-14). 
políticas que lhe são submetidas, ainda que elas sejam irrelevantes em relação a outros problemas sociais mais urgentes que tenham ficado à margem da vontade das partes de provocar a intervenção judiciária respectiva. Desdobrando-se a inércia judiciária no dever de adstrição da sentença ao pedido, o judiciário também não pode desenhar a política pública de sorte a acomodar os vários interesses em jogo, exercendo o papel criativo e flexível que se espera de um engenheiro social. Segundo a crítica que estou descrevendo, se a solução propugnada pelo autor não for a melhor o juiz ficará entre a difícil escolha de rejeitá-la, deixando o problema social sem resposta, ou acolhê-la, dando ao mesmo problema uma resposta que sabe ser, ao menos parcialmente, inadequada.

Também as pretensões à objetividade e à decisão com base em direitos e não em preferências das partes podem ser vistas criticamente como deficiências instrumentais para o tratamento de conflitos políticos. Isso porque esses conflitos não se formulam em termos de titulação, mas de desejo, ou, por vezes, necessidade. Os conflitos políticos não se resolvem pela investigação de quem seja o proprietário dos bens em conflito, mas sim pela acomodação das diferentes preferências a respeito desses mesmos bens, as quais são, por sua vez, fundadas em desejos e necessidades, mas não em relações de propriedade.

A pretensão à objetividade da norma jurídica preexistente, centrada em relações de titulação fracas dadas por um texto constitucional extremamente contraditório, torna mais agudo esse problema. Segundo a crítica que estou tentando caricaturizar, faz com que se desmonte a distinção entre esses dois universos da titulação e da necessidade, dizendo àqueles que precisam de saúde que, em razão de sua necessidade, são por isso apenas titulares de um direito à saúde, ainda que esse direito implique políticas redistributivas que por sua vez interferem com direitos alheios, ligados à propriedade de outros bens, os quais são identicamente protegidos pelo texto constitucional e devem, igualmente, ser preservados. ${ }^{6}$

A incapacidade de pensar em termos de preferências, a incapacidade de lidar com a barganha em plano coletivo (não se transacionam direitos indisponíveis, como aqueles de

6 " $[\mathrm{I}] \mathrm{t}$ is all very well to base human rights on material need, but other people may already have property rights over the resources that would have to be used to satisfy these needs" (Cf. Jeremy Waldron, Rights, in Robert Goodin and Philip Pettit (ed.), A companion to contemporary political philosophy, Blackwell, 2005, 579. Note-se que Waldron está, nesse trecho, referindo, mas não endossando, a critica tradicional à caracterização dos direitos de segunda geração como direitos, reportando-se assim, sobretudo, ao pensamento de Nozick.) 
natureza coletiva ou os que envolvem as políticas do Estado, diz o cânone), a necessidade de transformar pontos de vista parciais em direitos que precisam ser ou não ser titulados por quem os afirma, em um jogo de tudo ou nada, a necessidade de adstrição ao caso concreto e a correlativa impossibilidade de extrapolá-lo ou ampliá-lo de sorte a contemplar outras necessidades sociais e, enfim, a incapacidade de gerir a própria agenda e de determinar as próprias soluções fariam do Judiciário, ao fim e ao cabo, um péssimo alocador de recursos. As características instrumentais elogiadas por Fiss agregariam ao Judiciário uma rigidez institucional que faria dele um formulador errático de políticas públicas.

Meu propósito com este trabalho não é o de demonstrar a correção de uma ou outra dessas visões. É apenas o de apresentar em maiores detalhes essa crítica de capacidade instrumental, o de explorar em profundidade seus principais argumentos e o de tentar entender à luz dela certas transformações que parecem ter ocorrido na justiça brasileira ao longo dos anos 1990, sobretudo.

A partir de 1988 (a data é aqui usada muito mais como um marco simbólico, coincidente com a promulgação de um texto constitucional que quis congregar em seus termos abertos toda a sorte de valores conflitantes, todo o tipo de aspirações sociais e de desenvolvimento econômico igualitário, em um contexto de pobreza, dirigismo estatal ineficiente e extrema concentração de renda), qualquer observador atento poderia perceber o curso de um certo movimento, mais ou menos identificável na sociedade brasileira, cujo sintoma mais claro seria a crescente presença dos atores judiciais na mídia, fossem eles juízes, Ministros do Supremo Tribunal Federal, advogados, promotores de justiça, delegados de polícia ou quaisquer outros de semelhantes títulos.

Crescentemente, boa parte das questões nacionais passou a compreender, ainda que incidentalmente, incursões mais ou menos organizadas pelas cortes de justiça. Isso ocorreu com o bloqueio dos saldos de poupança empreendido pelo Plano Collor I e, de forma muito mais intensa e sofisticada, pôde ser visto durante todo o período em que foi implementado o Plano Diretor da Reforma do Estado, por meio da reestruturação dos setores de serviço público e da privatização das empresas estatais.

Esse processo de judicialização da vida pública parece extrapolar, todavia, o contexto nacional. Parece referir-se antes a um movimento global de expansão do papel 
político reservado aos órgãos judiciários, identificável a partir do final da Segunda Guerra Mundial. A primeira parte deste trabalho trata, por isso, de circunscrever esse processo, traçando-lhe as origens históricas recentes e reconhecendo suas peculiaridades nos contextos europeu, americano, latino-americano e brasileiro. Essa parte também apresenta em maiores detalhes o argumento fundamental das críticas referidas acima à inflação de poder que atingiu as cortes de justiça na experiência global recente.

Separada entre essas críticas aquela relativa à capacidade instrumental dos tribunais para lidar com conflitos políticos, dela passa a cuidar a segunda parte do texto. São associadas ao modelo paradigmático de justiça referenciado pela crítica instrumental as noções de comutação e defesa de direitos subjetivos, de modo a demonstrar que essa crítica refere-se sobretudo ao modelo liberal de justiça e de processo judicial, tendo ocorrido, contemporaneamente, mudanças importantes nesse modelo. A essas mudanças, aduz-se, corresponderam alterações importantes no próprio arsenal instrumental da justiça.

A terceira parte do trabalho aborda, portanto, o desenho específico dessas mudanças no contexto brasileiro, sobretudo no âmbito da tutela de interesses difusos e coletivos, buscando compreender essas mudanças à luz de certas dinâmicas que terão sido explicitadas em maiores detalhes nas duas partes anteriores do texto.

A tese que sustento aqui é que várias das alterações recentes no âmbito da justiça e do processo civil brasileiro podem ser compreendidas como reações (ou contra-reações) institucionais à transformação material ocorrida nos tipos de litígio judicializados, que deixam de referir-se apenas a questões de justiça retributiva e passam cada vez mais a envolver litígios de justiça distributiva, passando também de um modelo de adjudicação de direitos para outro de gestão de interesses.

As análises feitas ao longo da primeira, segunda e terceira partes do texto são fundamentalmente analítico-descritivas. Procuram compreender transformações efetivamente ocorridas na dinâmica social e jurídica atribuindo-lhes uma explicação que lhes possa acrescentar um sentido de conjunto. A conclusão do trabalho veicula, contudo, um juízo de valor mais claro quanto à ação concreta da justiça brasileira no campo das políticas públicas, sugerindo um modelo de atuação que poderia contornar as críticas referidas acima, potencializando contribuições positivas que as cortes de justiça parecem poder dar, efetivamente, ao avanço de ideais democráticos. 
Três notas finais, de caráter metodológico, fazem-se necessárias. A primeira diz respeito ao recurso freqüente à comparação da experiência brasileira com a americana. A nítida preferência por essas comparações justificou-se pela imensa semelhança que há entre os arranjos institucionais pertinentes aos dois países (no plano do direito, por exemplo, a unidade de jurisdição e a existência de controle difuso de constitucionalidade e de uma tutela coletiva de interesses difusos bem estruturada). Como se verá adiante, a experiência americana conheceu, com uma antecedência de aproximadamente trinta anos, problemas muitíssimo semelhantes àqueles que se apresentam, agora, à realidade brasileira, tendo sido gerada, até mesmo por isso, uma extensíssima literatura referente à ação política das cortes de justiça, a seus problemas e às suas condicionantes. Não obstante, isso não significa que este seja um trabalho propriamente de direito comparado, elaborado nos limites próprios a esse método de análise.

A outra nota final diz respeito ao uso da primeira pessoa do singular ao longo do trabalho. Esse é um costume ainda pouco comum nos trabalhos acadêmicos brasileiros de direito e, por que não dizer, é um costume que, nesse meio, é as vezes tido como uma má prática, como quebra da etiqueta acadêmica desejável. No entanto, boa parte dos trabalhos acadêmicos brasileiros produzidos no bojo das demais ciências humanas (especialmente na ciência social e na ciência política) faz uso corrente da primeira pessoa do singular, como também ocorre, normalmente, com os trabalhos americanos de direito. Essas últimas opções pareceram ao autor mais desejáveis, por uma série de motivos.

Em primeiro lugar, porque a redação do texto no impessoal torna, muitas vezes, difícil compreender os momentos em que o autor está exprimindo (i) um juízo pessoal e descritivo sobre a realidade, (ii) um juízo pessoal e normativo sobre a realidade, (iii) uma descrição sobre o juízo descritivo da realidade corrente na comunidade acadêmica, ou (iv) uma descrição sobre um certo juizo normativo corrente na comunidade acadêmica. Isso é efeito comum e bem documentado dos expedientes de ocultação do sujeito e apassivação das frases que se tornam necessários para evitar, em todas essas descrições, o uso da primeira pessoa do singular.

Além disso, a forma impessoal pode servir, nos trabalhos acadêmicos, para mascarar o caráter necessariamente pessoal e subjetivo de suas conclusões, manipulando o discurso para fazer com que ele pareça necessário, impessoal, neutro, universal. " $O$ discurso científico (e também o tecnológico) para ser aceito como verdadeiro procura 
parecer que não é um discurso, mas o enunciado das relações necessárias entre as coisas". 7 O expediente é conhecido em filologia como manipulação dialética do discurso. ${ }^{8}$ A opção pela primeira pessoa do singular foi utilizada, portanto, também para contornar esses riscos.

A última observação diz respeito às referências à literatura e demais documentos em língua estrangeira. Por razões de acessibilidade e fluidez, optei por verter para o português todas as citações de fontes estrangeiras feitas no corpo do texto, deixando-as em redação original apenas quando constantes das notas de pé de página. Salvo quando expressamente referido de outra forma, portanto, todas as traduções são de responsabilidade do autor.

7 Cf. Maria Margarida de Andrade, "Estratégias da impessoalidade nos discursos científico e tecnológico", Cadernos do Congresso Nacional de Lingüística e Filologia, Série VIII, n. 5, publicação disponível eletronicamente no endereço http://www.filologia.org.br/viiicnlf/anais/caderno05.html (última consulta em 28 de março de 2005).

8 "Os mecanismos de manipulação dialética produzem mudanças formais no discurso científico, pela utilização de recursos que têm por objetivo torná-lo "neutro", impessoal, tais como o emprego das formas impessoais do verbo, da voz passiva, e determinadas expressões que o despersonalizam. Procura-se, tanto quanto possível, separar o enunciado da instância da enunciação, a fim de que pareça como discurso, não da pessoa, mas como discurso objetivo, que não pertence a ninguém, cujo sujeito seria a ciência, a fazerse por si mesma”. Cf. Maria Margarida de Andrade, id.) 


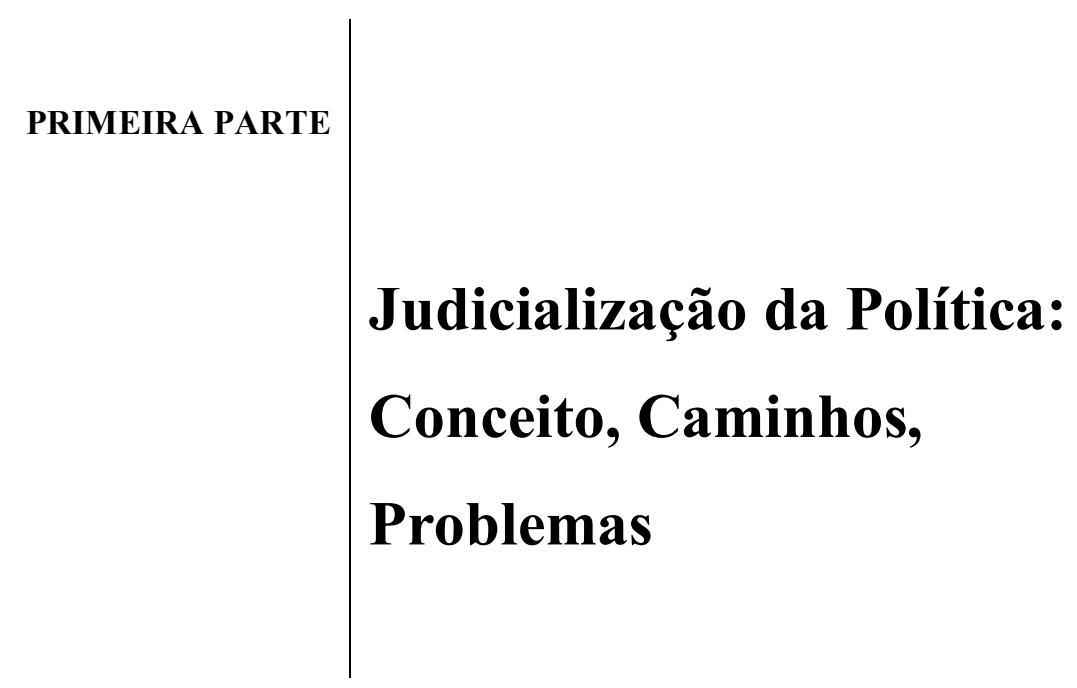

Quais são os quadrantes de atuação legítima do Poder Judiciário? Para o exercício de quais atividades ele é capacitado? Como se delimita o trabalho de aplicação das normas jurídicas por ele, supostamente, desenvolvido? Há criatividade nesse trabalho? Há espaço para preferências pessoais? Há espaço para argumentos ou preferências de ordem política, econômica, utilitarista ou conseqüencialista? Por que todas as demais disciplinas sociais pensam no Poder Judiciário como um ator político, ao passo em que o direito insiste em identificá-lo como uma instância decisória neutra, independente de influências exteriores e, por isso, legitimada ao trabalho de aplicação objetiva das regras jurídicas? Como é que as mesmas características institucionais do Poder Judiciário (independência e isolamento do jogo político representativo) podem ser vistas de forma tão diferente por certos mainstreams de duas disciplinas acadêmicas tão próximas como o direito e a ciência política (a primeira apontando essas características como sendo os próprios fatores de legitimação da ação judicial objetivamente conforme ao direito, e a segunda vendo-as como demonstrações de ilegitimidade de uma ação política contra-majoritária e blindada contra os mais singelos controles sociais $\left.{ }^{9}\right)$ ?

9 Penso, aqui, especialmente, nas vertentes da ciência política americana ou de inspiração americana que, simultaneamente, (i) vêem a regra da maioria como único princípio normativo racional para a construção de uma teoria normativa da política e (ii) colhem do estudo empírico do funcionamento das cortes de justiça conclusões bastante negativas quanto aos resultados, procedimentos e efetividade desse trabalho. Creio que ambas essas aproximações estejam na base de boa parte do pensamento de Robert Dahl, que acabou por influenciar toda uma geração de cientistas políticos nos Estados Unidos (v., sobre um e outro pontos referidos acima, Robert A. Dahl, A Preface To Democratic Theory, e Robert A. Dahl, DecisonMaking in a Democracy: The Supreme Court as a National Policy-Maker). Outros exemplos contundentes da segunda aproximação mencionada acima são os trabalhos empíricos de Gerald Rosenberg, The Hollow Hope: Can Courts Bring About Social Change? (procurando demonstrar que, em 
Essas questões têm a paradoxal peculiaridade de manterem-se na ordem do dia ao menos durante os últimos duzentos e poucos anos. São questões atuais e pertinentes, prioritárias na agenda dos estudos jurídicos e de outras disciplinas sociais neste início de século, mas que circundam as preocupações dos cientistas políticos, dos juristas e de outros acadêmicos, de uma forma ou de outra, desde o final do século XVIII ${ }^{10}$. Historicamente, a origem das perplexidades que se escondem por trás dessas perguntas remonta ao processo de diferenciação do direito público e do direito privado, por meio do qual se forjou a distinção hoje corrente entre as idéias de direito e política. ${ }^{11}$ Mas por que esse tema alcança, hoje, tamanho destaque? Em parte, um dos objetivos principais desta primeira sessão do trabalho consiste em identificar essas razões, definindo também, da melhor maneira possível, o problema que se esconde por trás dessas questões.

Esse problema, como enuncia o título desta parte inicial, vem sendo identificado contemporaneamente pela idéia de judicialização da política. Essa expressão, por sua vez,

toda a história dos Estados Unidos, a ação da Suprema Corte não foi responsável, ela mesma, por qualquer avanço em termos de igualdade social ou proteção de direitos humanos), e de Jeffrey A. Segal e Harold J. Spaeth The Supreme Court And The Attitudinal Model Revisited (sustentando que as posições assumidas pelos juízes da Suprema Corte americana em seus votos são explicáveis empiricamente apenas e exclusivamente com base nas respectivas preferências políticas, i.e., com base em suas posições ideológicas pessoais a respeito de questões como direitos humanos e ação regulatória do executivo, em um contexto no qual aspectos jurídicos como o respeito a precedentes jurisprudenciais, ao próprio texto da lei, ou a critérios de interpretação histórica, sistemática ou semelhantes desempenham pouco ou nenhum papel efetivo). De outro lado, quando confronto esse tipo de aproximação com aquilo que chamo de mainstream da ciência jurídica, penso sobretudo nas várias defesas das noções de constitucionalismo e de justiça constitucional, que estão na base desse mainstream, e que dependem umbilicalmente da existência de um Poder Judiciário que se legitima pelas características expostas acima. Alguns exemplos paradigmáticos desse tipo de pensamento, ainda que bastante diferentes entre si, podem ser encontrados em Mauro Cappelletti, Juízes Legisladores?, Cândido R. Dinamarco, A Instrumentalidade do Processo, ou em Alexander Bickel, The Least Dangerous Branch: The Supreme Court at the Bar of Politics, entre tantos outros trabalhos. Mas é claro que há inúmeras visões diferentes dessas tanto nos domínios da ciência política quando do direito. Exemplos respectivos disso podem ser encontrados, v.g., em toda a literatura de ciência política influenciada pelos papéis federalistas (da qual Democracy in América, de Tocqueville, talvez seja o exemplo mais antigo) e, de outro lado, na tradição jurídica francesa avessa a qualquer noção de controle ordinário de constitucionalidade (v., por exemplo, Edouard Lambert, Le gouvernement des juges et la lutte contre la législation sociale aux États-Unis: l'expérience américaine du contrôle judiciaire de la constitutionnalité des lois), ou mesmo na literatura jurídica americana contrária, em maior ou menor medida, ao chamado judicial activism (v., sobretudo pelas referências bibliográficas, John Hart Ely, Democracy and distrust).

10 As revoluções liberais do final do século XVIII e os arranjos político-institucionais que se seguiram a elas tiveram, sem dúvida, essas questões em foco. Soluções bastante diferentes foram encontradas, no entanto, por cada um dos dois exemplos mais importantes desse movimento histórico: o processo de independência das colônias americanas e a revolução francesa. Enquanto o modelo Madisoniano de democracia gerou, nos Estados Unidos, a opção por um constitucionalismo baseado em um sistema de checks and balances, produzindo um judiciário forte como resultado da Convenção da Filadélfia, a revolução burguesa na França acabou por gerar, a seu turno, um judiciário fraco, centrando seu arranjo institucional na noção de separação de poderes e na idéia de supremacia parlamentar.

11 Esse processo é examinado com mais cuidado na segunda parte deste trabalho. 
acaba sendo utilizada para designar uma série enorme de fenômenos, muitos dos quais bastante diferentes entre si. Por exemplo, estão envolvidos nessa idéia problemas como (i) a crescente interferência judicial em políticas públicas formuladas pelo Executivo, (ii) a revisão de textos legais com fundamento em mecanismos diversos de controle de constitucionalidade das leis, (iii) a formulação de demandas buscando a efetivação judicial de direitos humanos de cunho social e econômico, inseridos em Constituições socialdemocratas e tratados internacionais, (iv) a introdução de uma racionalidade políticoideológica no discurso judicial, permeada por noções de justiça social ou por outras noções congêneres, (v) a organização de certas categorias ligadas aos setores judiciários em órgãos classistas, (vi) a adoção de procedimentos de tipo judicial em órgãos executivos e legislativos, (vii) a criação de instâncias supra-nacionais de resolução de conflitos e produção de políticas públicas, como é o caso do Tribunal de Justiça das Comunidades Européias, ou das Corte de Strasburgo e (em menor medida) San Jose da Costa Rica, etc.

Em contrapartida ao caráter ancestral de boa parte desses temas (ao menos o do controle de constitucionalidade das leis remonta, pelo menos, aos idos de $1803^{12}$ ), o termo "judicialização da política", ele mesmo, é de formulação bem mais recente, constando ter sido utilizado pela primeira vez, com o objetivo de descrever toda essa variada gama de fenômenos, nos papers apresentados ao seminário homônimo realizado em junho de 1992 em Forlí, Itália, pelo Centro di Studi sull'Ordinamento Giudiziario di Bologna. ${ }^{13}$

Segundo Vallinder, a essa idéia de judicialização da política corresponderiam, grosso modo, duas vertentes distintas mas inter-relacionadas de um mesmo movimento contemporâneo de expansão global do Poder Judiciário: (i) o processo de "transferência" de certas prerrogativas decisórias dos órgãos executivos e legislativos para os órgãos judiciários, ou, em outras palavras, o processo de ampliação da capacidade de criação de regras jurídicas por parte das cortes de justiça, às expensas das prerrogativas detidas pelos órgãos políticos tradicionais, cuja legitimidade deriva da representação popular, e (ii) o

12 Essa é a data em que foi publicada a famosa decisão da Suprema Corte americana proferida no caso Marbury v. Madison (5 US 135). Sobre o contexto em que a decisão foi proferida e sua importância para o desenvolvimento posterior do sistema americano de controle de constitucionalidade, v. meus comentários lançados no item I, adiante.

13 V. http://www.spbo.unibo.it/bologna/dipartim/dosp/cesrog.htm. Vários desses papers foram subseqüentemente publicados em uma edição especial da International Political Science Review (vol. 15, n. 2, abril de 1994 - ed. Torbjörn Vallinder), sendo depois coligidos em um volume também homônimo editado em 1995 por C. Neal Tate (professor de ciência política na University of North Texas) e Torbjörn Vallinder (professor do departamento de ciência política da Universidade de Lund, Suécia) (C. Neal Tate e Torbjörn Vallinder, The global expansion of Judicial Power, p. vii-viii). 
concomitante processo de absorção dos métodos de decisão próprios aos órgãos judiciários por parte dos órgãos legislativos e executivos. ${ }^{14}$

Quanto ao primeiro aspecto indicado acima, é preciso destacar que esse processo de "transferência" de prerrogativas dos parlamentos e dos órgãos executivos às cortes de justiça não se dá sem um certo desencontro de paradigmas institucionais. Isso porque, como anota ainda Vallinder, "nas democracias, primariamente em suas assembléias eleitas pelo povo, os processos de tomada de decisão são baseados no princípio da maioria e em um debate livre e público entre iguais" ${ }^{\text {"15 }}$. Naturalmente, esse não é o modo de produção de decisões utilizado pelas cortes de justiça.

A ação dessas cortes implicaria, sobretudo, as seguintes características institucionais: (a) pessoal especializado (juízes), normalmente com treinamento legal, (b) a resolução de conflitos entre duas partes de modo regular e imperativo, de acordo com (c) regras preestabelecidas, envolvendo, portanto (d) o estabelecimento dos fatos do caso e o sopesamento dos argumentos das partes em conflito, com (e) efeitos prospectivos para casos similares no futuro. ${ }^{16}$

Vallinder desenha um quadro exemplificativo atinente às diferenças entre os modos judicial e político de resolução de conflitos. Esse quadro segue reproduzido abaixo (Quadro 1). ${ }^{17}$

Se ao modo de operação típico das cortes de justiça parece corresponder a solução de litígios interindividuais, no plano da teoria política a função típica desses órgãos seria a de proteger os cidadãos contra abusos do Estado, ou seja, garantir a efetivação de certas liberdades, de cunho negativo, garantidas constitucionalmente. De outro lado, a função típica dos corpos parlamentares seria a de definir direitos e obrigações. Conforme aponta Vallinder, "pode-se dizer esquematicamente que a judicialização da política significa a majoração do primeiro princípio em detrimento do segundo"18.

\footnotetext{
14 Cf. Tobjörn Vallinder, When the Courts Go Marching In, p. 13.

15 Idem, ibidem.

16 Idem. p. 14.

17 V., também, Lon Fuller, The Forms and Limits of Adjudication.

18 Ob. Cit. p.15.
} 
(Quadro 01)

\begin{tabular}{|c|c|c|}
\hline \multicolumn{3}{|c|}{ Comparação entre uma Corte e um Corpo Legislativo } \\
\hline Características & Corte & Corpo Legislativo \\
\hline Atores & $\begin{array}{l}\text { duas partes e um terceiro } \\
\text { participante (o juiz) }\end{array}$ & várias partes \\
\hline Métodos de trabalho & $\begin{array}{l}\text { audiências públicas } \\
\text { sopesamento de argumentos }\end{array}$ & $\begin{array}{l}\text { barganha, frequentemente a portas } \\
\text { fechadas, compromissos, trocas de } \\
\text { favores }\end{array}$ \\
\hline $\begin{array}{l}\text { Regras básicas de tomada de } \\
\text { decisão }\end{array}$ & $\begin{array}{l}\text { decisão tomada por um juiz } \\
\text { imparcial }\end{array}$ & princípio majoritário \\
\hline Resultados & $\begin{array}{l}\text { resolução de casos individuais } \\
\text { (mas com a criação de } \\
\text { precedentes, especialmente no } \\
\text { controle de constitucionalidade) }\end{array}$ & $\begin{array}{l}\text { regras gerais (leis, orçamentos), } \\
\text { definição de políticas públicas }\end{array}$ \\
\hline Implicações & $\begin{array}{l}\text { determinação dos fatos (o que } \\
\text { aconteceu) e da regra a ser } \\
\text { aplicada (o que deve ser } \\
\text { aplicado), "a única solução } \\
\text { correta" }\end{array}$ & $\begin{array}{l}\text { alocação de valores } \\
\text { (frequentemente econômicos), "a } \\
\text { solução politicamente possível" }\end{array}$ \\
\hline
\end{tabular}

Uma das formas pelas quais o processo se desenvolve é, claramente, o controle judicial de atos do Poder Executivo e Legislativo. Se esse controle se dá por meio da aplicação de uma carta de direitos particularmente aberta, seu escopo amplia-se consideravelmente. Vallinder entende ser essa uma forma de "judicialização da política "vinda de fora",19. Outras formas de judicialização "vindas de dentro" corresponderiam à “introdução ou expansão de pessoal ou métodos de trabalho próprios à esfera judicial no setor administrativo". ${ }^{20}$

De fato, a história recente das reformas administrativas mostra uma alteração significativa no modo de operação da administração pública, que incorpora, gradativamente, mecanismos de ação judicial e parlamentar.

Os últimos relacionam-se sobretudo às exigências de consultas e audiências públicas na atividade regulatória, sobretudo de caráter normativo. $\mathrm{Na}$ experiência brasileira, um exemplo claro desse tipo de tendência pode ser encontrado na chamada Lei Geral de Telecomunicações, que diz ser de competência da Agência Nacional de

\footnotetext{
19 Idem. p. 16.
}

20 Idem, ibidem. 
Telecomunicações a prática de diversos atos normativos, condicionando sua validade, todavia, à submissão prévia das minutas desses atos à consulta pública, "formalizada por publicação no Diário Oficial da União, devendo as críticas e sugestões merecer exame e permanecer à disposição do público na Biblioteca". ${ }^{21}$

Mas é a adoção de mecanismos de ação judicial pela administração que parece chamar mais a atenção na história recente dos ordenamentos nacionais. No plano institucional, um marco inicial importante coincide com a promulgação, em 1946, do Administrative Procedure Act, nos Estados Unidos. Reformas legislativas atinentes à reestruturação de procedimentos administrativos, com vistas a dotá-los de garantias de participação de cunho quase judicial são empregadas também na Espanha, em 1958, na Alemanha, em 1976, na Itália, em 1990, em Portugal, em 1992, e no Brasil, sobretudo com a edição da Lei n. 9.784, de 29 de janeiro de 1999. Esse processo já foi chamado de "processualização do direito administrativo" 22 e, para Vallinder, significa um caminho, dentro da Administração Pública, em direção a "mais adjudicação, menos administração",23.

Esse caminho em direção à processualização do direito administrativo, à judicialização "vinda de dentro", como sugere Vallinder, corre paralelo ao desenvolvimento da judicialização "vinda de fora", ocorrida sobretudo no período posterior à Segunda Guerra Mundial, quando o papel das cortes e dos juízes se expande consideravelmente.

Nesse sentido, trata-se de um movimento que acompanha, de certo modo, a própria burocratização do Estado Social, funcionando, como definiu Cappelletti, como um "contrapeso" ao agigantamento do Poder Executivo e à conseqüente perda de espaço político das casas legislativas, no curso do chamado welfare state. ${ }^{24}$

Sob o ponto de vista instrumental, esse movimento caminha paralela e conjuntamente a diversas outras transformações estratégicas ocorridas no coração do direito do Estado Social de Direito, por meio das quais foram positivados, nos planos

21 Cf. Lei n. 9.472 de 16 de julho de 1997, artigo 42.

22 Cf. Odete Medauar, A Processualidade no Direito Administrativo.

23 Ob. Cit. p. 16.

24 V. Mauro Cappelletti. Juizes Legisladores?, p. 50. 
internacional, comunitário ou local, direitos humanos de variada ordem, incluindo os chamados direitos de segunda e terceira geração ou "sociais e de solidariedade", tais como os direitos humanos de natureza econômica e social tratados no Pacto Internacional de Direitos Econômicos, Sociais e Culturais (1966), ou mesmo como os direitos ligados à proteção do mercado de consumo, do meio ambiente, ou de outros interesses de natureza difusa ou coletiva, objeto de inúmeras inovações legislativas nos planos nacional ${ }^{25}$ e internacional $^{26}$ e, também, objeto de variadas diretivas da Comunidade Européia, produzidas na segunda metade do século passado.

O processo de "judicialização da política" acompanha, também, o movimento de crescente indeterminação normativa que marca a produção do direito no período do Estado Social. $^{27}$

Essa crescente indeterminação normativa identifica-se com o uso de expressões abertas pelo direito e com a preferência do legislador pelo uso de princípios genéricos ao invés de regras particulares, diretas e específicas, até como conseqüência da necessidade, sentida pelos parlamentos, de outorgar níveis cada vez maiores de discricionariedade ${ }^{28}$ aos órgãos do Poder Executivo, responsáveis pelo desenvolvimento das políticas welfaristas.

A abertura maior dessas normas forneceu os instrumentos para uma maior atuação do Judiciário frente aos demais órgãos e Poderes do Estado, assim como também ocorreu com os mecanismos de controle de constitucionalidade que foram previstos, de forma mais ou menos uniforme, pela maior parte das legislações européias.

25 Cf. , v.g., o Código de Defesa do Consumidor (Lei n. 8.078, de 11 de setembro de 1990), a Lei da Ação Civil Pública (Lei n. 7.347, de 24 de julho de 1985) ou a Lei n. 6.938, de 31 de agosto de 1981, que dispôs sobre a Política Nacional do Meio Ambiente.

26 Nos Estados Unidos, cf., v.g., o National Environmental Policy Act (NEPA); 42 U.S.C. 4321-4347 (1969), ou o Consumer Credit Protection Act (CCPA); 15 U.S.C. 1601 (1968).

27 V. a respeito Marcos Paulo Verissimo, Controle judicial da atividade normativa das agências de regulação brasileiras.

28 A idéia de discricionariedade têm muitos sentidos para o direito. V., a respeito, Ronald Dworkin, Taking Rights Seriously, p. 31-39. V., tb., Marcos Paulo Verissimo, Controle judicial da atividade normativa das agências de regulação brasileiras. No texto acima, a expressão é indicada para designar o grau maior de liberdade que é outorgado ao Executivo, pela legislação do Estado Social, para a formulação concreta de políticas públicas que possam vir a atingir, ulteriormente, os objetivos normativos estabelecidos de forma principiológica por essa mesma legislação. Aqui, não pretendo referir, com esse uso da palavra discricionariedade, qualquer juízo específico quanto à possibilidade de controle dessa ação normativa particular pelo Poder Judiciário, não obstante a associação, comumente feita pelo direito brasileiro, entre as idéias de discricionariedade administrativa e impossibilidade de controle judicial. Sobre esse tema, $\mathrm{v}$. Marcos Paulo Verissimo, idem. 
Mas por que, afinal, passam a ser previstos esses mecanismos de controle de constitucionalidade na maior parte das legislações européias do pós-guerras? Quais seriam as explicações de cunho jurídico, social e político para a inserção desses instrumentos de controle do poder político nos ordenamentos jurídicos nacionais? E, além disso - talvez até mais importante que isso - quais teriam sido as condições institucionais que se fizeram presentes para que fosse possível (talvez necessário) ao Judiciário desempenhar um papel político cada vez mais importante nas sociedades contemporâneas, fazendo uso, justamente, desses instrumentos legais?

As explicações para esse fenômeno são várias e talvez nem todas elas interessem aos propósitos mais restritos deste trabalho, mas uma primeira impressão a respeito do problema parece mais ou menos intuitiva. Nesse sentido, não parece despropositado imaginar que o horror de duas guerras tenha gerado certo clamor pelo aprofundamento de alguns princípios inerentes ao Estado de Direito (clamor por rule of law), gerando demandas pela adoção de princípios próprios a um constitucionalismo do tipo checks and balances. De outro lado, não é despropositado pensar que a inserção desse movimento em um contexto de crescente welfarismo tenha moldado as novas Constituições européias em larga medida à inspiração do modelo Weimariano $^{29}$ de Constituição. Em um ou outro contexto (checks and balances e proteção dos direitos humanos, inclusive os de cunho social), o papel reservado às cortes de justiça por esse determinado constitucionalismo é evidentemente relevante. Elas, as cortes de justiça, consistem nos órgãos que tradicionalmente são chamados a aplicar e interpretar as regras próprias a esse tipo de Constituição, órgãos esses ligados, direta ou indiretamente, à estrutura do Poder Judiciário (no caso europeu, cortes constitucionais inspiradas pelo modelo austríaco, no caso

29 A Constituição alemã de 1919 (a “Constituição de Weimar”) tornou-se, ao final da segunda guerra mundial, verdadeiro modelo de inspiração para as constituições dos estados social-democratas europeus emergentes. Há, é verdade, um certo paradoxo nisso, na medida em que essa mesma Constituição não se mostrou capaz, na própria Alemanha, de conter os avanços autoritários do partido Nacional Socialista. No entanto, é duvidoso imaginar que qualquer arranjo político institucional poderia ter contido, naquele contexto histórico específico, o avanço do nazismo na Alemanha. De uma forma ou de outra, a Constituição de Weimar foi primeira constituição (na verdade, a segunda, se considerada a Constituição Mexicana de 1917) a incorporar aos tradicionais princípios de constituição do Estado todo um rol de direitos cunho econômico e social, que depois seriam transportados para a esfera internacional por meio da International Covenant on Economic, Social and Cultural Rights, de 1966, em vigor a partir de janeiro de 1976. V., a respeito, Fábio Konder Comparato, Afirmação histórica dos direitos humanos, passim. 
americano, quaisquer cortes de justiça, com papel destacado para os órgãos de cúpula do Poder Judiciário). ${ }^{30}$

Essa rápida e intuitiva explicação dá conta, contudo, de uma parte pequena da questão. Se correspondente de fato à realidade, ela pode talvez responder por um dos motivos que teria levado à expansão do controle de constitucionalidade na Europa. Contudo, o chamado movimento de judicialização da política é bem mais amplo. É mundial e abrange uma série de outros fenômenos relacionados, mas muitos deles distintos do simples controle de constitucionalidade das leis. As críticas feitas a esse mesmo processo (extremamente relevantes aos propósitos deste trabalho) também transitam por problemas mais abrangentes.

Algumas das explicações sugeridas acima são confirmadas por Vallinder. Para o autor, "um fator importante foi o crescimento na década de 1930 dos regimes totalitários na Europa e sua horrível investida contra os direitos dos cidadãos, especialmente durante a guerra. Depois da guerra, contra esse contexto, democratas em toda a parte tiveram que fazer a si mesmos algumas perguntas cruciais: Como isso pode ter acontecido? Como se pode prever a recorrência desse tipo de coisa? Em outras palavras: Como podemos proteger os direitos dos cidadãos no futuro?”31 Na Alemanha, a reação se dá logo em 1949, quando o Grundgesetz é promulgado, "contendo uma extensa carta de direitos, uma corte constitucional e a previsão de controle judicial". ${ }^{32}$ Mas haveria também outros fatores importantes, como o dirigismo estatal sobre a economia, o crescimento do sistema capitalista e sua crescente tendência à oligopolização, por exemplo. Nesse contexto, o judiciário passa a abarcar entre suas funções a de "defender o indivíduo dos oligopolistas e dos oligarcas que ameaçam sua liberdade". 33

Outro fator de contexto estaria, finalmente, na retomada das teorias do direito natural durante a segunda metade do século XX, até então subjugadas "por uma filosofia

30 Digo direta ou indiretamente ligadas à estrutura do Poder Judiciário porque o Conseil Constitutionnel francês, que tem, no mais, boa parte das feições de uma corte constitucional, não é ligado diretamente à estrutura do Poder Judiciário, tendo, além disso, um âmbito de atuação bem mais restrito e incorporado, de certa forma, ao próprio processo legislativo. V., a esse respeito, as considerações feitas com mais vagar no item III, adiante.

31 Ob. Cit. p. 19.

32 Idem. p. 20.

33 Idem. p. 21. (Vallinder está, aqui, citando Crossman). 
mais ou menos Benthamista, utilitarista, emulando Hume e portanto adotando posturas extremamente críticas em relação ao direito natural". ${ }^{34}$

Finalmente, Vallinder aponta ainda uma explicação de cunho algo imperialista, ligada ao assombroso crescimento do domínio americano sobre a economia e a geopolítica mundial, ao qual seguiu-se, diretamente, uma tendência à "exportação" do modelo político americano para outros países, nele incluído, naturalmente, o importante papel reservado às cortes de justiça, ${ }^{35}$ sobretudo no período da chamada Warren Court (1953-1969), cujo trabalho "melhorou fortemente a reputação da corte e da idéia de controle judicial, dentro e fora dos Estados Unidos". 36

Nos itens seguintes, procuro dar conta dos principais problemas envolvidos no movimento de expansão global dos domínios de ação do Poder Judiciário, tentando fornecer, também, uma moldura geral dentro da qual esse movimento possa ser concebido. Para tanto, tento traçar, primeiro, uma caracterização dos dois paradigmas principais de ação judiciária desenvolvidos pelo direito das nações ocidentais no final do século XVIII, quais sejam, o americano e o francês, para mostrar como esses paradigmas endereçam, cada qual, visões profundamente distintas a respeito do papel político que deveria ser reservado às cortes de justiça, mostrando, também, como essas visões foram, cada qual, invariavelmente influenciadas pelos momentos histórico e político respectivos. Depois disso, procuro propor um panorama geral dentro do qual possa ser compreendido o movimento de expansão do Poder Judiciário em três experiências recentes distintas: (i) a americana, (ii) a européia, e (iii) a latino americana. Em seguida, procuro mostrar como se coloca o processo de judicialização da política no Brasil, focando a análise respectiva, tanto quanto possível, nos dados empíricos disponíveis.

Uma vez desenhado esse panorama geral, procuro finalmente expor as críticas mais comuns lançadas ao processo de expansão do Judiciário sobre os demais poderes do Estado (críticas fundadas em problemas de legitimidade, de construção institucional e capacidade instrumental). A análise mais detida da crítica ligada à incapacidade instrumental do judiciário para lidar com questões de fundo político conduzirá às discussões subseqüentes, travadas na segunda e terceira partes deste trabalho.

\footnotetext{
34 Idem, ibidem.

35 Idem. p. 22

36 Idem, ibidem.
} 


\section{MEDO DA MAIORIA E MEDO DA MINORIA: DOIS PARADIGMAS PARA A ATUAÇÃO DAS CORTES DE JUSTIÇA}

Compreender o papel importante reservado pelo constitucionalismo americano para as cortes de justiça implica analisar, sobretudo, dois eventos igualmente relevantes na história norte-americana: (i) o debate político travado por ocasião da aprovação e ratificação da Constituição de 1787 , em larga medida reproduzido nos papéis federalistas ${ }^{37}$ e anti-federalistas ${ }^{38}$ e (ii) a decisão proferida dezesseis anos mais tarde pela Suprema Corte americana, no caso Marbury v. Madison ${ }^{39}$, julgado em 1803.

Quanto ao primeiro tema, não é necessário dizer demais. É bastante conhecida a importância dada pelos Federalistas (em geral, oligarcas proprietários de grandes glebas de terra, ou grandes comerciantes do nordeste americano) à existência de um Poder Judiciário forte, que pudesse funcionar como freio, ou contrapeso às instituições majoritárias, cujo funcionamento traria intrínseco o risco de "tiranização" das minorias por parte das maiorias. Robert Dahl chama esse modelo de democracia, baseado na figura de uma corte de justiça com poderes de judicial review, de "Democracia Madisoniana". 40

É certo, como se verá abaixo, que o poder de revisão judicial das leis não foi expresso claramente na Constituição Americana. A concepção desse poder, no entanto, já circundou os debates que caracterizaram a Convenção da Filadélfia, que durou de maio a setembro de 1787 (a Constituição americana foi assinada em 17 de setembro). Mas os debates mais intensos seriam travados no processo subseqüente de ratificação da Constituição, que precisaria ser aceita por ao menos nove das treze ex-colônias para entrar em vigor $^{41}$.

A campanha em favor da ratificação tomou os jornais. Tanto o Partido Federalista quanto o Partido Anti-Federalista expuseram a público suas posições. Pelos Federalistas

7 V. Alexander Hamilton et al., The Federalist Papers.

38 V. Ralph Ketcham (ed.), The Anti-Federalist Papers and the Constitutional Convention Debates.

395 US 135 (1803).

40 Robert A. Dahl, A Preface to Democratic Theory, p. 4

41 O nono Estado a ratificar a Convenção (New Hampshire) o faz em 2 de julho de 1788. Dois meses depois, com a adesão da Virgínia e de Nova Iorque, as treze ex-colônias o terão ratificado. 
falaram James Madison, John Jay e Alexander Hamilton. Publicaram seus textos entre outubro de 1787 e maio de 1788, no Independent Journal, no New-York Packet e no Daily Advertiser. Como sabido, os textos passaram a ser conhecidos como "papéis federalistas".

O Federalista n. 10 expressa a noção de medo das maiorias que caracteriza o arranjo constitucional defendido por Madison. Segundo o autor, "entre as inúmeras vantagens prometidas por uma União Federal bem construída, nenhuma merece ser mais cuidadosamente desenvolvida senão sua tendência de quebrar e controlar a violência das facções", entendidas como "um certo número de cidadãos, quer consistindo em uma maioria ou em uma minoria, que estão reunidos e motivados por algum impulso comum de paixão, ou de interesse, contrário aos direitos dos demais cidadãos, ou ao interesse permanente e agregado da comunidade".

Segundo Madison, haveria apenas dois modos de curar os desvios de comportamento próprios às facções. $\mathrm{O}$ primeiro consiste em remover suas causas. $\mathrm{O}$ segundo, em controlar seus efeitos.

É possível remover as causas que levam à formação das facções por dois modos, ambos, todavia, igualmente inaceitáveis. O primeiro consiste em acabar com a liberdade que é essencial à sua existência. $\mathrm{O}$ segundo resolve-se em atribuir a todos os cidadãos as mesmas opiniões, as mesmas paixões, os mesmos interesses, evitando-se assim o dissenso.

A única forma de afastar os perigos representados pelas facções é, portanto, controlar os efeitos de sua existência. Quando a facção consiste em uma minoria, isso pode ser facilmente alcançado pelo princípio republicano, consubstanciado na regra da maioria. O problema para Madison está, pois, nas hipóteses em que a facção consiste na própria maioria. Quando isso acontece, “a forma popular de governo... permite à maioria que sacrifique sob o julgo regulador de suas paixões e interesses tanto o bem comum quanto os direitos dos outros cidadãos".

Para Madison, a única forma de evitar a tirania das facções majoritárias é, nesse caso, impedir a formação de paixões ou interesses comuns a um número tal de pessoas que possa constituir-se em uma maioria, o que é evidentemente impraticável, ou então "a maioria, tendo tais paixões e interesses comuns, deve ser tornada, por seu número e situação local, incapaz de levar a efeito esquemas de opressão". 
Começa a nascer assim o princípio contra-majoritário na experiência americana: "[d] esse ponto de vista, deve-se concluir que uma democracia pura, compreendida como uma sociedade consistente de um pequeno número de cidadãos, que se reúnem e administram o governo pessoalmente, não consegue engendrar remédio algum contra os desgovernos das facções". Qual é o sistema de governo que pode fazê-lo? Apenas uma "república", na qual algum esquema de representação toma o lugar do governo direto pelos cidadãos. Neste esquema, as diferentes opiniões podem ser interpretadas por "um corpo escolhido de cidadãos, cuja sabedoria pode melhor distinguir o verdadeiro interesse de seu país, e cujo patriotismo e amor à justiça serão menos provavelmente sacrificados em favor de considerações parciais e temporárias". ${ }^{42}$

A virtude desses representantes garante-se também pelo fato de não reunirem todos os poderes da república em si, dividindo-os entre os ramos legislativo, executivo e judiciário do Estado. Garante-se, ainda, pela realização de eleições periódicas. Mas estas, por si sós, não são suficientes a garantir que o poder não seja utilizado de forma tirânica. ${ }^{43}$ A melhor garantia para tanto é a própria Constituição e, eis aqui o caráter distintivo do sistema americano, a existência de um judiciário independente, capaz de aplicá-la e interpretá-la.

O panfleto federalista de n. 78, escrito por Hamilton em junho de 1788, tendo por mote o "Órgão Judiciário", dá conta do tema, na forma seguinte:

\footnotetext{
"A completa independência das cortes de justiça é particularmente essencial em uma Constituição limitada. Por Constituição limitada entendo aquela que contém certas exceções bem especificadas à autoridade do legislativo, como, por exemplo, a de que ele não poderá editar leis de exceção, leis com efeitos retroativos e assim por diante. Limitações dessa espécie não podem ser preservadas na prática de outra forma que não por meio de uma corte de justiça,
}

42 Um extraordinário panorama da chamada dificuldade contra-majoritária é oferecido por Barry Friedman em cinco artigos publicados sob o título comum de The History of the Countermajoritarian Difficulty. O primeiro (The road to judicial supremacy) foi publicado em 73 N.Y.U. L. Rev. 333 (1998). O segundo (Reconstruction's Political Court), em 91 Geo. LJ 1 (2002). O terceiro (The Lesson of Lochner), em 76 N.Y.U. L. Rev. 1383 (2001). O quarto (Law’s politics), em 148 U. Pa. L. Rev. 971 (1999-2000). O quinto (Birth of an Academic Obsession) em 112 Yale L.J. 153 (2002-2003). Segundo aponta Friedman no primeiro texto citado, "The "countermajoritarian difficulty" has been the central obsession of modern constitutional scholarship.". É também dele a constatação de que "After all, the Framers appear to have constructed the judiciary in deliberately countermajoritarian fashon" (idem, p. 344)

43 V. O Federalista n. 49. Ver também Robert A. Dahl, A preface..., p. 14. 
cujo dever deve ser declarar nulos todos os atos contrários ao teor manifesto da Constituição. Sem isso, toda a reserva de direitos ou privilégios particulares resultaria em nada" ${ }^{24}$.

Neste panfleto e nos de número 79, 80, 81, 82 e 83 Hamilton faz a defesa do modelo de órgão judiciário definido pela Convenção da Filadélfia, incluindo as principais características que, incorporadas, v.g., à Constituição brasileira de 1988, dão o feitio institucional básico a esse órgão também no Brasil dos dias atuais. Essas características são, em resumo, vitaliciedade (tenure), irredutibilidade de vencimentos (a power over a man's subsistence amounts to a power over his will), divisão em vários órgãos com competências específicas, independência funcional, impossibilidade de perda do cargo com base em fatos ligados ao próprio exercício da judicatura e, finalmente, poder de revisão da constitucionalidade das leis e atos executivos pelo próprio órgão judiciário independente.

Esta última é, sem dúvida, a característica marcante. No início do Federalista n. 81, Hamilton dá conta de fazer sua defesa contra os ataques que lhe eram desferidos pelos Anti-Federalistas, antecipando, mais uma vez, as eternas discussões que se seguiriam em torno da tal "dificuldade contra-majoritária":

\begin{abstract}
“Os argumentos, ou melhor, sugestões, sobre os quais esse ataque é fundado, vão nesta linha: 'A autoridade da Suprema Corte proposta para os Estados Unidos, que se quer formar como órgão separado e independente, será superior àquela do parlamento. O poder de interpretar as leis de acordo com o espírito da Constituição irá permitir à corte que as molde e transforme em qualquer forma que ela possa entender apropriada, especialmente na medida em que suas decisões não irão estar de maneira alguma sujeitas à revisão ou correção por parte do órgão legislativo. Isto não tem precedentes e é perigoso. Na Inglaterra, o Poder Judiciário, em última instância, reside na House of Lords, que é um ramo do legislativo; e essa parte do governo britânico tem sido imitada pelas Constituições dos Estados em geral. O parlamento da GrãBretanha e os parlamentos de diversos Estados podem a qualquer momento retificar, por meio da lei, as decisões excepcionáveis de suas respectivas cortes. Mas os erros e usurpações da Suprema Corte dos Estados Unidos serão incontroláveis e irremediáveis'. Este, como demonstrarei, se mostrará de uma só vez como um raciocínio falso efetivado a partir de um fato mal compreendido.
\end{abstract}

44 O famoso texto, que se transformou no cânone do constitucionalismo de feição americana, é assim no original: "The complete independence of the courts of justice is peculiarly essential in a limited Constitution. By a limited Constitution, I understand one which contains certain specified exceptions to the legislative authority; such, for instance, as that it shall pass no bills of attainder, no ex post facto laws, and the like. Limitations of this kind can be preserved in practice no other way than through the medium of courts of justice, whose duty it must be to declare all acts contrary to the manifest tenor of the Constitution void. Without this, all the reservations of particular rights or privileges would amount to nothing". 
Em primeiro lugar, não há nem uma sílaba no plano [de Constituição] sob análise que dê, direta ou indiretamente, às cortes nacionais, o poder de interpretar as leis de acordo com o espírito da Constituição, ou que lhes dê qualquer maior amplitude nesse aspecto que aquela reclamada pelas cortes de cada Estado. Eu admito, contudo, que a Constituição deva ser o parâmetro fundamental de interpretação das leis, e que, ainda que haja evidente oposição a isso, as leis devam ceder lugar à Constituição. Mas essa doutrina não é dedutível de nenhuma circunstância particular do plano da convenção, mas apenas da teoria geral de uma Constituição limitada; e, na medida em que isso é verdadeiro, é igualmente aplicável à maioria, senão a todos os governos dos Estados. Não pode haver objeção, portanto, nesse aspecto, à judicatura federal, que não acabe também ferindo as judicaturas locais em geral e que não sirva para condenar qualquer Constituição que tente estabelecer limites à discricionariedade legislativa."

Da leitura dos textos de Hamilton ficam bastante claras as enormes esperanças que o projeto constitucional americano deposita na figura dos juízes federais, sobretudo os da Suprema Corte, cujos atributos de retidão de caráter e conhecimento do direito os tornariam sujeitos acima da média das pessoas, capacitados, portanto, a distinguir as boas das más leis, e a proteger os verdadeiros interesses de Estado, em conseqüência, das maiorias passageiras e eventualmente tirânicas. Para Hamilton, "há muito menos razão para temer que o hálito pestilento das facções possa contaminar as fontes da justiça". ${ }^{45} \mathrm{De}$ outro lado, uma das razões a justificar a vitaliciedade dos juízes seria a necessidade de "longo e laborioso estudo para adquirir o competente conhecimento" das leis. ${ }^{46}$ Homens especiais precisariam por isso ser chamados à função e não haveria senão poucos deles com conhecimento suficiente das leis a qualificá-los para o cargo. ${ }^{47}$ " $\mathrm{E}$ fazendo as deduções necessárias em virtude da depravação ordinária da natureza humana, deve ser ainda menor o número daqueles que reúnem os requisitos de integridade com aqueles de conhecimento". 48

O que haveria a temer, então, desse ramo tão especial do governo? Para Hamilton, muito pouco, uma vez que o judiciário, sem poder fazer as leis que aplica, e sem ter força própria para executar suas decisões (neither force nor will), seria, entre os ramos do poder, o "menos perigoso" para os direitos políticos estabelecidos pela Constituição. ${ }^{49}$

45 O Federalista n. 81 .

46 O Federalista n. 78.

47 Idem, ibidem.

48 Idem, ibidem.

49 Idem, ibidem. A expressão the least dangerous branch tornou-se, a partir do texto de Hamilton, célebre, transformando-se depois no título de uma das mais importantes obras a enfrentar, no contexto da segunda metade do século passado, o papel crescente das cortes de justiça nos Estados Unidos: Alexander M Bickel, The Least Dangerous Branch.. 
É à luz do debate federalista que se deve entender, também, a decisão proferida pela Suprema Corte americana em Marbury v. Madison. ${ }^{50}$ Mas algumas notas adicionais a respeito do contexto específico em que o caso foi julgado fazem-se, igualmente, necessárias.

Nesse sentido, é preciso repisar, como já dito acima, que a Constituição americana de 1787 não outorgou explicitamente, à Suprema Corte dos EUA, o poder de invalidar leis que confrontassem os termos da própria Constituição Federal, ainda que inúmeros trechos do documento pudessem suportar essa conclusão, como o explicita o próprio texto de Hamilton $^{51}$. O tema, quando dos debates que geraram o texto constitucional, era particularmente controverso, e foi deixado sem solução explícita no texto posteriormente promulgado $^{52}$.

Com o silêncio do texto constitucional, abriu-se uma lacuna que viria a ser preenchida apenas uma década e meia depois. Em Marbury v. Madison, a Suprema Corte entendeu que o texto constitucional lhe dava, efetivamente, competência para a invalidação de leis federais contrárias à Constituição, o que serviu de mote para a declaração incidental de inconstitucionalidade da Sessão 13 do judiciary act de $1789^{53}$. Essa decisão tornou-se o marco fundador do constitucionalismo americano. ${ }^{54}$

O contexto em que se inserem os fatos referidos no caso é o da sucessão do presidente John Adams, que foi substituído na chefia de governo dos Estados Unidos por Thomas Jefferson, como resultado da eleição conduzida em $1800^{55}$. Esse foi um momento importante na história política dos Estados Unidos, pois a chefia de governo mudava de mãos, deixando os Federalistas de Adams, de viés político mais conservador e elitista, basicamente formado, como dito, por grandes comerciantes e latifundiários, e passando para os Republicanos de Thomas Jefferson, quase todos pequenos proprietários de terras, de viés político mais liberal, republicano e laico ${ }^{56}$. Naquele tempo, a Suprema Corte americana era, ela mesma, dominada por juízes ligados ao Partido Federalista de Adams,

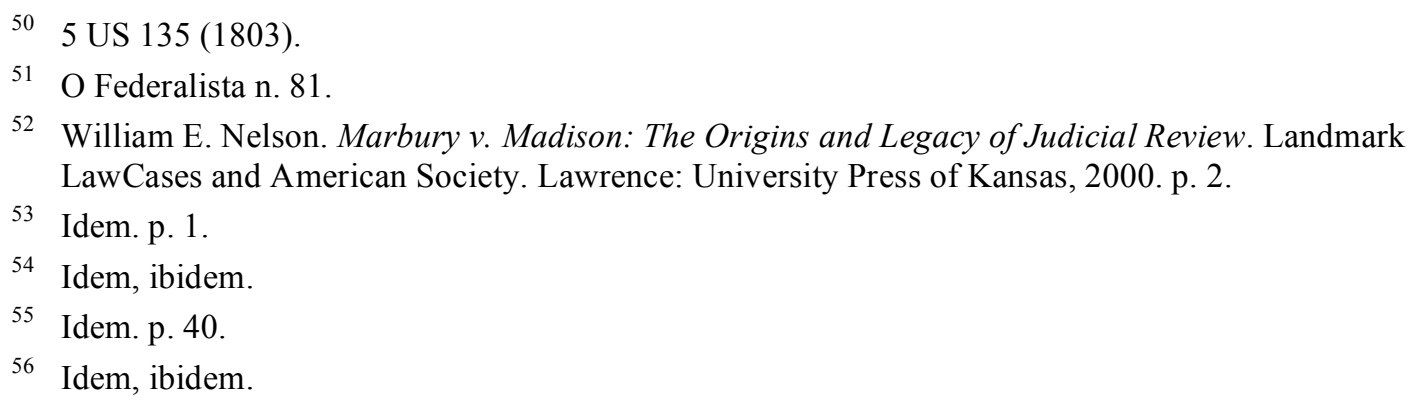


sendo que o próprio presidente do tribunal, John Marshall, fora conduzido ao cargo por indicação de Adams, logo no início de 1801 (Marshall havia sido, aliás, Secretário de Estado de Adams). ${ }^{57}$

A história dos EUA anota um papel particularmente importante para John Marshall durante a transição de governo entre Adams e Jefferson, inclusive como articulador político dessa transição. Marshall, apesar de Federalista, era um homem relativamente moderado e, aparentemente, tinha especial interesse em que aquele delicado processo de transição de governo se desse sem qualquer risco de ruptura institucional. ${ }^{58}$

John Adams, logo antes de terminar seu mandato, nomeou William Marbury como juiz de paz para o Distrito de Colúmbia, sendo que o efetivo empossamento de Marbury no cargo ficava dependente da expedição de um determinado documento oficial (a comission ou comissionamento). O mandato de John Adams acabou terminando antes que o documento fosse, de fato, expedido, e o novo presidente, ao tomar posse, acabou determinando ao Secretário de Estado, James Madison, que se abstivesse de entregar a Marbury o documento que lhe permitiria exercer as funções para as quais fora nomeado. ${ }^{59}$ Vale frisar que Marbury era um dos então chamados midnight judges, ou seja, um dos vários juízes apontados por Adams para novos cargos de judicatura às vésperas do final do seu mandato. ${ }^{60}$

Em um primeiro momento, Marbury e alguns outros midnight judges ingressaram, separadamente, com vários pedidos diante da Suprema Corte Americana, requerendo ao tribunal que obrigasse o Secretário de Estado a fornecer as razões pelas quais não havia, até então, expedido os documentos de nomeação. Posteriormente, e como nenhuma resposta havia sido apresentada por James Madison, o pedido acabou sendo convertido em um requerimento para que a corte determinasse diretamente, a Madison, que expedisse os ditos documentos. ${ }^{61}$

A base para a formulação desses pedidos diretamente à Suprema Corte americana consistia em uma lei federal que outorgava a esse tribunal competência originária para

\footnotetext{
57 Idem. p. 48.

58 Idem. p. 53.

59 Idem. p. 57.

60 Idem. p. 54.

61 Idem. p. 57.
} 
conhecer desse tipo de matéria (o judiciary act de 1789). Com fundamento nessa lei, o pedido de William Marbury foi formulado diretamente à Suprema Corte. Contudo, o voto condutor do julgamento, proferido pelo Presidente do Tribunal, Juiz John Marshall, acabou por simplesmente inadmitir o pedido de Marbury, ao argumento de que a Corte não seria competente para conhecer desse requerimento, eis que a Constituição Federal dos EUA não lhe atribuía tal competência e que, portanto, a lei federal em questão era, nesse particular, inválida. ${ }^{62}$

No julgamento em questão, ficou estabelecido pela primeira vez no direito americano que, sendo a Constituição a lei suprema dos EUA, ela deveria prevalecer sobre qualquer outra lei federal que conflitasse com seus dispositivos ${ }^{63}$. Sendo competência da Suprema Corte interpretar a lei e dizer o direito, seria perfeitamente possível a seus juízes, portanto, deixar de aplicar leis julgadas contrárias à Constituição, reconhecendo assim sua invalidade, independentemente até de maiores formalidades. ${ }^{64}$

Para decidir o caso que lhe era apresentado, o Juiz John Marshall escreveu um longo voto, abordando, especialmente, quatro distintas questões, a saber: (i) se Marbury teria direito ao cargo de juiz de paz para o distrito de Columbia, ao qual fora anteriormente nomeado por Adams, e, portanto, se teria direito à entrega do comissionamento necessário ao exercício das funções inerentes ao cargo, (ii) se, tendo tal direito, assistir-lhe-ia algum mecanismo ou ação judicial aptos a permitir sua salvaguarda e exercício, (iii) se, existindo tal mecanismo, seria ele equivalente ao writ of mandamus efetivamente impetrado e, finalmente (iv) se, havendo o direito e tendo sido bem escolhido o remédio, seria a Suprema Corte, de fato, o tribunal competente para resolver a questão.

Em resposta à primeira questão, Marshall chega à conclusão de que Marbury, de fato, teria direito ao cargo ${ }^{65}$. Marshall conclui, também, que esse direito, assim como qualquer outro direito regularmente estabelecido pelas leis americanas, seria passível de proteção judicial $^{66}$ e que, no caso concreto, o writ of mandamus seria a ação correta a ser

\footnotetext{
625 US 135 (1803).

63 É bem verdade que algumas outras decisões de Marshall, anteriores à decisão em questão, já haviam antecipado de alguma forma o argumento, referindo-se, contudo, a leis estaduais. V., especialmente, Ware v. Hylton, 3 U.S. (3 Dall.) 199 (1796).

645 US 135 (1803).

65 Idem.

66 Idem.
} 
utilizada para a proteção desse direito. Compreende a corte, em outras palavras, que haveria, na hipótese, amparo legal para determinar ao Secretário James Madison que entregasse o documento em questão a Marbury, caso a Suprema Corte fosse, de fato, competente para conhecer desse pedido. ${ }^{67}$ Todavia, Marshall conclui que a Suprema Corte não seria competente parar expedir a ordem, já que a lei federal que lhe outorgava competência originária para conhecer de casos semelhantes seria inconstitucional. ${ }^{68}$

Não é preciso tecer maiores explicações para demonstrar a importância que o julgamento teve para a história do constitucionalismo americano e mundial. O princípio de que "é enfaticamente o domínio e dever do órgão jurisdicional dizer o que o direito significa" representa, em última instância, o próprio instrumento que permitiu ao Poder Judiciário, com maior ou menor intensidade, imiscuir-se em questões de natureza política durante os já duzentos e poucos anos que se seguem à decisão. No entanto, para a verdadeira compreensão do papel político das cortes de justiça, torna-se especialmente relevante fazer alguma análise crítica do contexto em que a decisão se inseriu.

Em primeiro lugar, seria difícil tirar a razão daqueles que procurassem apontar os critérios que justificaram essa decisão como critérios de natureza eminentemente política, e não de estrita interpretação do direito, tal como Marshall faz parecer em sua justificação. Marshall era, ele mesmo, um federalista e, ao decidir como decidiu, acabou por avançar e garantir uma reserva para certos ideais federalistas no coração do governo republicano, reforçando o poder federal sobre o poder dos Estados, ao arrogar à corte federal o poder de invalidar leis estaduais e, especialmente, criando uma doutrina constitucional que poderia, subseqüentemente, fornecer os instrumentos necessários à proteção dos privilégios da classe dominante contra o avanço das idéias republicanas. E, de fato, em muitos momentos da história americana, o poder de judicial review foi usado exatamente para proteger os privilégios da classe dominante contra reformas de cunho liberal ou, mais amplamente, social. $^{69}$

Além disso, em certa medida, a Suprema Corte americana acabou "decidindo por não decidir" a controvérsia que estava em julgamento, usando de um subterfúgio jurídico-

67 Idem.

68 Idem.

69 Dois casos exemplares, discutidos adiante, consistem nos julgamentos de Dred Scott v. Sandford [60 U.S. (19 How.) 393, 493 (1857)] e Lochner v. People of State of New York [198 U.S. 45 (1905)]. 
processual (a negação da própria competência com base na inconstitucionalidade da lei atributiva correspondente) para omitir-se a uma decisão de mérito que poderia ter conseqüências mais severas no plano político (no contexto político então vigente, conceder ou negar, diretamente, o comissionamento a Marbury seriam decisões que gerariam, entre federalistas e republicanos, respectivamente, reações negativas potencialmente muito sérias). Considerado esse pano de fundo, não seria despropositado enxergar, na própria fundação do controle difuso de constitucionalidade, certa crítica que, hoje em dia, vem sendo lançada com grande intensidade ao próprio Supremo Tribunal Federal brasileiro: a omissão em decidir diretamente, pelo mérito, muitas das questões que the são apresentadas, omissão fundada, sobretudo, em razões de natureza política. Por outro lado, seria possível enxergar na decisão, também, uma racionalidade estratégica absolutamente relevante à atuação política num plano mais realista: às vezes, quando o exercício do poder é, ele mesmo, perigoso e não recomendado, a ameaça de seu exercício pode ser ação política suficiente e eficiente. $^{70}$

A decisão tomada pela Suprema Corte americana no caso em questão está, sem dúvida, fundada na ideologia de que as cortes não criam lei, mas apenas a interpretam, e tem o poder para tanto. Paradoxalmente, no entanto, a mesma doutrina afirma que as cortes não podem consistir em policy makers mas outorga a elas os instrumentos para agirem como tal; e é fundada por uma decisão que, em última palavra, deu ao conflito que lhe era proposto uma solução de acomodação, própria, evidentemente, aos arranjos políticos de interesse, mas não, classicamente, ao processo formal de adjudicação.

Esse paradigma de ação judiciária criado nos Estados Unidos no final do século XVIII tem seu contraponto direto no modelo francês de Constituição, instituído pelo movimento revolucionário no mesmo fechar do século XVIII. E a distinção estabelecida entre ambos sistemas lança suas origens, fundamentalmente, nas profundas diferenças que marcaram o ambiente político de cada uma das assembléias constituintes.

Aproximadamente um ano depois da ratificação da Constituição americana acontecia, na França, a tomada da Bastilha, metáfora e símbolo maior da queda do antigo

70 Em certo sentido, a Suprema Corte americana "avisou" publicamente o governo, por meio de sua decisão, que a ação cometida contra marbury fora claramente arbitrária, atingindo com esse "recado" dois objetivos distintos (i) satisfez em certo grau os republicanos e (ii) fez com que o próprio executivo modificasse seu padrão de conduta nos casos subseqüentes. 
regime. Imediatamente depois instaura-se a Assembléia Constituinte, que prepara e promulga, em 14 de setembro de 1791, a nova Constituição francesa.

A oposição histórica do modelo constitucional francês ao modelo americano, acima desenhado, pode ser notada pelo caráter peremptório da seguinte afirmação, feita por Lijphart: "a França foi por muito tempo considerada o melhor exemplo de país em que o princípio da soberania popular impedia qualquer aplicação da revisão judicial"71. Ainda que essa situação não perdure hoje com a mesma intensidade (Lijphart classifica a França, hoje, como um país em que vigora uma forma fraca de revisão judicial) ${ }^{72}$, sua formação histórica fornece um contraponto importante ao quadro institucional. Isso acontece, sobretudo, porque o esquema francês de divisão de poderes teve intensa influência no restante dos direitos de origem continental-européia, tendo, também, profunda influência sobre o direito administrativo brasileiro.

A primeira diferença marcante em relação ao modelo americano estava no modo de escolha dos juízes. Enquanto os juízes americanos eram excluídos do processo político eleitoral e tinham vitalicidade, como garantia de sua independência, a Constituição francesa de 1791 entregou a judicatura a juízes eleitos periodicamente pelo povo. Além disso, o texto constitucional cuidou do Poder Judiciário em seu capítulo V, estabelecendo (artigo $3^{\circ}$ ) que "os tribunais não podem nem imiscuir-se no exercício do poder legislativo, ou suspender a execução das leis, nem interferir com as funções administrativas, ou citar diante de si os administradores, em razão de suas funções". ${ }^{73}$ As duas principais características do modelo americano (controle judicial das leis e controle judicial da administração) estavam, portanto, proscritas do regime constitucional francês.

O artigo 203 da Constituição francesa de 1795 (a Constituição do Ano III) reproduz a restrição, estabelecendo que "os juízes não podem imiscuir-se no exercício do poder

\footnotetext{
71 Arend Lijphart, Modelos de Democracia: Desempenho e Padrões de Governo em 36 Países.

72 Idem, p. 257.

73 "Les tribunaux ne peuvent, ni s'immiscer dans l'exercice du Pouvoir législatif, ou suspendre l'exécution des lois, ni entreprendre sur les fonctions administratives, ou citer devant eux les administrateurs pour raison de leurs fonctions."
} 
legislativo, nem editar regulamentos; eles não podem impedir ou suspender a execução das leis, nem citar diante de si os administradores em razão de suas funções". ${ }^{74}$

O movimento revolucionário francês, ainda que guiado pela burguesia mercantil, foi um movimento de reação a privilégios minoritários. E a magistratura francesa era nitidamente associada à minoria privilegiada, consistindo o próprio título de magistrado em um privilégio hereditário, exercido com aberta venalidade. O paradigma francês forma-se, então, a partir da tentativa de constranger o mais intensamente possível seu papel. ${ }^{75}$

Em que pesem suas várias idas e vindas institucionais, a França apenas vai conhecer uma modalidade quase-judicial de controle de constitucionalidade das leis com a Constituição da Quinta República $(1958)^{76}$, que institui o Conseil Constitutionnel, composto de nove membros eleitos com mandato fixo e não renovável, proporcionalmente nomeados pelos Presidentes da República, da Assembléia Nacional e do Senado, mais um presidente, nomeado pelo Presidente da República, sendo todos completamente autônomos em relação ao Poder Judiciário. ${ }^{77}$ Todavia, mesmo a ação desse órgão constitucional é embutida no próprio processo legislativo, consistindo em uma espécie de controle ex ante. O juízo de inconstitucionalidade, concentrado e prévio à edição da lei, impede a sua

74 “Les juges ne peuvent s'immiscer dans l'exercice du Pouvoir législatif, ni faire aucun règlement. - Ils ne peuvent arrêter ou suspendre l'exécution d'aucune loi, ni citer devant eux les administrateurs pour raison de leurs fonctions".

75 "A França oferece um exemplo de como se estabelecera uma nobreza de toga... em torno da justiça e se autonomizaram os tribunais do rei. Desde 1467, sob Luís XI, aceitava-se que os juízes eram irremovíveis, mesmo os encarregados da acusação. Como visto, desde 1522 o próprio rei, por razões inclusive fiscais, aceitara a venalidade dos ofícios. Em 1604 a hereditariedade e a venalidade tornaram-se gerais. Os cargos eram comprados e sobreviveram registros da variação de seu preço... A venalidade do cargo foi abolida apenas em 1789, com a revolução. Em relação ao rei os magistrados adquiriram enorme independência. Como membros de um Parlamento... tinham o poder de rejeitar as leis... do rei, deixando de registrá-las conforme era exigido. Este papel 'legislativo' dos parlamentos (ou grandes tribunais) crescera à medida em que diminuíra a freqüência de convocação dos Estados Gerais. Os juízes devolviam a lei sem registro, indicando as razões num texto que se chamava remontrance. Picardi (...) mostra como progressivamente a prática torna-se um problema constitucional. O rei legislador do novo Estado moderno exigiria a submissão dos juízes à lei (expressão da voluntas principis) sem sucesso. Luís XIV editou uma ordennance civil em 1667 (...) cujos primeiros nove parágrafos regulavam a 'observância das leis'. O princípio novo cuja imposição se tentava era o da obediência do magistrado à lei. A doutrina tradicional, ao contrário, havia construído uma teoria de controle dos atos do rei pelos juízes (...). Esse confronto (rei $\mathrm{x}$ tribunais percorrerá todo o Antigo Regime e curiosamente encontra-se na origem da inexistência de controle judicial da constitucionalidade das leis na tradição francesa." (Cf. José Reinaldo Lima Lopes, $O$ direito na história).

76 Cf. Koopman, p. 70.

77 “Article 56 : Le Conseil Constitutionnel comprend neuf membres, dont le mandat dure neuf ans et n'est pas renouvelable. Le Conseil Constitutionnel se renouvelle par tiers tous les trois ans. Trois des membres sont nommés par le Président de la République, trois par le Président de l'Assemblée Nationale, trois par le Président du Sénat. En sus des neuf membres prévus ci-dessus, font de droit partie à vie du Conseil Constitutionnel les anciens Présidents de la Republique. Le Président est nommé par le Président de la République. Il a voix prépondérante en cas de partage." 
própria promulgação. Uma vez promulgada, com ou sem a manifestação prévia do Conseil Constitutionnel, uma dada lei não pode mais ser declarada inconstitucional por qualquer juízo ou tribunal. ${ }^{78}$

Afirmadamente, o modelo francês funda-se em um princípio de supremacia parlamentar irrestrita, e sua origem histórica associa-se à reação burguesa contra os privilégios aristocráticos do Antigo Regime. O medo dos juizes associado ao projeto revolucionário consiste, portanto, em um receio contra a "tirania das minorias". Já o modelo americano faz o inverso. Nasce, aparentemente, para consagrar certos privilégios das oligarquias do Sul e do Nordeste dos Estados Unidos. Confia em um corpo especializado de juízes a partir de um receio afirmado contra a "tirania das maiorias". No período que antecedeu a guerra civil americana, e novamente na década de 1930, esse sistema serviu, claramente, à defesa desses interesses oligárquicos e conservadores. Essa situação, contudo, muda radicalmente ao longo da década de 1950, fornecendo novamente, ao fim e ao cabo, exemplo e paradigma importantes para o processo subseqüente de judicialização e rearranjo institucional no Brasil.

\section{II}

\section{O PAPEL DA JUSTIÇA NA HISTÓRIA AMERICANA RECENTE}

$\mathrm{O}$ argumento em favor do poder entregue pelo constitucionalismo americano às cortes de justiça (proteção contra a "tirania das maiorias") conheceu seus dias de maior desprestígio aproximadamente 50 anos depois da decisão proferida no caso Marbury. A "mais repugnante e esconjurada das decisões da Suprema Corte", como a qualifica Berry

\footnotetext{
"Article 61 : Les lois organiques, avant leur promulgation, et les règlements des assemblées parlementaires, avant leur mise en application, doivent être soumis au Conseil Constitutionnel qui se prononce sur leur conformité à la Constitution. Aux mêmes fins, les lois peuvent être déférées au Conseil Constitutionnel, avant leur promulgation, par le Président de la République, le Premier Ministre, le Président de l'Assemblée Nationale, le Président du Sénat ou soixante députés ou soixante sénateurs. Dans les cas prévus aux deux alinéas précédents, le Conseil Constitutionnel doit statuer dans le délai d'un mois. Toutefois, à la demande du Gouvernement, s'il y a urgence, ce délai est ramené à huit jours. Dans ces mêmes cas, la saisine du Conseil Constitutionnel suspend le délai de promulgation.

Article 62 : Une disposition déclarée inconstitutionnelle ne peut être promulguée ni mise en application. Les décisions du Conseil Constitutionnel ne sont susceptibles d'aucun recours. Elles s'imposent aux pouvoirs publics et à toutes les autorités administratives et juridictionnelles."
} 
Friedman $^{79}$, consistiu naquela proferida no caso Dred Scott $v$. Sandford ${ }^{80}$, em que a Suprema Corte recusou-se a reconhecer a condição de cidadão do Missouri a um exescravo negro, decidindo que estes ex-escravos não poderiam ser considerados cidadãos, não podendo, por isso, invocar a jurisdição das cortes federais. Decidiu, ainda, que o Congresso não poderia proibir a escravidão, uma vez que o direito dos senhores sobre seus escravos estaria incluído no âmbito do direito de propriedade protegido pela Constituição americana. $^{81}$

Essa decisão inseriu-se no contexto de intensa agitação política que marcou aqueles anos imediatamente anteriores à guerra civil americana, colocando-se como uma tentativa de resolver judicialmente os conflitos que já se instauravam entre escravocratas e defensores da abolição do escravismo nos Estados Unidos. ${ }^{82}$ No entanto, "ainda que os historiadores possam debater acerca das causas exatas que envolveram a dissolução da União americana, Dred Scott certamente não resolveu a questão escravocrata, e os Estados Unidos acabaram lançados em uma sangrenta guerra civil., ${ }^{, 83}$

Robert Dahl chega inclusive a apontar a decisão como uma das causas que teriam levado à eclosão da guerra civil americana. ${ }^{84}$ Sobretudo, ela representou um marco para a perda de confiança dos cidadãos americanos em seu sistema de justiça. Na edição de 7 de março de 1857 do New York Evening Post, previa-se o "fim da Suprema Corte; pois um tribunal judicial que não está apoiado na confiança das pessoas logo será desconsiderado como poder do Estado, ou será dissolvido". No mesmo dia, lia-se no New York Daily Tribune: "Se epítetos e denúncias podem afundar um corpo judicial, a Suprema Corte dos Estados Unidos nunca mais será ouvida novamente". ${ }^{85}$ Não obstante isso, a maior parte das críticas parece ter-se dirigido à má escolha feita pela Corte em sua decisão, mas não ao caráter antidemocrático do controle judicial de constitucionalidade em si mesmo considerado (a dificuldade contra-majoritária). ${ }^{86}$

\footnotetext{
79 Barry Friedman, The history of the countermajorttarian difficulty, part one, cit., p. 415.

60 U.S. (19 How.) 393, 493 (1857).

81 V. Barry Friedman, ob. cit., idem.

82 V., tb., a respeito desse contexto histórico, Paul Finkelman, The Dred Scott Case, Slavery and the Politics of Law, 20 Hamline L. Rev. 1 (1996).

83 Barry Friedman, ob. cit., p. 417.

84 Robert A. Dahl, A preface to democratic theory, p. 83.

85 Barry Friedman, ob. cit., p. 417

86 Idem, 418 e ss.
} 
Outro mal momento da Suprema Corte surge em 1905, com a decisão do caso Lochner v. People of State of New York, ${ }^{87} \mathrm{em}$ que foram consideradas inconstitucionais as leis do Estado de Nova Iorque que estabeleciam condições mínimas de trabalho, adiantando o movimento que mais tarde dominaria o século XX, em direção aos direitos sociais e às liberdades de segunda geração. Em sua decisão, a Supre Corte estabeleceu que:

"O direito geral de estabelecer contratos no âmbito das relações comerciais é parte da liberdade protegida pela $14^{\mathrm{a}}$ Emenda e inclui o direito de comprar e vender trabalho, exceto quando controlado pelo Estado no exercício legítimo de seu poder de polícia.

A liberdade de contratar relacionada ao trabalho inclui ambas as partes envolvidas no contrato; uma delas é tão livre para comprar quanto a outra é para vender trabalho.

Não há base razoável para, com fundamento na proteção da saúde, interferir com a liberdade das pessoas ou com o direito de livre contratação, determinando as horas de trabalho, na profissão de padeiro. Nem pode uma lei que limite essas horas ser justificada como uma lei destinada a proteger a saúde pública ou a saúde dos indivíduos que exercem essa ocupação.

A Sessão 110 das leis trabalhistas do Estado de Nova Iorque, estabelecendo que nenhum empregado pode ser instado a permanecer trabalhando em padarias por mais que 60 horas em uma semana, ou 10 horas em um dia, não constitui exercício legítimo do poder de política do Estado, por consistir em uma interferência irrazoável, desnecessária e arbitrária no direito e liberdade dos indivíduos de contratar em relação ao trabalho e, por isso, está em conflito com a Constituição Federal, sendo nula de acordo com ela".

Lochner é, ainda hoje, um dos exemplos favoritos, utilizados a todo instante por aqueles que defendem o afastamento das cortes de justiça da vida política americana. Como anota Cass Sunstein, "o senso comum é no sentido de que Lochner foi uma decisão errada por envolver 'ativismo judicial': uma invasão ilegítima das cortes nos domínios reservados aos ramos políticos do governo." 88 Mas, além disso, mostrou novamente, como já ocorrera em Dred Scott, uma corte propensa a proteger os interesses de uma minoria conservadora, representativa dos estamentos dominantes da sociedade, contra avanços sociais conseguidos por meio do processo político representativo formal.

A tensão entre governo e corte potencializa-se no projeto de reformas sociais empreendido pelo presidente Roosevelt na década de 1930, marcado por forte intervencionismo na economia, o New Deal. Após um intenso choque de forças, no curso do qual Roosevelt ameaça inclusive modificar o desenho da corte, acrescendo novos

87198 U.S. 45 (1905).

88 V. Cass Sunstein, Lochner's Legacy, 87 Colum. L. Rev. 873 (1987), p. 874. 
membros para garantir-lhe a maioria necessária à aprovação da constitucionalidade de suas reformas, a corte entra em um período de relativo silêncio. ${ }^{89}$ Esse silêncio seria quebrado estrondosamente no inicio da década de 1950.

De fato, logo no início do pós-guerras surge a decisão que reabilitaria a reputação da Suprema Corte, tornando-se marco fundamental do processo de judicialização dos grandes temas políticos da vida americana tal como hoje concebido. Trata-se do caso Brown vs. Board of Education of Topeka, Kansas, decidido em $1954 .{ }^{90}$ A importância do caso é tamanha a ponto de existir, hoje, uma "Brown Foundation for Educational Equity, Excellence and Research", que inclui entre seus objetivos o de "informar o público sobre a paradigmática decisão" proferida neste caso. ${ }^{91}$

O caso Brown consistiu no julgamento conjunto de diversas ações coletivas de objeto semelhante, movidas contra os boards of education dos estados de Kansas, Carolina do Sul, Virginia, Washington DC e Dellaware. Uma delas, promovida pela National Association for the Advancement of Colored People (NAACP), deu nome ao caso. Entre os cerca de 200 autores representados pela NAACP estava Oliver Brown. Advogou no caso pela NAACP o já famoso jurista Thurgood Marshall, que depois viria a ser Ministro da Suprema Corte americana entre os anos de 1967-91.

Até aquele momento, no início da década de 1950, havia no direito americano um consenso importante quanto ao direito das pessoas à liberdade de associação, o que significaria que aos brancos não poderia ser imposto, contra a sua vontade, o convívio com negros, sob pena de violação dessa liberdade fundamental. A segregação de crianças a escolas diferentes com base em critérios raciais era aceita, portanto, como legalmente válida, desde que as condições materiais disponíveis nas escolas para brancos e negros fossem iguais. A doutrina legal vigente estabelecia um princípio de tolerância da segregação por cor, desde que as condições oferecidas a todos fossem consideradas semelhantes. Separate but equal, dizia o princípio.

89 V. Oscar Vilhena Vieira, Supremo Tribunal Federal: Jurisprudência Política. Editora Malheiros, 2002. p. 84.

90347 US 483 (1954).

91 "The Brown Foundation for Educational Equity, Excellence and Research was established in 1988 as a living tribute to the attorneys and plaintiffs in the landmark U.S. Supreme Court decision of 1954 Brown v. Board of Education. This decision signaled the end of legal segregation on the basis of race in this country. The Brown family and community leaders in Topeka, Kansas, established the Foundation to commemorate and document the activities and history makers involved in this historic court case." Cf. http://brownvboard.org/foundation/. 
Nos casos julgados pela Suprema Corte em 1954, com exceção apenas de um caso oriundo do Delaware, não foi possível encontrar diferenças substanciais entre os recursos disponíveis das escolas reservadas para a população branca e aqueles atinentes às escolas para negros. Não obstante, a Suprema Corte americana entendeu inconstitucional a segregação, formulando um princípio segundo o qual ela seria intrinsecamente prejudicial à população negra.

Para além da formulação desse princípio, a grande inovação de Brown, sob o ponto de vista da dinâmica do processo judicial, foi instituir um regime de reforma dos sistemas educacionais vigentes nos Estados afetados pela decisão, regime esse que foi controlado judicialmente, incluindo atividades que, sob quaisquer parâmetros tradicionais, seriam consideradas próprias às administrações estaduais, nunca a uma corte de justiça.

Do ponto de vista material, a decisão baseou o julgamento de inconstitucionalidade das normas que permitiam a segregação de estudantes com base em raça em três fundamentos principais, assim resumidos: (a) quando um Estado obriga-se a fornecer uma oportunidade para educação em suas escolas públicas, essa oportunidade é um direito que deve estar disponível a todos em termos iguais, (b) a segregação de crianças em escolas públicas apenas com base na raça retira das crianças pertencentes ao grupo minoritário oportunidades iguais de educação, ainda que as instalações físicas e outros fatores "tangíveis" sejam iguais, (c) a doutrina do "separate but equal," adotada em Plessy v. Ferguson, 163 US 537 (1896), não se aplica no campo da educação pública

Do ponto de vista processual, a decisão adotada foi a seguinte:

\footnotetext{
"Na medida em que estas são ações coletivas, e em virtude da ampla aplicabilidade desta decisão, e por conta da variedade de condicionantes locais, a formulação específica dos mecanismos de tutela judicial do direito protegido nestes casos apresenta problemas de considerável complexidade. Nos debates efetuados no caso, a consideração dos mecanismos de tutela apropriados esteve necessariamente subordinada à questão preliminar - a constitucionalidade da segregação em escolas públicas. Nós anunciamos agora que essa segregação consiste em negativa do direito de igualdade diante da lei. De modo a termos completo auxílio das partes na formulação dos mecanismos de tutela adequados, esses casos serão baixados à secretaria, e as partes serão intimadas a apresentar novos argumentos a respeito das questões n. 4 e 5 propostas pela Corte. O Procurador Geral da República é novamente convidado a participar dos debates. Os Procuradores Gerais dos Estados que exigem ou permitem a segregação de raça em escolas públicas também poderão comparecer como amici
} 
curiae mediante requerimento para tanto, a ser feito até 15 de setembro de 1954, com apresentação de memoriais em $1^{\circ}$ de Outubro de 1954".

A decisão relativa ao tipo de remédio processual pertinente à hipótese foi tomada após os inputs mencionados pela corte, e passou a ser conhecida como Brown II. Essa decisão consistiu em verdadeira revolução do paradigma processual liberal. Resumidamente, a decisão foi a seguinte:

“(a) as autoridades responsáveis pelos estabelecimentos de ensino são responsáveis em caráter primário por endereçar, resolver e elucidar os vários problemas locais que podem exigir solução com vistas à implementação dos princípios constitucionais aplicáveis,

(b) as cortes deverão avaliar se a ação dessas autoridades constitui uma forma de implementação real dos princípios constitucionais, eivada de boa-fé,

(c) em virtude de sua proximidade com as condições locais e por conta da possível necessidade de audiências subseqüentes, as cortes que originalmente julgaram estes casos podem desempenhar de forma mais eficiente essa função de avaliação,

(d) ao desenhar e efetivar mecanismos de tutela dos direitos aqui reconhecidos, as cortes serão guiadas por princípios de equidade - caracterizados pela flexibilidade na determinação das providências a serem cumpridas, e pela facilidade de ajustamento e reconciliação de necessidades públicas e privadas, (...)

(j) as cortes podem considerar problemas relacionados à administração das escolas, surgidos das condições físicas dos edifícios escolares, do sistema de transporte escolar, de questões ligadas ao corpo de funcionários, da revisão do desenho dos distritos escolares e das áreas levadas em conta para designar crianças a uma dada escola, de modo a alcançarem um sistema de admissão às escolas públicas baseado em critérios não raciais, podendo também rever leis e regulações locais na medida necessária à solução dos problemas supra mencionados, (...)

(1) durante o período de transição, as cortes permanecerão competentes para conhecer destes casos"

A decisão inaugura aquilo que passou a ser chamado nos Estados Unidos de institutional reform ou structural reform litigation..$^{92}$ Desta vez, a Suprema Corte mostra-se

92 "As a genre of constitutional litigation, structural reform has its roots in the Warren Court era and the extraordinary effort to translate the rule of Brown v. Board of Education into practice. This effort required the courts to radically transform the status quo, in effect to reconstruct social reality. The courts had to overcome the most intense resistance, and, even more problematically, they had to penetrate and restructure large-scale organizations, public school systems. The imagery was rural and individualistic the black child walking into an all-white school - but the reality, especially by the mid 6o's, as the focus shifted to the urban centers and the nation at large, was decidedly bureaucratic.

Brown was said to require nothing less than the transformation of "dual school systems" into "unitary, nonracial school systems," and that entailed thoroughgoing organizational reform. It required new procedures for the assignment of students, new criteria for the construction of schools; reassignment of 
aparentemente sensível (responsiva ${ }^{93}$ ) aos interesses de minorias efetivamente oprimidas. A chamada Warren Court, ou seja, a corte presidida por Earl Warren, é marcada por um novo ativismo, de caráter francamente liberal. ${ }^{94}$

Para além de seu ativismo, a Warren Court assume claramente como papel próprio às cortes de justiça o de transformar as instituições. Ela é a representação e encarnação do “juiz herói” ou do "juiz Hércules"que acaba por povoar o imaginário jurídico no período do Estado Social ${ }^{95}$. A partir do caso Brown, os Estados Unidos conhecem um intenso processo de intervenção das cortes de justiça em presídios, hospitais e instalações públicas congêneres. Um intenso período, em suma, de declarada intromissão das cortes de justiça no campo das políticas públicas.

A reação conservadora ao ativismo da corte que julgou o caso Brown vem na eleição de 1968. Como o presidente Lyndon Johnson decide não concorrer à reeleição, em virtude do forte movimento pacifista e das críticas crescentes à participação americana na Guerra do Vietnã, Richard Nixon é lançado candidato pelo Partido Republicano e vence as eleições também com base em uma plataforma de franca contestação à Warren Court, não apenas por suas decisões ligadas à proteção dos "direitos dos criminosos” (Miranda v.

faculty; revision of the transportation systems to accommodate new routes and new distances; reallocation of resources among schools and among new activities; curriculum modification; increased appropriations; revision of interscholastic sports schedules; new information systems for monitoring the performance of the organization; and more. ${ }^{*}$ In time it was understood that desegregation was a total transformational process in which the judge undertook the reconstruction of an ongoing social institution. Desegregation required a revision of familiar conceptions about party structure, new norms governing judicial behavior, and new ways of looking at the relationship between rights and remedies.

No one had a road map at the outset. No one had a clear vision of all that would be involved in trying to eradicate the caste system embedded in a state bureaucracy, or how the attempt would transform the mode of adjudication. The second Brown decision was far from such a vision: it was but a recognition of the magnitude of the task and an attempt to buy time. It delegated the reconstructive task to the lower federal judges. They, in turn, discovered what the task required and adjusted traditional procedural forms to meet the felt necessities. Legitimacy was equated with need, and, in that sense, procedure became dependent upon substance. It was the overriding commitment to racial equality that motivated the procedural innovation and that was seen as the justification for the departures from tradition." Owen M. Fiss, The Forms of Justice, p. 2-3.

93 Philippe Nonet e Philip Selznik: Law and Society in transition: toward responsive law, New York: Harper and Row, 1978.

94 Earl Warren foi Presidente da Suprema Corte Americana entre os anos de 1953 e 1969. Warren Burger sucedeu-o no cargo, em que permaneceu até 1986. Em 1986, a presidência foi assumida por William Rehnquist, que a exercu até 2005. O atual presidente é John G. Roberts, Jr. O período em que Warren esteve na presidência é considerado como um período de especial ativismo da corte, especialmente no que se refere ao uso do poder de judicial review para efetivação de direitos humanos e sociais.

95 O conteito do juiz Hércules é de Ronald Dworkin: Law's Empire. V., ainda, François Ost, Júpiter, Hércules, Hermes: tres modelos de juez. 
Arizona, ${ }^{96}$ por exemplo), mas também pela própria decisão proferida no caso Brown. Depois da renúncia de Nixon, Ford (outro republicano) o substitui em 1974. As indicações feitas por Nixon e Ford à Suprema Corte mudam profundamente seu perfil liberal, iniciando um período de contenção bem maior no caráter ativista da corte. ${ }^{97}$

Brown muda para sempre o paradigma referente às funções próprias a uma corte de justiça na experiência americana. Como veremos adiante, muda, também, o paradigma próprio ao instrumental disponível a esses órgãos para o exercício de suas atividades. Não obstante, a decisão continuou gerando na literatura americana preocupações tão intensas quanto sempre em relação ao caráter contra-majoritário dessa ação política.

Robert Dahl, por exemplo, permanecia, à época em que o caso Brown foi decidido, como um crítico feroz do modelo de democracia americano, baseado em um aparato constitucional que daria supostamente as bases fundadoras do convívio democrático, restando garantido por uma corte de justiça forte, ativa e com capacidade de sobrepor suas decisões às preferências legislativas.

Para Dahl, o foco de uma teoria democrática deveria estar não em seus prérequisitos constitucionais, mas sim em seus pré-requisitos sociais, no acordo moral e político fundamental, sem o qual nenhum convívio democrático é possível. Para Dahl, a atuação das cortes de justiça nos Estados Unidos apenas fez, historicamente, por mascarar os dilemas morais e políticos que dividiam a nação, agudecendo-os. Por isso sua teoria das "poliarquias" quer focar-se, sobretudo, nestes últimos, e não no aparato legal que permitira a existência do convívio democrático:

“A inclinação [à democracia] atribuída ao pensamento americano pela Convenção Constitucional e a subseqüente apoteose de seu produto obscureceram, creio eu, um pensamento realista e preciso sobre os requisitos da democracia. É significante que, até a queda de Fort Sumter, a disputa entre Norte e Sul tenha sido, com apenas algumas importantes exceções, formulada quase inteiramente na linguagem do direito constitucional. A tragédia representada pela decisão do caso Dred Scott não foi tanto o resultado, mas sobretudo uma demonstração do tipo de pensamento vigente à época.

96 V. 384 U.S. 436 (1966).

97 A indicação de Burger para a presidência da corte, por Nixon, dá-se, em parte, para tentar reverter o intenso ativismo da corte anterior. Algumas decisões importantes relativas à afirmação de direitos sociais ocorrem nessa época, mas, de forma geral, a presidência de Burger marca um período mais conservador na Suprema Corte. Uma referência geral sobre a história desse tribunal pode ser obtida em Rehnquist, The Supreme Court. Especificamente sobre o período de Warren, v. a coletânea organizada por Mark Tushnet, The Warren Court in historical and political perspective. 
Porque fomos ensinados a acreditar na necessidade de freios e contrapesos constitucionais, nós damos pouco crédito aos freios e contrapesos sociais. Nós admiramos a eficácia da separação de poderes em constranger maiorias e minorias, mas nós frequentemente ignoramos a importância de certas restrições impostas pela separação social de poderes. (...) [N]a ausência de certos prérequisitos sociais, nenhum arranjo constitucional pode produzir uma república que não seja tirana. A história de inúmeros Estados Latino-Americanos é, penso, prova suficiente disso. Reversamente, um acréscimo na presença desses pré-requisitos sociais pode ser bem mais importante para o fortalecimento da democracia que qualquer desenho constitucional particular. Se nós estivermos de fato preocupados com as tiranias de maioria e minoria, a teoria das poliarquias sugere que as primeiras e cruciais variávels às quais os cientistas políticos devem dirigir sua atenção são sociais, não constitucionais." ${ }^{98}$

Para além dessa crítica de legitimidade, não foram poucas as vozes que tentaram apontar, empiricamente, o insucesso do programa de reformas sociais judicialmente empreendidas pela Warren Court. $^{99}$

Fato é, todavia, que o paradigma fornecido por Brown mantém-se central nas discussões atinentes ao processo de judicialização da vida política até hoje. O arsenal de novos instrumentos fornecido pela decisão às cortes de justiça está, como dito, na base da crítica instrumental da qual pretendo tratar, com mais vagar, adiante.

\section{III}

\section{A JUSTIÇA NA EUROPA DO SÉCULO XX}

Paralelamente aos desenvolvimentos havidos nos Estados Unidos na década de 1950, acima resumidos, que ocorria na Europa? Basicamente o mesmo movimento de expansão crescente do papel reservado às cortes de justiça. Nas palavras de John Ferejohn, “desde a Segunda Guerra Mundial, tem havido uma profunda transferência de poder dos órgãos legislativos em direção às cortes de justiça e outras instituições legais por todo o mundo. Essa transferência, que tem sido chamada 'judicialização', tornou-se mais ou

98 Robert A. Dahl, A preface to democratic theory, p. 83.

99 V. Gerald N. Rosemberg, The Hollow Hope: Can the courts bring about social change? 
menos global em seu alcance, o que se nota pelo fato de ser tão marcada na Europa, e especialmente em tempos recentes na Europa do Leste, quanto é nos Estados Unidos". 100

Em primeiro lugar, é preciso notar que, ao longo do século XX, também a Europa desenvolveu uma tradição específica de controle de constitucionalidade. "Ela não é, e não poderia ser, totalmente independente da tradição americana. É, no entanto, uma tradição com um caminho próprio", ${ }^{101}$ fundada sobretudo no controle concentrado realizado por meio de cortes constitucionais.

Essa tradição começa com Kelsen, a quem é dado redigir, depois da Primeira Guerra Mundial, a Constituição da nova república austríaca. ${ }^{102}$ A Constituição austríaca de 1920 consagra, então, o modelo de controle concentrado de constitucionalidade que, após a segunda guerra mundial, passa a ser exportado para inúmeros outros países europeus.

Além desta, outras condicionantes, como se verá abaixo, também atuaram no processo de judicialização das relações políticas na Europa. Não obstante isso, neste primeiro momento, quero retornar ao paradigma francês, antes referido, para analisar sua evolução no pós-guerras, demonstrando assim o movimento de convergência para a judicialização que parece espalhar-se globalmente nesse período.

Uma das melhores análises comparativas do processo de judicialização da vida política na França da Quinta República é a de Alec Stone Sweet. ${ }^{103}$ Stone Sweet retoma essa análise em um artigo publicado em 1999, em que procura demonstrar que, sob certas condições, tríades, estruturas sociais fundamentais constituídas por duas partes litigantes e uma esfera autônoma de solução de conflitos, formam um mecanismo essencial de mudança e adaptação política, um "microcosmos de governança"104. Nesse seu artigo, os exemplos de sua teoria consistem nos processos de judicialização das relações de poder no

100 John Ferejohn, Judicializing Politics, Politicizing Law, p. 41. Prossegue o autor: "The spectacles of Italian judges undermining Italy's postwar system of musical cabinets, or of newly energized French judges hounding prime ministers and presidents, are only the most visible aspects of these developments. One could also point to the role, and recent success, of judges in seeking to arrest and prosecute dictators and military leaders. Additionally, our own United States Supreme Court's intervention into electoral politics in Bush v. Gore was yet another manifestation of this trend".

${ }^{101}$ V., a respeito, Torbjörn Vallinder, When the Courts Go Marching In, p. 23.

${ }^{102}$ Idem, ibidem.

${ }^{103}$ Alec Stone, The birth of judicial politics in France: The Constitutional Council in comparative perspective.

${ }^{104}$ Sobre a idéia de tríade, v. tb. Martin Shapiro, "Courts", in Fred Greenstein and Nelson Polsby (ed.), Handbook of Political Science, vol. 5, Massachusetts: Addison-Wesley Pub Co., 1975, pp. 321-365. 
âmbito do GATT (com a formação de um verdadeiro contencioso de feitio judicial no âmbito da OMC, hoje claramente observável) e na França do pós-guerras. Sigo, aqui, fiel à descrição das transformações ocorridas no contexto francês tal como referida neste artigo por Stone Sweet. ${ }^{105}$

Referi no item I desta parte que, em 1958, a França passa a conhecer, pela primeira vez em sua história, uma forma quase-judicial de controle de constitucionalidade, quando da instituição do Conseil Constitutionnel. A chave para a compreensão do processo de judicialização na experiência constitucional francesa recente está justamente na criação desse órgão.

Tem razão Stone Sweet ao dizer que, como estruturas normativas, as Constituições francesas marcaram-se, genericamente, por serem ao mesmo tempo duras e frágeis. ${ }^{106}$ "Elas legitimavam a autoridade daqueles que estavam (temporariamente) no controle do Estado, mas eram incapazes de organizar relações duradouras com aqueles que competiam por esse controle". ${ }^{107}$ Conforme desenvolve Stone Sweet, a institucionalização desse tipo de relacionamento entre governo e oposição vem a ocorrer, justamente, através do processo de mediação de tipo judicial desenvolvido pelo Conselho Constitucional a partir de sua criação e, sobretudo, a partir de sua reforma em 1974.

A Constituição francesa inovou a tradição constitucional vigente em dois aspectos principais. Primeiro, outorgou capacidade normativa ao Poder Executivo, ainda que dependente de ratificação pelo legislativo. Depois, estabeleceu, como já dito, uma forma de controle de constitucionalidade ex ante, destinada, sobretudo, a verificar se a lei em questão havia sido produzida em conformidade com o processo legislativo respectivo. Até por isso - e nesse ponto mantendo-se fiel à tradição francessa avessa à intervenção judiciária ou mesmo legal nas questões representativas - a Constituição de 1958 não exigiu qualquer formação jurídica para os membros do Conselho Constitucional, que nasce, pois, sobretudo como um órgão de controle político. Completando o caráter restritivo desse mecanismo de controle prévio de constitucionalidade, apenas poderiam reclamar ao

\footnotetext{
105 Alec Stone Sweet, Judicialization and the construction of governance.

106 "brittle", na expressão original.

107 Idem, p. 172.
} 
conselho o Presidente da República, o Presidente da Assembléia Nacional, o Presidente do Senado e o Primeiro Ministro. ${ }^{108}$

Essa ação restrita conhece substancial alargamento em 1974, quando, por meio de reforma constitucional, passa a ser aberta a via da reclamação ao Conselho a quaisquer 60 parlamentares. Paralelamente a essa reforma, o Conselho Constitucional age, pela primeira vez, sob requerimento do Presidente do Senado e com apoio da doutrina e da mídia, no sentido de invalidar uma lei desejada pelo governo, fazendo-o com base em questões substanciais e não de processo legislativo, ligadas aos postulados de uma "parcialmente não escrita e mal definida" carta de direitos. ${ }^{109}$ A partir de então, a solicitação e as respostas do Conselho Constitucional tornam-se mais e mais freqüentes, como demonstra a tabela 01, abaixo. Sobretudo, releva notar que tais solicitações vieram principalmente de conjuntos de ao menos 60 congressistas, o que parece significar, em outras palavras, que o recurso ao Conselho consistiu, basicamente, em um instrumento político utilizado pelas oposições. $^{110}$

\section{(Tabela 01) \\ ATUAÇÃO DO CONSELHO CONSTITUCIONAL FRANCÊS \\ (Anos de 1958-1993)}

\begin{tabular}{lcccc}
\hline & 1959-1973 & $1974-1980$ & $1981-1987$ & $1988-1993$ \\
Solicitações de manifestação (total) & 9 & 66 & 136 & 98 \\
De iniciativa do Presidente & 0 & 0 & 0 & 0 \\
De iniciativa do Primeiro Ministro & 6 & 2 & 0 & 4 \\
De iniciativa do Presidente da Assembléia & 0 & 2 & 0 & 1 \\
De iniciativa do Presidente do Senado & 3 & 0 & 2 & 3 \\
De iniciativa de 60 parlamentares & ---- & 62 & 134 & 90 \\
Decisões & 9 & 46 & 92 & 70 \\
Decisões contrárias ao texto legal & 7 & 14 & 49 & 38 \\
Decisões favoráveis ao texto legal & 2 & 32 & 43 & 32 \\
\hline
\end{tabular}

(Fonte: Alec Stone Sweet, Judicialization and the construction of governance, in Comparative Political Studies, vol..32, n. 2, p. 147-184 (1999).)

A confirmação dessa hipótese é dada por Stone Sweet, nos seguintes termos:

"Desde 1974, os casos decididos pelo Conselho têm consistido, quase que exclusivamente, em solicitações de revisão formuladas pela oposição, alegando a inconstitucionalidade de leis propostas pelo governo e pela maioria parlamentar. Quando no poder, os partidos de esquerda e

${ }^{108}$ Idem, p. 173.

109 Idem, ibidem.

${ }^{110}$ Os dados referentes ao controle de constitucionalidade no Brasil pós-1988 revelam exatamente o mesmo fenômeno. Cf., a propósito, a tabela 02, adiante. 
direita tem acusado a crescente intervenção do Conselho sobre o processo legislativo, e ambos ameaçaram abolir o órgão de modo a restaurar a "soberania da vontade geral". Na oposição, tanto a esquerda quando a direita têm explorado, sem qualquer vergonha, a capacidade desses mecanismos trídicos de solução de disputas (TDR) de obstruir a regra da maioria.

As oposições são atraídas pelas TDRs por uma razão simples: o Conselho é a única instituição capaz de alterar resultados legislativos que não é controlada pelo governo nem pela maioria parlamentar. As solicitações de ação do Conselho estendem o processo legislativo de sorte a fazê-lo incluir um outro estágio: a produção trídica de normas jurídicas. O movimento em direção à TDR modifica o contexto estratégico da política francesa, redistribuindo iniciativa política em favor da oposição e reduzindo a influência do governo e da maioria sobre os resultados legislativos. Quando a oposição lança mão desses mecanismos, o governo e a maioria são colocados na defensiva, forçados a participar de um processo que eles não podem controlar". ${ }^{111}$

A ação expandida do Conselho Constitucional produz, então, "um processo autosustentável de judicialização", que inclui uma espécie de "chantagem constitucional", na qual a oposição aprendeu que poderia melhorar sua influência no processo legislativo ameaçando questionar a constitucionalidade de regras que lhe fossem indesejadas. Em geral, essa ameaça passou a fornecer as bases para um arranjo parlamentar mais amplo, no qual a maioria deixa de simplesmente impor sua vontade para negociar atenuações, modificações, acomodações dos interesses oposicionistas. ${ }^{112}$

O processo também fez com que as questões de constitucionalidade fossem incorporadas ao próprio processo legislativo. O legislador, a partir da ação do Conselho, passou a aprender como produzir as normas que desejava sem criar espaços nos quais a ação do órgão pudesse localizar inconstitucionalidades. Finalmente, na linha identificada por Vallinder, a ação do Conselho passou mais e mais a tomar feição judicial, envolvendo discussão sobre princípios jurídicos, atuação de profissionais especializados em direito, discussões doutrinárias e, finalmente, uma preocupação mais detida com a fundamentação das decisões, dando conta de todos os argumentos levantados por cada parte em favor ou contra a constitucionalidade de uma dada lei.

A ação do Conselho de Constitucionalidade altera, portanto, substancialmente o paradigma francês, introduzindo na política nacional (i) elementos fortemente contramajoritários e (ii) judicialização.

\footnotetext{
111 Alec Stone Sweet, ob. cit., p.174.

112 Idem, p. 175.
} 
Ampliando um pouco o horizonte de análise, é de se destacar, ainda, o papel das convenções internacionais de proteção dos direitos humanos no processo de judicialização da política européia. Esse processo começa pela Carta das Nações Unidas de 1945 e segue pela Declaração Universal dos Direitos do Homem de 1948, encontrando seu ponto culminante na Convenção Européia para a Proteção dos Direitos Humanos.

Em muitos lugares esse sistema internacional de proteção dos direitos humanos forneceu o material de que necessitavam os juízes (quaisquer juízes, como no caso americano) para engajarem-se ativamente nos processos políticos locais respectivos. Novamente, apenas para ficar com o paradigma já construído, lanço mão do caso francês.

Em 1975, a Cour de Cassassion francesa, órgão máximo do judiciário nacional (mas sem competências de controle de constitucionalidade - domínio exclusivo do Conseil Constitutionnel - nem de controle de atos da administração pública - campo de ação privativa do Conseil D'Était), resolve, pela primeira vez, invalidar uma lei nacional ao argumento de estar em confronto com o direito comunitário europeu. O caso, Administration des Douanes v. Société Cafès Jacques Vabre, recebeu a atenção de Mauro Cappelletti, em seu famoso ensaio The 'mighty problem' of judicial review and the contribution of comparative analysis. ${ }^{113}$

Como explica Cappelletti, o artigo 55 da Constituição francesa outorgou aos tratados e acordos internacionais ratificados autoridade superior àquela das próprias leis francesas. A partir de então, a Corte de Cassação pode construir uma doutrina segundo a qual qualquer juiz francês seria competente para deixar de aplicar a legislação francesa quando entendesse estar em confronto com o direito comunitário. A Corte de Cassação foi bastante clara em declarar que não se tratava de uma forma de controle de constitucionalidade, mas de mera hipótese de interpretação e aplicação do princípio da derrogação da lei inferior pela lei de hierarquia superior. A legislação comunitária, integrada ao direito nacional, não teria status constitucional, não se enquadrando sua interpretação, por isso, nas hipóteses (restritíssimas) de controle de constitucionalidade.

113 Mauro Cappelletti, The 'mighty problem' of judicial review and the contribution of comparative analysis. Cappelletti ainda cuida do papel exercido pelo Conselho de Estado francês no processo de judicialização das relações políticas nesse país, "verdadeira Corte Constitucional”. V., a respeito, ob.cit., p. 414-15. V., ainda, Mauro Cappelletti, O Controle judicial de constitucionalidade das leis no direito comparado. 
Decidir pela não aplicação das leis locais em favor do direito comunitário seria, portanto, nesse contexto, mera atividade de resolução de antinomias. ${ }^{114}$

“O controle judicial da ação parlamentar, banido pela porta principal pela Constituição nacional, acabou entrando pela janela larga representada por uma carta de direitos transnacional. Ao invés de ter sido banido, o controle judicial foi, nesse sentido, ampliado, porque passa a significar controle judicial de caráter transnacional."115

Cappelletti também demonstra como a existência do hoje denominado Tribunal de Justiça das Comunidades Européias, com poderes de judicial review e capacidade para decidir questões a requerimento dos tribunais nacionais, no que concerne à interpretação do direito comunitário, contribuiu para o próprio processo de formação e consolidação da Europa cominitária. ${ }^{116}$ A existência do tribunal garantiu a consolidação de um direito supranacional que forjou unidade política, em um processo semelhante ao da própria união das ex-colônias norte-americanas. ${ }^{117}$

Segundo anota a literatura especializada, observam-se processos mais ou menos intensos de judicialização da vida política em quase todos os países da Europa atual, inclusive nos países do Leste Europeu, que, como a Hungria, têm inserido cartas de direitos e cortes constitucionais em suas novas constituições. ${ }^{118}$ Mesmo em países em que essa tradição nunca esteve presente, como é o caso da Inglaterra ${ }^{119}$, o movimento pode já

\footnotetext{
114 "[T] $[$ he Cour de Cassation does not hesitate to interpret dispositions in international treaties as long as they concern private interest.” Jacqueline Lucienne Lafon, France, p. 297.

115 Mauro Cappelletti, The 'mighty problem'..., p. 421.

116 Ob. cit., p. 425 e ss.

117 V. tb. Tim Koopmans, Courts and Political Institutions: A Comparative View.

118 Cf. Torbjörn Vallinder, When the Courts Go Marching In, p. 24.

119 V. Herbert M. Kritzer, Courts, Justice, and Politics in England, p. 81. V. tb. Jerold L. Waltman, Judicial Activism in England, p. 33.
} 
ser intensamente sentido. $\mathrm{O}$ mesmo se poderia falar em relação à Italia ${ }^{120}$, Alemanha ${ }^{121}$, Holanda $^{122}$, Suécia $^{123}$, e tantos outros países.

\section{JUSTIÇA, AUTORITARISMO E TRANSIÇÃO DEMOCRÁTICA: O PAPEL DO JUDICIÁRIO NA}

\section{AMÉrica Latina}

Este pequeno apanhado do processo de judicialização da vida política na segunda metade do século passado não poderia estar completo sem algumas poucas palavras sobre sua evolução peculiar na América Latina. Essa é, sem dúvida, uma história que ainda está por ser contada, e a bibliografia existente a respeito é inacreditavelmente mais escassa se comparada àquela relativa à expansão das cortes de justiça nos países centrais. Mas três importantes peculiaridades podem ser ao menos indicadas.

Em primeiro lugar, o contexto político da região no pós-guerras. Em contraste com o processo de democratização e crescente institucionalização que marcou esse período na Europa, a América Latina viu surgirem, nesse mesmo instante histórico, duros regimes autoritários. Evidentemente, torna-se difícil falar na expansão do poder judiciário em um contexto de autoritarismo. Como anota C. Neal Tate, a primeira das condições necessárias ao processo de expansão do papel das cortes de justiça é a existência de regimes democráticos, a existência de Estado de Direito, de rule of law. ${ }^{124}$ Em um contexto de exceção, reduz-se profundamente o papel dos tribunais judiciários na vida política de uma nação. Todavia, o grau de "independência" e "resistência" ao regime de exceção por parte das cortes de justiça variou bastante, como demonstram, v.g., as experiências brasileira e

${ }^{120}$ V. Mary L. Voncansek, Constitutional Politics in Italy. V. tb. Giuseppe Di Federico, Italy: A Peculiar Case, p. 233, Carlo Guarnieri, Judicial Independence and Policy-Making in Italy, p. 243, Michael Mandel, Legal Politics Italian Style, p. 261; Mary Volcansek, Judicial Activism in Italy,p. 117.

${ }^{121}$ V. Erhard Blankenburg, Changes in Political Regimes and Continuity of the Rule of Law in Germany, p. 249; Tim Koopmans, Courts and Political Institutions: A Comparative View, p. 63; Alec Stone, Compex Coordinate Construction in France and Germany, p. 205, Christine Landfried, Germany, idem, p. 307 , H. G. Peter Wallach, Reunification and Prospects for Judicialization in Germany, idem, p. 325; H. G. Peter Wallach, Judicial Activism in Germany, p. 154.

${ }^{122}$ V. Tim Koopmans, Courts and Political Institutions: A Comparative View, p. 76; Jan ten Kate and Peter J. Van Koppen, The Netherlands: Toward a Form of Judicial Review, p. 369.

${ }^{123}$ V. Barry Holmström, Sweden, p. 345; Joseph B. Board, Judicial Activism in Sweden, p. 174

124 C. Neal Tate, Why the expansion of judicial power?, p. 28. 
argentina. Além disso, o contexto de exceção, a vida sob o modelo de "direito repressivo" ${ }^{\text {125 }}$, fez nascerem aqui e a ali importantes mecanismos de proteção do indivíduo contra abusos de poder estatal, do que as doutrinas do amparo, do habeas corpus e do mandado de segurança são exemplos importantes. ${ }^{126}$

Uma vez superados os regimes de exceção na América Latina, houve um movimento mais ou menos homogêneo ligado à constitucionalização de direitos sociais. Esse movimento, em um contexto de democracias emergentes, com profundas desigualdades e débitos sociais, assume também peculiaridades próprias, marcadas, sobretudo, pela tentativa de implementação desses novos direitos, em um contexto de profunda escassez de recursos públicos utilizáveis. Essa parece ser a segunda peculiaridade importante a ser anotada.

Uma terceira condicionante consiste na influência dos organismos internacionais de apoio ao desenvolvimento no sentido de construir uma noção bastante específica de rule of law na região. Essa influência é notada na ação de órgãos como o Banco Mundial, ou de programas como o USAid. Ela trabalha com uma noção institucionalista relativa à importância das cortes de justiça para o desenvolvimento econômico das economias dependentes. Por força dela, a noção de eficiência tem sido introduzida intensamente no discurso latino-americano atinente ao papel do judiciário na abertura democrática. As propostas recentes de reforma do aparato judicial no Brasil marcaram-se, não por acaso, por essa intensa influência.

Para não perder o foco da discussão que tento empreender nesta parte do texto, deixarei de examinar a primeira das condicionantes referidas acima, atinente ao papel de maior ou menor resistência desempenhado pelos órgãos judiciários durante os regimes de

${ }^{125}$ O conceito é de Philippe Nonet e Philip Selznik (Law and Society in transition: toward responsive law). "Governing power is repressive when it gives short shrift to the interests of the governed, that is, when it is disposed to disregard those interests or deny their legitimacy. As a result the position of the subject is precarious and vulnerable" (p. 29). "In its most distinct and systematic form repressive law displays the following characteristics : 1. Legal institutions are directly accessible to political power; law is identified with the state and subordinated to raison d'etat; 2 . The conservation of authority is an overriding preoccupation of legal officialdom. In the "official perspective" that ensues, the benefit of the doubt goes to the system, and administrative convenience weighs heavily; 3 . Specialized agencies of control, such as the police, become independent centers of power; they are isolated from moderating social contexts and capable of resisting political authority; 4. A regime of "dual law" institutionalizes class justice by consolidating and legitimating patterns of social subordination; 5 . The criminal code mirrors the dominant mores; legal moralism prevails" (p. 33). V. tb. Celso Fernandes Campilongo, Direito e Democracia.

${ }^{126}$ V. Cândido Rangel Dinamarco, A função das Cortes Supremas na América Latina e Mauro Cappelletti. $O$ Controle judicial de constitucionalidade das leis no direito comparado, p. 4. 
exceção latino-americanos. Se tanto, contento-me em registrar, para esse propósito, que a história recente da região parece colocar o órgão judiciário brasileiro em uma posição de independência e resistência algo mais intensa que aquela verificada em vários dos outros regimes de exceção que dominaram a América Latina, o que talvez tenha se tornado, ainda hoje, uma condicionante adicional do processo de judicialização em nosso país. ${ }^{127} \mathrm{O}$ confronto com a experiência argentina, como referi acima, pode dar conta do que quero dizer: já no contexto da democratização, o Presidente Carlos Menem não teve pudores de, sentindo necessidade de aprovar suas reformas, aumentar, em 1990, o número de Ministros na Suprema Corte de cinco para nove, preenchendo os cargos recém-criados com nomes de sua estrita confiança. ${ }^{128}$

O primeiro ponto a tratar fica sendo, portanto, aquele ligado à constitucionalização de direitos sociais.

$\mathrm{Na}$ Argentina, esse movimento tem sido seguido de uma aparente tendência dos tribunais a reconhecer a exigibilidade imediata desses direitos, sobretudo no campo do direito à saúde. Para além disso, tem-se verificado, aqui e ali, modalidades de litígio de direito público semelhantes àquelas próprias à structural reform litigation americana.

${ }^{127}$ V., sobre esse tema, os vários ensaios reunidos em Siri Gloppen, Roberto Gargarella e Elin Skaar (ed.), Democratization and the Judiciarye Irwin P. Stotzky, Transition to Democracy in Latin America: The Role of the Judiciary. V. tb. Mark J. Osiel, Dialogue with Dictators: Judicial Resistance in Argentina and Brazil.

${ }^{128}$ V. Owen M. Fiss, The Right Degree of Independence. Roosevelt havia ameaçado fazer algo semelhante nos Estados Unidos da década de 1930, de sorte a tentar conter o intenso ativismo da Suprema Corte Americana, traduzido em verdadeiro esquema de bloqueio das reformas do New Deal. Algo semelhante foi também empreendido pelo regime militar brasileiro no final de 1965, quando o número de integrantes do Supremo Tribunal Federal foi aumentado de 11 para 16, oportunidade em que o General Castelo Branco pode indicar, às vagas criadas, os Ministros Adalício Coelho Nogueira, José Eduardo do Prado Kelly, Oswaldo Trigueiro de Albuquerque Mello, Aliomar de Andrade Baleeiro e Carlos Medeiros Silva. Aliás, nova investida do regime militar contra o tribunal aconteceria em janeiro de 1969, quando, por Ato Institucional, seriam aposentados os Ministros Nunes Leal, Hermes de Lima e Evandro Lins e Silva. Ao todo, o regime militar brasileiro foi capaz de indicar ao STF 32 ministros. Humberto de Alencar Castelo Branco indicou Adalício Coelho Nogueira, José Eduardo do Prado Kelly, Oswaldo Trigueiro de Albuquerque Mello, Aliomar de Andrade Baleeiro, Carlos Medeiros Silva, Eloy José da Rocha, Djaci Alves Falcão e Adaucto Lucio Cardoso. Artur da Costa e Silva indicou Raphael de Barros Monteiro, Themistocles Brandão Cavalcanti, Moacyr Amaral Santos e Carlos Thompson Flores. Emílio Garrastazu Médici indicou Olavo Bilac Pinto, Antonio Neder, Francisco Manoel Xavier de Albuquerque e José Geraldo Rodrigues de Alckmin. Ernesto Geisel indicou João Leitão de Abreu, João Baptista Cordeiro Guerra, José Carlos Moreira Alves, Carlos Fulgêncio da Cunha Peixoto, Pedro Soares Muñoz, Decio Meirelles de Miranda e Luiz Rafael Mayer. Finalmente, João Baptista de Oliveira Figueiredo indicou Clovis Ramalhete Maia, Firmino Ferreira Paz, José Néri da Silveira, Alfredo Buzaid, Oscar Dias Corrêa, Aldir Guimarães Passarinho, José Francisco Rezek, Sydney Sanches e Luiz Octavio Pires e Albuquerque Gallotti. O último dos Ministros indicados pelo regime militar brasileiro a afastar-se do tribunal foi Sydney Sanches, que aposentou-se em abril de 2003. 
Essas investidas incluiriam condenações do Estado a prestar serviços de creche a policiais mulheres, ordens judiciais ligadas à reforma de presídios e outras semelhantes. ${ }^{129}$

“Como é sabido, os sistemas de saúde pública nacional e local têm sofrido deterioração progressiva nas últimas décadas. Essa deterioração se tornou mais aguda nos anos noventa e alcançou seu ponto culminante durante os meses que se seguiram à crise desatada em dezembro de 2001. A situação dos hospitais públicos e o fornecimento de tratamentos e medicamentos aos setores mais pobres e marginalizados da população evidenciam há anos os duros efeitos do retrocesso do Estado no cumprimento de sua função como garante do direito constitucional à saúde. No contexto desse processo, diversos atores têm recorrido aos tribunais federais e locais exigindo medidas judiciais contra as omissões ou ações excludentes das burocracias a cargo das dependências estatais e hospitais públicos. As decisões judiciais geradas dão conta do fenômeno incremental de organização da sociedade civil em torno do problema sanitário e da incorporação da estratégia de reclamação judicial ao conjunto de ferramentas de motivação. De outra parte, do ponto de vista da tutela judicial, as sentenças difundidas em publicações jurídicas mostram uma variedade de ordens de ação e omissão com distintos graus de interferência judicial na gestão da administração pública". ${ }^{130}$

De forma muito semelhante ao que tem ocorrido no Brasil, o fornecimento de antiretrovirais para o tratamento da AIDS também tem motivado um importante contencioso de implementação de direitos sociais na Argentina. Decisão paradigmática nesse sentido foi aquela proferida no caso Asociación Benghalensis y otros v. Estado Nacional, julgado em 2000. Outras moléstias têm ensejado decisões semelhantes, como, por exemplo, a doença de Kostman (caso Campodónico de Beviacqua, Ana v. Estado Nacional, julgado em 2000) e a esclerose múltipla (caso Asociación de Esclerosis Múltiple v. MSASN, julgado em 2003). ${ }^{131}$

Além disso, sobretudo a partir da reforma constitucional de 1994, que introduziu o amparo colectivo, tem crescido o uso de class actions na experiência argentina, o que

\footnotetext{
${ }^{129}$ Paola Bergallo, Justicia y experimentalismo: la función remedial del poder judicial en el litigio de derecho público en Argentina.

130 Idem, p. 12.

131 Idem, ibidem.
} 
contribui, igualmente, para o desenvolvimento de um processo de judicialização bem parecido com o brasileiro. ${ }^{132}$

Também na Colômbia a idéia de outorgar justiciability aos direitos sociais ganhou corpo a partir de decisões da Corte Constitucional, que construiu a noção do mínimo vital. ${ }^{133}$ Fora do campo dos direitos sociais e já dentro da esfera relativa à ação judiciária sobre o cenário político, o exemplo da Costa Rica talvez seja um dos mais eloqüentes, pois foi por meio de decisão judicial da Suprema Corte que o presidente Oscar Arias "adquiriu" o direito de concorrer à reeleição. ${ }^{134} 135$

Já o judiciário chileno tem se mostrado bem menos propenso a esse tipo de incursão ativista, não obstante, como anota Javier Couso, tenha o Chile alcançado um dos mais sólidos regimes legais da região latino-americana, com níveis de corrupção comparáveis aos dos países membros da OCDE e um grau de respeito pelos postulados do Estado de Direito "lendário entre os países latino-americanos", o que, em tese, deveria conduzir a um grau mais intenso de exercício do controle judicial da ação parlamentar e executiva. $^{136}$

Isso talvez se explique pela presença de políticas públicas efetivas. Como anota Pablo Ruiz-Tagle, "[o] retorno à democracia no Chile e as reformas sociais da década de 1990, da perspectiva da equidade e inclusão social, tiveram um forte impacto e permitiram ao Chile reduzir seus níveis de pobreza de 38.6\%, em 1990, para 20.6\%, em 2000. Os avanços feitos na redução da indigência durante essa década foram também significativos, reduzindo-a de $12.9 \%$ para 5.7\%. No entanto, desde 1996 os níveis de indigência mantiveram-se estáveis em 5.7\%, o que motivou a reorientação das estratégias de combate à pobreza. Hoje, de acordo com as informações fornecidas pela pesquisa chamada Casen 2003, a redução da pobreza e da indigência tem continuado e, agora, $18.8 \%$ da população vivem abaixo da linha da pobreza, ao passo em que $4.7 \%$ vivem abaixo da linha da

\footnotetext{
${ }^{132}$ V. Gustavo Maurino, Ezequiel Nino \& Martín Sigal, Acciones Colectivas: Análisis Conceptual, Constitucional, Jurisprudencial, Procesal y Comparado.

${ }^{133}$ V. Julieta Lemaitre Ripoll, El Coronel sí tiene quien le escriba: la tutela por mínimo vital en Colombia.

${ }^{134}$ V. a respeito Rogelio Pérez-Perdomo, Rule of Law and Lawyers in Latin America.

${ }^{135}$ Exposições mais detalhadas sobre o processo de judicialização da política nestes e em outros países latinoamericanos (Mexico, Colômbia, Peru, Chile, Argentina, Venezuela, Costa Rica e Brasil) podem ser encontradas em Alan Angell, Rachel Sieder e Line Schjolden (ed.), Judicialization of Politics in Latin America.

${ }^{136}$ V. Javier A. Couso, The Politics of Judicial Review in Chile in the Era of Democratic Transition.
} 
indigência." ${ }^{137}$ Para que se tenha uma idéia do que isso significa, os números respectivos são, no Brasil, de $25.1 \%$ e $16.0 \%{ }^{138}$

Para além dessa possível explicação, contudo, a menção ao caso chileno dá um mote adequado para que se passe à condicionante seguinte, ligada à exportação do rule of law para a América Latina. ${ }^{139}$

Essa idéia trabalha claramente sobre a formulação institucionalista, segundo a qual a qualidade das "instituições" representaria determinante crucial para o desenvolvimento econômico das nações. Essas “instituições” consistiriam, em poucas palavras, no conjunto de normas de comportamento, códigos de conduta, leis, convenções, práticas vigentes em uma determinada sociedade, condicionadas por sua vez pela qualidade dos órgãos estatais e estruturas sociais que as aplicam. Em suma, são "as regras do jogo", como aponta o mais famoso dos institucionalistas, Douglas North. ${ }^{140}$

A literatura institucionalista ressalta a importância de um regime bem estruturado de proteção jurídica da propriedade, pois, sem esse regime, desmotivam-se os investimentos e agregam-se custos importantes à captação de recursos. Parte desse regime inclui a existência de órgãos que garantam o cumprimento dos contratos e a execução das obrigações. O papel do judiciário estaria, então, em desempenhar essa função, pautando sua ação, ademais, pelos princípios da segurança, previsibilidade, não intervenção no domínio da vontade de contratar, agilidade na solução de conflitos e cobrança de dívidas.

Gloppen, Gargarella e Skaar resumem a linha fundamental do argumento: "as cortes de justiça são importantes para o funcionamento e consolidação de regimes democráticos", entre outras coisas, porque elas "facilitam o governo, contribuindo para a

\footnotetext{
137 Pablo Ruiz-Tagle, Poverty and the Creation of Fundamental Rights.

${ }^{138}$ Fonte: CETS - Centro de Estudos do Terceiro Setor (EAESP/FGV) - dados disponíveis em http://integracao.fgvsp.br/13/noticias.htm\#Injustiça e Centro de Políticas Sociais (IBRE/FGV) - dados disponíveis em http://www3.fgv.br/ibrecps/queda_da_miseria/inicio_q.htm.

139 Digo isso porque o exemplo chileno é normalmente apontado como um dos mais fiéis no sentido de observância desses princípios de boa gestão pública defendidos pelo Banco Mundial. Além disso, apesar de "deparar-se com um dos mais desafiadores níveis de congestionamento judicial na America Latina”, o judiciário chileno "desfruta de maior confiança pública que a maior parte dos sistemas legais" na mesma região, segundo o Banco Mundial. V. Maria Dakolias, Court Performance around the World, p. 27. Outro elogio à contenção do judiciário chileno, acompanhado de uma análise das justiças latinoamericanas formatada nos moldes da crítica institucional que passo a descrever, pode ser encontrado em William C. Prillaman, The judiciary and democratic decay in Latin America: declining confidence in the rule of law.

${ }^{140}$ Cf. Douglas C. North: Institutions, Institutional Change, and Economic Performance, p. 3.
} 
construção do rule of law e criando um ambiente propício ao desenvolvimento econômico". ${ }^{141}$

$\mathrm{Na}$ visão institucionalista, a noção de rule of law, de legalidade ou Estado de Direito, transporta-se de seu significado ligado à proteção da dignidade humana para referir, exatamente, o conjunto de "regras claras do jogo", que permite o desenvolvimento econômico. Esse princípio do rule of law precisaria ser exportado para os países latinoamericanos, portanto, "não apenas para proteger direitos humanos, mas também para ajudar a garantir um nível satisfatório de desenvolvimento econômico, político e social". ${ }^{142}$ Essa é, recentemente, a bandeira do movimento americano de law and development, de sorte que a construção de "judiciários fortes e independentes" passou a ocupar "o lugar mais importante nas agendas de órgãos de desenvolvimento nos Estados Unidos e Europa, do Banco Mundial, do Fundo Monetário Internacional, da Ordem dos Advogados americana e até da Suprema Corte dos Estados Unidos". ${ }^{143}$

Briant Garth dá conta de como o movimento de law and development coordena sua ação na América Latina em dois momentos diferentes: primeiro, na década de 1970 e, depois, na época atual. ${ }^{144}$ A mudança nas estratégias de ação é, claramente, reflexo da incorporação desses guidelines institucionalistas, reforçando, em tempos recentes, a atenção sobre os órgãos judiciários. ${ }^{145}$

Na década de 1970, a ideologia dominante envolvia diminuição do papel do Estado e atenção no mercado. Nesse contexto, a liderança dos movimentos desenvolvimentistas na América Latina coube a economistas, não a juristas. No campo do direito, o movimento de law and development concentrou esforços no treinamento de uma nova geração de juristas na América Latina, "reorientada" em direção “às aproximações instrumentalmente pragmáticas dos advogados corporativos americanos". ${ }^{146}$ Hoje, a nota de atuação é dada pelo consenso relativo ao papel importante desempenhado pelas instituições na construção

\footnotetext{
${ }^{141}$ Siri Gloppen, Roberto Gargarella e Elin Skaar, Introduction: The Accoutability Function of the Courts in New Democracies.

${ }^{142}$ Cf. Irwin P. Stotzky e Carlos S. Nino, The Dificulties of the Transition Process, p. 3.

${ }^{143}$ Cf. Bryant G. Garth, Building Strong and Independent Judiciaries Through the New Law and Development: Behind the Paradox of Consensus Programs and Perpetually Disappointing Results.

144 Idem, p. 384 e ss.

145 Idem, ibidem.

146 Idem, 385.
} 
dos mercados. O direito, por isso, assume posição central, e a atenção é focada na reforma dos órgãos judiciários latino-americanos.

É claro que existem dois pólos opostos a orientar a ação desenvolvimentista, cada qual correspondendo a um aspecto distinto da noção de rule of law. Um é ligado à proteção de direitos humanos, o outro à criação das condições institucionais necessárias ao desenvolvimento. Talvez o primeiro pudesse implicar ativismo judiciário mas o segundo, no entanto, certamente remete a um judiciário mais contido, concentrado em suas funções de adjudicação de conflitos e efetivação dos contratos. Um Judiciário, sobretudo, eficiente. $^{147}$

$\mathrm{Na}$ ação do Banco Mundial sobre as instituições latino-americanas, o tema da reforma dos órgãos judiciários é, por isso, central, e remete ao incremento na eficiência desses órgãos. Estudos motivados por essa visão já apontaram, por exemplo, os efeitos perniciosos da ineficiência e da falta de previsibilidade da justiça brasileira sobre o crescimento econômico. ${ }^{148}$ Em decorrência dessas idéias, parece que, no contexto das reformas latino-americanas (a brasileira é exemplo claro disso), o tema da eficiência tem consistido na condicionante principal. ${ }^{149}$

Esse foco na eficiência marca, claramente, as discussões relativas à ação das cortes de justiça na América Latina. Em tese, nos países em desenvolvimento se poderia acrescentar, diria o argumento, uma razão a mais para a crítica da judicialização: ela

147 "An effective judiciary is predictable, resolves cases in a reasonable time frame, and is accessible to the public.” Cf. Maria Dakolias, Court Performance around the World, p. 1

148 Cf. Armando Castelar Pinheiro: Judiciário e Economia no Brasil.

149 "Efficiency was chosen as the starting point for three reasons. First, because most of its assessment indicators can be quantitatively measured using objective data, efficiency provides a sound basis for comparison.' While public perception is essential to judicial reform efforts (as part of a "multi-method approach" to assessing efficiency), it may be more difficult to compare on an international basis given that there are cultural and institutional differences. A second reason to focus on efficiency is that congestion, cost, and delay are the problems most often complained about by the public in most countries, 20 and thus often perceived as the most pressing. In recent years, moreover, market-oriented economic reforms and political democratization-most acutely in developing countries-have triggered demand for conflict resolution. Courts are not all equipped to deal with the surge in demand caused by privatization, greater foreign investment, and other economic and political changes. Finally, efficiency is a promising starting point for the study and design of judicial reform because of its relatively apolitical nature. The Colombian judiciary, for example, has many deeply rooted problems of judicial independence and corruption-as well as court congestion-but has chosen to begin with efficiency. The former two issues are so political in nature that the judiciary alone cannot begin to tackle them without the concurrent undertaking of major political steps. Efficiency is a more neutral area in which changes can begin without major changes in the structure of government and, in Colombia, without directly challenging the drug trade". Maria Dakolias, Court Performance around the World, p. 5-6. 
contribui para um grau maior de imprevisibilidade institucional, agrega custos ao processo econômico e dificulta o desenvolvimento. Nesse sentido, e ainda na linha do argumento, a judicialização da vida política seria, talvez, um luxo ao qual os países pobres não se devessem da.

Como tento mostrar abaixo, essa "lição" dos institucionalistas parece não ter sido seguida pelos órgãos judiciários nacionais.

\section{V}

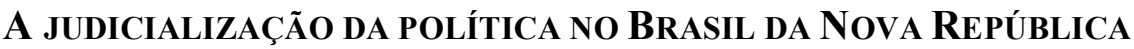

Em sua já referida introdução a The Global Expansion of Judicial Power ${ }^{150}$, C. Neal Tate procura fornecer um inventário das condições que, reunidas, tornariam possível, em um dado ambiente favorável, a eclosão do fenômeno de judicialização da política.

São elas (i) a existência de um regime de governo democrático ${ }^{151}$, (ii) a existência de uma "política de direitos", traduzida ou não em uma carta de direitos ou em uma declaração constitucional de direitos fundamentais ${ }^{152}$, (iii) a existência de grupos de pressão que tenham identificado os tribunais judiciais como possíveis arenas para a veiculação de seus interesses ${ }^{153}$, (iv) o uso eventual das cortes como instrumento político manejado pela oposição para impedir a edição de leis que ela, pelos canais representativos tradicionais, não conseguiria impedir ${ }^{154}$, (v) a existência de "instituições majoritárias inefetivas", isto é, incapazes de reunir em torno de si apoio público suficiente para defender suas políticas diante de possíveis ataques originados no Poder Judiciário ${ }^{155}$, (vi) uma percepção geral negativa quanto às instituições originalmente responsáveis pela formulação de políticas públicas, vindo esse sentimento negativo de receios públicos

\footnotetext{
${ }^{150}$ C. Neal Tate, Why the expansion of judicial power?, p. 27.

${ }^{151}$ Idem, p. 28.

152 Idem, 29.

${ }^{153}$ Idem, 30.

${ }^{154}$ Idem, ibidem.

${ }^{155}$ Idem, 31.
} 
quanto a clientelismo, personalismo, corrupção ${ }^{156}$, etc. (vii) inércia proposital quanto ao trato de certas questões particularmente delicadas (aborto, por exemplo) por parte das instituições majoritárias, que deixam deliberadamente, com isso, que tais questões sejam tratadas por via judicial ${ }^{157}$.

A reunião de várias dessas características cria ambiente favorável para o fenômeno de judicialização da política, mas não implica, necessariamente, esse resultado. Para que ele seja alcançado, seria preciso, ainda, que estivesse disseminado na sociedade (ou ao menos entre os juízes) o entendimento de que, dadas certas circunstâncias, seria próprio ao Poder Judiciário participar na formulação de políticas que em outras circunstâncias poderiam ser tidas como esfera de atuação discricionária de outros órgãos, com o poder de, ocasionalmente, substituir ao menos em parte as políticas formuladas por esses outros órgãos por suas próprias políticas. ${ }^{158}$

Além disso, sob um ponto de vista prático, ainda segundo Tate, é muito mais provável que o fenômeno ocorra diante da existência de uma oposição mais ou menos clara entre a orientação política dominante nas instituições majoritárias e aquela dominante nas instituições judiciárias, quer sejam essas posições respectivamente de direita e esquerda, quer sejam de esquerda e direita. ${ }^{159}$

Tendo em mente essas condicionantes, a análise do caso brasileiro à luz dos achados de Tate parece dar conta, eloqüentemente, de explicar o intenso movimento de judicialização da vida política nacional.

Não por acaso, o processo de judicialização no Brasil ocorre, substancialmente, após 1988, ou seja, no contexto da consolidação do regime democrático. Sem esse regime seria, efetivamente, impensável a idéia de judicialização da política. Sem um judiciário livre, e sem instituições livres que possam interagir com ele, toda a formulação de políticas

156 Idem, ibidem.

157 Idem, 32.

158 Idem, p. 33.

${ }^{159}$ V., a respeito, o quadro fornecido por C. Neal Tate na p. 35 do mesmo trabalho já citado. Quanto a esse último ponto, os exemplos históricos são fartos e significativos. Como já visto, Marbury v. Madison foi o resultado de um embate político entre um Judiciário de viés conservador, legatário de um governo conservador derrotado, e um Poder Executivo de viés liberal. A onda de extremo ativismo que atingiu a Suprema Corte norte-americana na década de 30 foi o resultado de pressões conservadoras na própria corte para barrar as reformas do New Deal. E, de certo modo, o mesmo poderia ser dito quanto às primeiras decisões pró-direitos humanos da Warren Court, na década de 50. 
públicas passa a originar-se nos centros autoritários de poder, e isso esgota boa parte da complexidade que pode haver nos processos de formulação dessas políticas.

O outro elemento importante acrescentado à vida institucional brasileira em 1988 foi uma intensa "política de direitos", traduzida por toda a declaração de direitos civis, políticos, econômicos e sociais constantes da Constituição Federal de 1988. Novamente, não parece ser por acaso que boa parte dos litígios em que se traduz nosso processo de judicialização da política consiste em litígios nos quais se busca efetivar o conteúdo genérico dos direitos constantes da Constituição, inclusive (talvez especialmente) no que se refere aos direitos chamados positivos, isto é, de cunho econômico e social, que apresentam, por certas características que lhes são peculiares, mais intensos problemas quando de sua implementação por via judicial ${ }^{160}$.

A existência de grupos de interesse dispostos a utilizar os tribunais judiciais como canais para a veiculação de suas respectivas agendas é percebida igualmente no Brasil, tendo sido, aliás, institucionalizados os canais de que eles podem utilizar-se para veicular judicialmente suas agendas. Essa é a leitura possível de textos como a Lei da Ação Civil Pública (Lei n. 7.347/85), a partir de 1990 conjugada ao Código de Defesa do Consumidor (Lei n. 8.078/90), diplomas que institucionalizaram a veiculação de interesses da sociedade civil organizada por meio do processo judicial. Ao lado dessa ação institucionalizada de associações de interesse e classe, há, no Brasil, um Ministério Público ativo e independente, dotado de uma agenda própria de defesa de certos interesses e políticas públicas (notadamente ligadas às áreas do welfarismo - saúde, educação, etc. - e a interesses de cunho difuso ligados à regulação no Estado Social, particularmente nos campos da prestação de serviços públicos, da proteção ao meio ambiente e da defesa do consumidor).

Ator por excelência das ações civis públicas, independente e dotado de garantias próprias à magistratura, destinadas a assegurar sua autonomia (vitaliciedade, por exemplo), o Ministério Público brasileiro, verdadeira singularidade de nosso arranjo institucional, é

\footnotetext{
${ }^{160}$ V., sobre a noção de direitos de cunho positivo, Charles Fried, Right and Wrong, p. 110. V ainda Mark Tushnet, Alternative Forms of Judicial Review; Civil Rights and Social Rights: The Future of the Reconstruction Amendments; New Forms of Judicial Review and the Persistence of Rights - and Democracy - Based Worries; Social Welfare Rights and the Forms of Judicial Review; State Action, Social Welfare Rights, and the Judicial Role: Some Comparative Observations e Non-Judicial Review. V. tb. Carol Harlow, Public Law and Popular Justice.
} 
como que um grupo de pressão oficial, financiado e suportado pelo Estado mas independente dele, cujo objetivo é endereçar demandas da sociedade civil não organizada, ou que tem dificuldades para se organizar. E ele não se faz de rogado em assumir essa função tutelar da sociedade.

Os membros do Ministério Público brasileiro são indivíduos que se auto-localizam no espectro político dentro das categorias da "esquerda" ou "centro-esquerda", que reconhecem as respectivas instituições como canais próprios à veiculação de demandas sociais e à a promoção do bem estar geral da população e que identificam na sociedade brasileira um alto grau incapacidade para a defesa autônoma de seus próprios interesses ${ }^{161}$, justificando, a partir daí, sua ação em defesa desses mesmos grupos, freqüentemente por meio da propositura de ações judiciais.

O uso das cortes como instrumento político manejado pela oposição para impedir a ação de leis que ela, pelos canais representativos tradicionais, não conseguiria impedir, é fenômeno também documentado no Brasil. Foi objeto de extensa pesquisa empreendida por uma equipe de pesquisadores encabeçada por Luiz Werneck Vianna ${ }^{162}$.

Até o fechamento da pesquisa organizada por Vianna, os partidos de esquerda haviam sido responsáveis por $40,4 \%$ de todas as ações diretas de inconstitucionalidade

161 Entre os integrantes do Ministério Público Federal, 87,5\% concordaram totalmente ou em termos com a afirmação de que a sociedade brasileira seria hipossuficiente, julgando, por isso, que "as instituições da Justiça devem atuar afirmativamente para protegê-la" (Ela Wiecko V de Castilho e Maria Tereza Sadek, O Ministério Público Federal e a administração da justiça no Brasil, São Paulo: Sumaré, 1998). Segundo resultados da mesma pesquisa, $88,5 \%$ dos promotores entrevistados concordaram total ou parcialmente com a idéia de que o Ministério Púbico deve ser canal de demandas sociais com vistas ao alargamento do acesso à justiça, transformando o Judiciário em um lugar privilegiado para a solução de conflitos coletivos (Ob. cit., idem). Outros 80,5\% anuíram total ou parcialmente com a idéia de que caberia ao Ministério Público exigir da Administração Pública a asseguração dos direitos previstos na Constituição Federal, nas leis e nas promessas de campanha, acrescentando que onde há lei garantindo direitos, não pode haver discricionariedade administrativa. Coerentemente, apenas $37 \%$ dos membros da instituição concordaram total ou parcialmente que a atuação do órgão deveria ser baseada em um saber neutro e despolitizado (Ob. cit., idem). Além disso, é interessante notar que os membros do Ministério Público Federal mostraram um alto grau de indulgência para com as instituições judiciárias, comparativamente à sua análise das instituições políticas. Sua avaliação sobre o desempenho do Ministério Público Federal e Estadual, do Supremo Tribunal Federal, do Superior Tribunal de Justiça, e das Justiças Estadual e Federal em ambos os graus de jurisdição foi substancialmente superior à avaliação que fizeram sobre o desempenho do Governo Federal e do Congresso Nacional. V., a respeito, Castilho e Sadek, ob. cit. Em uma escala de 1 a 5, a avaliação geral das instituições judiciárias teria coincidido com uma nota 3,19, e a das instituições políticas com uma nota 1,94. Esses resultados foram deduzidos atribuindo valores de 1 a 5 para cada uma das categorias apresentadas na pesquisa (ótimo, bom, regular, ruim e péssimo) e, subseqüentemente, ponderando-se essas notas pelos respectivos percentuais, excluídas as respostas sem opinião, para efeito de comparação global.

${ }^{162}$ V. Luiz Werneck Vianna et al., A judicialização da politica e das relações sociais no Brasil. 
ajuizadas contra atos normativos originados do Poder Executivo federal e por 18,5\% de todas aquelas ajuizadas contra atos originados do Poder Legislativo federal (vale notar que outros $21,3 \%$ das ações movidas contra o Legislativo federal foram iniciadas por associações de trabalhadores, que são, normalmente, ligadas de uma forma ou de outra a esses partidos de esquerda).

$\mathrm{Na}$ esfera estadual, 44,3\% das ações diretas de insconstitucionalidade promovidas contra leis estaduais foram ajuizadas pelos governadores dos Estados respectivos ${ }^{163}$. Em números absolutos, as ações diretas de inconstitucionalidade ajuizadas por partidos de esquerda contra atos do Executivo federal foram 132, as ajuizadas pelos mesmos partidos contra leis federais foram 66 e as ajuizadas por governadores contra suas respectivas casas legislativas foram em número de $450^{164}$.

Conforme dados disponibilizados pelo Supremo Tribunal Federal em seu sítio, o número total de ações de inconstitucionalidade ajuizadas por governadores e partidos políticos era, em março de 2005 , respectivamente de 859 e 663 , o que equivalia a $25,73 \%$ e $25,70 \%$ de todas as ações de inconstitucionalidade até então ajuizadas. Não por acaso, governadores e partidos políticos consistiam, naquele momento, nos dois principais promotores de ações direitas de inconstitucionalidade, seguidos depois pela Procuradoria Geral da República.

Esses dados permitem passar à próxima categoria aventada por C. Neal Tate: a existência de "instituições majoritárias inefetivas", isto é, incapazes de reunir em torno de si apoio público suficiente para defender suas escolhas diante de possíveis ataques desferidos pelo Poder Judiciário.

Essa condição estaria também presente na experiência brasileira? Responder essa questão exige tratar o problema das "instituições majoritárias inefetivas" em conjunto com o tema seguinte, ou seja, exige considerar esse problema tendo em vista a existência, ou não, de uma percepção geral negativa quanto às instituições originalmente responsáveis pela formulação de políticas públicas, oriunda de possíveis receios públicos quanto a práticas de clientelismo, personalismo, corrupção ou outras assemelhadas.

\footnotetext{
${ }^{163}$ Idem. Todos esses dados constam de tabela impressa na p. 60 do trabalho.

164 Idem, ibidem.
} 
Para que a pergunta formulada acima possa ser respondida afirmativamente, é preciso que os dados da realidade mostrem uma considerável descrença da população brasileira em suas instituições majoritárias, aliada a um voto de confiança ao menos substancialmente maior dado às instituições judiciárias nacionais. Isso parece, de fato, ocorrer.

(Tabela 02)

AÇÕES DIRETAS DE INCONSTITUCIONALIDADE POR REQUERENTE

\begin{tabular}{|c|c|c|c|c|c|c|c|c|c|c|c|c|c|c|c|c|c|c|c|c|}
\hline Presidente da República & 0 & 0 & 0 & 0 & 0 & 0 & 0 & 0 & 0 & 0 & 0 & 0 & 0 & 0 & 0 & 0 & 0 & 0 & & $0,00 \%$ \\
\hline Mesa do Senado Federal & 0 & 0 & 0 & 0 & 0 & 0 & 0 & 0 & 0 & 0 & 0 & 0 & 0 & 0 & 0 & 0 & 0 & 0 & & $0,00 \%$ \\
\hline Mesada A ssembeáa Legislativa & 0 & 1 & 1 & 7 & 4 & 1 & 1 & 3 & 2 & 2 & 1 & 3 & 4 & 3 & 3 & 1 & 0 & 1 & 38 & $1,14 \%$ \\
\hline Governador de Estado & 2 & 55 & 100 & 57 & 47 & 39 & 32 & 61 & 25 & 60 & 28 & 48 & 68 & 58 & 49 & 66 & 53 & 11 & 859 & $25,73 \%$ \\
\hline Frocunador-GeraldaRepública & 0 & 22 & 63 & 65 & 63 & 49 & 68 & 47 & 12 & 38 & 27 & 18 & 22 & 11 & 6 & 117 & 92 & 15 & 735 & $22,01 \%$ \\
\hline Partido Político & 2 & 14 & 30 & 39 & 25 & 15 & 29 & 47 & 47 & 45 & 42 & 59 & 75 & 79 & 27 & 44 & 41 & 3 & 663 & $19,86 \%$ \\
\hline Confederacäo Sindical ou Entidade de Classe & 4 & 53 & 51 & 58 & 21 & 48 & 64 & 48 & 59 & 47 & 69 & 46 & 62 & 51 & 35 & 52 & 78 & 12 & 858 & $25,70 \%$ \\
\hline Qutros & 2 & 9 & 1 & 3 & 2 & 3 & 1 & 3 & 5 & 2 & 5 & 3 & 2 & 1 & 1 & 0 & 5 & 6 & 54 & $1,62 \%$ \\
\hline TOTAL & 11 & 159 & 255 & 232 & 166 & 162 & 198 & 211 & 158 & 206 & 181 & 189 & 253 & 209 & 135 & 289 & 276 & 49 & 3.339 & $100,00 \%$ \\
\hline
\end{tabular}

(Fonte Tabela publicada originalmente no website do Supremo Tribunal Federal, sessão "Banco Nacional de Dados do Poder Judiciário" - http://www.stf.gov.br/bndpj/stf/AdinTotal.asp. Última consulta em 18 de março de 2005

Para ilustrar esse ponto, está reproduzido com algumas adaptações, na Tabela 03, um quadro apresentado por José Eduardo Faria em trabalho datado de 2003, referindo o índice de confiança da população brasileira em suas principais instituições. ${ }^{165}$

(Gráfico 01)

AÇÕES DIRETAS DE INCONSTITUCIONALIDADE POR REQUERENTE

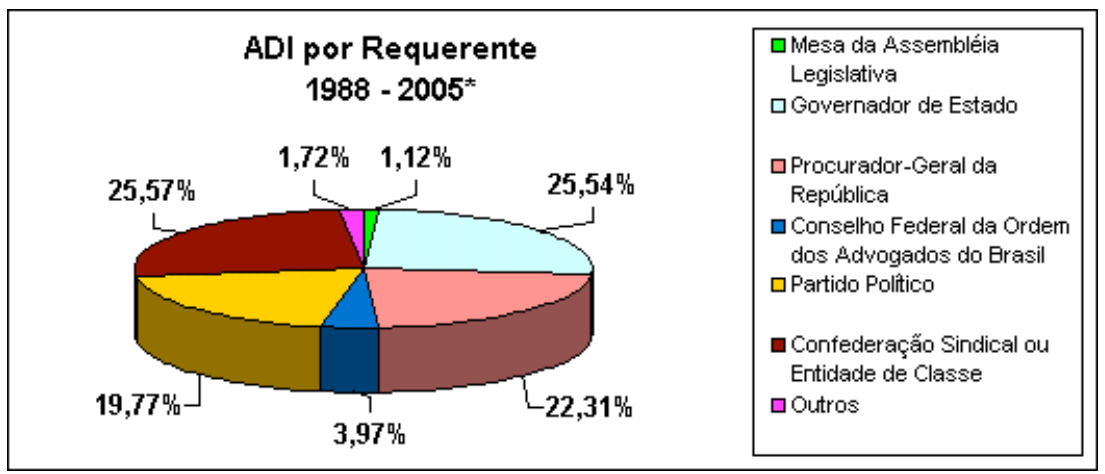

(Fonte Supremo Tribunal Federal, sessão "Banco Nacional de Dados do Poder Judiciário" - Gráfico disponível em http://www.stf.gov.br/bndpj/stf/AdinTotal.asp. Última consulta em 18 de março de 2005.

${ }^{165}$ Cf. José Eduardo Faria, Direito e Justiça no Séc. XXI: A crise da Justiça no Brasil. 
É verdade que, naqueles idos de 1999, pouco mais de metade da população pesquisada afirmava confiar no judiciário brasileiro. Todavia, em termos comparativos, o número assume expressão diferente. Percebe-se da tabela supra que o índice de confiança no judiciário é 11 vezes maior que o índice de confiança nos políticos em geral, 5 vezes maior que o índice de confiança nos partidos políticos e quase 4 vezes maior que o índice de confiança no Congresso Nacional. Entre as instituições pesquisadas, a Justiça só perde em confiabilidade para a Igreja Católica e (em apenas três pontos percentuais) para a mídia.

(Tabela 03)

ÍNDICE DE CONFIABILIDADE DAS INSTITUIÇÕES

(Percentual das respostas positivas quanto à confiabilidade das respectivas instituições, em 1999)

$\begin{array}{lr}\text { Igreja Católica } & 76 \% \\ \text { Meios de comunicação } & 58 \% \\ \text { Justiça } & 55 \% \\ \text { Sindicatos trabalhistas } & 49 \% \\ \text { Empresariado } & 45 \% \\ \text { Militares } & 35 \% \\ \text { Congresso } & 14 \% \\ \text { Partidos } & 11 \% \\ \text { Políticos } & 5 \%\end{array}$

(Fonte: Ibope, 1999, citado por José Eduardo Faria, Direito e Justiça no Séc. XXI: A crise da Justiça no Brasil, paper preparado para o seminário "Direito e Justiça no Século XXI", realizado em Coimbra, pelo Centro de Estudos Sociais, entre 29 de maio e 1 de junho de 2003)

Esses dados ajudam a explicar a enorme dificuldade que o governo brasileiro tem enfrentado, de fato, para sustentar boa parte de suas políticas públicas frente aos respectivos questionamentos judiciais, sobretudo quando essas políticas são de impacto menor e não se subsumem às grandes reformas estruturais da máquina estatal. ${ }^{166} \mathrm{Um}$

${ }^{166}$ Há um número razoável de estudos demonstrando que a probabilidade de uma dada política pública ser desafiada com sucesso no judiciário é inversamente proporcional à sua importância no que diz respeito à realização de grandes reformas macroscópicas na estrutura do Estado, especialmente caras ao grupo majoritário que se encontre em um dado momento no poder. V., a propósito, o clássico artigo de Robert Dahl, Decision-making in a democracy: the Supreme Court as a national policy-maker: "[A] lawmaking majority with major policy objectives in mind usually has an opportunity to seek for ways of overcoming the Court's veto. It is an interesting and highly significant fact that Congress and the president do generally succeed in overcoming a hostile Court on major policy issues "(Dahl afirma que o sucesso relativo das Cortes nas questões menores é decorrente da forma de preenchimento dos cargos na Suprema Corte Americana - indicações pelo Presidente, com a freqüência de uma a cada 2 anos, aproximadamente - o que permite, ocasionalmente, insurgências da Corte contra resquícios das políticas públicas implementadas por governos anteriores, mas nunca insurgências efetivas contra as principais políticas públicas do governo atual). V., tb., Lee Epstein, Jack Knight e Andrew Martin, The Supreme Court as a Strategic nacional policymaker (defendendo que o argumento de Dahl está correto, mas por uma outra razão: porque os membros da Suprema Corte decidem estrategicamente e, em função do equilíbrio de forças propiciado pela separação de poderes, jamais irão implementar decisões tão radicais a ponto de 
exemplo comezinho disso pode ser encontrado na política tributária do governo federal, que vem sofrendo, em bases tão escamoteadas quanto cotidianas, duros golpes desferidos pelo Poder Judiciário (para que se tenha uma idéia do volume desses processos, 9,49\% de todo o movimento do Supremo Tribunal Federal entre os anos de 1990 e 1999 envolveu matéria tributária ${ }^{167}$ ).

É certo que a comparação entre os índices de confiabilidade da Justiça e dos demais poderes do Estado faz crer que o Executivo e o Congresso tenham especial dificuldade em sustentar suas políticas diante de questionamentos feitos a elas pela sociedade civil, perante as instituições judiciárias. A literatura de ciência política sugere que tal conclusão deva ser tanto mais precisa quanto mais periféricas forem as políticas questionadas no que diz respeito às questões centrais atinentes à governabilidade. No Brasil, os dados disponíveis ainda são poucos, mas sugerem a confirmação da tese.

Em trabalho apresentado ao XX encontro anual da Associação Nacional de PósGraduação e Pesquisa em Ciências Sociais, Marcus Faro de Castro analisou 1.240 ementas de acórdãos julgados pelo Supremo Tribunal Federal e Publicados no Diário de Justiça da União no primeiro semestre de $1994^{168}$. A amostra compreendeu uma parcela significativa do total de 7.955 acórdãos publicados pelo tribunal no mesmo ano ${ }^{169}$ e revelou resultados interessantes. Em primeiro lugar, demonstrou que, na verdade, mais da metade dos processos analisados $(58,1 \%)$ veiculava questões de política fiscal ou tributária. ${ }^{170} \mathrm{Em}$ segundo lugar, mostrou também que, em mais de 3/4 dos casos $(75,5 \%)$, o tribunal produziu decisões totalmente contrárias aos interesses do Estado veiculados nos respectivos processos. Entre o universo de decisões contrárias aos interesses do Estado, a maior parte delas $(50,88 \%)$ dizia respeito, justamente, a temas de política fiscal e tributária ${ }^{171}$.

serem revertidas pelo Congresso; a ação estratégica dos membros da Corte os leva sempre a uma posição intermediária entre suas respectivas preferências e o grau de tolerância a elas do governo e do congresso, de modo que o resultado de sua ação seja ao mesmo tempo melhor do ponto de vista de suas preferências e não tão ruim, do pondo de vista das preferências concorrentes, a ponto de justificar ações retaliadoras por parte dos demais poderes).

167 Fonte: Banco Nacional de Dados do Poder Judiciário. Dados completos disponíveis no website do Supremo Tribunal Federal (http://www.stf.gov.br/bndpj/stf/RamoDireito.asp). Última consulta em $18 \mathrm{de}$ março de 2005.

${ }^{168}$ V. Marcus Faro de Castro, O Supremo Tribunal Federal e a judicialização da política, p. 147.

169 Idem, p. 151.

${ }^{170}$ Idem, p. 152.

171 Idem, p. 153. 
Outros temas semelhantes (alguns localizados mais no coração de certas políticas públicas fundamentais aos respectivos planos de governo dos ocupantes do poder central) poderiam ilustrar essa tese. Basta recordar a derrota sofrida pelo Governo em relação ao tema da correção monetária incidente sobre as contas de FGTS durante o período de 198990 (Plano Verão e Plano Collor) ${ }^{172}$, ou mesmo a batalha judicial que foi travada em torno da contribuição previdenciária dos inativos, da qual o governo saiu-se vencedor por apenas três votos de vantagem, e mesmo assim arcando com uma vitória parcial, já que o voto vencedor do Ministro Cezar Peluso manteve a constitucionalidade da política mas houve por bem aumentar o limite de isenção respectivo de $\mathrm{R} \$ 1.505,23$ para $\mathrm{R} \$ 2.508,72^{173}$.

Em todos esses casos, o governo ficou na difícil situação de ter que sustentar judicialmente medidas impopulares, as quais demandavam para sua implementação sacrifícios consideráveis por parte de setores importantes da sociedade civil, em um contexto no qual esses sacrifícios eram freqüentemente contrastados com afirmações de gastança generalizada, corrupção e prodigalidade no seio da própria administração federal.

A sétima condição descrita por C. Neal Tate para a eclosão de um processo nacional de judicialização da política consiste naquilo que ele chama de inércia proposital dos órgãos legislativos e executivos quanto ao trato de certas questões políticas delicadas, como ocorreria, nos Estados Unidos, com questões ligadas ao direito de aborto ${ }^{174}$ e, também, com o sistema carcerário em estados como o Texas. ${ }^{175}$ Segundo Tate, a omissão das instituições majoritárias nesses casos abriria mais uma porta para o trato desses mesmos temas por via judicial, consistindo em mais um motor para o processo de judicialização da política.

Esse é um tema mais próprio aos dilemas morais norte-americanos, formulados em termos de oposição dual (conservadores v. liberais). A correspondência com o caso brasileiro poderia ser, por isso, na melhor das hipóteses aproximada. Todavia, a recente

\footnotetext{
${ }^{172}$ Supremo Tribunal Federal, Recurso Extraordinário n. 226.855. Relator: Min. Moreira Alves. (DJ 13/10/2000).

173 Supremo Tribunal Federal, Ação Direta de Inconstitucionalidade n 3.105. Relatora: Min. Ellen Gracie. (DJ 18/02/2005).

174 A decisão judicial paradigmática nesse campo é aquela proferida no caso Roe v. Wade. V. 410 U.S. 113 (1973).

${ }^{175}$ Cf. C. Neal Tate, Why the expansion of Judicial Power, p. 32. V. tb., a respeito, Ben M. Crouch and James W. Marquart, An Appeal to Justice: Litigated Reform of Texas Prisons e Frank R. Kemerer, William Wayne Justice: A Judicial Biography.
} 
discussão travada no Supremo Tribunal Federal sobre o direito ao aborto ${ }^{176}$, aliada à posição bem pouco clara do governo Lula quanto ao assunto sugerem, também aqui, um paralelo importante. ${ }^{177}$

Tendo em conta as constatações referidas acima, alguém poderia dizer que o caso brasileiro reuniria todos os requisitos necessários a tornar-se um exemplo de manual em matéria de judicialização. E assim parece ser, efetivamente. $\mathrm{Na}$ experiência brasileira, as formas jurídicas por meio das quais são judicializados os conflitos políticos no pós-1988 evoluem do controle constitucionalidade das leis, marcado pelo caráter difuso e pela inexistência de jurisprudência vinculante, para desaguarem na interpretação e atuação de instrumentos normativos vagos, meramente enunciativos, em áreas próprias à regulação estatal. Isso, sobretudo por meio de ações de caráter coletivo.

\section{VI}

\section{A CRÍTICA À AÇÃo EXPANDIDA DO PODER JUDICIÁRIO}

Para finalizar esse panorama geral atinente ao processo de expansão das cortes de justiça no final do século passado, procuro apresentar, abaixo, como já referido anteriormente, as principais críticas que lhe são formuladas. Imagino, como dito, que essas críticas possam ser divididas em três categorias distintas.

Em primeiro lugar, destacam-se as críticas de legitimidade, que na experiência americana dizem respeito à chamada dificuldade contra-majoritária, assumindo, na experiência continental-européia, um viés legalista relacionado à interpretação dos postulados da separação de poderes.

Em segundo lugar, destaco aquela que chamo crítica institucionalista, própria, como visto, aos países em desenvolvimento.

\footnotetext{
${ }^{176}$ V. Ação de Descumprimento de Preceito Fundamental 54. Relator Min. Marco Aurélio.

177 Essa posição dúbia está clara, por exemplo, no teor da entrevista dada pela Dra. Nilcéa Freire (Secretária Especial de Políticas para Mulheres) ao programa Roda Viva, ocorrida em 21/03/2005. A todo o instante, a entrevistada insistia em caracterizar a posição do governo como interesse em fomentar o debate, apenas. Considerando tratar-se de um tema moral delicado, e que qualquer manifestação pró-aborto poderia minar a confiança no governo por parte de setores religiosos importantes, trata-se de um tema em que, claramente, a administração pública não quer avançar qualquer agenda específica.
} 
Finalmente, procuro circunscrever com um pouco mais de detalhes a crítica de capacidade instrumental, ou crítica instrumental. Esta última diz respeito, sobretudo, a uma dada concepção acerca daquilo que as cortes de justiça conseguem ou não conseguem fazer bem com o aparato instrumental que lhes é dado (inércia, independência do processo político, necessidade de fundamentação em base principiológica, instrumentos processuais ligados à solução retrospectiva de conflitos bilaterais, etc.). ${ }^{178}$

Não tentarei dar resposta a qualquer dessas ordens de crítica, mas, na segunda e terceira partes deste trabalho, tento demonstrar que a crítica instrumental toma por base um desenho historicamente circunscrito, mas não necessário, do aparato instrumental próprio às cortes de justiça.

Esse desenho é tributário da tradição liberal e funda-se em uma dada concepção de direito, que excluiu, historicamente, o bem comum como preocupação jurídica, assimilando todas as posições de vantagem protegidas pelo direito à figura do direito subjetivo. Tento mostrar que, em parte, o desajuste estrutural apontado pela crítica instrumental deve-se justamente à intensa relação existente entre essa específica concepção de direito e o desenho do arsenal de trabalho utilizado pelas cortes de justiça. Sobretudo na terceira parte, tento mostrar que, na experiência brasileira, a reintrodução do bem comum como um problema jurídico, alterando a concepção de direito acima formulada, redundou, também, em paulatina transformação, sobretudo no plano coletivo, do desenho institucional e do aparato instrumental das cortes de justiça e do processo judicial.

178 Esse tipo de crítica faz referência, no mais das vezes, a um certo modelo ideal de contencioso judicial, no qual procura encaixar a solução de conflitos policêntricos, anotando as perplexidades correspondentes. Essa linha de argumento será explorada mais adiante. Há, contudo, uma linha mais empírico dessa crítica, sobretudo no campo da ciência política. São trabalhos que partem menos de um tipo ideal de justiça que da observação de certos casos práticos de envolvimento judicial em políticas públicas. Exemplos disso são os livros de Donald Horowitz (The Courts and Social Policy) e, sobretudo, Gerald N. Rosenberg (The Hollow Hope: Can Courts Bring About Social Change?). Segundo afirma Rosennberg, baseado em estudos empíricos descritos em seu livro, os tribunais seriam, na experiência americana, agentes intrinsecamente inefetivos de mudança social, sobretudo em virtude da natureza limitada dos direitos constitucionalmente assegurados, do baixo nível de independência dos juízes e da ausência de capacidade de impor, por força própria, suas decisões. Algum grau de mudança social somente poderia ser operado pelos tribunais na medida em que houvesse um contexto legal anterior propício à mudança, apoio à mudança por parte de expressiva porção do congresso e das agências de governo, e expressivo apoio popular, ou, ao menos, ausência de oposição popular. Além disso, seria preciso haver incentivos externos e positivos ao cumprimento da decisão judicial respectiva, ou custos importantes decorrentes de seu descumprimento, ou a reserva de um espaço mais ou menos flexível para cumprimento da decisão (idem, p. 35-36). A crítica de Horowitz será explorada em mais detalhes na segunda parte do trabalho. 
Para finalizar, pois, o panorama proposto, inicio com a referência à crítica americana de legitimidade. Ela pode ser exemplificada com a citação de alguns trechos de uma reportagem publicada na revista The Economist em 8 de dezembro de 2005 ( $A$ Heretical Proposal):

"A maior parte dos outros países desenvolvidos resolveu o problema do direito ao aborto consultando seu eleitorado - seja através de processo legislativo, seja por meio de referendos. Isso levou a debates vigorosos e, em geral, ao triunfo do direito ao aborto. Por ter sido legalizado democraticamente, os seus opositores passaram a aceitar a derrota muito mais facilmente e o direito ao aborto tornou-se uma liberdade consagrada definitivamente. Ao revés, nos Estados Unidos, o aborto é considerado parte do direito fundamental à privacidade, sendo assim protegido por uma decisão de 1973 proferida pela Suprema Corte Americana — Roe v Wade.

Poucos observadores imparciais - se é que pode haver isso em matéria de aborto - se sentiriam à vontade para dizer que a confiança nos juízes em substituição à vontade popular ajudou a política americana: nenhum outro país semelhante experimentou uma guerra moral tão destrutiva. Roe deixou em uma vasta porção do país um sentimento de privação, pela corte, de seus direitos políticos e de opinião; a decisão também iniciou um ciclo de ataques e contraataques que degradou tudo aquilo em que tocou, especialmente o judiciário.” (...)

"Tudo isso é ruim para os Estados Unidos; mas, em termos políticos, Roe é uma decisão particularmente desastrosa para os Democratas. (...) Por que diabos os Democratas não renegam Roe?"

(...)

"Abraçar o processo democrático mandaria um poderoso sinal no sentido de ter o partido redescoberto sua confiança no povo.”

Não é totalmente verdadeiro que "a maior parte dos outros países desenvolvidos" tenha resolvido "o problema do direito ao aborto consultando seu eleitorado", como sugere a reportagem, de vez que decisões parecidas com Roe v. Wade marcaram o processo político de legalização do aborto em países importantes como a Áustria, França e a Itália. Com resultado inicialmente inverso, a questão também conheceu apreciação judicial na Alemanha. ${ }^{179}$ No entanto, é possível identificar, no texto acima, o problema fundamental da crítica contra-majoritária: confiar aos juízes a definição das questões políticas centrais a

\footnotetext{
${ }^{179}$ V. Mauro Cappelletti, The Mighty Problem..., p. 423. Ressalvo a existência de decisões posteriores sobre o assunto por parte da Corte alemã, com orientação parcialmente diferente. Como elas ainda não existiam na época em que Cappelletti escreveu seu texto, ele, obviamente, não as inclui.
} 
uma sociedade significa, em última análise, desconfiar da capacidade da própria sociedade de determinar-se.

O princípio majoritário tem um apelo político inegável. É consagração direta da regra racional de igualdade: a cada pessoa, um voto. Por isso, desde sempre o controle de constitucionalidade de leis (e, mais genericamente, o ativismo judicial traduzido em invalidação e modificação de decisões parlamentares e executivas) conheceu, nos Estados Unidos, crítica importante. As palavras de Robert Dahl, já citadas anteriormente, são prova disso. ${ }^{180} \mathrm{Na}$ mesma medida, um dos textos mais influentes da teoria constitucional americana recente advoga uma profunda restrição do âmbito de incidência desse controle, com vistas a restringi-lo tão somente a "questões de participação", de sorte a não se atingir o "mérito substantivo das escolhas políticas sob ataque". ${ }^{181}$

Sem dúvida, após a decisão proferida no caso Roe v. Wade, as críticas de legitimidade ao ativismo da Suprema Corte americana aumentaram consideravelmente. ${ }^{182}$ Não obstante, é também fato que a "supremacia parlamentar" que se esconde por trás da crítica de legitimidade perdeu, ao longo da segunda metade do século passado, bastante de sua força, como produto do processo de burocratização do Estado e do crescimento, nos Estados Unidos, do papel dos órgãos reguladores independentes.

Não é casual, nesse contexto, que uma crítica semelhante àquela que se dirigiu contra as cortes de justiça tenha sido levantada também em relação à legitimidade desses órgãos de regulação. Sua capacidade decisória, outorgada por meio de delegação legislativa, seria, portanto, uma outra forma de "abuso" praticada contra a população. ${ }^{183}$ Nesse contexto, Cappelletti parece ter razão ao afirmar que o movimento de expansão das cortes de justiça a partir da segunda metade do século passado não representa senão $u m$ dos aspectos de um movimento mais geral, relativo à própria expansão do Estado e complexificação de sua burocracia. ${ }^{184}$

\footnotetext{
${ }^{180}$ V., a propósito, o texto que acompanha a nota 98, acima.

${ }^{181}$ Cf. John Hart Ely, Democracy and Distrust, passim.

${ }^{182}$ V. Mauro Cappelletti, The Mighty Problem.., p. 438. V. tb. William N. Eskridge, Jr., Pluralism and Distrust: How Courts Can Support Democracy by Lowering the Stakes of Politics.

${ }^{183}$ V. David Schoenbrod, Power Without Responsability: How Congress abuses the people through delegation.

${ }^{184}$ Cf. Mauro Cappelletti, The Mighty Problem.., p. 438.
} 
$\mathrm{Na}$ tradição européia, da qual o direito nacional é tributário, essa questão geralmente coloca-se em termos diversos, transportando-se para a esfera da interpretação do princípio de separação de poderes. Sob essa ótica, o problema relativo ao controle de constitucionalidade perde bastante de seu interesse, uma vez que, em geral, nos ordenamentos que o aceitam a partir da tradição austríaca, aceita-se também que seja papel constitucional das cortes de justiça respectiva exercê-lo. Utilizando-se de um raciocínio muito parecido com aquele formulado pela Suprema Corte americana em Marbury v. Madison $^{185}$, traduzido, por sua vez, sob a ótica do positivismo kelseniano formulado no início do século (lembre-se que foi Kelsen o responsável pela redação da Constituição austríaca), essa tradição não vê oposição, em geral, entre constitucionalismo e vontade popular, na medida em que a própria Constituição é expressão da vontade popular.

No Brasil, a discussão coloca-se de forma muito semelhante a essa. Como regra, o alvo principal de ataque ao ativismo judicial costuma ser a intervenção sobre o domínio administrativo. Mas é verdade que se deixa de perceber, assim, o efetivo problema contramajoritário, sobretudo no contexto de uma Constituição que se expressa por meio de um texto aberto, positivando princípios contraditórios, cuja interpretação pode redundar em quase qualquer tipo de decisão. ${ }^{186}$

Como dito acima, no contexto latino-americano essa crítica de legitimidade cede espaço sobretudo à crítica institucional. Assim, exagerando e caricaturizando o argumento, em países em desenvolvimento a contenção judicial seria justificável menos como um imperativo de democracia e mais como uma necessidade de atração de investimentos. $\mathrm{O}$ ativismo, nesse contexto, produz menos danos pelo desrespeito à vontade majoritária que pela insegurança que agrega ao ambiente econômico. Um bom Judiciário deveria ser

185 "It is emphatically the province and duty of the judicial department to say what the law is. Those who apply the rule to particular cases, must of necessity expound and interpret that rule. If two laws conflict with each other, the courts must decide on the operation of each. So if a law be in opposition to the constitution: if both the law and the constitution apply to a particular case, so that the court must either decide that case conformably to the law, disregarding the constitution; or conformably to the constitution, disregarding the law: the court must determine which of these conflicting rules governs the case. This is of the very essence of judicial duty."

186 Sobre o problema da interpretação de textos abertos, há extensíssima literatura. Uma parte interessante dela está representada nos debates travados entre Stanley Fish, Ronald Dworkin e Owen Fiss. V., a respeito Stanley Fish, Fish v. Fiss, Working on the Chain-Gang..., Interpretation and the Pluralist Vision e , Is There a Text in this Classroom?; Owen M. Fiss, Conventionalism e Objectivity and Interpretation; Ronald Dworkin, Law as Interpretation. V. tb. Thomas Nagel, Objectivity, in Mortal Questions, Cambridge, Cambridge University Press, 1992. 
previsível e a justiça brasileira, por exemplo, não parece apresentar esse quesito, diz um importante estudo organizado por Armando Castelar Pinheiro. ${ }^{187}$

Esse elemento de previsibilidade é, para o argumento institucionalista, crucial. Relações econômicas duradouras dependem fundamentalmente de um sistema legal previsível, que garanta o cumprimento dos contratos, e também de um aparato judicial eficiente, que trabalhe em conjunto com o sistema de regras jurídicas para garantir a pronta efetivação dos direitos. A ausência desses fatores pode levar ao caos econômico. Em geral, a Rússia tem sido utilizada como exemplo eloqüente disso. ${ }^{188}$

Ademais, a "privatização", processo pelo qual passaram recentemente a maior parte das economias em desenvolvimento, "exige instituições legais críveis e efetivas", conforme acentou Werner Wabnitz. O sucesso do trabalho do Banco Mundial de atração de investimentos em setores de serviços e infra-estrutura "depende, portanto, diretamente, de um sistema judiciário digno de credibilidade e (razoavelmente) eficiente". Um "sistema é

187 Armando Castelar Pinheiro (org.), Judiciário e Economia no Brasil.

188 "At a more basic level, the Russian case confirms that uncertainty can retard the development of longterm relationships, which, in turn, can facilitate litigation. Initially, Russian managers found freedom of contract exhilarating, but the thrill wore off as interenterprise arrears mounted. Not paying became the norm, and one's reputation seemed to be enhanced by an ability to pile on more and more debt without tipping over into bankruptcy. The ability to shirk debt became a source of pride rather than shame. Moreover, the efforts of creditors to prevent delinquency fell flat. In the absence of reliable credit rating agencies and/or a workable system of collateral, creditors were limited to demanding prepayment. But the existence of competitors willing to underbid on the percentage of prepayment required limited the ability of creditors to mitigate risk by insisting on full prepayment. Absent prepayment, only the existence of long-term relationships provided some minimal insurance that payment would be forthcoming. They came with a safety net of interpersonal relations among mid-level managers that had been forged over decades in oppressive conditions of constant material shortages. Not surprisingly, enterprises valued these long-term relationships and were loathe to risk them through litigation. Instead, they took their newer customers to court, reasoning that they had little to lose if the relationship soured, though most indicated in the interviews that they did not expect that outcome. Much like their counterparts in the United States in the late 19th century who did not have access to reliable credit ratings (Kagan 1984:339-40), contemporary Russian manufacturers have no choice but to sell their goods to new and untested customers and hope for the best. Like their predecessors, they use the courts aggressively to collect these debts. Whether the emergence of a more stable financial system will bring an end to the practice of bringing petty debts to the courts (as happened in the United States) remains to be seen. Looking beyond bilateral relationships, the distaste for litigation among some is no doubt motivated by the lingering skepticism toward law and legal institutions that persists as a legacy from the Soviet era. Notwithstanding the efforts at reform since the late 1980s, many enterprise managers remain openly dismissive of the capacity of the legal system to resolve disputes. The common wisdom that the courts are unusable reflects their contempt. Those who pursue legal remedies seem to do so without any expectation that they will actually collect the full amount owed, but with a sense that a lawsuit may marginally improve their chances of collecting some fraction of it. The low levels of voluntary compliance with the judgments of arbitrazh courts speak vividly to the lack of respect of most litigants for these courts. In such an environment, going to court is inevitably just one of a multitude of strategies that enterprises employ to encourage their customers to pay their debts." Cf. Kathryn Hendley, Business Litigation in the Transition: A Portrait of Debt Collection in Russia. 
mais que a lei: não é o texto legal que faz a diferença... mas a capacidade do sistema judicial de decidir e fazer cumprirem-se as suas decisões". ${ }^{189}$

A crítica institucional, arrisco dizê-lo, parece vir dando a tônica das reformas que têm sido implementadas no Brasil. Isso fica claro quando é observada a redação das primeiras sentenças do "Pacto de Estado em Favor de um Judiciário Mais Rápido e Republicano", assinado pelos presidentes da República, do Supremo Tribunal Federal, do Senado Federal e da Câmara dos Deputados, e publicado do Diário Oficial da União de 16 de dezembro de 2004, seção I pág. 8. Segundo esse texto, “A morosidade dos processos judiciais e a baixa eficácia de suas decisões retardam o desenvolvimento nacional, desestimulam investimentos, propiciam a inadimplência, geram impunidade e solapam a crença dos cidadãos no regime democrático".

O documento assinado conjuntamente pelos três poderes não relaciona, evidentemente, o tema do ativismo com o tema dos investimentos. Também não o fazem as reformas mais recentes no aparato processual e no modelo constitucional da Justiça ${ }^{190}$. Não obstante, essa relação é presente e delicada. Ela pode ser exemplificada pela reação da imprensa, em meados de 2003, às várias decisões judiciais que, ao amparo das provocações originadas pelo Ministro Miro Teixeira, impediram as empresas ligadas à telefonia fixa de implementar os reajustes tarifários então autorizados pela Agência Nacional de Telecomunicações. Confira-se, a propósito, o seguinte artigo publicado por João Mellão

189 "In the 1990's the Bank progressively reached the conclusion that the private sector would be the engine of economic growth, which the state and its enterprises had failed to deliver. However, privatization is not intended as final objective. Neither the free market economy assumed to be the best economic model. Both are supposed to foster fair competition. Fair competition, in turn, is supposed to reduce productionand service costs, (without hurting labor beyond acceptable levels) which in turn would reduce prices, spread the accessibility of goods and services among the population and thereby foster economic development and reduce poverty. But fair competition requires rules, standards for acceptable behavior. Such rules need, to be observed, an arbiter able and willing to enforce them. This is crucial in an economic setting where the accepted motive is efficiency in making money (not w/o truth is the God of commerce and thieves the same in ancient Greece). The success of the investment work of the Bank - in plant and in the service sectors - therefore depends directly on a credible and (fairly) efficient judicial system in its member countries. A "system" is more than a law: it is not the text of a law which makes a difference (too often not available and ignored), it is the capacity of the judicial system to decide, and to enforce its own decisions. So the Bank came to assist in, and finance legal and judicial reform as an appendix to its economic work. " Cf. Hans-Werner Wabnitz, Access to Court: Examples of World Bank Projects which Include Activities to Facilitate Access to Court.

${ }^{190}$ O mesmo não pode ser dito das reformas silenciosas empreendidas anteriormente pelo governo Fernando Henrique Cardoso, sobretudo destinadas a dificultar a concessão de liminares em face do poder público, a impedir a utilização de ações coletivas em matéria fiscal e previdenciária e a estender as hipóteses de suspensão de liminares por parte dos tribunais superiores. Estas, de que irei tratar na terceira parte deste trabalho, consistiram, evidentemente, em respostas ao ativismo judicial pós-privatizações. 
Neto na edição de 18 de julho de 2003 do jornal O Estado de São Paulo (Até futebol tem regras):

"Os detalhes do episódio chegam à opinião pública nacional e, pior, à internacional também. Os contratos, quando firmados, previam um índice de reposição de preços, a ser aplicado anualmente. Como na exuberante economia brasileira há dezenas de índices diferentes, a Anatel, à época, escolheu o IGP-DI, que era o que apontava uma inflação menor. O IPCA, nem pensar. Era o vilão daqueles tempos. Os gringos concordaram com o índice proposto e assim foram assinados todos os contratos.

O tempo passa e os índices mudam. Não é que o IGP-DI deu de subir mais do que o IPCA? Quando chegou julho, o mês dos reajustes, os gringos, candidamente, na suposição de que este seja um país sério, aplicaram o índice pactuado nas tarifas. Gritaria geral. Miro, o grande, o campeão dos preços baixos, se rebela. Não está sozinho. Acionados pelo Ministério Público, vários juízes federais surpreendem o País com seus insuspeitados conhecimentos de economia e passam a conceder liminares contra o reajuste.

Um deles, mais douto que os demais, prolata uma sentença em que simplesmente substitui os índices. Onde valia o IGP-DI, passa a valer o IPCA e ponto final.

Até aí, as empresas concessionárias acreditavam que tudo não passava de desvios populistas de meia dúzia de magistrados de província. Qual não foi a surpresa quando o presidente do Superior Tribunal de Justiça, a penúltima instância judicial da Nação, deu razão ao tal juiz que trocou os índices. A questão ainda vai ao plenário do STJ. Liminarmente fica valendo a decisão daquele criativo magistrado.

Subdesenvolvimento não se improvisa - já dizíamos no início -, é obra de séculos e de muitos, também. E o Poder Judiciário, como neste caso, por vezes colabora. Com base em qual princípio do Direito, um juiz se julga competente para intervir num ato juridicamente perfeito? Pior: ele não só intervém como se entende apto a julgar qual o índice de reajuste de preços é o mais "justo" no caso. E é referendado por um tribunal superior!

Minha opinião, bem sei, não é das mais simpáticas. Afinal, todos preferem um reajuste menor. Mas o que está em jogo, aqui, não é o porcentual ou o índice de preços. É a credibilidade do Brasil enquanto parceiro sério na economia internacional. Nós não podemos simplesmente rasgar contratos quando eles nos desfavorecem. Mesmo com um inconseqüente aval da nossa Justiça.

O que, por exemplo, ocorreria no futebol, se os nossos árbitros se dispusessem a ir mudando as regras do jogo conforme o desenrolar da partida?

Com certeza nenhum país se disporia a jogar conosco.

Isso é ainda mais verdadeiro quando o jogo é a dinheiro. Na economia internacional só entram em campo os times que se propõem a jogar a sério. E isso implica respeitar religiosamente os contratos. Mormente quando estes são livremente estabelecidos entre as partes. 
Se o Brasil fosse um país tão rico a ponto de poder ignorar o capital estrangeiro, se o Estado brasileiro tivesse condições de suprir todas as necessidades de infra-estrutura nacionais a ponto de poder repudiar investimentos internacionais, então, estaria tudo bem. Lançaríamos os gringos ao mar e viveríamos em paz, soberanamente usufruindo nossas inesgotáveis riquezas.

Mas parece que não é bem esse o caso. Enquanto o nosso bravo Miro rasga contratos na área das comunicações, a ministra Dilma se descabela porque não consegue atrair investidores privados para a geração de energia. Também, pudera! Só os nossos briosos magistrados não se dão conta de que há uma íntima relação entre uma coisa e outra."

Quase um ano mais tarde, foi exatamente esse argumento, baseado na crítica institucional, que acabou por sensibilizar o Ministro Edson Vidigal, do Superior Tribunal de Justiça, a alterar a decisão original de revisão dos critérios de reajuste tarifário. Seu voto conduziu o acórdão respectivo nos seguintes termos:

“...em um primeiro e superficial exame, próprio dessa fase procedimental, vejo caracterizado o risco inverso, refletido no cenário de insegurança jurídica que se instala, na medida em que a manutenção da liminar, que, em princípio, admite a quebra do equilíbrio dos contratos e despreza os vultosos investimentos feitos, pode sim causar perplexidade nos investidores, afastando-os, caos no sistema tarifário, a par de expor o país aumentando o risco Brasil e prejudicando o usuário que se buscou proteger, lesando a ordem pública administrativa."191

Considerando a tradição ligada à separação de poderes, acima referida, e os problemas ligados à falta de investimentos, a crítica institucional parece ser, portanto, no Brasil, substancialmente mais importante que a crítica de legitimidade. Mas, mais uma vez, retomo aqui minha proposta original de não dar a elas resposta neste trabalho. Tendo em mente as linhas gerais por que caminham essas críticas, passo, derradeiramente, à descrição inicial da crítica instrumental, que será mais intensamente abordada no restante do texto.

Resumidamente, essa crítica aponta a incapacidade do órgão judiciário de lidar com conflitos políticos, fundando esse juízo na inadequação dos instrumentos de trabalho da justiça para essa tarefa. À inércia da jurisdição corresponderia, por exemplo, sua incapacidade de desenhar políticas públicas consistentes, uma vez que, considerada essa característica institucional, toda ação judiciária é necessariamente reativa. Em outras palavras, o judiciário não teria como identificar as necessidades sociais para adaptar a elas suas políticas, o que seria argumento mais que bastante a justificar seu afastamento dessa seara.

${ }^{191}$ Superior Tribunal de Justiça, AgRg na Suspensão de Liminar No 57 - DF (20040004599-1). 
Ademais, os conflitos políticos seriam "policêntricos", ao passo em que a estrutura do processo judicial, com autor, juiz e réu (a tríade), apenas comportaria adequadamente a resolução de conflitos de natureza bilateral.

A necessidade de fundar suas decisões em princípios legais preexistentes retiraria da solução judicial a necessária flexibilidade para atuar politicamente. Em política, os raciocínios e soluções devem ser basicamente prospectivos e conseqüencialistas, ao passo em que as decisões judiciais são retrospectivas e principiológicas, diria ainda essa mesma crítica. A mesma rigidez adviria dos regimes jurídicos da adstrição da sentença ao pedido e da coisa julgada. Por força desses princípios, o judiciário somente estaria apto a implementar ou deixar de implementar a solução política propugnada pelo autor, quando, em política, é a via di mezzo, obtida por meio da barganha, a que geralmente se mostra mais efetiva. Ademais, a coisa julgada impediria a progressiva adaptação das soluções ao contexto social em que elas atuam, característica essa também essencial à ação política.

$\mathrm{Na}$ parte seguinte, tento descrever essa crítica em maiores detalhes, mostrando, ainda, que ela se refere a uma concepção de direito que não é necessária, mas que coincide, sobretudo, com o surgimento do liberalismo e do projeto moderno. Tentarei mostrar que essa crítica instrumental pode ser iluminada pelas idéias de distribuição e comutação e que sua razão de ser está, sobretudo, na visão do órgão judiciário como um implementador de direitos subjetivos, papel esse que está, presentemente, em franca transformação. 


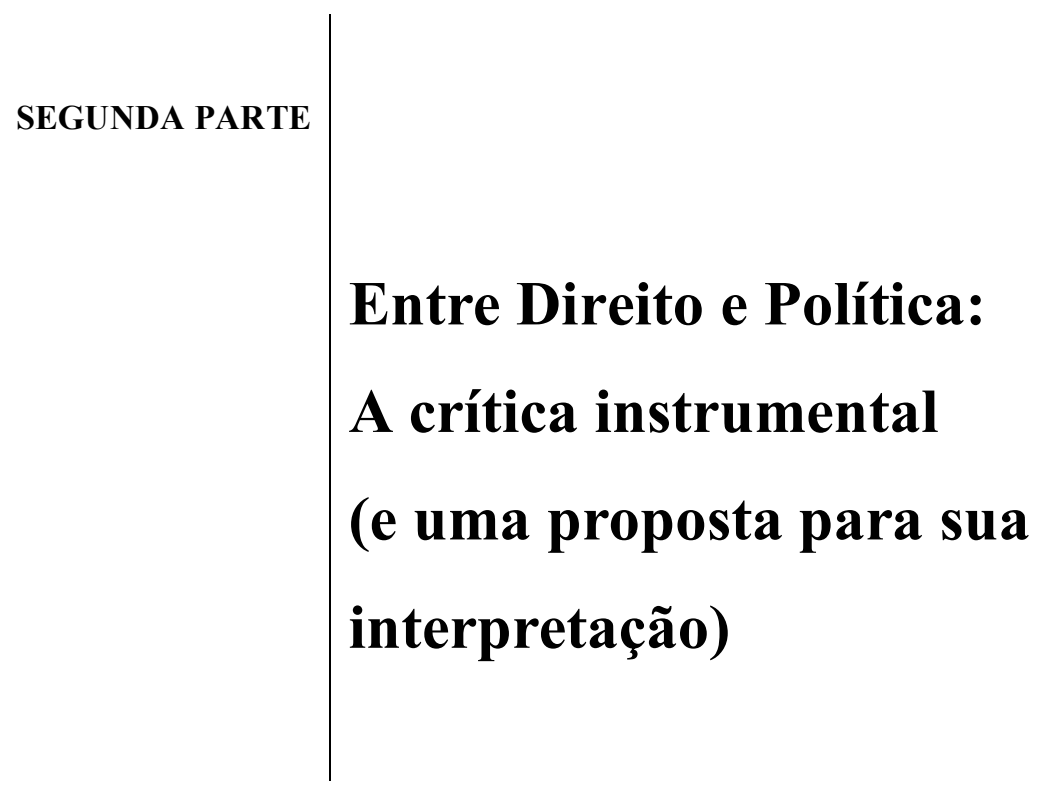

Aquela que estou chamando aqui de crítica instrumental baseia seu argumento, como visto na primeira parte, em uma certa análise das características institucionais típicas dos órgãos judiciários, relativas, umas, à própria estruturação desses órgãos, e, outras, ao arsenal de instrumentos de que eles podem lançar mão para desenvolver seu trabalho (resumidamente, o processo judicial).

Como visto, a crítica instrumental questiona a capacidade dos órgãos judiciários de lidar com questões políticas, ou mesmo de produzir mudança social ordenada, em vista de suas próprias características institucionais (ou, como prefiro dizer, dos instrumentos de trabalho típicos colocados à disposição dos órgãos judiciários).

Creio que um bom ponto de partida para exemplificar o argumento da crítica instrumental seja o texto clássico de Lon Füller, The Forms and Limits of Adjudication, que introduz, substancialmente, o problema do policentrismo dos conflitos políticos. ${ }^{192}$ Füller aborda, em seu texto, as dificuldades que o esquema bilateral do processo judicial enfrenta para conta dessa estrutura amorfa e dispersa própria às questões políticas, aos conflitos que, por isso, deveriam ser resolvidos por legislação, não por adjudicação. No item I, adiante, inicio pela abordagem desse trabalho.

19292 Harv. L. Rev. 353 (1978-1979). 
Mais adiante no mesmo item, às considerações de Füller serão acrescentadas as de dois outros autores que selecionei como representativos de vertentes distintas da crítica instrumental: Donald L. Horowitz e José Ignácio Botelho de Mesquita. Referindo-me a eles, procuro circunscrever em suas vertentes essa crítica e apontar-lhe os caminhos principais.

Os itens II e III adiante tentam localizar a crítica instrumental no "espaço e no tempo", mostrando como ela parece dirigir-se, sobretudo, a um certo modelo de justiça, modelo esse que vem sendo, paulatinamente, substituído por outros.

No item final desta parte (item IV) procuro apresentar algumas das respostas que têm sido oferecidas pela literatura à crítica instrumental, as quais antecipam, parcialmente, os caminhos que vêm sendo percorridos pelo direito positivo brasileiro em resposta aos desafios que lhe são apresentados pelo processo de judicialização da vida pública nacional. Esses caminhos são discutidos na terceira e última parte do trabalho.

\section{I}

OS “LIMITES” DO CONTENCIOSO JUDICIAL

No texto há pouco referido (The Forms and Limits of Adjudication), Lon Füller trabalha a partir da idéia de adjudicação ${ }^{193}$. Em seu artigo, ele procura defini-la da forma mais ampla possível, de sorte a compreender fenômenos tão distintos quando o arbitramento, pelo pai, da disputa entre duas crianças pela posse de um brinquedo, ou o julgamento, no Senado americano, do processo de impeachment do Presidente, ou a decisão de uma disputa internacional por parte de um tribunal supranacional. ${ }^{194}$ A adjudicação, assim amplamente considerada, poderia ser tida como uma "forma de

\footnotetext{
${ }^{193}$ V. nota anterior. Note-se que, apesar da publicação em 1978, o texto é, na verdade, da década de 1950. Sua primeira versão foi divulgada em 1957 e uma versão expandida foi utilizada por Füller em seu curso de teoria jurídica em Harvard em 1959. Trata-se, portanto, de uma clara resposta a Brown v. Board of Education, julgado em 1954, ainda que o caso não seja citado nem uma única vez por Füller. A partir dessas versões preliminares, de circulação informal, o texto tornou-se, no meio acadêmico americano, bastante influente. A efetiva publicação só ocorreu postumamente.

${ }^{194}$ Idem, p. 353.
} 
ordenação social, por meio da qual as relações de um homem com outro são reguladas" ${ }^{\text {"195 }}$. Füller procura comparar a adjudicação com outras "formas de ordenação social", sobretudo o "contrato" e "as eleições", consistentes em formas de organização por reciprocidade e organização por objetivos comuns ${ }^{196}$. Com esse intento, procura descobrir os limites da adjudicação como forma e ordenação social, definindo, pois, a "verdadeira adjudicação", ou a adjudicação como ela "deveria ser, caso os ideais que a suportam fossem realizados em sua plenitude". ${ }^{197}$

A adjudicação, o contrato e as eleições são "três formas de alcançar decisões, resolver disputas, definir as relações de um homem com outro". Todavia, cada qual funcionaria de acordo com um modelo de participação distinto, no que se refere às partes afetadas pela decisão. O modelo próprio do contrato seria a negociação. O modelo das eleições o voto. $\mathrm{O}$ da adjudicação seria a apresentação de provas e argumentos racionais. ${ }^{198}$

A característica básica da adjudicação é, pois, seu meio de participação (apresentação de provas e argumentos para uma decisão a favor da parte que os apresenta). Para Füller, tudo o que potencializa o significado desse modo de participação otimiza a adjudicação como meio de ordenação social. Tudo o que se afasta desse modelo destrói a integridade do processo adjudicativo (parcialidade do juiz, propina, irracionalidade, etc.). ${ }^{199}$

A questão da racionalidade também é central para Füller. Segundo ele, a adjudicação é essencialmente racional, ao passo em que o voto pode ser emocional. A negociação, por sua vez, é racional, mas tem uma racionalidade diferente, a do interesse ("troca de batatas por cebolas") ${ }^{200}$. A adjudicação é baseada em direitos, não em interesses. Isso não é necessário, mas é conseqüência de sua estrutura (provas e argumentos). O que quer que se submeta à adjudicação tende a converter-se em uma briga sobre direitos. ${ }^{201}$

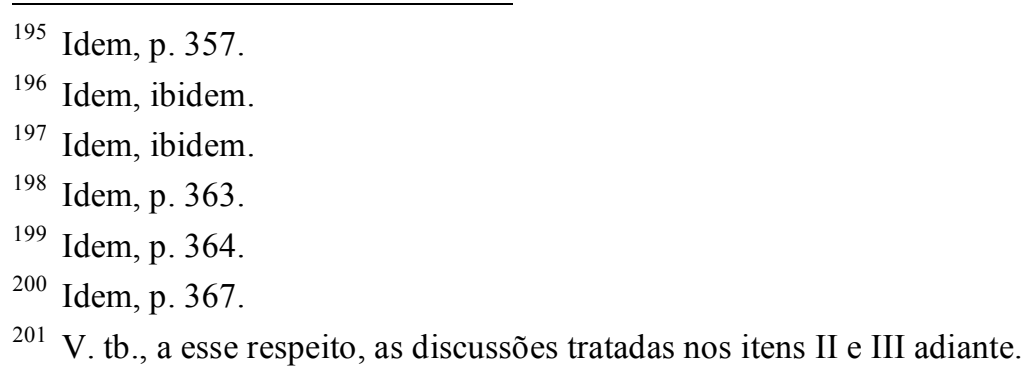


Em suas palavras, “a adjudicação é, portanto, o mecanismo que dá expressão formal e institucional à influência do argumento racional nos negócios humanos. Como tal ela assume um ônus de racionalidade não suportado por qualquer outra forma de ordenação social. Uma decisão que é produto do argumento racional deve estar preparada para passar no teste da razão. Nós exigimos da decisão adjudicatória um tipo de racionalidade que não esperamos resultar de um contrato ou do voto. Essa tendência maior em direção à racionalidade é, simultaneamente, a força e a fraqueza da adjudicação como forma de ordenação social". ${ }^{202}$ A participação em processos decisórios por meio do voto, por exemplo, é, em última análise, "inarticulada, emocional e não está sujeita a defesa com base na racionalidade". 203204

Seguindo em seu modelo, Füller aponta que a adjudicação tem um viés retrospectivo, ao passo em que o processo legislativo, por exemplo, olha para o futuro. $\mathrm{O}$ objetivo da adjudicação não é o de estabelecer direitos, mas o de verificar se os direitos já estabelecidos foram ou não respeitados em uma dada relação bilateral (ainda que, ao fazer esse trabalho retrospectivo, o processo adjudicatório possa, naturalmente, acabar ajudando a esclarecer a extensão dos direitos previamente reconhecidos). Uma das principais razões para essa natureza retrospectiva reside, por sinal, no próprio modo de participação peculiar ao processo adjudicativo. ${ }^{205}$

${ }^{202}$ Lon Füller, The Forms and Limits of Adjudication, p. 366.

${ }^{203}$ Idem, p. 367.

${ }^{204} \mathrm{O}$ caráter errático da escolha política tradicional, apreendido por Füller a partir do comportamento individual do votante, é objeto de extensa literatura de ciência política. O famoso teorema de Arrow é exemplo disso. Sobre esse tema, v. Jon Elster, A Possibilidade da Política Racional. "Mais ainda do que nas decisões individuais, imperam nas decisões sociais a incerteza e a ignorância" (idem, p. 15). Elster, no entanto, procura mostrar como a noção de justiça tem fornecido, mais que a racionalidade instrumental, própria ao raciocínio econômico (maximização de bem-estar), a tônica da ação política no Estado Social. "Não acredito que as principais reformas políticas realizadas no último século tenham-se apoiado sobretudo em razões instrumentais; ao contrário, elas foram defendidas por movimentos sociais ancorados numa concepção de justiça" (idem, p. 28). Se Elster estiver correto, o modelo de Füller perde, então, boa parte de sua força, sobretudo normativa.

205 "The philosophy underlying the retrospective effect of the judicial decision can be stated somewhat as follows: It is not the function of courts to create new aims for society or to impose on society new basic directives. The courts for various reasons analyzed previously are unsuited for this sort of task. Perhaps the most compelling objection to an assumption of any such function lies in the limited participation in the decision by the litigants who (I) represent generally only themselves and (2) participate in the decision only by proofs and argumenta addressed to the arbiter. On the other hand, with respect to the generally shared aims and the authoritative directives of a society, the courts do have an important function to perform, that of developing (or even "discovering") case by case what these aims or directives demand for their realization in particular situations of fact. In the discharge of this function, at times the result is so obvious that no one thinks of a "retroactive effect." Theoretically, a court might distinguish between such decisions and those which announce a rule or standard that seerns "new," even though it may represent a reasoned conclusion from familiar premises. But if an attempt were made to apply such a distinction 
Segundo Füller, a adjudicação não é capaz de resolver problemas "policêntricos". 206 Esse autor procura explicar o que entende por isso através de alguns exemplos práticos.

No primeiro deles, uma senhora de nome Timken morre em Nova Iorque deixando uma coleção valiosa mas bastante heterogênea de pinturas ao Metropolitan Museum e à National Gallery, em iguais proporções, sem indicar, em seu testamento, quais obras deveriam ser encaminhadas a qual museu. Füller pergunta, então, o que faz desse um problema policêntrico. Sua resposta é a seguinte: a disposição de qualquer dos quadros tem implicações sobre a disposição de qualquer dos quadros seguintes. Quem ficar com um Renoir terá menos interesse em um Cezanne, e mais nos Bellows, por exemplo. A solução dessa partilha não poderia ser feita com base em argumentos e provas. Qualquer juiz designado a conhecer o problema "ficaria tentado a assumir um papel de mediador, ou a adotar a clássica solução: deixar o irmão mais velho (aqui o Metropolitan) dividir o acervo em partes iguais segundo seu critério, e deixar depois o irmão mais novo (a National Gallery) escolher uma das metades". 207

No segundo exemplo, Füller imagina um regime socialista no qual se houvesse resolvido que salários e preços deveriam ser estabelecidos pelos tribunais através das formas usuais de adjudicação. Parece óbvio a Füller que esse tipo de questão não pode ser resolvido dessa forma, em primeiro lugar porque os tribunais são "lentos demais para acompanhar um cenário econômico em rápida mudança." ${ }^{208}$ Mas o mais importante é que a adjudicação não poderia levar em conta as repercussões que derivariam de qualquer mudança em preços e salários. Os preços de vários produtos estão invariavelmente conectados uns com os outros e a alteração de um deles gera efeitos em cadeia na economia. Seria simplesmente impossível garantir a cada uma das incontáveis pessoas afetadas por cada decisão uma forma razoável de participação no processo, através de provas e argumentos. Mais ainda, o espectro de interessados sequer poderia ser determinado a priori, pois cada possível decisão (aumentar preços em três, quatro ou cinco

pervasively, so that some decisions would be retrospective, some prospective only, the resulting confusion might be much less bearable than the situation that now obtains.". Cf. Lon Füller, The Forms and Limits of Adjudication, p. 392

206 Idem, p. 394-404.

207 Idem, p. 394.

${ }^{208}$ Idem, p. 394. 
centavos, por exemplo) afetaria de forma diferente um conjunto igualmente distinto de agentes econômicos. ${ }^{209}$

O modelo sugerido por Füller para o problema é o de uma teia de $\operatorname{aranha}^{210}$. Qualquer ação em um ponto da teia espalha seus efeitos através dela como um todo, em um padrão complicado e em certo modo imprevisível. Outra ação no mesmo ponto não irá necessariamente dobrar a intensidade do resultado, mas pode criar um novo e mais complicado padrão de repercussões. O problema aqui é policêntrico porque remete a muitos centros de repercussão. Querer decidir judicialmente esse tipo de problema seria tão inviável quanto querer organizar um time de futebol em campo com base em um processo adjudicatório. $^{211}$

O próximo exemplo de Füller consiste em uma indústria têxtil entrando em acordo com um sindicato a respeito de sua estrutura interna de salários. Seu argumento consistiria no fato de certos salários terem ficado desproporcionais entre si ao longo do tempo, de forma que certas funções estariam pagando muito mais ou muito menos que outros trabalhos a elas equivalentes. As partes estabelecem, então, que um fundo seria criado com o equivalente a cinco centavos por hora incidentes sobre toda a folha de pagamento, de sorte a resolver o problema. Se, após a constituição desse fundo, as partes não chegassem a um acordo quanto aos ajustes a serem feitos, a questão deveria ser encaminhada a arbitramento. Novamente, essa seria uma questão com fortes elementos policêntricos, e o "árbitro" que fosse chamado a resolvê-la sentir-se-ia tentado a "experimentar" várias possíveis soluções em conversas privadas com as partes. "Irregulares e impróprias como essas conversas poderiam parecer quando observadas através dos padrões tradicionais de adjudicação, seria preciso notar que o motivo para elas poderia ser o desejo do árbitro de preservar a efetiva participação das partes na decisão, preservar, em outras palavras, o próprio núcleo da adjudicação". 212

Nessas hipóteses, diz Füller, a utilização de um painel tripartite de árbitros mostrase especialmente útil. O "árbitro imparcial" é ladeado por dois outros colegas, um

\footnotetext{
209 Idem, p. 395.

${ }^{210}$ Não deixa de ser curioso notar que esse modelo da rede passa a ser identificado, no final do século passado, com o próprio processo de produção de norma jurídica, e adjudicação de direitos e interesses. V., sobre o tema, François Ost, Jupiter, Hercules, Hermes: Tres Modelos de Juez.

211 Lon Füller, The Forms and Limits of Adjudication, p. 395.

212 Idem, p. 396.
} 
escolhido pela empresa, o outro pelo sindicato. As conversas entre eles ajudarão a esclarecer o "árbitro imparcial" acerca das conseqüências de cada possível ajuste de salários, sendo essa, então, uma forma mista de adjudicação, pois envolve tanto atividades de adjudicação propriamente ditas quanto atividades de negociação.

"Todas as formas mistas têm seus perigos, e a arbitragem tripartite não é uma exceção. Nela, o perigo mora no difícil papel desempenhado pelos árbitros indicados pelas partes. Eles não podem nem funcionar inteiramente como árbitros, nem inteiramente como partes; sua função durante as deliberações é representar um interesse, um ponto de vista. Pode ser que eles acabem querendo comunicar-se com as partes que representam para informá-las sobre as implicações de alguma medida proposta - ao passo em que, saber se elas devem fazer esse tipo de comunicação, e em qual grau, é uma das ambigüidades que assombram esse tipo de arbitragem. Se, de um lado, cada um dos árbitros escolhidos pelas partes deve representar a parte que o escolheu, de outro ele deve observar, ao mesmo tempo, algumas das restrições que são inerentes à função jurisdicional. Se ele vai e vem entre os que o representam e as reuniões do painel arbitral, reportando livremente tudo o que acontece nessas reuniões, o processo adjudicativo se quebra e é substituído por uma esquisita forma de barganha - em uma situação, lembre-se, na qual a negociação já falhou em produzir uma solução". ${ }^{213}$

Problemas policêntricos geram efeitos imprevistos e multilocalizados, mesmo quando não afetam, como de costume acontece, uma multiplicidade de pessoas (o exemplo dos quadros não envolve, por exemplo, múltiplas pessoas, mas múltiplos interesses sobre múltiplos bens). Por tal razão, essa espécie de problema não se encaixaria no modelo próprio à adjudicação, segundo Füller. Conflitos policêntricos em geral são resolvidos por métodos parlamentares que incluem uma espécie de participação em forma de "acordo" político. Por excelência, a alocação de recursos econômicos segue essa regra, já que os elementos policêntricos são de tal natureza importantes que qualquer tentativa de alocação judicial estaria fadada ao insucesso. ${ }^{214}$

\footnotetext{
213 Idem, ibidem.

214 "[P] $]$ olycentric problems can often be solved, at least after a measure, by parliamentary methods which include an element of contract in the form of the political "deal." The parties in interest - or, more realistically, the parties most obviously concerned - are called together at a legislative hearing or in a conference with legislative leaders and "an accommodation of interests" is worked out. I suggest that we need a philosophy of the "political deal" that will discern its proper uses from its abuses. I believe the concept of the polycentric problem could help in drawing the line.
} 
Para concluir seu raciocínio, Füller pergunta o que poderia acontecer quando questões policêntricas são forçadas no processo adjudicativo. Para ele, a resposta caminharia em três sentidos diferentes.

Primeiro, a solução proposta pode falhar (repercussões inesperadas podem torná-la infactível ou ineficiente). ${ }^{215}$

Segundo, as pessoas encarregadas da decisão podem perder sua condição de árbitros isentos do conflito (são obrigadas a "testar" soluções em audiências posteriores, consultar partes não presentes no processo, cogitar de fatos não alegados nem provados, etc., perdendo, assim, sua imparcialidade). ${ }^{216}$

Terceiro, ao invés de acomodar seus procedimentos para o tipo diferente de conflito que lhe é apresentado, o julgador pode acabar adaptando o conflito ao procedimento que ele sabe operar e às soluções que esse procedimento consegue gerar. ${ }^{217} 218$

If we survey the whole field of adjudication and ask ourselves where the solution of polycentric problems by adjudication has most often been attempted, the answer is: in the field of administrative law. The instinct for giving the affected citizen his "day in court" pulls powerfully toward casting exercises of governmental power in the mold of adjudication, however inappropriate that mold may turn out to be. It is interesting to observe, however, that during World War II the agencies charged with allocative tasks did not attempt to follow the forms of adjudication. The War Labor Board proceeded after the pattern of tripartite arbitration, but it was theoretically barred from raising wages to influence the flow of labor, the allocative function in this case being assigned to the War Manpower Commission, which was not an adjudicative body. The Office of Price Administration and the War Production Board, vast as their powers were, did not pretend to act adjudicatively, except in trying alleged violations.

Generally speaking, it may be said that problems in the allocation of economic resources present too strong a polycentric aspect to be suitable for adjudication. Thus, a proposal made in England after World War II that scarce newspaper print be allocated by jury verdict could hardly have been the product of serious reflection. In a somewhat different category is the proposal by James B. Conant that a "quasijudicial" procedure be used in allocating government funds among competing projects of scientific research. Obviously Dr. Conant has given serious thought to this question, and he seeks some procedure which will avoid the compromises that so often result in no project's getting enough money to make it effective. His desire to preserve the integrity of adjudication is shown by the fact that he suggests, "If there is no [competing project], some technical expert should be appointed to speak on behalf of the taxpayer against the proposed research . . . " Yet when one considers the nature of the problem of allocation, one wonders whether the "adjudication" here proposed could be that in anything but name. In allocating $\$ 100$ million for scientific research it is never a case of Project A v. Project B, but rather of Project A v. Project B v. Project C v. Project -D... bearing in mind that Project Q may be an alternative to Project B, while Project M supplements it, and that Project R may seek the same objective as Project $\mathrm{C}$ by a cheaper method, though one less certain to succeed, etc. " (Lon Füller, The Forms and Limits of Adjudication, p. 400-401).

215 Idem, p. 401.

216 Idem, ibidem.

217 Idem, ibidem.

218 Essa discussão será intensamente retomada nos itens II e III a seguir. 
Nas palavras de Füller, por razões inclusive de tradição, "o espaço próprio da adjudicação consiste em determinar, com autoridade, questões ligadas a demandas por direitos e acusações de culpa". ${ }^{219}$ Juntando essa afirmação com a anterior, ele faz a seguinte retificação na frase:

\footnotetext{
"Não é tanto que os juízes decidam apenas questões apresentadas por demandas de direitos e acusações de culpa. O ponto é que qualquer coisa que eles decidam, ou qualquer coisa que seja submetida à sua decisão, tende a converter-se em uma disputa por direitos ou em uma acusação de culpa ou prática de um ato ilícito. Essa conversão é efeito da moldura institucional dentro da qual tanto os litigantes quanto o próprio juiz funcionam. ${ }^{220}$
}

Essa “conversão" subverte, obviamente, a racionalidade dos conflitos que não se organizam com base em afirmações de direitos e acusações de culpa. Daí, então, a crítica instrumental dizer que problemas políticos (ou os conflitos policêntricos, em geral) não deveriam ser decididos pela justiça. O exemplo dos direitos sociais é em geral utilizado, hoje, para ilustrar essa afirmação.

Pode-se dizer que as três previsões de Füller concretizam-se com freqüência invulgar, o que demonstra, de certa forma, a eloqüência de seu discurso. Por outro lado, no entanto, abundam casos em que, afastando-se dos parâmetros tradicionais de ação, as cortes de justiça têm conseguido dar solução razoavelmente satisfatória a conflitos policêntricos. Alguns exemplos disso, no Brasil, são explorados por Joaquim Falcão em seu conhecido texto sobre as invasões de terra no Recife. ${ }^{221}$

A respeito das idéias até agora apresentadas, repito que meu objetivo, com este trabalho, não é o de chancelar ou rejeitar a crítica instrumental. Procuro, apenas, demonstrar como ela trabalha com uma dada concepção (liberal) de direito e justiça, e como a necessidade crescente de dar solução a conflitos distributivos tem alterado, no Brasil, as características institucionais e instrumentais que Füller aponta, por exemplo, como conaturais ao modelo adjudicajório.

Assim, creio que a chave analítica proposta por Füller (conflitos bilaterais $v$. conflitos policêntricos) possa ser melhor compreendida a partir da diferenciação entre as

\footnotetext{
219 Idem, p. 368.

220 Idem, p. 369.

${ }^{221}$ Cf. Joaquim de Arruda Falcão. Justiça social e justiça legal: conflitos de propriedade no Recife, p. 79101 .
} 
categorias da distribuição v. comutação e do interesse v. direito subjetivo. Por essa razão, procuro explorar essas dicotomias, respectivamente, nos itens II e III, adiante. Antes disso, contudo, penso que valha a pena referir dois outros exemplos marcantes da crítica instrumental. O primeiro vem da ciência política americana. Trata-se do trabalho de Donald L. Horowitz, trazido a público em $1977^{222}$. O segundo é nacional e deriva da literatura jurídica. Consiste em um texto publicado em 2002 por Botelho de Mesquita. ${ }^{223}$

Em The Courts and Social Policy, Horowitz, que também é cientista político, tenta enfrentar o problema da capacidade institucional das cortes de justiça para a solução de conflitos envolvendo políticas públicas. Horowitz procura fazê-lo a partir da análise de quatro estudos de caso.

Segundo Horowitz, as cortes americanas, que são seu objeto de estudo, têm estado mais propensas que quaisquer outras a engajar-se em novos desafios, aceitar novas tarefas, redesenhar seu papel. Também por isso, têm sido procuradas mais e mais, e têm assumido a responsabilidade pela construção de políticas públicas em uma intensidade incomparável entre seus pares internacionais. ${ }^{224}$

Para Horowitz, aquilo que os juízes vinham fazendo até idos de 1977 poderia ser considerado novo em um sentido bastante especial. Eles redesenhavam os padrões de manipulação de alimentos, iluminação, acomodação e tratamento médico em presídios, determinavam as condições de trabalho em escolas, ordenavam ao Estado que provesse educação bilíngüe à população hispânica, por exemplo. E boa parte dessas atividades derivavam de convites à ação feitos pelo próprio legislativo, através de standards mais e mais abertos de controle judicial previstos pelo parlamento, ou de leis tão vagas, tão amplas e indeterminadas que acabavam por não resolver os problemas sociais de que deveriam cuidar, transferindo sua solução ao judiciário. ${ }^{225} \mathrm{O}$ contencioso judicial deixava de ser, assim, uma instância de resposta a queixas específicas, para tornar-se mais e mais uma instância de solução de problemas complexos. ${ }^{226}$

\footnotetext{
222 V. Donald L. Horowitz, The Courts and Social Policy.

${ }^{223}$ V., José Ignácio Botelho de Mesquita, As novas tendências do direito processual: uma contribuição para seu reexame.

224 V. Donald L. Horowitz, The Courts and Social Policy, p. 3.

225 Idem, p. 5.

${ }^{226}$ Idem, p. 7.
} 
No contexto dessas transformações é que Horowitz explica como nasce, fundamentalmente, aquela que estou chamando de crítica instrumental. Segundo ele, o escopo próprio do Poder Judicial no sistema americano de governo vinha sendo, até então, o de declarar atos do executivo ou do parlamento inconstitucionais. Por isso, o debate sobre o papel do judiciário era um debate de legitimidade. ${ }^{227}$ À medida em que esse debate esmaece (também pela percepção de déficits democráticos importantes nos outros poderes), e à medida em que o papel das cortes se transforma materialmente, o debate passa para o problema da capacidade. Agora, já não se trata tanto de saber o que as cortes deveriam fazer, mas sim de descobrir aquilo que elas podem fazer "de forma competente". 228

Um desses problemas de "competência” relaciona-se, como já mencionei antes, ao problema da inércia. "O fato de os juízes terem que agir apenas quando provocados significa que eles acharão difícil divisar", no campo das políticas públicas, "um programa coerente de ação". Nesse contexto, o caráter reativo da jurisdição implica decisões ad hoc, dadas "um caso por vez"229, as quais são, como tentarei demonstrar abaixo com alguns exemplos de irracionalidade distributiva, geralmente erráticas e regressivas.

Além disso, Horowitz destaca um problema importante, que é o da convivência, mais que o da substituição, de papéis institucionais. Segundo ele, "as instituições estão em geral um passo atrás das tarefas que elas têm que desempenhar" e "isso é provavelmente mais verdadeiro se as novas tarefas tiverem sido adicionadas às antigas, sem eliminá-las, de modo que o problema não é simplesmente de transformação mas sim de desempenhar ambas as tarefas". 230

As políticas públicas exigem, muitas vezes, especialização técnica para serem bem desenhadas. Os juízes são, no entanto, generalistas. Ponderadamente, Horowitz não vê nisso um problema em si, mas identifica aí um campo potencial de conflito. "Em uma sociedade complexa, altamente diferenciada, o papel do generalista não deve ser afastado", diz ele. "O intérprete, a pessoa que se coloca nas sinapses e faz as conexões entre subsistemas e subculturas, é uma parte vital de qualquer processo de construção de

\footnotetext{
227 Idem, p. 17.

228 Idem, p. 18.

229 Idem, p. 23.

${ }^{230}$ Idem, ibidem.
} 
políticas públicas. Sem prejuízo disso, o peso relativo dado à opinião do especialista ou do generalista e o tipo de input trazido por cada qual podem moldar de forma distinta a decisão resultante. Uma conseqüência do domínio do generalista sobre o processo decisório... é que, nos interstícios onde o conhecimento específico falta, aquele tende a preencher as lacunas com seus próprios “axiomas normativos generalizados”. Não parece claro que os axiomas normativos generalizados dos juristas, que até agora preencheram os vazios das decisões judiciais, estejam bem adaptados ao processo de formulação de políticas em todas as áreas às quais eles tem sido aplicados."231

Com os exemplos que irei referir no item II, abaixo, tentarei mostrar que uma das principais razões que pode conduzir a resultados distributivos desastrosos é a incapacidade de dominar a informação necessária à avaliação dos impactos precisos de uma dada decisão dessa natureza. Nesse contexto, o generalismo é apontado novamente como um problema por Horowitz, pois, ostentando essa condição, os juízes não apenas se ressentem das informações necessárias à ação social eficiente, como também parecem não possuir a experiência e habilidades necessárias para interpretar a informação que possam, por acaso, receber. ${ }^{232}$ Segundo Horowitz, por razões de tradição ou não, fato é que "o processo judicial conspira em uma dúzia de modos pequenos e grandes para manter o juiz ignorante acerca do contexto social." ${ }^{, 233}$ Ele força o juiz a agir por partes, focado em problemas particulares e não no todo. Força-o a estreitar suas possibilidades de escolha através da procura por direitos e deveres. Força-o a escolher suas soluções dentro do leque restrito da permissão, proibição ou imposição, mas não o deixa, por exemplo, permitir sob condição (admitir uma conduta em sua sentença mas impor sobre ela um encargo qualquer). ${ }^{234}$

Se é certo que as cortes são, em princípio, dependentes dos problemas que lhe são apresentados, na extensão em que são apresentados, por aqueles que resolvem apresentálos, também é certo que não existe, nesse ponto, qualquer garantia de que os "intérpretes" ou "porta-vozes" do conjunto de interesses efetivamente trazidos a juízo sejam, em sua condição, exemplos típicos daqueles que ostentam tais interesses. Aliás, em geral ocorre o inverso, pois a boa estratégia de advocacia faz com que as partes tentem levar a juízo sobretudo os exemplos mais extremos de abuso, violação da lei, discriminação ou fraude.

\footnotetext{
231 Idem, p. 25.

${ }^{232}$ Idem, p. 31.

${ }^{233}$ Idem, ibidem.

234 Idem, p. 35.
} 
Pelo exemplo extremo tentam sensibilizar as cortes, mas apresentam, para esse propósito, uma parcela da realidade que está longe de ser típica ou exemplar. ${ }^{235}$

Derradeiramente, o processo judicial não deixa margens à revisão das políticas que são por ele determinadas ${ }^{236}$. Isso ocorre, acrescento eu, também em virtude do regime próprio à coisa julgada, sem prejuízo das razões estruturais já mencionadas acima. Mas, além disso, fato é que as cortes não têm como avaliar de forma completa as conseqüências erráticas de suas próprias políticas. Dependem, para isso, da ação subseqüente das partes, e essa ação dificilmente produzirá o conhecimento quanto a tais desvios se eles forem de tal modo que acabem afetando a terceiros.

Com essas premissas em mente, e após ter feito a análise detida de todos os seus casos-exemplo, Horowitz conclui: "no geral, todos esses casos sugerem que o processo judicial não se presta adequadamente ao balanceamento de alternativas e ao cálculo de custos.” ${ }^{237}$ Sendo essas qualidades inerentes à formulação de políticas públicas, isso significa que as cortes de justiça ressentem-se de instrumentos adequados à sua formulação.

Horowitz faz uma advertência final, atinente à possibilidade de transformação desses instrumentos de sorte a aparelhar as cortes para a tarefa de engenharia social que elas vêm desempenhando. São as palavras que encerram o trabalho: "o perigo é que as cortes, melhorando sua capacidade de ação ao aprender com o trabalho das outras instituições, acabem terminando bem parecidas com estas.",238

Essa advertência serve de mote para a abordagem do trabalho seguinte, de José Ignacio Botelho de Mesquita, uma vez que esse trabalho é focado, sobretudo, na visão do autor quanto aos perigos envolvidos nas transformações recentes por que têm passado as cortes de justiça no Brasil.

De fato, Botelho de Mesquita procura apreender em seu texto certas mutações pelas quais estaria passando o direito processual civil em tempos recentes. Essa mutações poderiam dividir-se em "alterações necessárias a que o processo se aperfeiçoe enquanto

\footnotetext{
235 Idem, p. 41.

236 Idem, p. 51.

237 Idem, p. 257.

${ }^{238}$ Idem, p. 298.
} 
instrumento para a realização de um fim determinado, sem que este fim em si mesmo seja alterado" (mutações técnicas), e alterações "que se tornam necessárias em razão de se haver alterado o fim que por meio do processo se visa a atingir" (mutações políticas) ${ }^{239}$. Exemplo das primeiras seriam as alterações introduzidas pelo Código de Processo Civil de 1973. Já as segundas ocorreriam quando "se deixa de considerar o processo como um instrumento a serviço da realização do direito e se passa a tê-lo como um instrumento para se coibir a violência, promover a pacificação social e divulgar no seio do povo o conhecimento do direito. O processo voltado para esses fins deve se ocupar, antes, com a conciliação entre os litigantes do que com a submissão dos fatos ao império da lei"240.

Botelho de Mesquita lança mão das idéias de jurisdição contenciosa e voluntária para trabalhar em profundidade a distinção proposta acima. Na primeira, diz o autor, a obrigação do juiz é decidir de acordo com a lei, só aplicando a eqüidade nos casos expressamente previstos naquela. Já na jurisdição voluntária não operaria essa regra, valendo a prolação de decisões com base em critérios de conveniência e oportunidade. ${ }^{241}$

A jurisdição voluntária seria atividade secundária do Poder Judiciário, ${ }^{242}$ consistindo em "limitação excepcional da autonomia e da liberdade próprias da vida privada, justificada pela possibilidade de ocorrer interferência ou perigo de conflito entre interesses privados e interesses públicos. ${ }^{, 243}$ Cuidaria, na dicção de Frederico Marques, da administração pública de interesses privados, ainda que não se limitando apenas a isso. ${ }^{244}$

O autor faz uma interessante distinção entre a proteção de direitos e interesses em seu raciocínio. Em sua aguda visão, que procurarei retomar adiante, a "violação ou ameaça de violação de algum direito subjetivo" ensejaria atividades de jurisdição contenciosa, ao passo em que a "defesa de interesses objetivos, a fim de prevenir conflitos entre estes e os interesses subjetivos" seria o campo próprio da jurisdição voluntária.

${ }^{239}$ Cf. José Ignácio Botelho de Mesquita, As novas tendências do direito processual: uma contribuição para seu reexame, p. 47.

${ }^{240}$ Idem, ibidem.

241 Idem, p. 48.

242 Idem, p. 49.

243 Idem, p. 48.

${ }^{244}$ Idem, ibidem (o grifo é meu). Mais adiante (p. 51) o autor esclarece de forma direta que a distinção entre os modos de ser da jurisdição voluntária e da jurisdição contenciosa decorre, mesmo, da oposição que há entre "os interesses políticos, econômico-financeiros ou sociais e, de outro lado, os interesses que configuram os direitos subjetivos". 
Conforme o autor, na jurisdição voluntária não há lide nem partes, não há contraditório no sentido constitucional, ainda que seja observado o princípio dialético, o processo tem feição inquisitória, é relevado o critério de legalidade estrita, impera a informalidade, a celeridade a simplicidade de procedimento e a sentença é plenamente modificável, não incidindo sobre ela a qualidade preclusiva da coisa julgada. ${ }^{245} \mathrm{~A}$ tese de Botelho de Mesquita, que nesse ponto enseja uma perspicaz observação do que parece mesmo vir ocorrendo na realidade, é que a atividade jurisdicional tem mais e mais se aproximado desse modelo, transformando-se, assim, de jurisdição contenciosa em jurisdição voluntária. Na crítica do autor, isso representaria violência ao princípio do Estado de Direito construído pelo início do constitucionalismo moderno no final do século XVIII, marcando uma crescente tendência dos sistemas políticos em direção a um inaceitável autoritarismo. $\mathrm{Na}$ transição para um modelo de jurisdição voluntária, prevaleceriam os interesses do Estado sobre aqueles dos cidadãos, quebrando-se, ainda, a garantia de separação de poderes e preservação de liberdades do Estado Liberal. ${ }^{246}$ Botelho de Mesquita procura traçar paralelos, nesse sentido, entre o modelo emergente e os direitos soviético, nazista e fascista. ${ }^{247}$

Botelho de Mesquita vê ser recebida no Brasil "a idéia de um processo propositadamente ideológico, ou ideologizado". ${ }^{248}$ Mais uma vez, tenta traçar as origens dessa recepção à história autoritária do pós-1964. Segundo o autor, a experiência autoritária teria deixado o Judiciário "depauperado, moralmente desgastado, arruinado economicamente". Disposta a "aprumar-se", a instituição teria reagido, no contexto de democratização, "criando uma nova figura de juiz, ou mesmo um novo juiz, o que acabaria por reclamar a criação de um novo processo". 249 Em um tal contexto, o ideal de “efetividade do processo" passa a ser usado como um "meio de assegurar o governo dos juízes". 250

\footnotetext{
245 Idem, p. 51.

246 Idem, passim.

247 "Na verdade o ideal de um processo do tipo que serve à jurisdição voluntária, caracterizado fortemente pela independência do juiz diante da lei, vinculado apenas aos fins sociais e à política do Estado, sempre foi a marca dos regimes de opressão" (Idem, p. 55).

248 Idem, p. 58.

249 Idem, ibidem.

250 Idem, p. 59.
} 
Segundo o diagnóstico do autor, "essa mutação política introduzida no Direito Processual conduz à paulatina absorção da jurisdição contenciosa pela jurisdição voluntária; acarreta desprestígio para o Legislativo e reforça as desconfianças do Poder Executivo, levando os dois poderes a, em defesa própria, se unirem contra o Judiciário. As demonstrações disto são várias. Estão excluídas dos Juizados Especiais, onde não se julga segundo a lei, as causas de interesse da Fazenda Pública (Lei $n^{\circ}$ 9.099/95, art. $3^{\circ}, \S 2^{\circ}$ ). Limitou-se a concessão de medidas cautelares contra o Poder Público, inclusive na ação civil pública (Lei $n^{\circ}$ 8.437/92). Restringiu-se drasticamente a concessão e a eficácia da tutela antecipada contra o Poder Público e se impuseram limites territoriais à coisa julgada nas ações civis públicas (Lei $n^{\circ}$ 9.494/97). E, mais recentemente, por medidas provisórias suspensas pelo Supremo Tribunal Federal, pretende o Executivo ampliar o prazo e os casos de cabimento da ação rescisória de interesse do Poder Público (MP $\mathrm{n}^{\circ}$ 1.798, de 13.1.1999). Essas restrições todas têm um ponto em comum. Limitam a eficácia dos juízos sumários e restringem a discricionariedade dos juízes; exatamente o carro-chefe das reformas processuais posteriores à Constituição de 1988. Reforçam o princípio da legalidade e restauram as garantias do devido processo legal, embora apenas a favor do Poder Público". 251

A crítica liberal (no sentido político) de Botelho de Mesquita transforma-se em crítica instrumental, à luz dessas considerações, nos seguintes termos: "a redução da litigiosidade contida, a pacificação social e a promoção do bem comum, por exemplo, não se conseguem alcançar com reformas legislativas e menos ainda as processuais. Constituem objeto de outro setor da atividade do Estado - a assistência social - que não é da competência dos juízes. A única contribuição efetiva que os juízes têm para oferecer à sociedade está em proporcionar a certeza de que os litígios serão resolvidos segundo a lei e no tempo mais curto possível; o que só se consegue com estudo e muito trabalho em quantidade compatível com o número dos feitos.",252

Füller diria, como vimos, que tudo o que é submetido a uma decisão judicial acaba por "converter-se em uma disputa por direitos ou em uma acusação de culpa ou prática de um ato ilícito". Aí residiriam os perigos da submissão de conflitos policêntricos à máquina

\footnotetext{
${ }^{251}$ Idem, ibidem. Sobre o tema da discricionariedade judicial, no contexto da discussão proposta por Botelho de Mesquita, v. José Roberto dos Santos Bedaque, Discricionariedade judicial, p.187-95.

252 José Ignácio Botelho de Mesquita, ob. cit., p. 68.
} 
judiciária. Füller diz que “[e]ssa conversão é efeito da moldura institucional dentro da qual tanto os litigantes quanto o próprio juiz funcionam". ${ }^{253}$

A visão de Botelho de Mesquita parece ser diametralmente oposta a essa. Na linha de seu argumento, talvez seja possível dizer que a recente evolução da justiça no Brasil estaria paulatinamente transformando "disputas sobre direitos e acusações de culpa" em questões policêntricas, em problemas que envolvem o interesse do Estado e não dos particulares. Daí a transição da jurisdição contenciosa para a jurisdição voluntária.

Independentemente dos juízos de valor e conseqüência presentes no texto de Botelho de Mesquita (com os quais não concordo, pelas razões que explicarei adiante), seu diagnóstico quanto às transformações ocorridas no Brasil é bastante preciso. Ele parece ver claramente o caminhar em direção à tutela de interesses sobrepujar a tutela de direitos subjetivos. Parece ver construir-se uma justiça que relativiza a força preclusiva da coisa julgada, transforma o contraditório judicial em um jogo algo distinto daquilo a que remeteria a noção clássica de duas partes em confronto, coloca o juiz em um papel central, criador de novos focos de juridicidade, privilegia a mediação.

Em comum entre os dois textos há, sobretudo, uma certa visão daquilo que deveria ser a moldura institucional adequada à máquina judiciária. ${ }^{254}$ Acontece, no entanto, como o próprio texto de Botelho de Mesquita ressalta, que essa moldura institucional não é necessária.

Ao invés disso, ela remete claramente a uma certa formulação acerca do papel do direito na sociedade, coincidente com o modelo de direito implementado pelo projeto moderno-liberal. Tento mostrar adiante como essa formulação liberal condiciona fundamentalmente a crítica instrumental, fazendo referência, simultaneamente, aos problemas da distribuição e da comutação no direito (e nas decisões judiciais).

${ }^{253}$ Lon Füller, The Forms and Limits of Adjudication, p. 369.

254 Nesse ponto os textos partilham de uma linha comum, que acaba por assimilar a crítica instrumental à crítica de legitmidade, através da afirmação de certos valores liberais. A crítica de Horowitz é, nesse sentido, bastante diferente dessas, procurando manter-se, sempre, no plano instrumental. 


\section{II}

\section{JUSTIÇA DISTRIBUTIVA E JUSTIÇA CORRETIVA: UMA PERSPECTIVA DE ANÁLISE}

Em um texto instigante publicado em 1994 na Revista USP, José Reinaldo Lima Lopes parece de fato retomar a discussão proposta por Füller quanto à capacidade das cortes de justiça de fazer frente a conflitos policêntricos. ${ }^{255}$ Lima Lopes lança mão, contudo, de uma outra chave analítica para desenvolver seu argumento. Ao invés de referir-se aos efeitos policêntricos intrínsecos à solução de certos tipos de conflito, como faz Füller, trabalha sobre as conseqüencias distributivas de certas decisões judiciais.

Lima Lopes está pensando sobretudo no processo de judicialização da vida política brasileira ocorrido nas décadas de 1980 e 1990. Ele vê, como produto desse processo, três novas espécies de conflitos desaguarem no Judiciário.

A primeira envolve "questões de limitação dos poderes". São problemas relacionados ao "enfrentamento de atribuições" entre os poderes tradicionais do Estado, derivados da necessidade de reinterpretar os papéis institucionais desses órgãos frente à nova carta política, ou relacionados, genericamente, à "necessidade de espetáculo público numa sociedade de mídia". ${ }^{256}$

Em segundo lugar estariam os conflitos coletivos envolvendo políticas públicas. Nessa espécie de litígio, segundo o autor, a ação judiciária não estaria seguindo um modelo adjudicatório, e o órgão judiciário estaria funcionando mais como um canal de visibilidade para as discussões políticas, como um instrumento usado para criar impasses que levem a novos arranjos e negociações institucionais.

Finalmente, Lima Lopes vê eclodirem ao amparo do processo de judicialização da vida pública brasileira conflitos coletivos relativos a demandas individuais, repetidas na sociedade de massas. ${ }^{257}$

\footnotetext{
${ }^{255}$ Cf. José Reinaldo Lima Lopes, Justiça e Poder Judiciário ou a virtude confronta a instituição. É de se notar, contudo, que o autor não se refere em nenhum momento ao trabalho de Füller e conduz seu discurso por um caminho completamente diferente daquele percorrido pelo professor americano. A semelhança entre os raciocínios decorre, apenas, mas fundamentalmente, de sua estrutura.

${ }^{256}$ Idem, p. 24.

${ }^{257}$ Idem, ibidem.
} 
Para o autor, esses novos conflitos (mais que coletivos, plurilaterais) denotariam a crise do modelo liberal de justiça comutativa, no qual a função judicial equivaleria a um mero serviço público de resolução de conflitos individuais, mediante a aplicação de regras estáticas e claras, de incidência retrospectiva, destinadas a regular indivíduos informados, livres, iguais e capazes de autodeterminarem-se. A eclosão de um novo tipo de contencioso judicial estaria então relacionada ao "problema tradicional da justiça distributiva", 258 correspondente, por sua vez, "à alocação ou apropriação individual de recursos comuns". 259

Seguindo com seu argumento, Lima Lopes procura demonstrar como a tradição liberal acaba por separar as noções de direito e política, assimilando a idéia de justiça comutativa aos domínios do direito, e a de justiça distributiva à política. Essa distinção estaria, modernamente, em crise. No contexto dessa crise seria possível, então, compreender as dificuldades que o órgão judiciário nacional estaria enfrentando para dar conta dos novos tipos de conflito a ele encaminhados.

Os conceitos de justiça comutativa e distributiva, utilizados pelo autor, fazem referência à teoria da justiça proposta no Livro V da Ética a Nicômacos, de Aristóteles. ${ }^{260}$ Ali, afirmava Aristóteles haver "mais de uma espécie de justiça", sendo que "[u]ma das espécies de justiça em sentido estrito... é a que se manifesta na distribuição de funções elevadas de governo, ou de dinheiro, ou das coisas que devem ser divididas entre os cidadãos que compartilham dos benefícios outorgados pela constituição da cidade”.

Em oposição a essa justiça distributiva estaria a justiça corretiva, "que desempenha uma função corretiva nas relações entre as pessoas". Essa justiça corretiva, comutativa ou retributiva seria passível ainda de subdivisão, ficando de um lado a justiça das "relações voluntárias", como "a venda, a compra, o empréstimo a juros, o penhor, o empréstimo sem juros, o depósito e a locação", e de outro a justiça das "relações involuntárias", como aquelas decorrentes de furto, adultério, envenenamento, lenocínio, desvio de escravos, assassínio traiçoeiro, mutilação, roubo, injúria, ultraje. ${ }^{261}$

\footnotetext{
${ }^{258}$ Idem, ibidem.

259 Idem, p. 25.

260 Aristóteles, Ética a Nicômacos, p. 91 a 111.

261 Idem, p. 95.
} 
Em Aristóteles, a noção de justo remete a conceitos diferentes conforme se esteja tratando da justiça distributiva ou da justiça corretiva. Na primeira, “o justo... é uma das espécies do gênero 'proporcional'. Na segunda, ou seja, na “justiça das relações privadas” o justo remete ao "igual".

Se quisermos, contudo, manter a noção de proporção em um ou outro casos, a justiça distributiva remeteria à idéia da "proporção geométrica" (à medida, portanto), ao passo em que a justiça corretiva remeteria à "proporção aritmética" (donde, modernamente, o nome de justiça comutativa, ou seja, das comutações). ${ }^{262}$

É verdade que esses conceitos poderiam modernamente remeter, tanto quanto os de bilateralidade e policentrismo, a tipos ideais ${ }^{263}$. Não obstante, a distinção entre as esferas da justiça distributiva e da justiça retributiva não é propriamente clara no texto original, de modo que aquela parece poder, em muitos casos, aplicar-se também às "relações privadas". Assim, por exemplo, seria possível também aferir a justiça proporcional das trocas, segundo a qual "o construtor deve obter do sapateiro o produto do trabalho deste, e deve por sua vez oferecer-lhe em retribuição o produto de seu próprio trabalho. Se houver uma igualdade proporcional dos bens, e se ocorrer uma ação recíproca, verificar-se-á o resultado [justo] que mencionamos. Se não ocorrerem estas duas circunstâncias, a permuta não será igual, e o relacionamento não continuará”. ${ }^{264}$

Voltando ao texto de Lima Lopes, para entender a distinção entre justiça comutativa e distributiva seria preciso entender que a sociedade não é composta, simplesmente, por uma soma de indivíduos, ou das necessidades e relações desses indivíduos. Seria preciso compreender a noção de bem comum. A justiça distributiva teria como objeto o bem comum, sobretudo numa perspectiva deontológico-procedimental. ${ }^{265}$ Seria coincidente com a regra de distribuição igual (proporcional) de coisas comuns (não produzidas por ninguém), de coisas produzidas em comum, de autoridade, poder e

\footnotetext{
${ }^{262}$ Idem, p. 97

${ }^{263}$ Cf. Max Weber, Metodologia das Ciências Sociais. "Obtém-se um tipo ideal mediante a acentuação unilateral de um ou de vários pontos de vista e mediante o encadeamento de grande quantidade de fenômenos isoladamente dados, difusos e discretos, que se podem dar em maior ou menor número ou mesmo faltar por completo, e que se ordenam segundo os pontos de vista unilateralmente acentuados, a fim de se formar um quadro homogêneo de pensamento. É impossível encontrar empiricamente na realidade este quadro, na sua pureza conceitual, pois trata-se de uma utopia". Idem, p. 137-8.

264 Aristóteles, Ética a Nicômacos, p. 99.

265 José Reinaldo Lima Lopes, Justiça e Poder Judiciário.., p. 27.
} 
liberdade, com as respectivas responsabilidades e recompensas, e de incentivos a talentos socialmente relevantes e desejados. ${ }^{266}$

Os temas que têm chegado ao judiciário são, segundo Lima Lopes, predominantemente de justiça distributiva. Quem é a parte adversa, nesses casos? É a própria organização social. E o problema é que o conflito chega ao judiciário reduzido ao signo de um conflito de interesses, de atores individualizados. Essa conclusão remete, claramente, à advertência de Füller, já várias vezes referida: também aqui, a submissão dos conflitos distributivos ao poder judiciário acaba provocando a sua "conversão" em uma “disputa por direitos”, ou sua redução a acusações de culpa ou prática de ilícitos. Se lembrarmos daquela primeira definição de Aristóteles, concernente às relações voluntárias (a venda, a compra, o empréstimo, o penhor, a locação...) e involuntárias (furto, adultério, envenenamento, assassínio...), sobre as quais incide a justiça retributiva, teremos que essa conversão transmuta o conflito distributivo em conflito retributivo.

Os problemas daí decorrentes serão discutidos um pouco mais adiante. Por ora, procuro apontar os problemas atuais que Lima Lopes identifica na ação do Poder Judiciário, como produto do estado de coisas por ele descrito.

Por um lado, destacam-se os problemas incidentes também sobre a justiça comutativa: ampliação da capacidade de atendimento (pessoas, recursos materiais, reorganização do processo, da burocracia, da carreira judicial, das carreiras de apoio, da polícia, do ministério público, etc.), coletivização dos conflitos típicos de justiça comutativa (consumo, por exemplo) e combate à impunidade, sobretudo. ${ }^{267}$

Os problemas práticos da justiça distributiva são, segundo o autor, mais graves, ligando-se ao plano da legitimidade política. O Judiciário opera no caso concreto e suas decisões de justiça distributiva atuam sob a racionalidade coletiva da apropriação

\footnotetext{
${ }^{266}$ Idem, ibidem. Note-se que a possibilidade de se distribuírem liberdades demonstra que os problemas da justiça distributiva nem sempre referem problemas de escassez de recursos materiais, como se poderia, em princípio, imaginar. Ainda que boa parte das dificuldades relacionadas à aplicação judicial de regras de distribuição esteja, no Estado Social, ligada a esse tipo de bens (a efetivação dos direitos sociais é exemplo claro disso), podem haver conflitos distributivos importantes tendo por objeto pura divergência moral. As discussões sobre o direito ao aborto remetem a isso. Mas também as liberdades parecem poder consistir, elas mesmas, em recursos escassos, sobretudo quando chocam-se entre si, ou com outras liberdades. O direito de agir livremente nos mercados, cada vez mais restrito no contexto do Estado Social, é um exemplo que me vem imediatamente.

${ }^{267}$ Idem, p. 28-9.
} 
individual de bens comuns, mas não o fazem com vistas ao coletivo, e sim ao individual; isso cria uma sensação de injustiça da decisão concreta, que passa a ser vista como privilégio. O caso típico, aqui, é o da efetivação dos direitos sociais. Na justiça distributiva aplicada ao caso individual, fica difícil ver com clareza a contraparte coletiva do benefício ou do sacrifício imposto ao indivíduo participante do processo ${ }^{268}$.

Tentarei retomar esse tema adiante, com alguns exemplos. De qualquer forma, a análise da ação judiciária sob o prisma da dicotomia distribuição v. comutação iluminaria, segundo Lima Lopes, alguns possíveis limites do órgão judiciário para a solução de conflitos distributivos. Não por acaso, são substancialmente os mesmos geralmente apontados pela crítica instrumental.

Assim, (a) os limites subjetivos da coisa julgada (ou a eficácia intra-partes da sentença) impediriam a aplicação das decisões a todo o universo social, criando distorções e privilégios, (b) a estrutura de decisão com base na referência à lei retiraria legitimação política para o órgão decidir politicamente (digo eu: de forma consequencialista), (c) o contraditório bilateral não se adequaria à natureza plurilateral dos conflitos distributivos, (d) a inércia institucional do órgão atuaria em favor apenas daqueles que sabem como invocar a proteção do judiciário, gerando ainda uma visão sempre parcial dos conflitos, (e) as idéias de precedente, tradição e cultura jurídica trariam em si um elemento estático incompatível com a justiça dinâmica, distributiva, (f) o aparelhamento insuficiente do órgão judiciário dificultaria o acesso a informações importantes para a tomada de decisões com efeitos coletivos, o que acabaria por fazer do judiciário mais uma instância de mediação, de adiamento do conflito enquanto se negocia uma solução definitiva fora de juízo, que propriamente uma instância de decisão. ${ }^{269}$

A falta de acesso à informação especializada é, como tento desenvolver abaixo, um problema grave e efetivo. Mas a função mediadora do judiciário não parece sê-lo, mesmo no plano coletivo dos conflitos distributivos. Lima Lopes mesmo o reconhece. ${ }^{270} \mathrm{Se}$

\footnotetext{
${ }^{268}$ Idem, p. 29-31.

${ }^{269}$ Idem, p. 31-33

${ }^{270}$ Idem, p. 33.
} 
pensarmos no conhecido modelo de François Ost, estaria agindo, aqui, o juiz Hermes, modelo de magistrado no Estado Regulador. ${ }^{271}$

Por sinal, esses três modelos de juiz propostos por Ost, com base, é verdade, na figura do Juiz Hércules de Dworkin, podem bem servir para dar conta de como o projeto moderno forjou seu direito e suas instituições. $\mathrm{Na}$ verdade, esse projeto passou pelo afastamento do direito em relação aos conflitos distributivos. Forjadas com vistas à aplicação de um tipo de direito que se resumiria às trocas e às punições, as instituições judiciárias liberais desabilitaram-se para o enfrentamento das distribuições. Essa é, creio, a verdadeira origem do desarranjo estrutural identificado pela crítica instrumental.

Essa mesma constatação demonstra, contudo, que esse desarranjo não é necessário, uma vez que a "verdadeira adjudicação",272 não passa, aparentemente, de uma das possivveis interpretações do mecanismo adjudicatório, própria à tradição liberal. Nesse passo, a análise contextualizada parece revelar um elemento normativo adicional que se esconde por trás da crítica instrumental, ou ao menos de parte dela (os textos de Füller e Botelho de Mesquita são exemplos claros do que quero dizer). Nessa dimensão normativa adicional, já não se trata tanto de afirmar que o judiciário não deve avançar em questões distributivas por não ser institucionalmente habilitado a tanto, mas sim de dizer que o modelo que o desabilita é melhor, superior funcionalmente a outros modelos que lhe pudessem ser concorrentes.

O modelo de justiça fundado nas trocas e punições é tributário da tradição racionalista das codificações européias e do processo adversarial saxônico ${ }^{273}$. Em comum nesses projetos está, sobretudo, o foco no individualismo, na capacidade humana de apropriação individual dos bens, de possuir, dispor, manipular.

É na fundação do Estado Liberal que o direito, antes compreendido como ordenação para o bem comum, como expressão do justo (do justo como o proporcional), passa a identificar-se com o próprio, com a faculdade de exercer domínio sobre certas titulações e, portanto, de dispor delas (comutá-las). Esse movimento é detalhadamente

\footnotetext{
${ }^{271}$ Cf. François Ost, Jupiter, Hercules y Hermes: Tres Modelos de Juez, passim.

272 V. Lon Füller, The Forms and Limits of Adjudication.

${ }^{273}$ V., sobre a noção anglo-saxônica de processo adversarial, Michele Taruffo, Il Processo Civile 'Adversary' Nell'Esperienza Americana.
} 
descrito por José Reinaldo Lima Lopes em outro trabalho, dedicado à transmutação dos campos semânticos das palavras lei e direito no forjar da tradição liberal. ${ }^{274}$

Segundo o autor, "ao longo da modernidade mudam os termos de comensurabilidade, o que define as igualdades e, fundamentalmente, deixa-se de inquirir das formas de igualdade proporcional adequadas às regras de distribuição em situações de indivisibilidade. Dessa maneira, o sentido final de um sistema jurídico, a justiça como igualdade, fugiu ao âmbito dos juristas pouco a pouco, ou pelo menos fugiu naquilo que é a justiça distributiva, a qual passou a pertencer ao universo e à disciplina da política."275

Lima Lopes mostra como a idéia de lei (lex) deixa paulatinamente de referir a noção de regra, de medida, de autoridade e razão ${ }^{276}$, para significar cada vez mais intensamente ordem e comando, a partir do jusnaturalismo moderno. ${ }^{277}$ Semelhantemente, a noção de direito (ius) se transporta de um sentido objetivo (o correto, o lícito positivo e objetivo, a que se opõe a iniuria) para um sentido subjetivo, de faculdade, capacidade de exercer domínio sobre alguma coisa, ${ }^{278}$ ou mesmo de liberdade ${ }^{279}$. Assim, se o direito medieval ainda era uma espécie de ciência política ou filosofia política aplicada, ${ }^{280} \mathrm{o}$ direito do século XIX passa a ser ordem positiva, "determinação do Estado de que algo deva ser direito", na dicção de Windscheid, ${ }^{281}$ "estudo das regras mínimas que pudessem garantir a estabilidade de pactos e contratos.

No projeto liberal separam-se, portanto, as esferas do direito e da política. "Questões de distribuição passam a ser matéria do poder discricionário" e "interesses não se equiparam aos direitos". ${ }^{283}$ Apenas destes últimos passa a cuidar a ordem jurídica, que não comporta mais, assim, qualquer discussão substancial de justiça (justiça como proporcionalidade). Sobretudo quando o projeto liberal é interpretado pelo positivismo

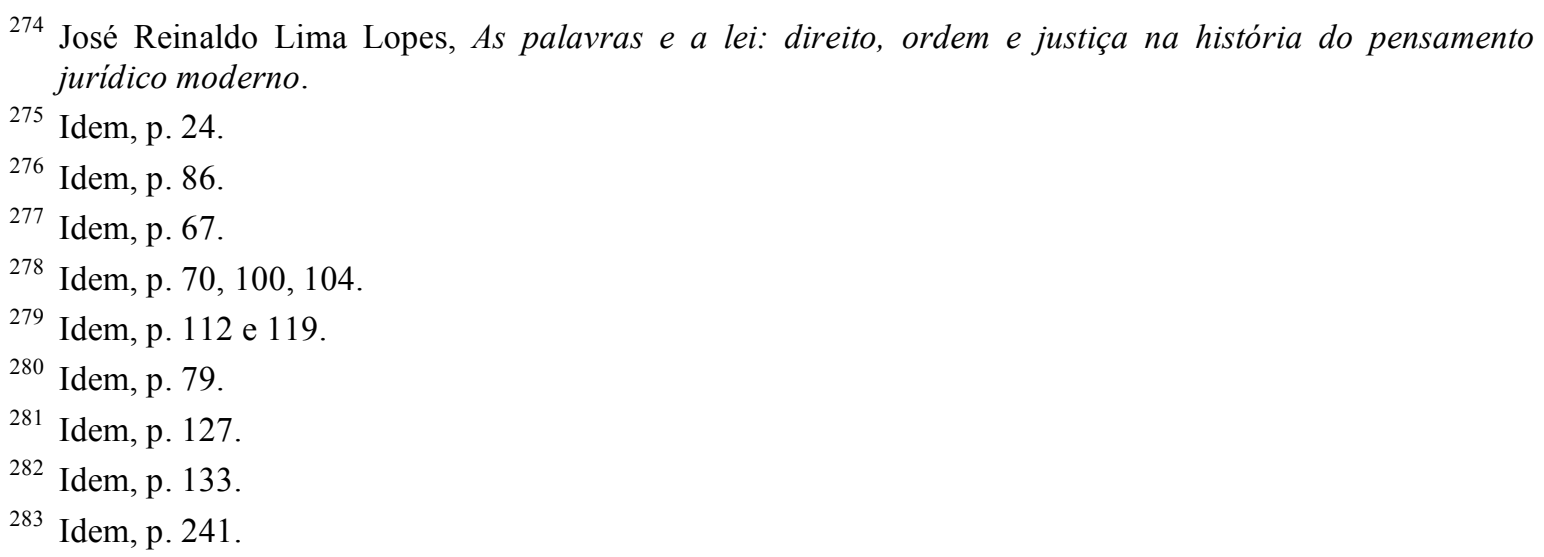


jurídico do final do século XIX e início do século XX, “a discussão da justiça, como elemento racional fundante da ordem jurídica ou das leis em particular, perdeu progressivamente importância". ${ }^{284}$

Parece-me que a crítica instrumental deva ser entendida, pois, nesse contexto. Quando pensada à luz da concepção liberal de direito e justiça, ela deixa de se endereçar a um modo de ser necessário da justiça, para voltar-se contra um, entre os vários possíveis modos de ela ser. Esse modo de ser específico, objeto da crítica instrumental, refere-se a um conjunto de convicções e conceitos que pode ser hoje "familiar aos juristas, mas nem por isso [é] necessário ou 'natural', 285

É certo que esse modo de ser liberal forjou as instituições que temos hoje, inclusive as judiciárias. Contudo, as tensões da vida em sociedade parecem estar colocando à prova essas instituições, porque não se ajustam mais ao perfil unidirecionado, uniorganizado e vertical de comando e controle representado pelo direito liberal. Sob o prisma substancial, as questões de justiça (inclusive de justiça proporcional, ou seja, distributiva) não parecem mais ser estranhas ao direito. Estão nas leis de consumo, na proteção do meio ambiente, na proibição de lesão nos contratos, nas novas cartas de direitos. O proporcional e o distributivo parecem ter sido reintroduzidos invariavelmente na agenda jurídica plural da sociedade contemporânea, mas as instituições não sabem como operá-los. ${ }^{286}$

Como aponta Lima Lopes, falta "ao pensamento pós-positivista um quadro conceitual que permita tratar do assunto, e foi assim que saiu à procura de substitutos; os princípios jurídicos pareceram a muitos uma tábua de salvação; para outros tratava-se de reestabelecer a comunicação com as ciências sociais; para outros ainda um direito livre e pós-moderno, talvez significando pós-racional, seria a melhor saída. O tema da distribuição voltou também de forma esclarecida na teoria econômica referente às escolhas e aos bens coletivos. Muitas são as correntes que lidam com o tema e o que é relevante para os juristas é que várias, a despeito das diferentes inclinações prático-políticas de cada uma, dão-nos conta de que há bens coletivos". ${ }^{287}$

\footnotetext{
284 Idem, p. 265.

285 Idem, p. 68.

${ }^{286}$ Uma interpretação instigante desse processo está em Philippe Nonet \& Philip Selznick, Law and Society in Transition - Towards Responsive Law.

287 José Reinaldo Lima Lopes, As palavras e a lei.., p. 200.
} 
Será que as instituições são capazes de reagir a esse descompasso estrutural, reinventando seu arsenal instrumental para tentar dar conta de novas tarefas, exigidas em face de novas demandas jurídico-sociais? Minha tese é que sim, e que o exemplo brasileiro pode demonstrar isso. Essa reação não é, evidentemente, organizada. Não é linear, nem consciente ou racionalizada. É difusa, errática e dispersa como toda reação institucional espontânea. Mas penso ser capaz de vê-la claramente, e espero poder demonstrá-lo com este trabalho.

Assim, sob o ponto de vista estrutural, parece-me que o descompasso identificado pela crítica instrumental possa ser explicado sobretudo a partir daquela noção de “conversão", referida por Füller. Deparadas com novos desafios, as instituições não se negam a enfrentá-los, mas o fazem tentando encaixar sua estrutura nas ferramentas de trabalho de que dispõem. À medida em que essas ferramentas produzem resultados erráticos e indesejados, tentam-se forjar novas ferramentas. No caso da distribuição e da comutação, esse problema de inadequação parece revelar-se, sobretudo, pela incapacidade do órgão judiciário de descobrir uma dimensão verdadeiramente coletiva de ação, que não se limite a tratar o coletivo como a soma dos múltiplos individuais, e que não se engaje na tarefa distributiva a partir do caso particular.

Uma pequena referência aos desenvolvimentos recentes da filosofia moral ou política pode ajudar a ilustrar o que quero dizer.

Nada casualmente, a justiça distributiva transformou-se, ao longo do século passado, em um dos temas favoritos da filosofia moral. Como devem ser distribuídos os recursos da sociedade? Igualmente? Não haveria assim desincentivos à ação individual destacada, a qual poderia acabar revertendo em benefício de toda a sociedade? Não seria melhor permitir a apropriação de mais recursos por parte dos mais esforçados, de sorte a gerar maior benefício para todos, inclusive os menos esforçados? Reversamente, não deveriam ser as oportunidades as únicas a conhecer distribuição igualitária, deixando-se os resultados do processo de interação social (desigualdades geradas por maior ou menor talento mercantil, por exemplo) operarem desequilíbrios livremente? É justo o direito à herança? Se não quisermos distribuir igualmente os recursos, como deveriam ser justificadas as desigualdades? Nas escolhas pessoais? Nas necessidades? Nos méritos? Ou nos talentos? 
Essas perguntas circundam teorias distributivas as mais diversas, de viés libertário $^{288}$, igualitário ${ }^{289}$, radicalmente igualitário ${ }^{290}$, utilitarista $^{291}$, $_{\text {etc. }}{ }^{292}$ Um olhar distanciado sobre esse conjunto de teorias permite, contudo, formular uma certa imagem do modus operandi que rege, no plano da filosofia moral, os raciocínios sobre escolhas distrubutivas. Essa imagem, independentemente da formulação específica que se queira dar a uma dada concepção de justiça distributiva, é sempre panorâmica, nunca particular. No jargão da fotografia, é mais uma paisagem que um retrato. Em outras palavras, a análise das várias formulações de justiça acima expostas permite notar que todas elas têm em comum o fato de operarem suas escolhas distributivas no plano macroscópico da sociedade, não no plano microscópio dos indivíduos considerados entre si ou em subgrupos aleatórios. ${ }^{293}$

A razão para isso ser assim é intuitiva. Ninguém pode operar distribuições sem considerar o conjunto inteiro dos possíveis candidatos à fruição do benefício que será distribuído. Ao menos, ninguém pode fazê-lo sem que se perca a racionalidade da operação distributiva, ou sem que se obtenham resultados finais indesejados sob o ponto de vista da racionalidade que se quis aplicar.

Num exemplo cotidiano dos mais banais, é possível tomar o caso de uma professora que pretende dividir sua caixa de chocolates entre os alunos que comparecem a uma dada aula sua.

${ }^{288}$ Cf. Robert Nozick, Anarchy, State and Utopia e Friedrich Hayek, The Constitution of Liberty.

${ }^{289}$ Cf. John Rawls, A Theory of Justice.

${ }^{290}$ Cf. G.A. Cohen, If you're an egalitarian, how come you're so rich?, Amartya K. Sen, Inequality Reexamined e Thomas Nagel, Equality and Partiality.

${ }^{291}$ As doutrinas utilitariastas são mais antigas. V., por exemplo, Jeremy Bentham, The Principles of Morals and Legislation, Stuart Mill, Utilitarianism e Henry Sidgwick, The Method of Ethics.

${ }^{292}$ Para um apanhado geral dessas teorias, v. Will Kymlicka, Contemporary Political Philosophy. V. tb. Alvaro de Vita, Justiça Liberal: Argumentos Liberais Contra o Neoliberalismo e Alvaro de Vita, A Justiça Igualitária e Seus Críticos.

${ }^{293}$ Por isso mesmo a alegoria favorita a esses autores remete à idéia de contrato social. Remete aos náufragos em uma ilha deserta, àqueles que estão numa situação pré-social (o véu da ignorância de Raws, por exemplo) e podem, dessa perspectiva distanciada, funcionando como engenheiros da sociedade que irão empreender, defini-la por completo. Amartya Sen propõe, contudo, uma visão algo diferente desse problema: "In the "totalist" approach that characterizes the standard theories of justice (including Rawls's), incompleteness tends to appear as a failure, or at least as a sign of the unfinished nature of the exercise. Indeed, the survival of incompleteness is some times seen as a defect of a theory of justice, which calls into question the positive assertions that such a theory of makes. In contrast, a theory of justice that makes room for assertive incompleteness allows one to arrive at possibly quite strong judgments, for example about the injustice of continuing famines in a world of prosperity, or of persistently grotesque subjugation of women, and so on, without having to find detailed resolutions of all political and social arrangements. A theory of justice need not try vacuum clean every corner of societal organization.”. Cf. Amartya Sen, What do we want from a theory of justice?, p. 11. 
Se o critério que ela escolher para operar a divisão for estritamente igualitário, ela não terá condições de aplicá-lo na prática enquanto não souber, exatamente, quantos serão os alunos que irão comparecer àquela aula. Ela não pode, por exemplo, atender ao pedido de um de seus alunos feito minutos antes da aula, para que lhe adiante a sua parte. Ela, simplesmente, não saberá qual é a parte que compete àquele aluno, pois ainda não conhece o denominador da divisão.

Atender o aluno em questão pode implicar resultados incompatíveis com a racionalidade distributiva que a professora quer imprimir. Pode ser, por exemplo, que ela superestime o quinhão de seu aluno apressado e guloso, subestimando o número de alunos que irão efetivamente comparecer à sua aula, e acabe dando a ele, assim, maior número de bombons do que ele teria, na verdade, direito. Isso fará com que algum outro aluno, que efetivamente terá comparecido depois à aula, fique com menos bombons do que lhe seria pertinente.

Esse exemplo banal traduz um problema inerente às escolhas distributivas, ligado por sua vez ao problema da dimensão macroscópica de que se tratou atrás. Trata-se de perceber que essas escolhas exigem por parte de quem as toma um tipo de informação bastante acurado sobre o contexto global em que elas são feitas, e esse tipo de informação normalmente extrapola (i) o mero conhecimento da regra distributiva que se quer aplicar, e (ii) o mero conhecimento da situação específica de uma dada pessoa que reclama seu respectivo quinhão, ao argumento de enquadrar-se nos critérios estabelecidos por essa regra (por exemplo, o fato de ser aluno, e de comparecer à aula em questão).

$\mathrm{Na}$ vida real, em que as escolhas distributivas são bem mais complicadas que a repartição de chocolates entre um grupo de pré-escolares, esse déficit de informação pode gerar conseqüências bastante importantes.

Para mostrar isso, tomarei dois exemplos hipotéticos, imaginados à luz de certos casos que passaram já por nossos tribunais. No primeiro deles, um indivíduo "I" está caminhando pelo estacionamento de um supermercado "R" e acaba por tropeçar em uma garrafa de vidro deixada em seu caminho, sofrendo com isso uma queda, que lhe causa uma fratura em um dos joelhos. Esse indivíduo "I" demanda, então, em juízo, a reparação de seu dano, invocando em seu favor a responsabilidade objetiva de " $R$ " pelo evento. 
No segundo exemplo, o mesmo indivíduo "I" é, agora, um aposentado que está há dois meses sem receber sua pensão devida pelo Estado, em virtude de uma greve no serviço de seguridade social. Impossibilitado de honrar com seus compromissos, "I" deixa de pagar pelos serviços de fornecimento de energia elétrica em sua residência, tendo, assim, esses serviços interrompidos. Ele então move uma ação em face de "R", que agora é a companhia responsável pela distribuição de energia elétrica em sua região.

Nessa sua ação, "I" invoca em seu favor o princípio constitucional da continuidade dos serviços públicos, dizendo, ainda, que não tem responsabilidade sobre a falta de pagamento de suas contas, pois é o próprio Estado que, descumprindo suas obrigações, priva-lhe dos meios necessários para realizar o pagamento.

"I" argumenta, ainda, que o fornecimento de energia elétrica é um serviço público, cujo titular é o Estado (ainda que tal serviço tenha sua execução transferida a um particular) e que, dessa forma, não faz sentido que uma mesma pessoa (ou seja, o Estado) lhe esteja exigindo o cumprimento de suas obrigações sem cumprir, em contrapartida, as prestações que também lhe são devidas.

Note-se que os dois problemas propostos acima estão configurados, claramente, como conflitos de justiça retributiva.

Em um deles, busca-se reparação por um dano. Está-se no campo da responsabilidade civil, que é, tradicionalmente, um dos campos mais relacionados à noção de comutação (dano - indenização = zero), tão ligada à idéia mesma de justiça retributiva.

No outro exemplo, o fundamento último da pretensão de "I" é regra clássica do direito dos contratos (ninguém pode exigir uma prestação de outra pessoa sem que se disponha a cumprir a sua). É, também, exemplo claro de situação em que opera a noção de comutação de forma plena (as prestações dos contratantes devem ser realizadas ambas para que a contratação seja para os dois uma transação de soma zero).

As situações dadas como exemplo causariam, no entanto, espécie ao estudante médio de um curso de direito, e apresentariam, certamente, alguma dificuldade para o juiz que as fosse analisar. Procurarei mostrar, abaixo, que isso acontece porque elas referem, na verdade, problemas distributivos, travestidos de problemas de justiça retributiva. Ou, como anotou Füller referindo-se aos conflitos policêntricos, porque as noções de retribuição e 
comutação não se opõem por uma linha demarcatória, mas, muitas vezes, por uma escala de grau. ${ }^{294}$

Com esses dois exemplos procurarei demonstrar, também, como operam algumas críticas normalmente direcionadas à definição de políticas públicas pelo judiciário, bem como à própria utilização de estratagemas indiretos de redistribuição de renda ou riscos.

Comecemos pelo exemplo número um e assumamos, nesse ponto, que exista, de antemão, no ordenamento jurídico, uma regra que ampare claramente a pretensão de "I", imputando a responsabilidade pelo acidente sofrido à empresa " $\mathrm{R}$ ”, objetivamente.

Talvez essa proposição cause alguma estranheza, sobretudo porque nossa tendência seria inicialmente a de negar a responsabilidade mesmo diante de regras tradicionais de responsabilidade objetiva. Isso ocorre, creio, porque essa forma de responsabilidade civil, tal como consagrou-se em inúmeras legislações, inclusive na nossa teoria do risco administrativo ou comercial, ou mesmo no Código de Defesa do Consumidor, não se afasta, inteiramente, da noção de culpa, abrigando espaços para que se fale em culpa exclusiva da vítima, fato de terceiro e assim por diante. Diz-se, nesse sentido, que a identificação das várias modalidades de responsabilidade civil com uma teoria fundada na idéia de risco integral é rara nos ordenamentos, encontrando apenas alguns poucos exemplos. ${ }^{295}$ Todavia, imaginemos que se trata, sim, de uma regra que imponha a assunção integral do risco por parte do empresário.

O que essa regra está fazendo é, na verdade, promover uma redistribuição dos riscos normalmente presentes na sociedade em virtude de uma dada racionalidade específica. Aliás, bem observadas, quase todas as regras que circundam a responsabilidade civil clássica já continham em si juízos distributivos semelhantes, por meio dos quais o legislador fazia escolhas quanto à alocação de riscos. ${ }^{296}$ A idéia de responsabilidade objetiva potencializa isso. Ela, indiretamente, faz concentrar os riscos dispersos pela

294 "[I]f it is important to see clearly what a polycentric problem is, it is equally important to realize that the distinction involved is often a matter of degree. There are polycentric elements in almost ali problems submitted to adjudication. A decision may act as a precedent, often an awkward one, in some situation not foreseen by the arbiter" (Lon Füller, The Forms and Limits of Adjudication, p. 397). É essa, basicamente, a hipótese de que passo a tratar adiante.

${ }^{295}$ No Brasil, seria o caso da responsabilidade por acidente nuclear, por exemplo.

${ }^{296}$ V. a respeito Charles Sabel e William Simon, Destabilization Rights, p. 1.057. Segundo os autores, "In areas such as tort and bankruptcy... the common law is intended to operate as much as a system of social regulation as one of dispute resolution" (idem, ibidem). 
sociedade em algumas pessoas em particular, fazendo-o em virtude da assunção de que essas pessoas, por características próprias suas (poder econômico, por exemplo), tenham melhores condições de enfrentar esses riscos. ${ }^{297}$

Em nosso exemplo, seria possível imaginar uma decisão do legislador no sentido de transferir os riscos de acidentes banais, tanto quanto possível, dos indivíduos para os agentes produtivos, uma vez que os agentes produtivos têm a capacidade e o interesse, se responsabilizados por esses riscos, de segurá-los. Já o indivíduo não tem nem a capacidade nem o interesse de segurar-se contra pequenos riscos a que possa, eventualmente, estar exposto. Ele irá segurar-se apenas contra grandes riscos, como o roubo de seu carro ou o incêndio de sua casa. O pequeno risco de sofrer um acidente em um estacionamento de supermercado é, para o consumidor, irrelevante demais para ser segurado. Já para o próprio supermercado pode fazer sentido cobrir-se contra indenizações que ele tenha que pagar a seus consumidores em situações semelhantes. Dessa forma, o desenvolvimento de um mercado complexo de seguros e a percepção do agente econômico como um possível agente de concentração de riscos que antes estariam esparsos e não seriam seguráveis parece estar na base de boa parte das regras contemporâneas de responsabilidade objetiva. São regras, portanto, de redistribuição de riscos. Em nosso exemplo, ao aplicar a lei o juiz responsável pelo caso irá transferir os riscos de "I" (na verdade de todo o conjunto de possíveis indivíduos "I") para "R", para que este depois os transfira a uma companhia seguradora "CS". Esse esquema é retratado na Figura 01abaixo.

(Figura 01)

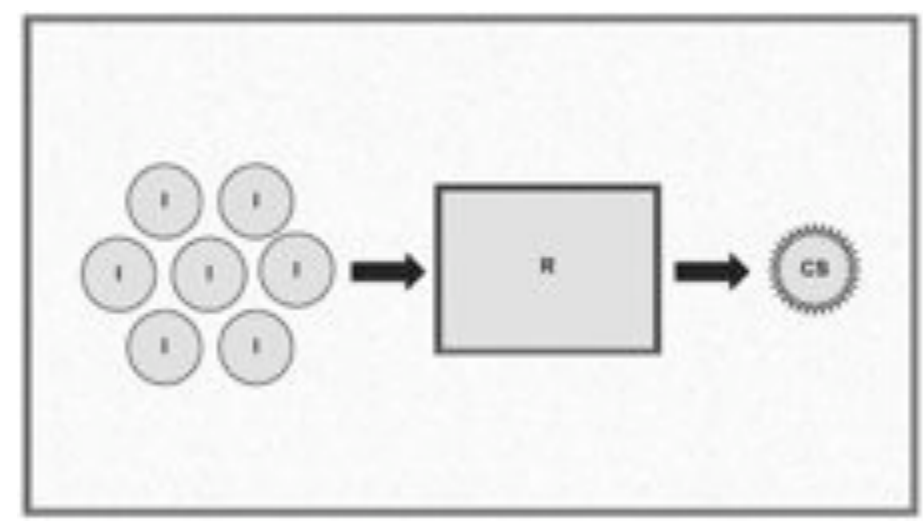

Nesse exemplo, ainda que a regra jurídica imputando o risco integral a "R" não exista previamente no ordenamento jurídico, não seria muito difícil a nosso juiz criá-la,

${ }^{297}$ V. tb. Lawrence Friedman, Total Justice, passim. 
utilizando a racionalidade exposta acima para interpretar as regras existentes acerca da responsabilidade civil. Partindo do princípio de que sua decisão seria no futuro universalizada, ou seja, que se tornaria um precedente invocável e aplicável a casos semelhantes, o resultado desejado seria, muito provavelmente, atingido: a companhia " $R$ ", enfrentando sua primeira derrota, iria segurar-se contra potenciais eventos semelhantes que pudessem acontecer no futuro, e o mesmo iriam fazer todas as outras companhias existentes no mercado. Ao assim fazerem, elas estariam operando a transferência de riscos desejada pelo juiz, e o efeito desejado em sua decisão seria implementado na prática.

Seria possível objetar, nesse mesmo exemplo, que o custo do seguro que " $\mathrm{R}$ " precisaria contratar acabaria sendo repassado ao preço de seus produtos e que, com isso, tanto "I" quanto todos os demais consumidores iriam acabar arcando com esse preço. Esta não é, todavia, uma objeção verdadeira. Se isso acontecer, a racionalidade suportada na decisão em questão ver-se-ia confirmada. Isso significaria que " $R$ " estaria agindo no caso como um ótimo agente de gestão e distribuição de riscos. Ele distribui, indiretamente, o risco alocado individualmente em um consumidor para todos os consumidores, e acaba contratando, por eles, um seguro que, individualmente, nenhum deles conseguiria contratar. E tudo isso sem sofrer dano algum, já que ele conseguiria, na hipótese aventada, repassar para os próprios consumidores todo o custo em que incorre para gerir os riscos deles. O problema surge, na verdade, quando o suposto agente de distribuição dos riscos não é capaz de desempenhar esse seu papel adequadamente.

Nesses casos, a racionalidade distributiva prevista na lei ou na decisão judicial corre sério risco de se perder. Para compreender essa possibilidade, avançaremos para o exemplo número dois mencionado acima.

Agora, como dito, "I" é um aposentado que deixou de receber sua pensão durante dois meses, em virtude de uma greve no poder público federal. Ele usa esse fato como argumento em sua demanda judicial em face de "R", que agora é a distribuidora de energia elétrica que serve a sua residência.

O argumento de "I" está moldado em termos de justiça retributiva, da seguinte forma: (i) o Estado é, no final das contas, o verdadeiro titular do dever consubstanciado na prestação do serviço público, (ii) o Estado é, também, devedor das prestações que, uma vez pagas, permitiriam a "I" a retribuição pelo serviço público que lhe é prestado, (iii) o Estado 
não cumpriu com sua obrigação mencionada no item anterior, logo (iv) o Estado (ou a companhia que o representa) não pode exigir de "I" a retribuição pelo serviço público prestado, ou, ao menos, não pode punir "I" pela falta de retribuição enquanto permanecer ele, o próprio Estado, inadimplente com sua obrigação anterior.

Para facilitar o exemplo, imaginemos que não existe, no caso, qualquer regra jurídica específica e anterior disciplinando o assunto. E imaginemos que nosso juiz não se convença, em absoluto, pelo argumento de soma zero oferecido pelo autor, mas, ao mesmo tempo, compreenda que o acolhimento de seu pedido se faz necessário por ser uma medida de justiça social.

Nosso juiz poderá traduzir seu senso inicial de justiça social em uma racionalidade distributiva medianamente razoável. Dirá, a exemplo do que se fez na hipótese anterior, não ser medida de equidade deixar concentrar-se em "I" um risco que é para ele inevitável e que, de outro modo, poderia ser repartido por toda a sociedade (o risco de inadimplência, pelo Estado, dos valores atinentes à sua aposentadoria).

Suportado nesse raciocínio, nosso juiz acolhe o pedido de "I", fazendo, indiretamente, com que a empresa " $R$ " tenha que arcar, ela mesma, com os custos da distribuição de energia elétrica a "I". Usando as mesmas palavras que usamos anteriormente, nosso juiz transfere o risco da inadimplência do Estado de "I" para "R", na esperança de que "R", por sua vez, redistribua esse risco igualmente pela sociedade, aumentando o valor geral de suas tarifas, proporcionalmente.

"R" funciona, de novo, como um agente de distribuição do risco. Se puder desempenhar adequadamente essa sua função, irá distribuir o risco de "I" entre todos os demais indivíduos "I" que compõem a sociedade, igualmente.

Alguém poderia objetar que o risco de inadimplência da seguridade social deveria ser suportado pelo próprio Estado, por meio de um fundo especialmente criado para isso, ao invés de ser repassado para uma empresa particular, que simplesmente explora o serviço de distribuição de energia elétrica. Segundo essa crítica, mesmo em se admitindo a racionalidade distributiva da decisão, seria preciso perceber que o Estado tem muito melhores condições de distribuir riscos na sociedade que uma empresa particular. Contudo, se algumas condições práticas pudessem ser satisfeitas, optar por uma ou outra solução 
(especificamente em relação à utilização desse serviço público) seria completamente irrelevante.

Essas condições são, especialmente, as seguintes: (i) tanto o Estado "E" quanto a companhia " $\mathrm{R}$ " precisariam ser agentes de distribuição de risco perfeitamente eficientes, isto é, precisariam ser capazes de passar adiante cem por cento do custo que lhes é atribuído e (ii) o universo das pessoas que recebem os riscos de um ou outro desses agentes deve ser idêntico (os contribuintes que suportariam o risco alocado no Estado, através do fundo, deveriam ser também consumidores dos serviços de energia prestados por " $\mathrm{R}$ ", e vice-versa).

Chamando-se de " $\mathrm{I}_{1}$ " ao indivíduo que deixa de pagar especificamente sua conta de energia elétrica, e de " $\mathrm{I}_{2}$ ”a todos os demais indivíduos que, ao final, acabam dividindo com ele o risco originado na inadimplência dos serviços de previdência social, essa hipótese poderia ser retratada pela Figura 02, abaixo.

A racionalidade distributiva contida na decisão judicial se perde, contudo, se as condições referidas acima não forem satisfeitas. Pode acontecer, por exemplo, que o conjunto dos membros da sociedade seja maior que o conjunto dos consumidores de "R".

(Figura 02)

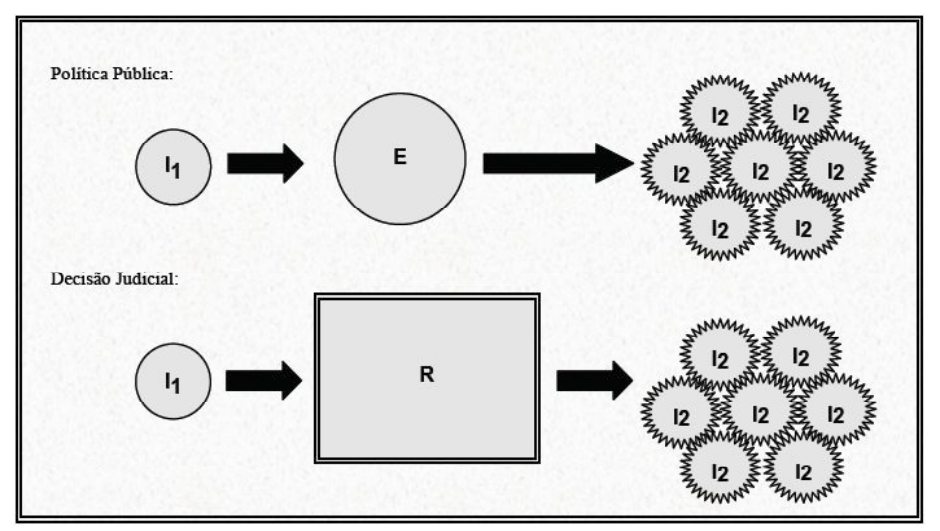

Nesse caso, a decisão provocará um resultado incompatível com a racionalidade distributiva que quis imprimir, tornando-se assim injusta. Ela terá alocado os riscos de " $\mathrm{I}_{1}$ " apenas em um conjunto delimitado e completamente aleatório de membros da sociedade (os indivíduos " $\mathrm{I}_{2}$ ”, que calham de ser também consumidores dos serviços de "R"), sem 
que haja razão alguma, moral ou de justiça distributiva, a justificar que esses indivíduos suportem, sozinhos, esse ônus.

Nessa hipótese, vários outros membros da sociedade (digamos, os indivíduos "I $\mathrm{I}_{3}$ ”) ficariam livres de ônus equivalente, produzindo-se uma situação de injustiça fundada no tratamento desigual de pessoas que, para os propósitos em questão, deveriam estar na mesmíssima situação. Aqui, usar o Estado como agente de distribuição dos riscos de "I 1 ", por meio do fundo sugerido acima, teria sido mais racional. A decisão judicial produziu injustiça, como se pode esquematizar na Figura 03 abaixo.

Duas outras situações ainda piores podem acontecer. Pode ocorrer que a racionalidade distributiva invocada pela decisão judicial tivesse por pressuposto uma afirmação do seguinte tipo: não são todos os membros da sociedade que devem suportar os riscos de " $I_{1}$ ", mas apenas a parcela mais rica da população, já que essa parcela paga proporcionalmente menos impostos que os mais pobres como " $I_{1}$ ", e tem melhores condições para absorver os riscos daqueles que dependem da aposentadoria do Estado. E pode ocorrer, também, que justamente essas pessoas não utilizem os serviços de "R", por exemplo, porque preferem instalar em suas residências modernos conversores de energia solar em energia elétrica.

(Figura 03)

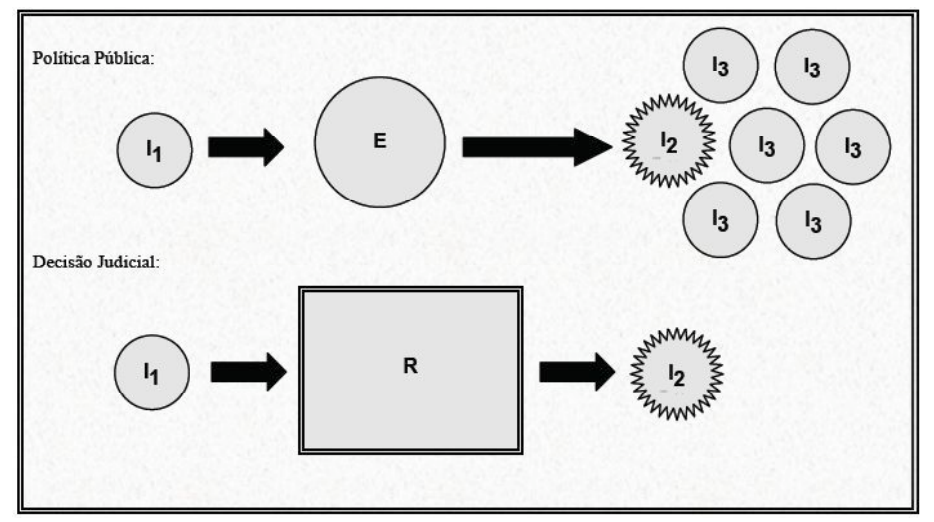

Nessa inventada hipótese, o resultado da decisão judicial seria ainda mais incompatível com a racionalidade nela prevista: o risco seria transferido às pessoas erradas. Novamente, teria sido melhor criar uma política estatal baseada em um fundo 
destinado a suportar o risco, fazendo, por exemplo, com que o fundo fosse custeado por um imposto incidente apenas sobre grandes fortunas ${ }^{298}$.

A Figura 04, abaixo, contempla essa hipótese de alocação inteiramente errada.

(Figura 04)

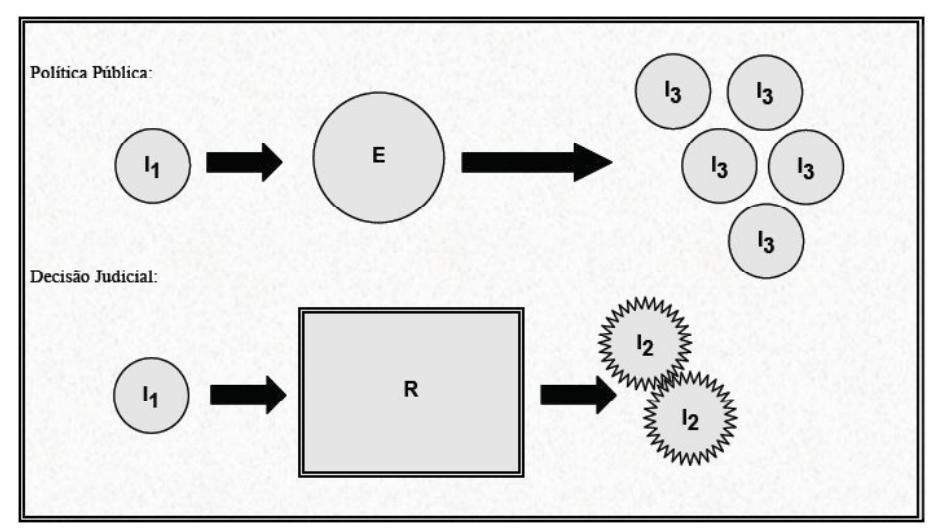

Derradeiramente, pode ainda acontecer que "R" seja, simplesmente, um agente de distribuição de riscos altamente ineficiente, e não consiga, em absoluto, repassar os custos da inadimplência de "I $\mathrm{I}_{1}$ " para seus consumidores. Isso pode acontecer porque seus preços são controlados pelo governo, ou porque "R" atua em um mercado competitivo e seus concorrentes não receberam encargos semelhantes a esse que lhe é imputado, o que lhe impede, de todo o modo, de subir seus preços.

Nessa hipótese, a decisão judicial (i) não irá atingir seus objetivos distributivos e (ii) irá tornar " $\mathrm{R}$ " um agente econômico menos eficiente do que ele era inicialmente, afetando condições de competição e alterando indesejadamente a dinâmica do mercado em que "R" atua. A hipótese de "R" como um agente de distribuição de riscos altamente ineficiente é contemplada na última figura relativo a esses exemplos todos (Figura 05), abaixo reproduzido.

Esses exemplos todos, ainda que vários e talvez longos, procuram ilustrar praticamente alguns dos problemas que envolvem os mecanismos distributivos.

Mostram, em primeiro lugar, como pode ser difícil, em certos casos, ignorar (ou mesmo separar) o efeito distributivo de certas decisões que aparentam ser, em um primeiro

\footnotetext{
${ }^{298}$ Todos esses exemplos são, evidentemente, didáticos e hipotéticos, e não se preocupam com sua estrita compatibilidade no que diz respeito às regras jurídicas vigentes no país a respeito das várias matérias neles abordadas.
} 
olhar, fundadas em critérios de justiça retributiva. Novamente, remeto à idéia de Füller no sentido de serem os problemas bilaterais e policêntricos algo como modelos ideais, cada qual remetendo a um oposto em uma escala na qual se colocam, em graus mais próximos de um ou outro modelo, mas sempre intermediários entre eles, as questões realmente existentes na sociedade.

(Figura 05)

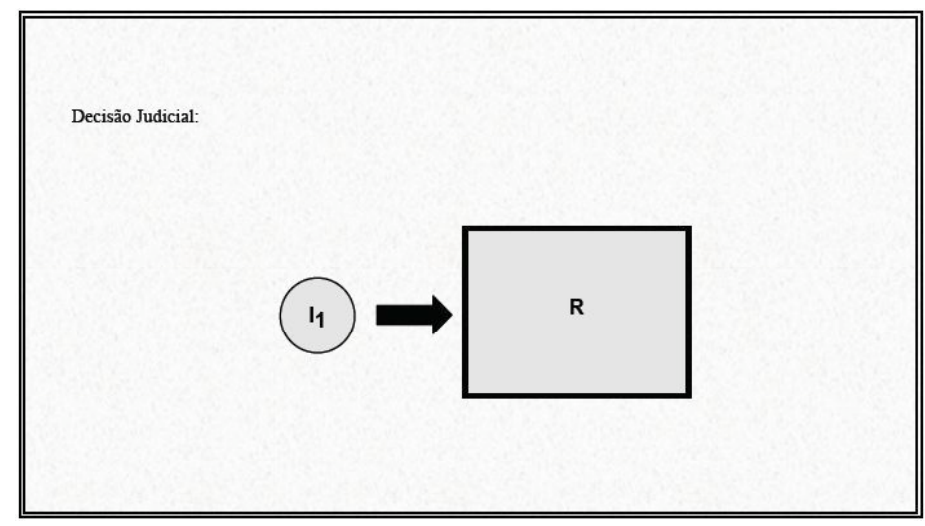

Ainda em relação a essas decisões aparentemente fundadas em critérios retributivos, mas com efeitos distributivos, fica claro que a manutenção da racionalidade distributiva nelas inserida depende, intrinsecamente, de sua aplicação uniforme a todos os casos semelhantes.

Em nosso exemplo do supermercado, essa racionalidade se perde se os tribunais de São Paulo começarem a entender " $R$ " objetivamente responsável pelos acidentes ocorridos em seu recinto, mas os do Recife não. Nesse caso, cidadãos "I", que sofrem acidentes iguais, estarão sendo injustamente discriminados quanto à necessidade de suportarem, ou não, os custos desses acidentes. Pior que isso, pode acontecer que aquele que não conseguiu vitória judicial tenha que suportar, em adição aos próprios custos, também aqueles dos demais que ganharam suas ações, fazendo-o através do pagamento de preços mais elevados no supermercado. Fica claro, aqui, que a racionalidade distributiva apenas pode ser garantida nesses casos por meio de um sistema de precedentes mais ou menos organizado, ou por alguma forma eficiente de uniformização de jurisprudência em nível nacional.

Além disso, os exemplos acima mostram os riscos que estão por trás dos expedientes distributivos indiretos (utilizar a empresa $\mathrm{R}$ para distribuir os riscos do consumidor $\mathrm{I}_{1}$ pela sociedade, por exemplo). 
Nesses casos, erros de avaliação quanto ao impacto das políticas tendem, no mais das vezes, a fazer com que a racionalidade redistributiva desejada se perca. Nos exemplos acima, um desses erros é representado pela tentativa de associar "membros da sociedade" a “consumidores de energia elétrica”. São também exemplos disso as tentativas de estabelecer progressividade na cobrança de impostos indiretos (taxar mais a venda de champanha que a venda de feijão, por exemplo), ou de tomar decisões tecnico-regulatórias com base em argumentos afirmadamente redistributivos (cobrar tarifas mais altas pelas ligações interurbanas que pelas ligações locais, ou cobrar mais pelas ligações mais longas que pelas mais curtas, com base na assunção de serem os ricos aqueles que, normalmente, falam mais tempo ao telefone, utilizando-se mais de interurbanos).

Agora pergunta-se: o que esses expedientes indiretos têm a ver com as cortes de justiça? Muito, porque, em primeiro lugar, são quase sempre indiretos os expedientes redistributivos implementados judicialmente ${ }^{299}$. Aliás, segundo aponta a literatura especializada, são quase sempre indiretos todos os expedientes redistributivos tentados pelo direito (função social da propriedade, proteção dos bens de família e dos necessários à própria subsistência, proteção dos consumidores, etc.). Não é pequena a literatura de law and economics que procura demonstrar o caráter regressivo de todos esses expedientes ${ }^{300}$, mostrando o equívoco que se esconde por trás da pretensa assimilação das categorias "pobres" e "consumidores", ou como a proteção dos bens de família torna o crédito mais caro à população mais pobre e incapaz de oferecer seus poucos bens em garantia de suas dívidas. $^{301}$

Em segundo lugar, tais expedientes redistributivos indiretos redundam regressivos, em geral, por conta de déficits de informação. É, muitas vezes, a falta de informação completa acerca do contexto em que a decisão produzirá seus efeitos que gera o erro de avaliação de impacto que conduz, por sua vez, ao atingimento de um resultado contrário àquele originalmente pretendido. ${ }^{302} \mathrm{E}$ as cortes de justiça estão, em suas decisões,

\footnotetext{
${ }^{299}$ Uma exceção poderia ser, v.g., a invalidação judicial de uma lei atinente à cobrança de imposto de renda, por via de controle concentrado, ao argumento de não ter sido respeitado o princípio de progressividade estabelecido no artigo 153, parágrafo $2^{\circ}$, I, da Constituição Federal.

${ }^{300}$ V. Cass R. Sunstein, Free Markets and Social Justice, New York: Owford University Press, 1997.

${ }^{301}$ V. Fernando Cantuarias, Robin Hood Reloaded: Taking Money from the Rich to Steal from the Poor.

302 Muitas vezes o erro está em não prever as manobras de que dispõem os agentes afetados pela decisão distributiva para escapar de seus custos (por exemplo, redirecionamento ou retração de investimentos, repasse dos custos incorridos para os preços, etc.)
} 
intrinsecamente sujeitas a esses déficits de informação. Isso acontece por três motivos principais.

Primeiro, porque as informações relativas aos impactos produzidos pela decisão não são muitas vezes identificadas como juridicamente relevantes. Com base na tradição descrita anteriormente, ligada à separação das esferas do direito e da política na tradição liberal, tende-se a reconhecer como jurídico apenas o argumento principiológico, mas não aquele conseqüencialista. $\mathrm{Na}$ formulação do "direito do porvir"303, contudo, a conseqüência é tão importante quanto o princípio.

Segundo, porque tais informações dependem de inputs especializados e variados, que somente podem ser adquiridos através de um processo complexo de franquia de participação a um número bastante disperso de pessoas. A estrutura bilateral do processo judicial, como identificou Füller, de fato dificulta a obtenção desse tipo de informação, ainda que o processo coletivo brasileiro esteja tentando, paulatinamente, responder a essas dificuldades. Tal obtenção de informação ainda é impactada pelos esquemas tradicionais de prova judicial, que em geral são retrospectivos e não prospectivos, conforme antes apontado. $^{304}$

Finalmente, porque a avaliação do impacto das decisões distributivas apenas é possível quando essas decisões são somadas conscientemente, ou seja, com vistas ao conjunto da sociedade, e não a certos indivíduos ou grupos de interesse particularmente considerados. Por isso, decisões de efeito distributivo indireto tendem a ser muito mais irracionais quando tomadas no contexto de conflitos individuais, que veiculem apenas parte do problema distributivo, que quando tomadas no contexto coletivo, em que a consideração de impactos sociais é necessária e estes são muito mais evidentes. ${ }^{305}$

${ }^{303}$ V. Marcos Paulo Verissimo, Aproximação sistemática ao controle judicial das agências de regulação econômica no Brasil, p. 138.

${ }^{304}$ Referi antes, a esse respeito, Lon Füller, The Forms and Limits of Adjudication, p. 336. Todavia, especialmente no que se refere à prova, mais completa é a análise de Donald L. Horowits, The Courts and Social Policy, p. 45 e ss. Cf., especialmente, a distinção que Horowits faz entre "fatos históricos" e "fatos sociais".

${ }^{305}$ Um exemplo disso é dado pela decisão proferida pelo Ministro Edson Vidigal, do Superior Tribunal de Justiça, por ocasião do julgamento da suspensão de segurança n. ${ }^{\circ} 1.408$ - SP (2004/0123187-5). O caso envolvia uma senhora portadora de câncer de pulmão, que demandava do Secretário de Saúde do Estado de São Paulo o fornecimento de um certo medicamento necessário ao seu tratamento, àquela época ainda não registrado no país. $\mathrm{O}$ fundamento invocado pela autora consistiu no direito à saúde, constitucionalmente assegurado. A Secretaria de Saúde, em contrapartida, afirmou, segundo o Min. 
Como apontam Sunstein, Kahneman, Schkade e Ritov, “quando as pessoas fazem julgamentos jurídicos ou morais isoladamente, elas produzem um padrão de resultados que elas mesmas rejeitariam se pudessem, simplesmente, enxergá-lo de forma global". ${ }^{306}$

\section{III}

\section{A TRANSIÇ̃̃o do DIREITO PARA O INTERESSE}

Espero que a discussão acima, relativa aos domínios da justiça distributiva e retributiva, possa ter esclarecido alguns dos principais pontos referidos pela crítica instrumental. Espero que ela possa ter, também, ajudado a situar essa crítica em seu espaço e tempo respectivos. Prosseguindo nessa mesma tarefa, passo a trabalhar, agora, sobre uma outra dicotomia: a do interesse em contraposição ao direito subjetivo.

Sem querer entrar em discussões infindáveis de teoria jurídica sobre a caracterização precisa dessas categorias, imagino que seja possível trabalhá-las, novamente, como modelos, tipos ideais ou pólos opostos em uma outra escala de graus: a escala das posições de vantagem protegidas mais ou menos intensamente pelo direito.

Tenho, com a discussão dessas categorias, duplo objetivo.

Vidigal, seu temor quanto ao 'efeito multiplicador da decisão, destacando que "a decisão hostilizada representa grave lesão à saúde pública (porquanto obriga o Estado, de forma ilegal e indiscriminada, ao fornecimento de um medicamento sem comprovação de eficácia, cujo uso é vedado, colocando em risco os pacientes que o utilizarem, dados os potenciais riscos de efeitos adversos ainda não totalmente pesquisados); à ordem pública (já que dá margem a outras decisões no mesmo sentido, com frontal infringência à legislação federal de regência" e, finalmente, às finanças públicas (porque implica despesa com remédio em fase experimental).' Esse argumento, todavia, não foi acolhido pelo Ministro, sob a justificativa de não ser possível concluir que 'o fornecimento do medicamento a uma única paciente possa causar lesão de conseqüências significativas e desastrosas à economia do Estado de São Paulo.' Além disso, disse o Ministro que o efeito multiplicador da decisão seria hipotético, pois não haveria prova de que, 'animadas pela decisão recorrida, tenham sido ajuizadas outras ações com igual pretensão.' A decisão, tomada para o caso particular, tem problemas de racionalidade distributiva sérios. Aparentemente, parece assumir que sua racionalidade somente se preserva se o comando respectivo não puder ser universalizado (do contrário estaria presente, pois, o "efeito multiplicador" que geraria a lesão coletiva). Ora, decisões judiciais não universalisáveis não atendem o primeiro dos postulados de justiça, consistente no imperativo de isonomia. Se usada como precedente, a decisão geraria, provavelmente, um dano que o seu prolator não parece admitir como legítimo. Em outras palavras, o texto dá a entender que a solução seria outra se a demanda fosse coletiva, e se a decisão gerasse um direito igual a todas as pessoas que estão na mesma situação da autora. A dimensão individual, nesse caso, escondeu o problema distributivo, e gerou, aparentemente, uma decisão que não seria tomada no plano coletivo.

${ }^{306}$ Cf. Cass R. Sunstein, Daniel Kahneman, David Schkade and Ilana Ritov, Predictably Incoherent Judgments. 
Em primeiro lugar, procuro mostrar como a tradição liberal, ao associar as noções de retribuição e direito, acabou também por eleger o direito subjetivo como única posição de vantagem judicializável. Nesse processo, o mero interesse (moral, econômico, político), quando não conseguiu traduzir-se no jogo parlamentar em uma faculdade de exigir diretamente certos comportamentos alheios, ficou afastado para campos outros que não o jurídico (campos da política, por exemplo, ou das relações de mercado). ${ }^{307}$

Em decorrência disso, a proteção judicial das posições de vantagem estruturou-se, na tradição liberal, de sorte a instrumentalizar o exercício de direitos subjetivos, e acaba tendo dificuldades, hoje, para operar a proteção de outras formas mais frouxas de interesse sobre certos bens, por falta de instrumentos concebidos para tanto.

Isso conduz ao segundo objetivo dessa análise. Quero também demonstrar que a introdução (ou reintrodução) de problemas distributivos no direito colocou o interesse em posição de destaque entre as posições jurídicas, e que isso gera outra boa porção dos desajustes estruturais referidos pela crítica instrumental. $\mathrm{O}$ processo judicial é aparelhado para proteger direitos, mas não age de forma tão eficiente com os interesses. Quando esses passam a ser judicializados mais intensamente que aqueles (isso acontece, creio, no plano dos litígios coletivos, especialmente daqueles ligados a bens comuns, verdadeiramnte indivisíveis), as respostas judiciais tornam-se substancialmente mais erráticas, desajustadas, incompletas.

De uma parte considerável desses bens comuns, indivisíveis, fruíveis por toda a coletividade, o Código Civil brasileiro de 1916, por exemplo, já cuidava. Como ele o fazia? Em seu artigo 66, caracterizava esses bens como "bens de uso comum do povo", enquadrando-se nessa categoria os "mares, rios, estradas, ruas e praças". A célebre questão de Mauro Cappelletti, “a quem pertence o ar que respiro? "308 teria, portanto, uma resposta "simples" no direito positivo brasileiro: ao Estado. ${ }^{309}$ É certo que o Estado não tem sobre esses bens o mesmo ius dominus que tem, v.g., sobre seus bens dominiais. Algumas teorias jurídicas procuraram, por isso, enquadrar essa propriedade como uma propriedade sui generis, ou mesmo ver no Estado mero administrador desse bens. De toda sorte, mesmo

\footnotetext{
307 Vale lembrar, a propósito, as considerações de Botelho de Mesquita, referidas no item I desta parte. Mas a afirmação comporta, evidentemente, exceções. O campo do direito de família é um exemplo delas.

${ }^{308}$ Cf. Mauro Cappelletti, Formações Sociais e Interesses Coletivos Diante da Justiça Civil, p. 135.

309 V. J.M. de Carvalho Santos, Código Civil Brasileiro Interpretado, vol. II, p. 103.
} 
nessa função de administrador, como deveria portar-se o Estado na tutela de tais bens coletivos? Segundo o interesse público, diria a doutrina de direito administrativo. "O" interesse público, certo, único e identificado, emanado provavelmente de uma sociedade que não diverge nunca quanto aos seus objetivos comuns.

O direito liberal acostumou-se a trabalhar dentro da dicotomia público $v$. privado. ${ }^{310} \mathrm{Na}$ esfera privada valem os direitos, apropriados pelos cidadãos. Na esfera pública (da política, da discricionariedade administrativa) trafegam os simples interesses, sem proteção jurídica específica. Não há direito regulando a alocação individual de bens coletivos. Estes são dispostos segundo o interesse público, conhecido pelo Estado. Até por isso, a distinção entre direitos e interesses foi e ainda é utilizada por diversos direitos europeus para deliminar os tipos de posição de vantagem passíveis de afirmação diante da justiça comum (direitos) e aqueles somente apresentáveis à justiça administrativa (interesses). ${ }^{311}$

Ora, o que a sociedade contemporânea faz é justamente destruir as fronteiras entre o público e o privado. Esses reflexos são sentidos intensamente no campo do direito e a própria noção de interesse público vai perdendo sua força persuasiva diante da constatação de que, em uma sociedade plural, a regra é a divergência quanto aos fins comuns, é o desacordo quanto à alocação de recursos escassos e à utilização de bens indivisíveis, não a convergência ${ }^{312}$. Lutam, numa sociedade assim, os interesses "de uma comunidade em ter uma fábrica gerando empregos e outra interessada em fechar a mesma fábrica, por ser altamente poluidora".313 Mais que isso, ambos esses interesses conseguem, hoje, apresentar-se sob a forma de discursos jurídicos, ao amparo de uma constituição generosa que consagra, a um só tempo, o "valor social do trabalho,"314 bem como o "direito social" de trabalhar ${ }^{315}$, e a "proteção do meio ambiente", 316 dizendo que a União deve "combater a poluição em qualquer de suas formas". 317

\footnotetext{
310 Cf. Mauro Capelletti, Formações Sociais..., p. 132-136.

311 Essa ainda é, por exemplo, a opção da Constituição Italiana, cujo artigo 103 dispõe o seguinte: "Il Consiglio di Stato e gli altri organi di giustizia amministrativa hanno giurisdizione per la tutela nei confronti della pubblica amministrazione degli interessi legittimi e, in particolari materie indicate dalla legge, anche dei diritti soggettivi.".

${ }^{312}$ V., a respeito, Floriano de Azevedo Marques, Regulação e Interesses Públicos, passim.

313 Cf. José Reinaldo Lima Lopes, Justiça e Poder Judiciário..., p. 26-27

314 Constituição Federal, artigo $1^{\circ}$, inciso VI.

${ }^{315}$ Constituição Federal, artigo $6^{\circ}$.
} 
Como anota Joel Grossman, a estrutura policêntrica dos conflitos políticos está intrinsecamente relacionada à noção de interesse, em contrapartida à noção de direitos, e é também por isso que a judicialização daqueles está (i) mudando, progressivamente, o modo de ser da justiça civil, e (ii) gerando, simultaneamente, várias das perplexidades sentidas pela crítica instrumental, sobretudo quando ocorrem problemas de "conversão" semelhantes àqueles antevistos por Füller.

Conforme Grossman, “a estrutura bipolar da adjudicação ainda define o padrão ordinário do contencioso civil que ocupa a maior parte do trabalho das cortes de justiça. Mas, à medida em que as cortes têm se tornado crescentemente receptivas a questões policêntricas de política social, novas formas de adjudicação se desenvolveram. Emergiu uma visão mais flexível sobre o modo como "interesses" deveriam ser representados, e sobre quais interesses seriam legalmente cognocíveis - não suplantando mas suplementando o núcleo da visão lockeana de direito individual que forma a base do sistema adversarial tradicional. Com o Estado administrativo veio maior ênfase nos interesses. Agências administrativas, por exemplo, freqüentemente lidam com direitos individuais e com o relacionamento entre cidadãos e governo como um problema de interesses e de utilidade social, ao passo em que as cortes adaptaram-se à nova ordem endereçando interesses através da lente mais tradicional dos direitos individuais." 318

Como se estruturam, no entanto, os interesses? Em que essa estrutura difere daquela própria aos direitos subjetivos? Quais as diferenças funcionais entre essas categorias? Como, finalmente, se dá a passagem do direito subjetivo para o interesse, como posição de vantagem típica nas sociedades contemporâneas?

Para responder a essas questões, tomarei de empréstimo, adiante, a análise efetivada por François Ost em Droit et Interet. ${ }^{319}$

Ost começa seu tratabalho dizendo que, "ao benefício de uma lógica binária de tudo ou nada, lógica de inclusão ou de exclusão, o interesse é recebido como direito, ou então ele não é nada de juridicamente pertinente. Trata-se da consagração sob forma de um

\footnotetext{
316 Constituição Federal, artigo 23, inciso VI, artigo 129, inciso III.

317 Constituição Federal, artigo 23, inciso VI.

318 Cf. Joel B. Grossman, Judicial Legitimacy and the Role of Courts: Shapiro's Courts, p. 217.

${ }^{319}$ Cf. François Ost, Entre droit et non-droit, l'intérêt. Essai sur les fonctions qu'exerce la notion d'intérêt en droit privé.
} 
direito subjetivo reconhecido e protegido, ou o banimento para os limbos do não direito." No diagnóstico de Ost, o interesse, na teoria contemporânea do direito, em geral não conhece existência jurídica própria, status de categoria apartada. ${ }^{320}$

$\mathrm{O}$ autor vê quatro notas marcantes e correlacionadas na figura do interesse, que podem distingui-lo a priori, talvez, do direito subjetivo. São elas a onipresença, a imprecisão, a flexibilidade e subversividade. ${ }^{321}$

O interesse está na base de qualquer direito subjetivo, mas não se limita apenas a este. Muitos dos interesses mais importantes não encontram qualquer reconhecimento jurisdicional. $\mathrm{O}$ interesse também parece ser a fonte ou a medida dos principais conceitos jurídicos. Relaciona-se ao direito de estar em juízo, por exemplo. Daí sua onipresença. ${ }^{322}$

O interesse é, contudo, difícil de definir. É uma noção fundamental mas também negligenciada, que o direito cuida ora de qualificar (interesse legítimo, pessoal, etc.), ora de classificar (moral, patrimonial), mas nunca de definir. ${ }^{323}$ Até por isso, é comum que as noções de direito e interesse acabem sendo usadas, indiferentemente, uma pela outra ${ }^{324}$, como ocorre, aliás, no próprio processo coletivo brasileiro. "Proteiforme, a noção de interesse repugna a integração em qualquer categoria jurídica: ela resiste a todo esforço de sistematização", e extrai sua força justamente de sua capacidade de apelar ao senso comum $^{325}$

A flexibilidade do interesse é talvez sua marca mais notável de distinção em relação ao direito subjetivo, marcado sobretudo pela rigidez. ${ }^{326}$ Enquanto o último supõe titulares exclusivos ou ao menos bem identificados, o interesse se acomoda a relações mais difusas, mais indeterminadas, mais coletivas ou fluidas de titulação ("o interesse das gerações futuras, por exemplo). O objeto de incidência do interesse também é mais flexível. Ao invés de incidir sobre um bem perfeitamente determinado, como ocorre com o direito

\footnotetext{
${ }^{320}$ Idem, p. 9.

321 Idem, p. 10.

${ }^{322}$ Idem, ibidem.

323 Idem, p. 11.

324 Idem, ibidem.

325 Idem, ibidem.

${ }^{326}$ Idem, p. 12
} 
subjetivo, ele pode incidir sobre valores mais indefinidos, como a reputação, por exemplo, conforme nos adianta Ost. ${ }^{327}$

Acredito, por sinal, que essa nota de flexibilidade desponta como a principal característica a marcar a transição em direção ao interesse como categoria jurídica prioritária no mundo contemporâneo. Se é verdade que esse mundo acabou com as fronteiras entre o público e o privado, gerando formas de regulação jurídica mais fluidas, menos dotadas de coerção, multi-centradas, e se é verdade que a solução desses conflitos exige cada vez mais acordo e cada vez menos subsunção (o que parece ser a regra do novo contencioso apontado acima), então o interesse tem posição de destaque nesse mundo. Refiro, aqui, as palavras de Ost a respeito:

“[S]e compararmos as duas noções sob o ângulo das relações que elas estabelecem entre o titular e seu 'objeto', notaremos, uma vez mais, que à relativa rigidez de 'titulação/controle' (apropriação/manipulação) que caracteriza o direito subjetivo (...), corresponde a enorme variação na intensidade de vínculos de interesse que pode ir da simples conveniência ao desejo mais possessivo. De forma que o interesse, de intensidade variável, objetos múltiplos e titulares difusos, presta-se facilmente a todas as transições de plano do fato ao direito, do individual ao coletivo, do privado ao público, do ético ao político ou do econômico ao jurídico. Sob esse ângulo, o interesse aparece como o 'grande comunicador' da ordem jurídica. (...) De resto, o método próprio ao tratamento jurídico do interesse é bem aquele do cálculo, do sopesamento ou da balança. Sopesamento de interesses, balança da justiça." 328

Ainda segundo Ost, o interesse "induz um novo 'modo de produção do direito', segundo o modelo da computação, da negociação e do sopesamento, que contrasta com a adjudicação fechada ('por direito e sentença') de direitos subjetivos e lança esses últimos em uma lógica jurídica que lhes é, ao menos parcialmente, estrangeira”. Daí o caráter subversivo do interesse, mas ao mesmo tempo sua ligação intensa com a realidade. ${ }^{329}$ No mundo contemporâneo, a ponderação de interesses (a proporção da justiça distributiva aristotélica) parece querer substituir, por isso, a adjudicação estrita de direitos e responsabilidades (diria eu: a estrita igualdade das comutações). ${ }^{330}$

\footnotetext{
327 Idem, ibidem.

328 Idem, p. 13.

${ }^{329}$ Idem, ibidem. Note-se que a realidade tem se tornado cada vez mais objeto de preocupação da teoria jurídica. O marco inicial disso é o próprio realismo americano, que marca o nascimento de uma nova metodologia e de uma nova epistemologia jurídicas. V., a propósito, Jerome Frank, Law and the Modern MInd.

${ }^{330}$ François Ost, ob.cit., p. 17.
} 
Assim como as oposições entre conflitos bilaterais e policêntricos, ou entre as questões de justiça distributiva e comutativa, também as noções de direito e interesse representam, para Ost, "os dois pólos de um continuum entre os quais numerosas graduações podem ser encontradas". ${ }^{331}$ Mas o interesse, como modelo de posição de vantagem, exerce três funções específicas, correlacionadas a seu modo de ação. São elas (i) uma função criadora, permitindo a condução de novos atores e novas prerrogativas às "portas da cena jurídica", (ii) uma função limitadora, incidente sobre o exercício de direitos subjetivos e sobre a vontade individual, limitando-os (abuso de direito, interesse público, interesse geral, interesse coletivo, etc.) e (iii) uma função reguladora global, que se relaciona, fundamentalmente, com a emergência de um "direito social no início do século, que hoje se traduz por um modelo jurídico coerente, rival, por vezes vitorioso, do modelo de adjudicação de direitos. ${ }^{, 332}$

Que significa ter um direito subjetivo? Tradicionalmente, como herança de Savigny e da pandectística (Windscheid, cuja polêmica sobre a actio vai depois fundar a separação entre direito processual e direito material), significa "ter a habilidade de exercer um poder". ${ }^{333}$ Esse poder relaciona-se à "titulação e controle" sobre uma coisa determinada (conforme Jean Dabin). ${ }^{334}$ No direito subjetivo, "a vontade individual se reconhece num espaço de controle exclusivo". ${ }^{335}$ Por isso, a par da estrutura diferenciada que conhecem as posições de vantagem no campo administrativo, por exemplo, ele se consagra, em todo o direito privado, como a posição de vantagem típica do individualismo liberal. ${ }^{336}$

Essa sua característica gera efeitos sobre o esquema da adjudicação típica liberal. É conhecida a definição de Iherig, segundo a qual os direitos subjetivos são interesses que a lei quis proteger. Todavia, é preciso também perceber que a lei civil do liberalismo só intentou proteger interesses ligados à titulação e controle de coisas bem determinadas. Interesses de propriedade ou liberdade, aos quais outorgou proteção direta pela via do próprio interessado (o interesse juridicamente protegido):

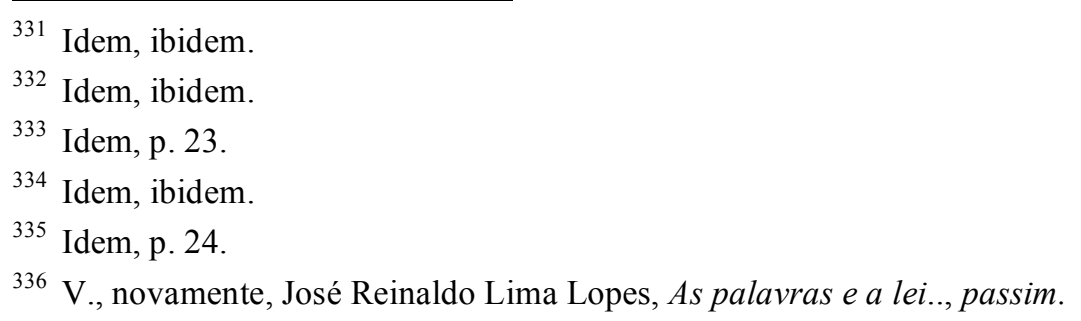


"Para falar de um interesse moldado em forma de direito subjetivo é preciso que a lei tenha confiado ao indivíduo, pela via da ação judicial, o cuidado de assegurar ele mesmo a proteção do seu interesse. O direito não é outra coisa que o interesse que protege a si mesmo. Nesse ponto de vista, a ação judicial se mostra a melhor indicação do direito subjetivo. Lá onde estão reunidas as condições clássicas da ação - um titular determinado, um objeto preciso, condições e efeitos mensuráveis e previsíveis - nos encontramos no campo do direito civil e dos interesses protegidos - protegidos na medida e em razão de 'possuírem aparência de corpos sólidos'. Por outro lado, no momento em que essas condições se diluem, que os interesses se tornam intangíveis, o poder do juiz civil cessa (não se pode de fato aprisionar o vento). Nessa hipótese, a administração toma o lugar do direito civil. ${ }^{\text {337 }}$

Essa estrutura diz respeito, naturalmente, a bens que possam ser apropriados individualmente, com exclusão de outros "direitos" de uso ou fruição. Não se enquadra, portanto, aos bens comuns, que são, como visto acima, o grande problema da justiça distributiva. Nesse contexto, e agora no plano do moderno processo coletivo, parece ficar clara a dificuldade de dar tratamento a esses bens (objeto dos "direitos" de solidariedade ou de terceira geração) através da base instrumental própria ao direito subjetivo. Iherig mesmo, sem ir, obviamente, tão adiante nessa constatação, o percebia, divisando uma espécie diferente de titulação nesse caso (de um lado, a dominação absoluta do direito individual, do outro, a comunhão indivisa e indivisível de fruição do direito comum). ${ }^{338}$ Citando Paul Roubier, Ost critica, no entanto, esse modelo que pretende assimilar todos os interesses protegidos pelo direito à categoria do direito subjetivo. ${ }^{339}$

Em tentativa final de conceituação, sua "análise gradualista", contraposta à "separação dicotômica" tradicional, Ost tenta enquadrar o interesse como o material que preenche uma espécie de esfera, cujo centro corresponde ao direito subjetivo:

\footnotetext{
"Na periferia, pode-se dizer que se movem os interesses marcados pelo descrédito: qualificados de ilícitos, sua satisfação é proibida sob pena de sanções civis e/ou penais. Mais ao centro, encontram-se os interesses puros e simples cuja perseguição é indiferente à ordem jurídica: sua satisfação não é nem proibida, nem recomendada. Próximos do núcleo duro da juridicidade, aparecem os interesses legítimos, cujo reconhecimento enseja uma certa proteção jurídica, essencialmente a proibição dirigida a terceiros de lhes causar prejuízo. Enfim, no coração, prevalecem os interesses consagrados sob a forma de direitos subjetivos que garantem a seu titular uma proteção jurídica máxima" ${ }^{340}$
}

\footnotetext{
${ }^{337}$ François Ost, Droit et Intérêt..., p. 25-26.

338 Idem, p. 26.

${ }^{339}$ Idem, p. 29 e ss.

${ }^{340}$ Idem, p. 36.
} 
Direito subjetivo e interesse são, por isso, categorias inseparáveis, pontos distintos numa mesma escala de grau. Mas sua distinção como modelos ideais gera percepções esclarecedoras. Uma delas, que tem toda a utilidade para a compreensão dos desafios gerados pelo novo contencioso de políticas sociais, é que, “[a]o passo em que os direitos subjetivos aparecem pré-constituídos antes de todo o litígio, os interesses somente tomam verdadeira consistência quando, por ocasião do litígio, suscita-se a regra ou a obrigação da qual eles são a contrapartida"341.

Essa característica do interesse legítimo como modelo ideal novamente remete ao que Ost chama de função criadora. "Pretensões difusas e não-coativas articulam-se juridicamente sob a forma de interesses reconhecidos, de pessoas e grupos até aqui mal determinados e julgados incapazes, os quais ora são chamados à cena jurídica como portadores de interesses"342. Nessa dinâmica, o interesse "será tanto mais facilmente acolhido quanto melhor ele puder moldar-se sob a forma familiar e reconfortante de direito subjetivo". ${ }^{343}$ O risco desse processo de criação é o risco de "conversão" visto por Füller e por Lima Lopes. ${ }^{344}$

A função criadora parece, segundo Ost, transformar a estrutura tradicional da adjudicação, alterando sua razão retrospectiva, por exemplo, exigindo um leque mais amplo de medidas de proteção, impondo uma "cadeia mais larga de intervenções." 345 Algo como se "a intervenção do árbitro, em nome do interesse, permitisse modificar as regras vigentes durante a partida, de forma que o jogo não se paute tanto pela lógica do permitido

\footnotetext{
341 Idem, p. 39.

342 Idem, p. 49.

343 Idem, p. 59.

${ }^{344} \mathrm{Na}$ justiça civil, o interesse "será tanto mais facilmente acolhido quanto melhor ele puder moldar-se sob a forma familiar e reconfortante de direito subjetivo". E o problema é que isso pode gerar dificuldades insolúveis de decisão, ao tentar-se identificar pontos de titulação e controle em relações que somente podem ser de comunhão, coordenação, divisão, acomodação. Daí, por exemplo, a eterna luta do processo coletivo brasileiro contra as categorias do direito disponível e indisponível, a sugerir que os interesses coletivos não comportam transação. Essa parece ser uma discussão equivocada, pois apenas se pode cogitar da disposição daquilo que é apropriado. Não há um ente coletivo fíctício que se tenha apropriado dos bens comuns. Sua divisão deve ser objeto de um processo de acordo coletivo que significa, basicamente, transação, negociação. O ponto é, portanto, o de verificar como se pode instrumentalizar institucionalmente essa barganha, sem deixar os interesses de nenhum possível interessado de fora. É também fazê-lo ordenadamente, no contexto da "explosão de litígios" que cerca vários desses conflitos sobre interesses. Como observa Ost, "nas diversas hipóteses de oposição de interesses reconhecidos, o recursos à arbitragem de terceiros se multiplicam ao ponto de, às vezes, se superporem". "É sem dúvida também uma característica do interesse, sendo menos estreitamente associado a um determinado titular que o direito subjetivo, fazer de seu objeto uma cascata de tutelas e controles (...)” Idem, p. 71.

345 Idem, p. 75.
} 
e do proibido mas pela lógica da oportunidade e da eqüidade ${ }^{, 346}$. A necessidade de testar soluções, vista por Füller em seu texto da década de 1950, e de recorrer a conhecimentos específicos, como diagnostica Horowitz, parece ser também decorrente da estrutura dos interesses, em cuja administração "o juiz é naturalmente chamado a se apoiar na colaboração de diversos peritos (assistentes sociais, psicólogos...) (...) os quais dedicam-se a propor e mesmo a testar as soluções que julgam mais apropriadas (...)."

\footnotetext{
"Esta também parece uma característica da lógica do interesse: enquanto o direito subjetivo, por seu traço de exclusividade, conduz a soluções simples e fechadas (...), o interesse, por outro lado, em vista de sua característica difusa (...), utiliza-se de soluções de compromisso. Poder-seia dizer que o direito opõe e impõe; o interesse compõe. Deste modo, as modalidades de composição são infinitamente diversificadas."
}

Essa função criadora ainda remete, segundo Ost, a um problema ligado ao tempo. "[O] interesse se inscreve na temporalidade do porvir" e, por isso, "participa igualmente de uma temporalidade aleatória que ao mesmo tempo desestabiliza situações pré-estabelecidas e assegura à sua regulamentação uma mutabilidade que lhe permite permanecer constantemente em consonância com as circunstâncias" Ainda segundo o autor, dois indícios confirmariam "a natureza precária do tempo do interesse: o fato de que ele é freqüentemente invocado em situações de urgência (...) e, por outro lado, o fato de que o regramento que lhe dispensamos traz muito freqüentemente a marca do provisório."349 Mais uma vez, a referência ao crescente uso de medidas liminares e provisórias, em substituição à composição definitiva de conflitos, no contexto do contencioso de cunho social no Brasil, parece ser necessária.

François Ost discorre também sobre a função limitadora dos interesses, mas essa discussão é de menor importância para os propósitos a que me proponho. Mais importante passa a ser a análise da função reguladora dos interesses, sobretudo naquilo que ela difere em relação ao direito subjetivo. ${ }^{350}$ Enquanto este remete a um modelo de "adjudicação",

\footnotetext{
${ }^{346}$ Idem, ibidem.

347 Idem, p. 76.

348 Idem, p. 77.

349 Idem, ibidem.

350 Idem, p. 155 e ss.
} 
aqueles invocam um modelo de "gestão": adjudicação de direitos subjetivos (o modelo do direito civil) e gestão de interesses (o modelo dos 'direitos sociais'). ${ }^{351}$

O novo modelo de gestão de interesses remeteria, segundo Ost, a transformações simultâneas nos modos de conhecimento, produção e aplicação do direito. ${ }^{352}$

Muda o modo de conhecimento do direito porque a ciência jurídica vê necessidade de aproximar-se de outras disciplinas e apoiar-se em conhecimentos distintos que a tornem mais colada à realidade concreta. No plano da produção do direito, há uma "referência cada vez mais sistemática aos interesses presentes". Naquele da aplicação, surge a figura do "juiz ator", engenheiro social, gestor de interesses que "em inúmeros setores do contencioso substitui o juiz árbitro". ${ }^{353}$ Surge, ainda, um modelo indutivo, mas que não é aquele do case law saxônico. É o do sopesamento de interesses, "onde as soluções legais são reagrupadas em função da preponderância dos interesses envolvidos," afastando-se da lógica binária do tudo ou nada e aproximando-se da lógica gradualista desses mesmos interesses. A igualdade, como vimos acima ao tratar dos problemas de distribuição, volta a ser uma igualdade das proporções. ${ }^{354}$

Os modelos da adjudicação de direitos e da gestão de interesses se contrapõem a partir de seis eixos distintos: o da epistemologia subjacente, o dos valores subjacentes, o da temporalidade, o da forma de regulação, o dos tipos de julgamento e o das prerrogativas. A partir das considerações feitas por Ost a respeito desses vários eixos, ${ }^{355}$ elaborei o Quadro n. 02, abaixo.

\footnotetext{
351 Idem, p. 158.

352 Idem, p. 170.

353 Idem, p. 171.

354 Idem, p. 172.

355 Idem, p. 175-184.
} 
(Quadro 02)

\begin{tabular}{|c|c|c|}
\hline \multicolumn{3}{|c|}{ "Modelos Jurídicos Concorrentes" de François Ost } \\
\hline $\begin{array}{c}\text { Marcas } \\
\text { Distintivas }\end{array}$ & $\begin{array}{c}\text { Modelo da } \\
\text { Adjudicação de direitos }\end{array}$ & $\begin{array}{c}\text { Modelo da } \\
\text { Gestão de interesses }\end{array}$ \\
\hline $\begin{array}{l}\text { Epistemologia } \\
\text { subjacente }\end{array}$ & $\begin{array}{l}\text { Distinção fato/direito, ser/dever ser } \\
\text { Modelo hierárquico/centralizado } \\
\text { Identidade, não contradição, terceiro } \\
\text { excluído (dicotomia certo/errado, } \\
\text { permitido/proibido) }\end{array}$ & $\begin{array}{l}\text { Fato e direito misturados } \\
\text { Autonomia apenas relativa entre direito, } \\
\text { economia, política, ética } \\
\text { Regras se acumulam de forma não } \\
\text { hierárquica } \\
\text { Lógica gradualista e relativista } \\
\text { (ponderação, provisoriedade, negociação } \\
\text { permanente) }\end{array}$ \\
\hline $\begin{array}{l}\text { Valores } \\
\text { subjacentes }\end{array}$ & Liberdade & $\begin{array}{l}\text { Solidariedade } \\
\text { O direito conduz a mudança social e } \\
\text { cultural para compor desigualdades e } \\
\text { restabelecer equilíbrios (discriminação } \\
\text { positiva) }\end{array}$ \\
\hline Temporalidade & $\begin{array}{l}\text { Tempo seguro, produtor de segurança } \\
\text { jurídica }\end{array}$ & $\begin{array}{l}\text { Tempo aleatório e precário, da } \\
\text { "instabilidade dinâmica, da proteção e } \\
\text { bens futuros e incertos }\end{array}$ \\
\hline $\begin{array}{l}\text { Forma de } \\
\text { regulação }\end{array}$ & LEI geral, abstrata, estável & $\begin{array}{l}\text { NORMA aberta, flexível, proteiforme, } \\
\text { subversiva. Norma adjetivadora e não } \\
\text { substantivadora. Princípio, Standard. }\end{array}$ \\
\hline $\begin{array}{l}\text { Tipos de } \\
\text { julgamento }\end{array}$ & $\begin{array}{l}\text { Julgamento dedutivo, de legalidade. } \\
\text { "Aplicação do direito ao fato" }\end{array}$ & $\begin{array}{l}\text { Julgamento de equidade de oportunidade. } \\
\text { Julgamento dentro da margem de } \\
\text { manobra da norma } \\
\text { Medida de "justa" composição }\end{array}$ \\
\hline Prerrogativas & $\begin{array}{l}\text { Direitos justapostos e hierarquizados } \\
\text { Prerrogativas estáveis, bem definidas } \\
\text { Rigorosa separação de territórios } \\
\text { Irreversibilidade de papéis }\end{array}$ & $\begin{array}{l}\text { Interesses que se diluem e se confundem } \\
\text { Prerrogativas mutáveis } \\
\text { Modelo da "conta-corrente" }\end{array}$ \\
\hline
\end{tabular}

Como podem as cortes de justiça, com seu arsenal instrumental clássico, darem conta do novo modelo? Essa é uma das questões adicionais colocadas pela análise da crítica instrumental à luz da emergência dos interesses como posições de vantagem típicas de uma sociedade contemporânea plural. Da exposição acima, deve ter ficado claro o papel estruturante que a categoria do direito subjetivo exerceu para a justiça na gênese e desenvolvimento do direito liberal. Exemplos adicionais em confirmação dessa tese poderiam ser dados abundantemente. $\mathrm{O}$ primeiro poderia até derivar de Chiovenda.

O primeiro item das Instituições de Chiovenda trata da lei e do direito subjetivo. ${ }^{356}$ Nos primeiros parágrafos do texto, Chiovenda aponta aqueles que, para ele, seriam os escopos fundamentais da regulação jurídica: promover a conservação dos sujeitos e dos

${ }^{356}$ Giuseppe Chiovenda, Instituições de Direito Processual Civil. 
bens que se lhes consideram próprios e regular a atribuição (apropriação) dos bens da vida aos diferentes sujeitos jurídicos. ${ }^{357}$ Para Chiovenda, o direito subjetivo consiste em uma vontade concreta da lei ${ }^{358}$, sendo que o escopo fundamental da jurisdição é, justamente, atuar as vontades concretas da lei, ou seja, garantir a efetividade dos direitos subjetivos. Em Chiovenda, esses direitos podem ser direitos a uma prestação ou direitos à modificação de estados jurídicos, esses últimos referidos pelo autor como direitos potestativos ou poderes, ${ }^{359}$ mas referem-se, todos, à categoria do direito subjetivo.

A célebre máxima de Chiovenda ainda explica bem essa associação entre processo e direito subjetivo: "o processo deve dar, quanto for possível praticamente, a quem tenha um direito, tudo aquilo e exatamente aquilo que ele tenha direito de conseguir. ",360

Outra remissão esclarecedora poderia dirigir-se ao próprio nascimento da idéia de autonomia do direito processual. Ele ocorre, sobretudo, a partir da tentativa de distinguir um direito subjetivo processual que, autorizando autonomamente o uso da ação judicial, não se confundisse com os direitos subjetivos materiais. ${ }^{361}$ A idéia de separação entre esses direitos subjetivos surge, como normalmente é registrado, a partir de uma outra investigação centrada na mesma categoria dos direitos subjetivos: a investigação quanto à existência, ou não, da noção de direitos subjetivos na tradição romana. ${ }^{362}$

Disso decorre, creio, que a estrutura mesma das regras processuais é moldada para cuidar de direitos. A legitimação é dada pela afirmação de titularidade deles. A transação é medida pela capacidade do sujeito de dispor desses direitos, assim como a própria regra atinente à adstrição da sentença ao quadro de soluções postuladas pelo autor é reflexo desse poder de disposição. A coisa julgada completa esse quadro estabilizando uma decisão que olhou para o passado, atuando a vontade representada pelo direito subjetivo. Quando inserimos interesses nesse jogo judicial, o sistema entra em perplexidade. Procura titulares e, quando não os encontra, pró́be a composição, que deveria ser, de outro modo, marca típica do novo modelo emergente. Sente que deve flexibilizar os princípios de adstrição mas não compreende exatamente por que. Entre o individual e o coletivo, tem

\footnotetext{
357 Idem, p. 17.

358 Idem, p. 18.

359 Idem, p. 26.

360 Idem, p. 67.

361 V. Francesco Carnelutti, Instituições de Processo Civil, Vol. 1, p. 366.

362 V. Bernard Windscheid e Theodor Muther, Polemica sobre la "actio".
} 
dificuldades de localizar a legitimação (interesse individual relacionado a bens coletivos, por exemplo). Resolve a questão para o futuro de forma provisória, por meio de liminares e medidas injuntivas, pois percebe, de alguma forma, que soluções mais rígidas são incompatíveis com a racionalidade dos novos conflitos.

\section{IV}

\section{A ESTRUTURA DA JUSTIÇA ENTRE A RETRIBUIÇÃo E O DIREITO SUBJETIVO: CRISE DO MODELO LIBERAL E EMERGÊNCIA DE UM NOVO MODELO}

Creio ter demonstrado, com as considerações acima, como as noções de comutação e direito subjetivo marcaram profundamente o desenho do espaço jurídico na tradição liberal. Em larga medida, os problemas sentidos hoje pela crítica instrumental endereçam questões ligadas, basicamente, aos desarranjos que acompanham a apreciação judicial de casos situados nos pólos opostos aos dessas categorias: casos que referem questões distributivas e envolvem interesses dispersos no corpo social, no mais das vezes antagônicos e contrastantes.

Não obstante essas conclusões, creio ter demonstrado, também, que essas críticas referem-se a um modelo específico de justiça, ao qual corresponde um modelo especifico de processo: a justiça e o processo forjados na tradição liberal. Se é verdade que têm sido operadas, no seio do direito liberal, as transformações que procurei apontar acima, torna-se razoável supor que essas alterações tenham provocado, de alguma forma, a remodelagem institucional dos órgãos judiciários, no sentido de tentarem adaptar seus instrumentos de trabalho aos novos tipos de conflito que lhes são endereçados.

Ressaltei, antes, que a demonstração desse fenômeno no direito nacional (independentemente de qualquer juízo quanto à efetividade dessas mudanças no sentido de ajustar a instituição a seus novos papéis) é um de meus objetivos com este trabalho. Antes de explorar esse ponto, contudo, parece fazer sentido referir os termos fundamentais de uma certa literatura que identificou, três décadas atrás, essa sorte de mudanças nas instituições judiciárias americanas, postas à prova com muito maior antecedência pelos mesmos desafios que as cortes brasileiras agora enfrentam. Os exemplos mais marcantes 
dessa literatura consistem nos textos publicados respectivamente em 1976 e 1979 por Abram Chayes $^{363}$ e Owen Fiss. ${ }^{364}$ Concentro-me, no final desta parte do trabalho, nos argumentos desenvolvidos pelos dois autores.

Chayes escreve já no contexto da reação operada pela Burger Court ao ativismo da corte presidida por Waren, mas procura descrever, em seu texto, aquilo que ele vê como a emergência de um novo modelo positivo de adjudicação. Chayes escreve antes da publicação póstuma do texto de Füller, mas claramente endereça parte de seu argumento como uma resposta às objeções de Füller:

\begin{abstract}
"Uma resposta ao modelo positivo de adjudicação poderia ser condená-lo como uma mistura confusa e intolerável de funções legislativas administrativas, executivas e judiciais, endereçada a problemas que por sua natureza são inapropriados à solução judicial. O Professor Lon Füller afirmou que quando essas funções são dadas ao judiciário elas se tornam parasitárias, no sentido de que somente poderão ser desempenhadas efetivamente com sacrifício da legitimidade e da força moral que as cortes desenvolveram através da performance de sua função inerente, a adjudicação, de acordo com sua concepção tradicional. Uma certa porção limitada desse parasitismo pode ser acomodada, mas uma porção maior que essa retira a própria legitimidade da qual ela depende, uma vez que as atividades não tradicionais do judiciário desafiam as condições que asseguram a força moral de suas decisões. De uma certa perspectiva, pode-se dizer que a Burger Court teria embarcado nesse programa de restauração das formas tradicionais de adjudicação. Suas decisões sobre interesse de agir, ações coletivas e honorários advocatícios em hipótese de advocacia do interesse público, entre outras, alcançam certa coerência nesse sentido. De outro lado, é difícil acreditar que a ação da Corte se move em razão de qualquer preocupação com a ortodoxia jurisprudencial. É possível suspeitar que sobre essa instância processual se esconde uma falta de simpatia com relação aos resultados substantivos alcançados, e com a idéia de serem as cortes locais veículos de reforma econômica e social. O desapreço da Corte por resultados reformistas é mal disfarçado - ou assim pensam os dissidentes o em dois casos recentes, Warth v. Selam, questionando regras de zoneamento nos subúrbios de Rochester, e Rizzo v. Goode, atacando a brutalidade policial na cidade da Filadélfica. Mas esses casos também podem ilustrar algumas das dificuldades desse retrocesso, se, como eu acredito ocorrer, o novo modelo de contencioso estiver integralmente relacionado ao caráter predominantemente público do direito nos sistemas jurídicos modernos. „365
\end{abstract}

Na construção de seu argumento, Chayes retoma novamente a idéia tradicional acerca do contencioso judicial, que o caracteriza como um mecanismo de solução de disputas entre partes privadas acerca de direitos privados. Assim, esse mecanismo seria, basicamente, (a) bipolar, (b) retrospectivo, (c) adstrito à interdependência existente entre

\footnotetext{
363 Abram Chayes, The role of the judge in public law litigation.

${ }^{364}$ Owen W. Fiss, The forms and limits of adjudication.

365 Abram Chayes, The role of the judge.., p. 1304-5.
} 
direitos e "remédios", ou seja, entre a extensão da violação dos direitos e a correspondente definição das formas de tutela jurisdicional, (d) referenciado como um "episódio autocontido", de impacto restrito às partes, e integralmente resolvido quando a decisão é proferida, e (e) controlado e iniciado pelas partes nele interessadas. ${ }^{366}$ Chayes via, contudo, que a característica mais marcante do contencioso mantido àquela época nas cortes federais era o fato de ele "não surgir de uma disputa entre partes privadas por direitos privados." Ao invés, o objeto desse contencioso consistia no questionamento de políticas legislativas ou constitucionais. ${ }^{367}$

Chayes via, portanto, na ação das cortes federais americanas, operar-se exatamente o tipo de transformação de que cogitei acima. Segundo ele, as principais características no novo modelo emergente de contencioso seriam a existência de uma estrutura amorfa e espalhada de partes, sujeita a mudanças ao longo do processo. Em oposição ao processo adversarial americano, no novo modelo a figura central passa a ser o juiz. Esse juiz passa a ser, aliás, o criador e gestor de um complexo contínuo de formas distintas de tutela jurisdicional, com efeitos espalhados de sorte a atingir pessoas que não participaram do contraditório judicial e que requerem envolvimento judiciário contínuo para sua administração e implementação. ${ }^{368}$

Chayes está se referindo, mais uma vez, ao nascimento da structural reform litigation no direito americano. Nela, o processo coletivo passa a envolver não os interesses individuais agrupados de inúmeras pessoas, mas verdadeiros interesses de grupo. $^{369}$. O foco deixa de ser a solução espontânea do conflito pelas partes, tradicional no sistema jurídico americano, e passa a ser a decisão judicial ${ }^{370}$, instrumentalizada por

\footnotetext{
366 Idem, p. 1282-3.

${ }^{367}$ Idem, p. 1284.

368 Idem, ibidem.

369 Idem, p. 1291.

${ }^{370}$ Idem, p. 1292. Note-se que, nesse ponto, o contencioso de direito público americano, das décadas de 60 e 70 , refere um modelo de atuação que ainda não é propriamente aquele da gestão de interesses de que fala Ost. É um modelo que confia ainda na capacidade da instituição judiciária de produzir a resposta correta, de resolver, independentemente, o conflito, de forma principiológica. A idéia de um juiz herói, que conhece o consenso moral da sociedade e é capaz de realizá-lo com justiça, desenvolvida por Dworkin, impera nesse modelo. Até por isso a barganha é vista com reservas (v., nesse sentido, Owen M. Fiss, Against Settlement; v., no entanto, quanto à negociação no momento de desenhar as providências destinadas a implementar a decisão judicial, Abram Chayes, ob. cit., p. 1299 (e nota 81). Com a decadência do modelo de Estado Social e a emergência de formas sociais mais fluidas, a crença nesse modelo de juiz diminui acentuadamente, ainda que isso não signifique apagamento do papel destacado das cortes de justiça. Significa, apenas, que o papel delas acaba se deslocando, ou deveria acabar se deslocando, para um papel mais mediador (v. François Ost, Tres Modelos de Juez..., cit.). No Brasil,
} 
injunctions, ou seja, por ordens complexas de abstenção, reorganização, imputação de condutas e acompanhamento dos resultados respectivos. ${ }^{371}$ Com as injunctions, também se desestrutura a ligação direta entre modalidades de direito e espécies de tutela jurisdicional, uma vez que os mecanismos de implementação das decisões já não decorrem naturalmente daquelas. ${ }^{372}$ Novas formas de gestão dos interesses de terceiros não presentes no processo mas afetados pela decisão eclodem e são, normalmente, centradas no papel gerencial e controlador do juiz.

No novo modelo que Chayes caracteriza, a ação das cortes em relação à descoberta dos fatos também muda radicalmente. A prova deixa de endereçar-se ao fato acontecido e passa a dirigir-se a possíveis estratégias destinadas a modificar, no futuro, o curso de certos acontecimentos. Trata-se assim de perceber o que irá, provavelmente, ocorer, caso seja tomada uma decisão em sentido tal ou qual. Circunstâncias de fato que somente podem ser aferidas por meio de palpites, ainda que esses palpites possam ser, pela virtude da instrução processual, "educated", ou seja, bem informados. ${ }^{373}$

Retomando aquela categorização feita a respeito das formas tradicionais de contencioso judicial, Chayes vê no modelo americano emergente as seguintes oito características: (a) o escopo da demanda não é determinado exogenamente mas delimitado em conjunto pela corte e pelas partes, (b) a estrutura de partes não é bilateral mas espalhada e amorfa, (c) a pesquisa dos fatos pertinentes à ação não é retrospectiva mas prospectiva, (d) a tutela judicial não se destina a remediar violações passadas e não se limita às partes imediatamente envolvidas no litígio: ela é desenhada ad hoc em termos flexíveis e amplos, tendo importantes conseqüências sobre pessoas ausentes no processo, (e) a implementação da decisão não é imposta mas negociada, (f) a sentença não termina o envolvimento judicial no assunto, que continua na fase de implementação da decisão, (g) o juiz não é passivo, mas assume um papel ativo de investigação dos fatos e organização do

como procuro mostrar adiante, a expansão do papel do judiciário ocorre tardiamente, em virtude da democratização também tardia. Ocorre, portanto, já no contexto de desagregação do modelo de Estado. Esse é um dilema adicional da experiência brasileira, que parece não ter encontrado ainda uma forma de institucionalização dos interesses sociais que não seja centralizadora, inteiramente confiante em figuras capazes de, por sua exclusiva vontade, resolverem os problemas sociais do país (o juiz, o promotor ou o presidente que, desta vez, conduzirá a nação a seu destino de crescimento e prosperidade).

${ }^{371}$ V. Owen M. Fiss, The Civil Rights Injuncton. V. tb. José Roberto dos Santos Bedaque, Tutela Cautelar... e Carlos Alberto de Salles, Execução Judicial...

${ }^{372}$ Idem, p. 1294.

373 Abram Chayes, The role of the judge..., p. 1296. 
procedimento, (h) o objeto das disputas não é uma disputa entre indivíduos sobre direitos privados, mas uma reclamação atinente à operação de uma política pública. ${ }^{374}$

Essa mudança no modo de ser das cortes federais americanas também foi sentida por Owen Fiss, e foi por ele explicada em termos de instrumentalidade do processo: o processo tornou-se dependente das condicionantes trazidas pela realidade material. ${ }^{375} \mathrm{O}$ contexto de contra-revolução marcado pela guinada conservadora da Suprema Corte americana no final da década de 1960 e na década de 1970, aliado ao distanciamento do tempo, permitiriam compreender melhor esse processo de mudança:

\begin{abstract}
"Em meio à era da Waren Court, as inovações processuais implícitas na reforma estrutural eram quase invisíveis. Cada passo era pequeno e incremental, cada um parecia inquestionavelmente correto. Agora isso é passado. Nós temos uma compreensão clara da década de 1960. A contrarevolução colocou foco nas mudanças no processo adjudicatório que ocorreram durante aquele período e, talvez mais importante que isso, as colocaram em questão. Nós fomos forçados, como talvez fosse mesmo necessário, a examinar a legitimidade dessas mudanças. É por isso que a academia está hoje repleta de discursos sobre o processo. É por isso que nós acreditamos estar em um momento histórico, um momento de mudança na história do processo - não porque estejamos no meio de uma revolução intelectual, mas porque estamos no meio de uma contrarevolução; não porque estejamos à beira de uma nova descoberta, mas porque as descobertas de uma era anterior estão agora em perigo., 376
\end{abstract}

Fiss descreve longamente o processo de instauração do contencioso relacionado à reforma institucional nos Estados Unidos, mostrando, também, como ele acabou por transformar algumas das características marcantes do processo judicial "tradicional". Assim, segundo seu diagnóstico, o modelo estrutural foi atacado, sobretudo, sob o fundamento de ter envolvido "um distanciamento em relação a uma dada forma ideal" de justiça. ${ }^{377}$ Em certo ponto de seu texto, então, Fiss questiona os termos desse modelo "ideal". 378

Ele identifica basicamente as mesmas transformações vistas por Chayes, e tenta responder às críticas feitas à afirmada incapacidade das cortes de justiça de lidar, adequadamente, como elas. Assim, por exemplo, tenta mostrar que o problema da

\footnotetext{
374 Idem, p. 1302.

375 Owen M. Fiss, The Forms of Justice, p. 3. V., a esse mesmo respeito, José Roberto dos Santos Bedaque, Direito e Processo..., passim.

376 Owen M. Fiss, The Forms aof Justice, p. 5.

${ }^{377}$ Idem, p. 17, grifo meu.

${ }^{378}$ Idem, p. 18 e ss.
} 
legitimidade dos grupos decorre apenas da relativa separação entre a figura dos titulares dispersos do interesse existente no grupo e daquele que age, no processo, como porta-voz desses interesses. Se pode haver dissenso quanto ao discurso trazido por diferentes portavozes, esse não seria um problema do processo judicial, mas um problema da própria realidade social: o dissenso não está na representação do interesse, mas na própria estruturação do interesse de grupo, às vezes disperso e parcialmente antagônico. ${ }^{379}$ Daí o papel destacado que passaria a assumir o juiz nesse tipo de contencioso. É ele, e não o conjunto dos porta-vozes, que passa a definir os termos de proteção do interesse litigado. É portanto um juiz ativo. ${ }^{380}$

Fiss identificava também a prevalência da injunction como mecanismo de tutela típico, ${ }^{381}$ o caráter prospectivo das soluções judiciais, ${ }^{382}$ o prosseguimento da função jurisdicional para além da prolação da sentença, ${ }^{383}$ a figura do processo judicial cada vez mais parecido com uma "assembléia municipal"384, marcada pelas intervenções de inúmeros amici curiae ${ }^{385}$.

É certo que Fiss não vê mudanças na função exercida pelas cortes (para ele, dar sentido aos valores constitucionais da nação). Contudo, ele vê e aponta claramente uma mudança na forma de atuação dessas cortes. ${ }^{386}$

Novamente, essa mudança poderia ser explicada, ainda que parcialmente, a partir das transformações ocorridas no século passado no seio no direito e das sociedades contemporâneas, as quais tentei, brevemente, explicitar acima. Minha tese, como já dito, é que uma ordem semelhante de mudanças atingiu, nas duas décadas passadas, também a estrutura da justiça brasileira.

Para tentar comprovar essa afirmação, e para tentar dar uma explicação possível às perplexidades sentidas, por exemplo, por Botelho de Mesquita, tento fazer, adiante, uma descrição daquilo que considero serem as características principais desse processo de

\footnotetext{
379 Idem, p. 21.

${ }^{380}$ Idem, p. 24. V. tb. José Roberto dos Santos Bedaque, Poderes Instrutórios do Juiz, passim.

381 Owen M. Fiss, ob. cit., p. 23.

382 Idem, ibidem.

383 Idem, p. 27.

384 Idem, p. 28.

385 Idem, p. 26.

386 Idem, p. 36.
} 
modificação institucional, à luz das condicionantes que procurei retratar nesta parte do trabalho. 


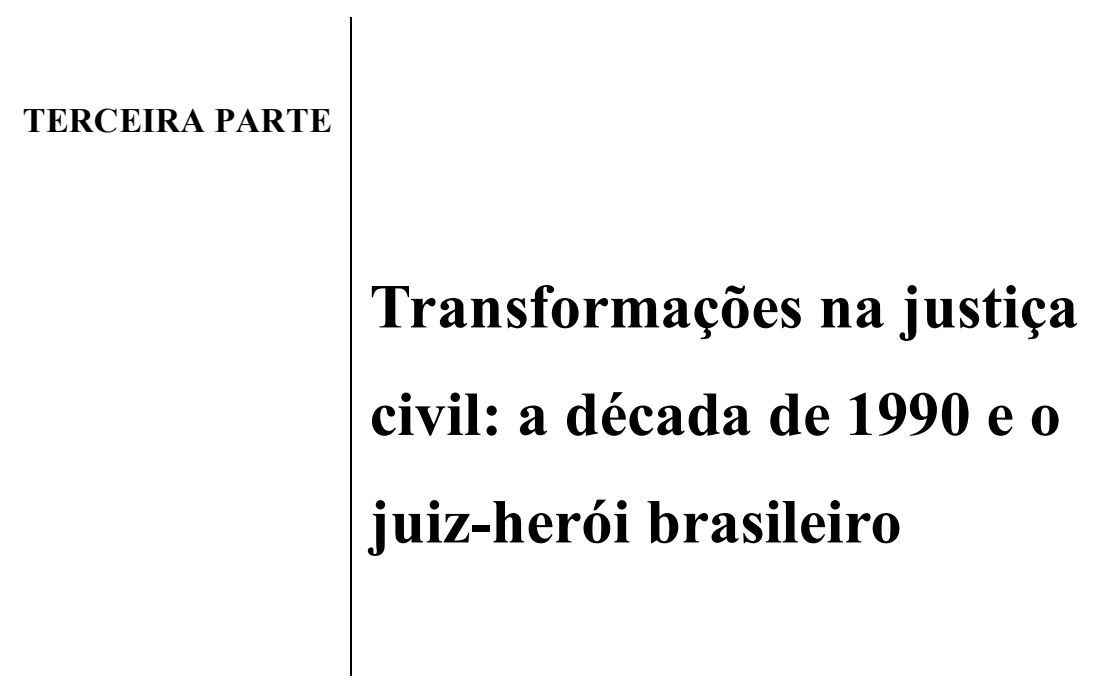

É certo que muito mudou no mundo desde que Lon Füller, Abram Chayes e Owen Fiss escreveram os textos referidos há pouco. Fiss mesmo o reconhece quando aponta, em um outro trabalho publicado já em 2003, que aquele juiz a que ele se referia em 1978, verdadeiro guardião da juridicidade, viria cada vez mais perdendo espaço a um outro tipo de magistrado, mais parecido com um gerenciador ou agenciador de acordos. No mesmo contexto, as intervenções judiciais sobre instituições públicas (presídios e escolas, sobretudo), que marcaram as décadas de 1950 e 1960 nos Estados Unidos, dão lugar, hoje, a ações envolvendo responsabilidade civil de massa, como modelos paradigmáticos de contencioso social. $^{387}$

Essas alterações parecem corresponder, em grande medida, ao próprio declínio do papel do Estado na contemporaneidade, ao qual correspondeu, parcialmente, um respectivo declínio nas funções de comando e controle exercidas pelo direito. O papel do Estado na contemporaneidade, assim, vem sendo pouco a pouco ocupado por ações endógenas do mercado ou do próprio corpo social, e essas mudanças dificilmente deixariam de atingir o contencioso judicial. A condição dos indivíduos é cada vez mais a de consumidores em uma sociedade de massas e cada vez menos a de cidadãos em uma polis centralizadora e organizadora das relações sociais. Por isso, por exemplo, a emergência da responsabilidade civil de massas e do contencioso coletivo de consumo como exemplos típicos de intervenção judicial de cunho social nos Estados Unidos. Por isso, também, a ênfase no papel mediador do direito, que se expressa pela crescente preferência por normas

${ }^{387}$ Owen M. Fiss e Judith Resnik, Adjudication and its alternatives (An introduction to procedure), p. v. 
substanciais de sentido aberto, acompanhadas de uma intensa preocupação em regular os procedimentos de tomada de decisão. ${ }^{388}$

Se o processo de judicialização da vida pública brasileira ocorre, sobretudo, a partir da abertura democrática, intensificando-se por efeito dos instrumentos de ação criados pela Constituição de 1988, isso significa que o transporte das considerações de Füller, Chayes e Fiss para o caso brasileiro precisa ser feito com cuidado, para que não se deixe de apreender a profunda alteração de contexto provocada pelas condicionantes político-sociais das décadas de 1980 e $1990^{389}$. Nosso processo, em relação ao análogo processo americano, é tardio, e essa circunstância não pode ser ignorada.

Nesse contexto, os diagnósticos feitos na parte anterior deste trabalho podem, no mínimo, servir de ponto de partida às reflexões atinentes ao processo brasileiro de judicialização da vida pública. Se ele passa aproximadamente pelas mesmas condicionantes, e é gerado por um conjunto de fatores institucionais que não são completamente dessemelhantes em relação ao exemplo americano, não seria surpreendente se algumas das mudanças observadas nos Estados Unidos nas décadas de 1960 e 1970 também se estivessem produzindo por aqui.

Como visto anteriormente, Abram Chayes identificou o modelo tradicional de contencioso civil a um conjunto de cinco características marcantes: (a) bipolaridade, (b) retrospecção, (c) interdependência entre direitos e formas de tutela, (d) auto-contenção (um episódio restrito às partes e integralmente resolvido pela sentença) e (e) controle exógeno (processo iniciado e controlado pelas partes nele interessadas). ${ }^{390}$

Em seu diagnóstico do novo modelo emergente, Chayes via (a) uma estrutura amorfa de partes, sujeita a mudanças ao longo do processo, (b) preocupações de caráter prospectivo, com o resultado futuro da ação judiciária e com os fatos daí decorrentes, (c) incremento no papel e poderes do juiz, (d) emergência de novas formas de tutela judicial,

\footnotetext{
${ }^{388}$ Essa transição relaciona-se diretamente à idéia de democracia deliberativa. V., a propósito, o conjunto de ensaios reunidos em James Bohman e William Rehg (ed.), Deliberative Democracy: Essays on Reason and Politics. Sobre o papel do direito na institucionalização desses procedimentos v. Junger Habermas, Direito e Democracia: entre Faticidade e Validade.

389 “O Judiciário, quer como ator coletivo, quer por meio da ação heróica e compadecida do juiz individual, abandona seu canto neutro e se identifica com a preservação de valores universais em uma sociedade que cada vez menos se reconhece no seu Estado, em seus partidos e no seu sistema de representação" (Cf. Luiz Wernneck Vianna et al., Corpo e Alma da Magistratura Brasileira, p. 39.

${ }^{390}$ V. Abram Chayes, The role of the judge in public law litigation, p. 1282-3.
} 
com efeitos sobre pessoas que não participaram do contraditório judicial e que requerem envolvimento judiciário contínuo para sua administração e implementação, e (e) acertamento conjunto (partes-juiz) do objeto dos litígios. ${ }^{391}$

Como tentarei demonstrar adiante, são encontráveis, nas transformações por que tem passado o processo judicial brasileiro, boa parte dessas características. Parece haver, portanto, uma resposta do sistema legal às novas exigências que lhe são impostas. Essa resposta não é de todo consciente e coerente, e não elimina, por certo, as várias irracionalidades e desajustes que decorrem, como visto, da submissão à máquina judicial de conflitos novos, com os quais ela não está acostumada a lidar (conflitos distributivos, relativos à gestão de interesses dispersos no corpo social). Mas essa resposta indica, claramente, uma evolução, que se pode explicar, também, pelas dinâmicas referidas até aqui.

No caso brasileiro, essa evolução (no sentido de transformação, de adaptação) é marcada por um percurso próprio, em que atuam como condicionantes específicas um contexto de explosão de litigiosidade e emperramento do órgão judiciário, aliado sobretudo a um dado institucional peculiar: o Ministério Público, tal como desenhado pela Constituição de 1988, independente da autoridade executiva, profundamente atuante na representação de certos interesses espalhados pelo corpo social e aparelhado institucionalmente para pleitear a proteção judicial sobre bens coletivos e indivisíveis.

Nesta parte final do trabalho, procuro mostrar como essas condicionantes agiram em conjunto com aquelas referidas anteriormente para desenhar um novo perfil de atuação da máquina judiciária, para atribuir um novo papel ao juiz brasileiro e, finalmente, para criar um novo aparato instrumental destinado a viabilizar o trabalho dos novos atores. Procuro identificar, também, problemas novos que se originaram deste arranjo institucional modificado, além das respostas quetêm sido forjadas pelo próprio sistema jurídico para dar conta desses problemas até então inéditos.

No item I, adiante, procuro fazer um rápido diagnóstico das mudanças por que passou o sistema judiciário ao longo da década de 1990 e desta década seguinte. Conforme procurarei evidenciar, essas mudanças provocaram transformações importantes na estrutura do processo judicial em matéria civil, as quais podem ser sentidas em ${ }^{391}$ Idem, p. 1291-9. 
basicamente três níveis de análise: o dos critérios de admissão em juízo, o do modo de ser do processo e o da estrutura das decisões. ${ }^{392}$ Cada um desses planos passa, então, a receber análise individualizada nos itens seguintes desta terceira parte.

No item II, tento mostrar como o modelo da gestão de interesses levou a importantes transformações na tutela de bens coletivos, sobretudo a partir da edição do Código de Defesa do Consumidor em 1990. Tento mostrar como a solução encontrada pelo direito nacional procurou endereçar as questões de titulação difusa referidas anteriormente, destacando o importante papel do Ministério Público nesse novo arranjo institucional. Pela importância dessa peculiar condicionante, ao Ministério Público é dedicado, também, todo o item III.

No item IV abordo as transformações ocorridas na estrutura do processo judicial, as quais têm flexibilizando a rigidez com que nosso direito vinha regrando, tradicionalmente, os procedimentos civis, ao mesmo tempo em que incrementam, consideravelmente, os poderes de gestão processual e de decisão dos juízes. Abordo, ainda, os problemas colocados pelo caráter prospectivo da prova no contexto dos novos conflitos sociais judicializados.

O item V é dedicado à "estrutura das decisões". Mostra como as formas provisórias e sumárias de tutela judicial têm crescido em importância e como a forma de tutela típica do contencioso social desloca-se cada vez mais da reparação por danos passados para a intervenção direta na realidade presente e redefinição de condutas e ações futuras. Esse mesmo item aborda, ainda, a necessidade sentida pelo sistema de outorgar flexibilidade aos comandos judiciais no contexto desse novo contencioso, preocupação que explica parcialmente tanto o movimento em direção às tutelas provisórias e de caráter injuntivo quanto a preocupação recente da literatura jurídica em flexibilizar a força preclusiva da coisa julgada.

O último item desta parte final trata de algumas respostas subseqüentes que vêm sendo geradas pelo contexto de mudança institucional acima referido. Essas respostas parecem identificar certa irracionalidade na ação judicial em matéria social, decorrente, sobretudo, do tratamento atomizado de questões distributivas e de amplo impacto coletivo.

\footnotetext{
392 A aglutinação das várias mudanças institucionais correspondentes nas duas primeiras categorias referidas acima é proposta por Cândido R. Dinamarco, em A instrumentalidade do processo.
} 
Por essa razão, tais respostas têm consistido, quase sempre, em tentativas de concentração das esferas decisórias, de concentração de poder nas cortes superiores e de incremento dos mecanismos de uniformização da jurisprudência e vinculação pelo precedente.

I

\section{TRANSFORMAÇÕES NA JUSTIÇA E NO PROCESSO: UMA IMAGEM DO CONTENCIOSO CIVIL BRASILEIRO EM "fin de siècle"}

Misturando "opulência e decadência", a justiça civil brasileira dos dias atuais lembra um pouco a Viena do final do século XIX: "sentindo profundamente os abalos da desintegração social e política"393, ela tenta reinventar a si mesma; vê-se, e é vista, com um misto de ansiedade, pessimismo, esperança e revolução.

Por um lado, está completamente sobrecarregada e tem imensa dificuldade em dar conta do volume de litígios com que é defrontada. É lenta ${ }^{394}$ e é ineficiente no desempenho de inúmeras atividades fundamentais como, por exemplo, a recuperação de créditos inadimplidos ${ }^{395}$. Vista como prestadora de serviços de solução de conflitos privados, ela é encarada com pessimismo e ansiedade, mostrando sua face decadente.

Por outro lado, essa mesma justiça engaja-se intensamente nas principais questões de política pública nacionais, vê seus instrumentos de ação aumentarem mais e mais e é enxergada como canal de representação de minorias e de grupos sociais excluídos do

${ }^{393}$ Cf. Carl E. Schorske, Viena Fin-de-Sciècle, São Paulo: UNICAMP/Companhia das Letras, 1990, p. 14

$39448,9 \%$ dos magistrados entrevistados no mais recente survey tendo por objeto essa categoria profissional consideravam a justiça "ruim" ou "muito ruim" no quesito agilidade. V. Maria Tereza Sadek (coord.), Pesquisa AMB 2005.

395 O diagnóstico corrente é que "o devedor inadimplente... encontra no sistema processual inúmeras formas de se furtar ao pagamento". De outro lado, a capacidade de constrição de bens por parte da justiça não teria, também, acompanhado a "evolução das relações econômicas", de modo a gerar-se uma "enorme distância entre as regras do Código de Processo Civil e a realidade da vida". (Cf. José Roberto dos Santos Bedaque, Direito e Processo, p. 125-6). Incapazes de exercer uma função de desestímulo sobre a inadimplência, os mecanismos judiciais são, então, substituídos por mecanismos informais de coerção, como, por exemplo, o Serviço de Proteção ao Crédito (v., a propósito, a manifestação de Armando Castelar Pinheiro no $1^{\text {o }}$ Seminário Nacional da "Reforma do Poder Judiciário, Desenvolvimento Econômico e Democracia", realizado em conjunto pela Escola de Direito da Fundação Getulio Vargas e pelo Jornal Valor Econômico no dia 06 de janeiro de 2002: Cadernos Direito GV n ${ }^{\mathrm{o}} 3$ - Seminários, p. 51, disponível em http://www.edesp.edu.br/files/artigos/Reforma\%20do\%20Judiciario.pdf. 
processo político formal. ${ }^{396}$ Em sua ação política e de mediação social, a justiça parece encerrar expectativas esperançosas e apontar para um potencial democrático revolucionário. ${ }^{397}$ Mostra, dessa feita, sua face de opulência, que precisa conviver com a face decadente e resolver as tensões daí decorrentes.

Como visto anteriormente ${ }^{398}$, por força de todo um conjunto de alterações institucionais, a justiça vê, no Brasil do pós-1988, aumentar incrivelmente seu papel. Isso acontece por uma série de fatores, quase todos eles ligados, direta ou indiretamente, à Constituição da Nova República.

Essa Constituição manteve o modelo brasileiro de jurisdição una e controle difuso de constitucionalidade, o que significa que atribuiu a qualquer juiz nacional a tarefa e a prerrogativa de analisar a legalidade de atos produzidos quer pelo legislativo, quer pelo executivo. Adicionalmente, o texto constitucional transformou em regra jurídica um conjunto amplo e por vezes contraditório de anseios sociais e políticos, consagrando ideais de liberdade individual e igualdade material, propriedade e redistribuição de renda, liberdade de empresa e dirigismo econômico. Outorgou à justiça a tarefa de implementar esse plano difuso de ação e ampliou significativamente os mecanismos de acesso que instrumentalizam esse ideal.

Assim é, por exemplo, que acabou eliminada no novo texto constitucional a possibilidade de escolha pelo Supremo Tribunal Federal dos casos que lhe são submetidos. Essa escolha, antes materializada pelo mecanismo da argüição de relevância ${ }^{399}$, foi considerada antidemocrática pelo legislador constituinte e expurgada do sistema constitucional. Além disso, foram outorgadas ao Ministério Público garantias de independência semelhantes às entregues ao próprio judiciário ${ }^{400}$, positivando-se sua competência para agir em proteção de qualquer interesse social, coletivo ou difuso. ${ }^{401}$

\footnotetext{
${ }^{396}$ V., nesse sentido: Luiz Werneck Vianna e Marcelo Burgos, Revolução processual do direito e democracia progressiva.

${ }^{397}$ Uma revolução sem revolução, ou uma revolução passiva desta vez virtuosa, como propõem Vianna, Carvalho, Cunha Melo e Burgos, referindo-se ao conceito desenhado por Gramsci (V. Luiz Wernneck Vianna et al., Corpo e Alma da Magistratura Brasileira, p. 33.

398 V., a propósito, o item v da primeira parte deste trabalho.

399 A argüição de relevância foi introduzida como requisito adicional de admissibilidade do recurso extraordinário em 1977, por meio da Emenda Constitucional n. 7, que mudou, para esse propósito, a redação dos parágrafos primeiro e terceiro do art. 119 da Constituição então vigente.

400 Constituição Federal, art. 127.

401 Constituição Federal, art. 129.
} 
Ampliou-se o rol de legitimados ao controle de constitucionalidade das leis, que ficou aberto, assim, também à sociedade civil, através dos partidos políticos, do Conselho Federal da Ordem dos Advogados do Brasil, das confederações sindicais ou das entidades de classe de âmbito nacional. ${ }^{402}$ Previram-se juizados especiais para pequenas causas cíveis, criminais e federais. ${ }^{403}$ Estabeleceu-se constitucionalmente a legitimidade processual das associações para representarem seus filiados em juízo. ${ }^{404}$ Constitucionalizaram-se inúmeros princípios processuais. ${ }^{405}$

À justiça, e aos órgãos que a cercam, a Constituição de 1988 dedicou diretamente 44 de seus 250 artigos, isso sem falar nas referências indiretas, espalhadas por todo o texto constitucional. ${ }^{406}$ Criaram-se também, por força da nova Carta, cinco novos tribunais de apelação em nível federal (os Tribunais Regionais Federais), além de um novo tribunal de sobreposição em matéria infra-constitucional (o Superior Tribunal de Justiça), destinado a absorver parte das competências antes atribuídas ao Supremo Tribunal Federal.

Portanto, a Constituição de 1988 está indissociavelmente na base do processo de judicialização da vida pública brasileira, tendo sido responsável, por isso, por desenhar boa parte da face opulenta que a justiça ostentaria a partir dos anos 1990. No entanto, como a virtude e o vício são qualidades dificilmente dissociáveis no arranjo institucional criado em 1988, sobretudo quando consideradas as restrições materiais que se impõem ao órgão judiciário (falta de recursos, pessoal, tecnologia, etc.), a mesma Constituição parece ter respondido, também, por boa parte da crise de eficiência que acompanhou a atuação do Judiciário a partir dessa mesma década. Isso pode ser ilustrado pelo Gráfico 02 abaixo, no qual está registrada a evolução anual do número de processos distribuídos ao STF.

Segundo dados do próprio Supremo Tribunal Federal, a média anual de processos distribuídos a essa corte era, na década de 1940, de 2.500. No final da década de 1950 esse número sobe para 7.000, mantendo-se estável entre 7.000 e 8.000 na década seguinte. $\mathrm{O}$ número pouco mais que dobra entre as décadas de 1970 e 1980. Portanto, em um espaço de

\footnotetext{
402 Constituição Federal, art. 103. No regime da Constituição anterior o único legitimado à ação era o Procurador Geral da República, que era nomeado pelo executivo e poderia, por ato do Presidente da República, ser demitido ad nutum. .

403 Constituição Federal, artigo 24, X.

404 Constituição Federal, artigo $5^{\circ}$, XXI.

405 Boa parte deles colacionados no artigo $5^{\circ}$, incisos LIV e seguintes, do texto respectivo.

406 Refiro-me especificamente aos artigos 92 a 135.
} 
50 anos, o volume anual de distribuições ao Supremo Tribunal Federal aumentou em aproximadamente oito vezes, i.e., cresceu a uma proporção média de 4,5\% ao ano.

Após a Constituição de 1988, contudo, em um espaço de apenas 16 anos (19892004), o volume anual de distribuições mais que quadruplica. Isso representou um aumento à proporção média de $10,5 \%$ ao ano. Se for tomado apenas o período compreendido entre 1997 e 2002, o aumento é de espantosos $470 \%$, ou 41,6\% ao ano.

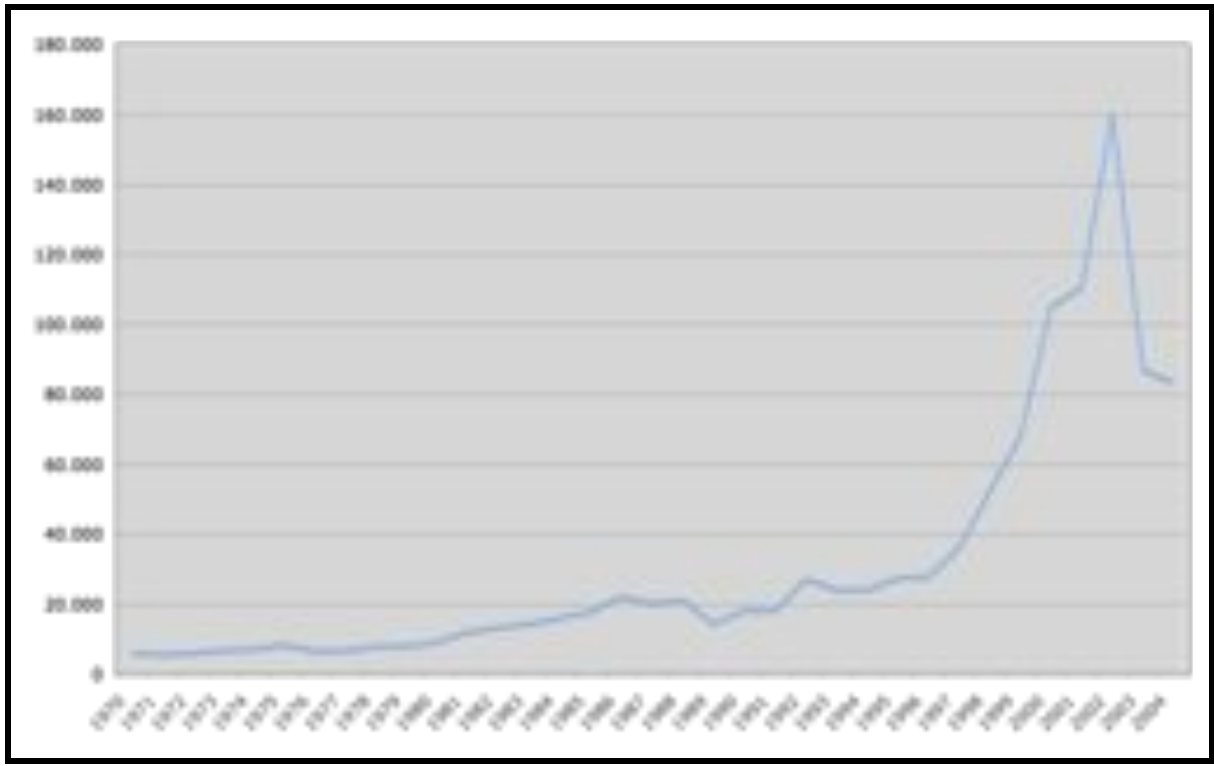

(Fonte: Supremo Tribunal Federal. Banco Nacional de Dados do Poder Judiciário (BNDPJ). Dados disponíveis em http://www.stf.gov.br/bndpj/stf/).

Se olharmos para os dados relativos ao Superior Tribunal de Justiça, criado pela Carta de 1988, a conclusão não discrepa. O volume de processos recebido por essa corte, entre sua criação e o ano de 2003, cresceu quase 34,5 vezes, o que significa um crescimento constante à razão média de $33 \%$ ao ano (v. Gráfico 03 ).

Esses dados de realidade têm informado recentes tentativas de constrição do acesso às cortes superiores e essa é, certamente, uma das reações de que falei na introdução a esta terceira parte do trabalho. No entanto, tais dados deixam claro o incremento extraordinário do papel desempenhado pelos juízes na sociedade brasileira a partir da virada para a década de 1990. Em outras palavras, o aumento impressionante na procura pelas cortes de justiça relaciona-se e determina o nascimento do juiz-herói brasileiro, que passa a defrontar-se com todo um leque de expectativas que até então vinham permanecendo 
contidas no corpo social, especialmente no que se refere às camadas intermediárias da população. $^{407}$

Parafraseando a famosa interpretação de Nonet e Selznik, a justiça brasileira caminhou, assim, no sentido de tornar-se uma instituição responsiva, retendo "a compreensão daquilo que é essencial à sua integridade, ao mesmo tempo em que dá conta das novas forças que agem em seu ambiente. Para fazê-lo, ergue-se apoiada nos modos pelos quais integridade e abertura sustentam uma à outra mesmo quando conflitam entre si. Ela percebe as pressões sociais como formas de conhecimento e oportunidades de autocorreção". 408

${ }^{407}$ A expressão juiz-herói é conhecida e de uso corrente na literatura, tendo sido usada no contexto brasileiro pelo Desembargador Celso Limongi, hoje presidente do Tribunal de Justiça do Estado de São Paulo, em seu discurso de posse no cargo de presidente da Associação Paulista dos Magistrados. Segundo o Desembargador Celso Limongi, "Como anota Marcelo Baumann Burgos, professor do Departamento de Sociologia e Política da PUC-Rio de Janeiro, a identidade do magistrado brasileiro, antes da Constituição de 1988, ficava "confortavelmente associada à figura do juiz-funcionário, cujo tipo ideal é o burocrata, que desempenha atividades politicamente neutras, de rotina e claramente demarcadas por um direito codificado, que o mantém afastado da realidade social. Mas, com a chamada revolução processual e com o constitucionalismo democrático (Cappelletti \& Garth, 1988), o juiz brasileiro é chamado a desempenhar novos papéis, mais afeitos à identidade do juiz-herói, "guardião dos direitos fundamentais e não simples operador da doutrina da certeza jurídica" (Vianna et al., 1997:37). Cf. Revista Fórum, da Associação dos Magistrados do Estado do Rio de Janeiro, n. 10, pág. 20 e 21. A Constituição armou o cidadão de instrumentos e mecanismos de intervenção e de participação na coisa pública, procedimentos jurídicopolíticos garantidores da defesa e da afirmação de direitos que a Lei Magna consagra. Assim, o Judiciário passa a revestir-se de acentuado caráter político, transformando-se em legislador negativo, quando acolhe ação direta de inconstitucionalidade ou desacolhe ação direta de constitucionalidade, e em legislador ativo, quando aprecia ação de inconstitucionalidade por omissão e o mandado de injunção. A ampliação da ação civil pública e o mandado de segurança coletivo, o mandado de injunção, a criação de juizados cíveis e criminais pelo País e a redefinição institucional por que passou o Ministério Público, como revitalizado defensor da sociedade e via de acesso à justiça, o habeas-corpus e o princípio da inafastabilidade da jurisdição (a lei não excluirá da apreciação do Poder Judiciário lesão ou ameaça a direito, art. $5^{\circ}$, inciso XXXV) fecham o arsenal de instrumentos destinado a fiscalizar a lisura dos atos da administração, do que resulta, como ensina Manoel Gonçalves Ferreira Filho, na justicialização da política e na politização da justiça (Revista Jurídica da Prefeitura do Município de São Paulo, n. 1, pág. 37). A importação do direito anglo-americano do devido processo legal na face substantiva (artigo $5^{\circ}$, inciso LIV, da Constituição), permitindo ao juiz discutir a razoabilidade das leis e mitigando o princípio da separação dos poderes, contribui, igualmente, para que o juiz não seja só a voz da lei, um ser inanimado proibido de pensar e de interpretar a lei, e acentua o caráter político da função jurisdicional, ainda segundo Manoel Gonçalves Ferreira Filho. E João Baptista Herkenhoff, em seu "Movimentos Sociais e Direito", também reconhece o poder político do Judiciário, não se limitando o juiz a ser apenas a boca da lei, caso em que muito pouca expressividade haveria no poder político do Judiciário (pág. 144).” A íntegra do discurso está disponível em http://www. apamagis.com.br/noticias/lerNoticia2.php?id_new=9. Esse juiz-herói não é outro senão o juiz-cidadão a que se refere Dinamarco, quando diz que "[o]s tempos exigem uma figura de juiz que vivencie os dramas sociais sobre os quais é chamado a atuar no processo" (Cândido R. Dinamarco, O futuro do processo civil brasileiro, p. 753).

${ }^{408}$ Nonet e Selznick, Law and Society in Transition, p. 77. Ainda segundo os autores, "The quest for responsive law has been a continuing preoccupation of modern legal theory. As Jerome Frank noted, a key purpose of the legal realists was to make law "more responsive to social needs." To this end, they urged a broadening of "the field of the legally relevant," so that legal reasoning could embrace knowledge 


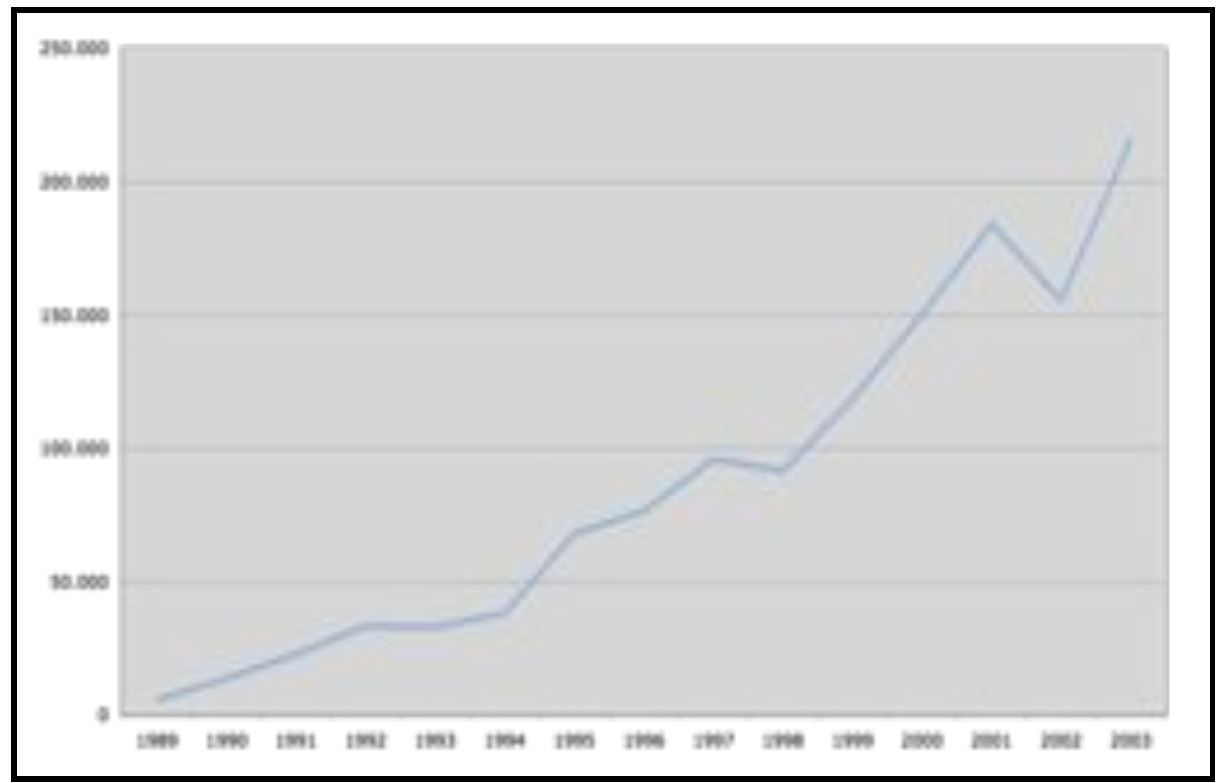

(Fonte: Supremo Tribunal Federal. Banco Nacional de Dados do Poder Judiciário (BNDPJ). Dados disponíveis em http://www.stf.gov.br/bndpj/tribunaissuperiores/STJ3A1.asp).

Como visto anteriormente, a partir dos instrumentos materiais fornecidos pela Constituição da Nova República (princípios abertos que consagram objetivos sociais parcialmente controversos, novos mecanismos de acesso à justiça, Ministério Público independente), o sistema jurídico cuidou de promover a reincorporação do problema político à esfera judicial, arrancando o órgão judiciário de sua posição de neutralidade $e$ passividade e colocando em questão certas interpretações consagradas do princípio da separação de poderes. ${ }^{409}$

Para uns, esta resposta às pressões sociais seria o ápice de uma radicalização republicana, "em que os cidadãos se relacionam 'não somente afirmando a própria vontade

of the social contexts and effects of official action. Like legal realism, sociological jurisprudence aimed at enabling legal institutions "to take more complete and intelligent account of the social facts upon which law must proceed and to which it is to be applied." Pound's theory of social interests was a more explicit effort to develop a model of responsive law. In this perspective good law should offer something more than procedural justice. It should be competent as well as fair; it should help define the public interest and be committed to the achievement of substantive justice. The realist and sociological tradition had one overriding theme: Open up the boundaries of legal knowledge. There was to be full appreciation of all that impinged on law and conditioned its effectiveness. From there it was but a step to a more expansive view of legal participation and the role of law. Legal institutions were to give up the insular safety of autonomous law and become more dynamic instruments of social ordering and social change. In that reconstruction activism, openness, and cognitive competence would combine as basic motifs." Idem, p. $73-4$.

409 Cf. Luiz Werneck Vianna et al., Corpo e Alma... (cit.), p. 45. Mesmo em dimensão histórica há quem conteste a efetiva prevalência desse princípio de neutralidade no direito liberal. V., v.g., Bruce Ackerman, We the People: Volume 1, Foundations. 
ou lutando por seus interesses predeterminados, mas também influenciando uns aos outros por meio do uso publicamente valorizado de argumentos, evidências e julgamentos fundamentados, e da persuasão que recruta argumentos para sua causa." "410 Para outros, este seria um caminhar em direção a formas de autoritarismo inaceitáveis no contexto democrático. ${ }^{411}$ Independentemente da interpretação que se escolha, o movimento é bem identificado, assim como suas origens. ${ }^{412}$

No plano infra-constitucional, uma certa abertura a essa ação responsiva já estava contida, de certo modo, na Lei da Ação Popular. ${ }^{413}$ Em 1985 a abertura se amplia, com a edição da Lei da Ação Civil Pública, originalmente prevista para viabilizar a tutela de interesses ligados ao meio ambiente, ao consumidor, a bens e direitos de valor artístico, estético, histórico, turístico e paisagístico. ${ }^{414}$ Em 1989, o espectro de utilização desse mecanismo judicial amplia-se ainda mais, para abarcar a tutela, pelo Ministério Público, dos interesses dos investidores no mercado mobiliário brasileiro (Lei n. 7.913, de 7 de dezembro ${ }^{415}$ ), bem como dos interesses relativos às pessoas portadoras de deficiências (Lei

${ }^{410}$ Idem, p. 42. Os autores estão citando, nesse ponto, Amy Gutmann, A Desarmonia da democracia. No trecho citado, Gutmman refere-se à noção já referida anteriormente de democracia deliberativa. $\mathrm{O}$ trecho completo é o seguinte: "Diversamente do populismo e do liberalismo negativo, a democracia deliberativa articula uma concepção persuasiva das pessoas como seres independentes, que refletem, julgam e decidem as questões com base em um amplo leque de considerações pertinentes disponíveis à sua consideração em uma sociedade em que todo adulto é tratado como uma pessoa autônoma sendo por isso assegurado a cada um o status político de cidadão igual. Junto com essa concepção vem um ideal de política em que as pessoas normalmente relacionam-se, não somente afirmando a própria vontade ou lutando por seus interesses predeterminados, mas também influenciando uns aos outros por meio do uso publicamente valorizado de argumentos, evidências e julgamentos fundamentados, e da persuasão que recruta argumentos para sua causa. Em uma democracia deliberativa, as pessoas decidem coletivamente sua própria vida política por meio da argumentação persuasiva. É claro que a persuasão é uma forma de poder; mas é a forma mais defensável de poder político porque é a mais consistente com o respeito à autonomia das pessoas, à capacidade que elas têm de autodeterminação”. Ob. cit., p. 20-21.

411 V. José Ignácio Botelho de Mesquita, As novas tendências do direito processual... (cit), passim.

${ }^{412}$ Uma interpretação interessante para arranjos institucionais do tipo escolhido pela Constituição de 1988 é dada por Tom Ginsburg. Para ele, "[t]hough nominally exercised on behalf of private citizens, constitutional judicial review does perform an insurance function for politicians who expect to lose power in future elections". Assim, "the extent and power of judicial review can be expected to increase relative to the degree of political uncertainty at the time of constitutional design". Ginsburg, sustentado em análise empírica, conclui que "independent and powerful courts are associated with situations of divided or deadlocked politics". Quem lembrar do ambiente de instabilidade e indefinição política que marcou a constituinte poderá sentir-se tentado a aceitar as conclusões de Ginsburg como uma explicação plausível para a atribuição de papéis tão importante à justiça. V., a propósito, Tom Ginsburg, Economic Analysis and the Design of Constitutional Courts.

${ }^{413}$ Lei n. 4.717, de 29 de junho de 1965.

${ }^{414}$ Lei n. 7.347, de 24 de julho de 1985.

${ }^{415}$ É preciso chamar a atenção para o escopo preventivo dessa atuação. Segundo o artigo primeiro da lei, as medidas judiciais requeridas ao seu amparo devem "evitar prejuízos". 
n. 7.853, de 24 de outubro). Mas é apenas na década de 1990, sob os influxos da nova Constituição, que esses instrumentos de ação ganham o corpo que têm hoje.

Logo no primeiro ano dessa década o Código de Defesa do Consumidor ${ }^{416}$ estabelece um verdadeiro sistema de administração judicial de interesses difusos e coletivos, atribuindo legitimidade ao Ministério Público e às associações para postular a defesa judicial de qualquer interesse enquadrável nessas categorias. Além disso, o Código estabelece que a proteção desses interesses não se dará apenas através de "ações de responsabilidade por danos," como sugeriam os artigos primeiro e terceiro da Lei da Ação Civil Pública, mas também por meio de "todas as espécies de ações capazes de propiciar sua adequada e efetiva tutela". ${ }^{417}$ Nessas ações o Código autorizou a concessão de tutela liminar provisória e permitiu ao juiz determinar quaisquer "providências que assegurem o resultado prático equivalente ao do adimplemento". 418

Também em 1990 é promulgado o Estatuto da Criança e do Adolescente ${ }^{419}$, que dedica um título inteiro ao acesso à justiça. O mesmo diploma legal estabelece as competências da "Justiça da Criança e do Adolescente" para apreciar questões envolvendo interesses difusos e coletivos, apreciar irregularidades em entidades de atendimento, autorizar a participação de crianças em espetáculos e seu ingresso em certos ambientes e exercer uma série enorme de outras atividades. Em vista das necessidades de conhecimento técnico envolvidas em todas essas atividades, o artigo 151 do Estatuto autorizou o Poder Judiciário a prever recursos em seu orçamento para manter uma equipe interprofissional de assessoria, cujas atribuições são, entre outras, as de "fornecer subsídios por escrito, mediante laudos, ou verbalmente, na audiência."

Em 1992 inicia-se um período de frenéticas alterações no Código de Processo Civil. Elas começam pela Lei n. 8.455, de 24 de agosto de 1992, que permite ao juiz, nas hipóteses de prova técnica, substituir a perícia formal pelo simples interrogatório do perito em audiência, quando entender que esse interrogatório possa bastar à apreensão dos dados técnicos necessários ao julgamento. A mesma lei permite a dispensa de prova pericial formal se as partes tiverem fornecido pareceres técnicos ou documentos elucidativos

\footnotetext{
${ }^{416}$ Lei n. 8.078, de 11 de setembro de 1990.

417 Idem, artigo 83.

418 Idem, art. 84.

${ }^{419}$ Lei n. 8.069, de 13 de julho de 1990.
} 
suficientes à informação do juízo sobre as variáveis técnicas da decisão. Em 1993, a Lei n. 8.718, de 14 de outubro, permite aos autores de demandas judiciais que promovam modificações ou adaptações em seus pedidos originalmente endereçados à justiça, desde que o façam antes da citação da parte contrária para resposta.

Em 1994 a Lei de Proteção e Defesa da Concorrência ${ }^{420}$ acrescenta mais uma hipótese de cabimento à ação civil pública: a proteção de interesses ligados à ordem econômica ou à livre concorrência. No mesmo ano, as Leis n. 8.950, 8.951, 8.952 e 8.953, todas de 13 de dezembro, alteram uma infinidade de dispositivos do Código de Processo Civil para, entre outras coisas, (i) autorizar ao juiz que antecipe, provisoriamente, o conteúdo da tutela requerida no processo, quando houver fundamento relevante e risco de dano à parte autora, ou propósito procrastinatório por parte do réu; (ii) enfatizar a conciliação; (iii) punir a deslealdade processual e (iv) dotar o juízo de mecanismos para a implementação de suas decisões semelhantes aos previstos pelo Código de Defesa do Consumidor e às injunctions norte-americanas ${ }^{421}$. Além disso, como resposta à utilização crescente de mecanismos provisórios e liminares de tutela, já sentida mesmo antes dessas alterações, modifica-se, em 1995, o regime recursal próprio à revisão dessas decisões de caráter provisório e sumário, alterando-se a sistemática do agravo de instrumento. ${ }^{422}$

Em 1999 são editadas, em reduzidíssimo espaço de tempo, as leis atinentes à argüição de descumprimento de preceito fundamental (Lei n. 9.882, de 3 de dezembro de 1999) e às ações diretas de inconstitucionalidade e constitucionalidade (Lei n. 9.868, de 10 de novembro de 1999). Além de outros aspectos, chamam a atenção nesses diplomas as seguintes disposições: (a) é franqueada à sociedade civil a oportunidade de participar nesses processos objetivos (sem partes em sentido substancial), o que redunda na adoção de mecanismos de admissão de amici curiae, inspirados em mecanismos semelhantes aos utilizados nos Estados Unidos, ${ }^{423}$ (b) são previstos mecanismos destinados a amplificar o debate e informar o Supremo Tribunal Federal acerca de matéria técnica importante para o julgamento, tais como audiências públicas, requisição de informações, elaboração de pareceres técnicos ou testemunho de pessoas "com experiência e autoridade na matéria,",424

\footnotetext{
${ }^{420}$ Lei n. 8.884 de 11 de junho de 1994.

${ }^{421}$ Esta última referência é, sobretudo, às modificações no artigo 461 do Código de Processo Civil.

${ }^{422}$ Lei n. 9.139, de 30 de novembro de 1995.

${ }^{423}$ Lei n. 9.868 , de 10 de novembro de 1999, art. 7, parágrafo $2^{\circ}$.

${ }^{424}$ Idem, art. 9, parágrafo primeiro.
} 
(c) "tendo em vista razões de segurança jurídica ou de excepcional interesse social", o Supremo Tribunal Federal é autorizado a "restringir os efeitos daquela declaração ou decidir que ela só tenha eficácia a partir de seu trânsito em julgado ou de outro momento que venha a ser fixado",425 e, finalmente, (d) a arguição de descumprimento de preceito fundamental é desenhada como processo objetivo destinado a eliminar controvérsia sobre a aplicação da Constituição e uniformizar sua interpretação, inclusive com a suspensão, liminar, de processos ou decisões judiciais que apresentem relação com a matéria objeto da argüição. $^{426}$

Já no novo século são publicadas novas leis modificadoras do Código de Processo Civil (Lei n. 10.352, de 26 de dezembro de 2001, Lei n. 10.358, de 27 de dezembro de 2001 e Lei n. 10.444, de 7 de maio de 2002). Essas leis: (a) reforçam o dever de lealdade, probidade e boa conduta das partes, acentuando o caráter público do processo e reduzindo seu aspecto de disputa privada, jogo entre adversários, (b) permitem a nomeação de vários peritos, nos casos de "perícias complexas", que envolvam mais de uma área do conhecimento, e (c) acentuam os poderes do juiz no que respeita a sua capacidade de impor medidas complexas de apoio ao cumprimento de suas decisões (imposição de multa por tempo de atraso, possibilidade de alteração de seu valor ou periodicidade a qualquer tempo, determinação de busca e apreensão, remoção de pessoas e coisas, desfazimento de obras e impedimento de atividade nociva, "se necessário com requisição de força policial").

Especificamente no que se refere aos propósitos deste trabalho, a mais recente alteração, até o fechamento deste texto, materializou-se através da Lei n. 11.232, de 22 dezembro de 2005, que acabou com o processo de execução de sentenças e retirou do texto legal a idéia da sentença como ato que termina o processo judicial. Na dicção do novo texto, o cumprimento das sentenças passa a ser, tanto nos casos de condenação quanto de

\footnotetext{
425 Idem, art. 27.

${ }^{426}$ Lei n. 9.882 , de 3 de dezembro de 1999 , art. $5^{\circ}$, parágrafo $3^{\circ}$. Como tentarei mostrar no último item dessa parte, essa já é uma reação aos problemas de irracionalidade que vão sendo sentidos na ação da justiça nessa década de 1990, irracionalidade decorrente da aplicação não uniforme, no plano individual, de regras distributivas, que se tornam assim não isonômicas e consequentemente injustas.
} 
injunção (a "tutela das obrigações de fazer ou não fazer"427), atividade subseqüente que requer, tanto quanto antes, intenso envolvimento judicial.

Não é preciso grande meditação, portanto, para encontrar nas alterações legislativas indicadas acima uma tendência clara de adaptação da justiça aos novos papéis exigidos daquele juiz-herói referido acima, exatamente na linha indicada por Chayes aproximadamente vinte anos antes de começarem todas essas reformas.

Por intermédio dessas alterações legislativas, enfim, (a) são criados mecanismos de participação capazes de permitir a veiculação em juízo de interesses dispersos no corpo social, viabilizando-se já alguma forma de participação que se encaixe nessa estrutura "amorfa" de partes (os amici curiae e as audiências públicas do controle concentrado de constitucionalidade, por exemplo), (b) são adaptadas as regras atinentes à prova técnica, com vistas a flexibilizá-la, a permitir o aconselhamento técnico do magistrado e a dar conta de situações complexas, que exijam conhecimentos multidisciplinares para sua solução, (c) são aumentados o papel e os poderes dos juízes, quer no que diz respeito à condução da prova e do procedimento, quer em relação à produção de decisões e "gestão" da implementação dessas mesmas decisões, (d) emergem novas formas de tutela judicial, de caráter mais prospectivo que retrospectivo, com efeitos sobre pessoas que não participaram do contraditório judicial e que requerem envolvimento judiciário contínuo para sua administração e implementação, (e) começam a viabilizar-se mecanismos que conduzirão, provavelmente, a um esquema mais flexível de delimitação do objeto dos litígios (v.g., a possibilidade de redefinição dos termos do pedido antes da citação do réu). Além disso, em conexão com aquilo que identificara Ost, o caráter volátil e dinâmico dos novos interesses litigados faz com que a tutela provisória, emergencial e prontamente modificável, torne-se, no novo contexto, o mecanismo de tutela por excelência.

Mais que ações previamente desenhadas de sorte a instrumentalizar um papel conscientemente querido para a justiça, essas alterações representaram, sobretudo, uma

\footnotetext{
${ }^{427}$ A bem da verdade, o termo injunção, apesar de representar estrangeirismo, designaria melhor esse conjunto de instrumentos que a expressão "tutela das obrigações de fazer e não fazer". Obrigação é o contraponto da faculdade na estrutura dos direito subjetivos. Corresponde ao aspecto de sujeição que se opõe ao poder de controle por parte daquele que tem direito à prestação. Pelas considerações feitas anteriormente, fica claro que, no mais das vezes em que esses mecanismos têm sido utilizados no contencioso de interesse público brasileiro, não há qualquer direito subjetivo em jogo, não há propriamente obrigações nem, tampouco, direitos à prestação, tal como classicamente considerados.
} 
resposta a necessidades previamente sentidas ${ }^{428}$. Em outras palavras, se é verdade que os instrumentos processuais acabaram alterando-se na linha antevista por Chayes, não é menos verdade que isso ocorreu porque nossos juízes pouco a pouco resolveram engajarse, claramente, em tarefas tão complexas como aquelas mesmas que marcaram a structural reform litigation americana. Passo a dar, abaixo, alguns exemplos disso.

No que se refere especificamente à estruturação e reestruturação de instituições públicas, essa atividade parece ter encontrado campo especialmente fértil no âmbito do Estatuto da Criança e do Adolescente. Essa tem sido uma das áreas de maior atuação do Ministério Público no Estado de São Paulo e essa atuação, freqüentemente, tem incluído ações judiciais destinadas a (i) obrigar diversos municípios a construírem abrigos para menores, (ii) redesenhar judicialmente as condições de trabalho em instituições ligadas aos objetivos do Estatuto, ou (iii) ordenar o redirecionamento de instalações públicas para fazer frente a necessidades distintas ligadas à proteção do menor.

Um exemplo do primeiro tipo de ação pode ser encontrado em duas demandas específicas ajuizadas pelo Ministério Público do Estado de São Paulo contra os Municípios de Barra do Turvo e Guarulhos, ambas submetidas à apreciação das Câmaras de Direito Público do Tribunal de Justiça do Estado de São Paulo. ${ }^{429}$ Em ambos os casos alegava-se omissão do poder público em seu dever de adotar medidas adequadas para garantir vagas a menores vitimizados ("fisicamente, moralmente, sexualmente, ou abandonados"), além de portadores de deficiências e usuários de entorpecentes, em abrigos públicos municipais, consoante seria exigido pelo sistema de proteção ao menor criado pelo Estatuto da Criança e do Adolescente.

Essas demandas são típicas de um contencioso no qual o Ministério Público de São Paulo engajou-se intensamente, não sem algum (talvez surpreendente) sucesso.

É bem verdade que a ação ajuizada contra o município de Barra do Turvo recebeu uma solução que se poderia chamar de "tradicional". O relator, Desembargador Aloísio de Toledo César, entendeu que o acolhimento do pedido significaria invasão indevida em

\footnotetext{
428 Até porque "o protagonismo do Judiciário... é menos o resultado desejado por este Poder, e mais um efeito inesperado da transição para a democracia..." (Cf. Luiz Wernneck Vianna et al., Corpo e Alma da Magistratura Brasileira, p. 12).

429 Respectivamente, tratam-se dos Agravos de Instrumento n. 399.864-5/7-00 e 303.687-5/1-00, distribuídos à segunda e quarta Câmaras de Direito Público desse tribunal.
} 
esfera de competência exclusiva (e discricionária) do poder executivo municipal, consistente na alocação de suas próprias verbas nos programas públicos que entendesse mais urgentes e relevantes. Segundo a ementa desse julgamento, “[n]ão pode o Judiciário substituir o administrador", já que sua "liberdade discricioniária (...) funda-se na consideração de que somente ele, em contato com a realidade, está em condições de aferir a oportunidade e conveniência de determinados atos".

Já a resposta dada pela justiça à ação proposta contra o Município de Guarulhos foi bem diversa.

Neste outro caso, o Desembargador Soares Lima entendeu que a decisão de primeiro grau, que havia concedido a ordem liminar requerida pelo Ministério Público, estava materialmente correta. Isso ocorreria porque, "[n]o tocante às condições mínimas necessárias para o cumprimento da legislação vigente, o Município é responsável pela adoção de política social, envolvendo crianças e adolescentes". Essa responsabilidade “decorre da lei", de sorte que, nesse contexto, não se pode "permitir a omissão administrativa, diante de situação irregular e gravíssima". O tribunal manteve a decisão de primeiro grau, mas aumentou o prazo concedido ao poder público para a construção dos abrigos, suprimindo, também, a imposição de multa em caso de descumprimento. ${ }^{430}$

O segundo tipo de decisão (reorganização de instituições) pode ser exemplificado por meio de nova iniciativa do Ministério Público do Estado de São Paulo, desta vez dirigida à "Guarda Mirim de Taubaté". Nesse caso, com fundamento no Estatuto da Criança e do Adolescente, o Ministério Público requereu o afastamento judicial definitivo dos então dirigentes da instituição, postulando ainda uma ordem judicial de alteração de seus estatutos, de sorte a impedir a permanência no cargo de direção por prazo indeterminado, viabilizar a ampliação do quadro societário, possibilitar eleições para presidente e demais componentes da assembléia geral, entre inúmeras outras providências. Essa ação foi ajuizada em fevereiro de 2000 perante a $2^{\text {a }}$ Vara Criminal e Seção da Infância e Juventude da Comarca de Taubaté. ${ }^{431}$

\footnotetext{
${ }^{430}$ A decisão pressupõe que o cumprimento ocorreria espontaneamente, ou então que se daria por uma das formas coordenadas que cada vez mais emergem no contexto desse contencioso social, conforme tentarei demonstrar na conclusão deste trabalho.

431 Representação n. 193/2000.
} 
Antes mesmo da citação dos representantes da Guarda Mirim, em caráter provisório e liminar, o juízo de primeiro grau acolheu o requerimento formulado pelo Ministério Público, destituindo a diretoria então vigente e ordenando a realização de eleições para preenchimento dos cargos, o que ocorreu em janeiro de 2001. Esse contencioso arrastou-se por longo período, com inúmeros desdobramentos processuais, mas fato é que a ordem liminar concedida em primeiro grau acabou por ser confirmada no Tribunal de Justiça do Estado de São Paulo.

O terceiro exemplo do tipo de intervenção a que referi acima remete a uma ação ajuizada pelo Ministério Público do Estado de São Paulo contra o Município de São Paulo, visando alterar a destinação de três albergues municipais, de sorte a utilizá-los também para o atendimento de menores carentes. Mais uma vez, o pedido, formulado em caráter de urgência e provisoriedade, foi atendido em primeiro e segundo graus de jurisdição, com base na "prioridade na proteção dos direitos da criança e do adolescente assegurada pela Constituição Federal (art. 227, caput) e pela legislação infraconstitucional (ECA, art. $4^{\circ}$ ), como dever da família, da sociedade e do Estado". 432

Essas não são intervenções judiciais isoladas. Já referi, antes, os casos de controle de tarifas públicas de telefonia por parte do Poder Judiciário ${ }^{433}$. Mencionei, também, a existência de inúmeras decisões ordenando o fornecimento gratuito de medicamentos à população doente. ${ }^{434}$ Outros exemplos poderiam ser retirados dos processos de questionamento judicial por que passaram quase todas as políticas de privatização implementadas nos últimos tempos. Poderiam ser referidas as decisões que têm ordenado a

432 Tribunal de Justiça do Estado de São Paulo, Apelação Cível no 37.609-0/5 - Comarca de São Paulo Relator Des. Luís de Macedo - j. 31/07/97.

${ }^{433}$ V. a propósito, o Conflito de Competência n. 39.590, decidido pelo Superior Tribunal de Justiça.

${ }^{434}$ V. a decisão, já referida anteriormente, proferida pelo Superior Tribunal de Justiça na Suspensão de Segurança n. 1.408. No âmbito da Sociedade Brasileira de Direito Público, tive a oportunidade de orientar um excelente trabalho desenvolvido sobre esse tema, levado a cabo pela aluna Mariana G. Barbosa como requisito parcial para conclusão de seu estágio na Escola de Formação (Mariana G. Barbosa, O Supremo Tribunal Federal e a Política de fornecimento de Medicamentos para Tratamento da AIDS/HIV). Esse trabalho analisa detidamente a posição do Supremo Tribunal Federal sobre o tema. Outro ótimo trabalho sobre esse assunto, abordando a jurisprudência do Tribunal de Justiça do Estado de São Paulo, foi elaborado no contexto do programa PET-CAPES por uma equipe de alunos de graduação da Faculdade de Direito da Universidade de São Paulo (Ana Carolina C. de Oliveira et al., O Judiciário e as Políticas Públicas de Saúde no Brasil: o Caso da Aids). Surpreendentemente, esse tipo de contencioso tem recepção muito mais fácil junto aos tribunais que aquele atinente à reestruturação de instituições de amparo ao menor, apesar de envolver, claramente, problemas distributivos muito mais graves. No caso, a receptividade decorre da facilidade com que as cortes de justiça conseguem converter tais problemas distributivos em "disputas sobre direitos", como advertia Füller. No contencioso envolvendo a reforma de instituições o caráter distributivo é dificilmente ignorável, apesar de a dimensão coletiva possibilitar, em tese, decisões judiciais muito mais coerentes e racionais. 
construção de rampas para deficientes físicos em prédios públicos ${ }^{435}$, ou a recente controvérsia judicial acerca da construção de um novo auditório no Parque do Ibirapuera, em São Paulo ${ }^{436}$. No âmbito do controle concentrado de constitucionalidade, a submissão ao Supremo Tribunal Federal de questões ligadas ao direito de aborto gerou um verdadeiro simulacro de assembléia pública nas dependências do tribunal, que incluiu inúmeros pedidos de intervenção como amicus curiae e passou pela determinação de realização de uma audiência pública, para oitiva de todos os interessados. ${ }^{437} 438$

Isso tudo muda, insisto, a face do contencioso judicial de feitio liberal, criado para resolver conflitos de justiça comutativa, entre partes individualizadas e opostas em um jogo de adversários, no qual se debatem apenas direitos subjetivos individuais. O exemplo mais claro disso deriva das próprias alterações legislativas referidas acima, que funcionam simultaneamente como respostas às necessidades sentidas pelo novo contencioso social e, também, como catalisadores dessas mesmas mudanças. Elas ao mesmo tempo condicionam e são explicadas pelas mudanças no contexto social e na dinâmica do direito brasileiro, como tentei argumentar anteriormente.

Não são alterações lineares ou sistemáticas, tampouco inserem-se em um plano mais amplo de reestruturação do papel dos tribunais. Seus resultados também não são necessariamente coerentes. Mas essas transformações indicam um processo de adaptação e reconstrução institucional que dificilmente poderá ser revertido.

\footnotetext{
${ }^{435}$ V., por exemplo, a seguinte decisão do Tribunal de Justiça do Estado de São Paulo: “Ação Civil Pública Estabelecimento público de ensino - Adaptação do prédio para acesso de deficientes físicos - Obrigação de fazer - Admissibilidade - Direito assegurado pela Constituição da República - Norma de aplicabilidade imediata - Ação procedente - Recursos não providos" (JTJ - 290/21).

${ }^{436}$ V. Tribunal de Justiça do Estado de São Paulo, Agravo Regimental n. 335.401-5/9-01.

437 Supremo Tribunal Federal, Argüição de Descumprimento de Preceito Fundamental n. 54.

438 Outros exemplos interessantes podem ser encontrados em Luiz Werneck Vianna e Marcelo Burgos. Revolução processual do direito e democracia progressiva, p. 478.
} 


\section{A TRANSFORMAÇÃo INTERPRETADA:}

\section{A ADMISSÃo EM JUÍZO ENTRE BILATERALIDADE E POLICENTRISMO}

O primeiro dos planos em que essas alterações operaram é o dos critérios de admissão de pessoas e causas em juízo. Esse é um tema que a dogmática jurídicoprocessual enfrenta debaixo do estudo das chamadas condições da ação, que durante bom tempo foram consideradas como condicionantes puramente processuais, relativas aos critérios de admissão em juízo. Sob o nomen iuris das "condições de ação" escondem-se, contudo, regras fundamentais ao funcionamento do sistema jurídico, consistentes naquelas que dizem quais são as pessoas autorizadas a provocar a autoridade judicial, quais são os conflitos de interesse passíveis de submissão a essa autoridade e que relação de proximidade aquelas pessoas devem ter com esses conflitos para poder levá-los ao órgão judiciário $^{439}$. Cruciais ao desenho do próprio sistema jurídico, essas não são, definitivamente, questões exclusivamente processuais. ${ }^{440}$

A regulação desses critérios de admissão em juízo demonstra uma das mais claras facetas do individualismo liberal reinante no direito brasileiro até o final da década de 1980. Seguindo fielmente essa tradição individualista, tornou-se comum associar, no direito nacional, a legitimidade para agir em juízo à titulação de uma posição de vantagem própria, individualizável e prontamente exigível. Uma posição que se parecesse, em outras palavras, com um direito subjetivo, com o "seu de cada um.",441

No sistema tradicional do Código de Processo Civil de 1973, a possibilidade de estar em juízo é fortemente associada à noção de titularidade ativa e passiva da ação ${ }^{442}$, ou

\footnotetext{
439 "What is at stake in the law of standing is, in part, the capacity of the legal order to inform itself of the range of issues and interests it affects" (Nonet e Selznick, Law and Society in Transition, p. 98.

${ }^{440}$ V., nesse sentido, Susana Henriques da Costa, Condições da Ação, p. 180 e José Roberto dos Santos Bedaque, Direito e Processo, p. 74.

441 "Somos todos vítimas de dogmas de fundo pandectista, como o da individualidade da tutela jurisdicional, que restringe a legitimidade para agir em juízo e o âmbito de eficácia dos julgamentos e com isso empobrece a tutela jurisdicional” (Cândido R. Dinamarco, O Futuro do Processo Civil Brasileiro, , p. 744). O direito subjetivo estrutura o seu de cada um, e a transição desse modo de proteção das posições de vantagem para um outro modo menos focado no indivíduo e mais ligado à sociedade é percebida pelo mesmo autor, nos seguintes termos: "[h]oje, importa menos dar cada um o que é seu, do que promover o bem de cada um através do bem comum da sociedade.” Idem, A Instrumentalidade do Processo, p. 279.

442 Enrico Tullio Leibman, Manuale.., p. 147.
} 
seja, de identidade entre aquele que invoca a proteção judicial e aquele que é titular (proprietário, manipulador e controlador) do direito subjetivo invocado. Nos termos do artigo $6^{\circ}$, "ninguém poderá pleitear, em nome próprio, direito alheio," o que implica reconhecer, na lei, uma delimitação precisa entre as esferas do "próprio" e do "alheio".

Como visto, essa delimitação é natural à categoria dos direitos, mas extremamente problemática na dos interesses, sobretudo daqueles dispersos no corpo social.

A grande guinada do direito brasileiro na década de 1990, no que diz respeito a esses critérios de admissão de causas e pessoas em juízo, consiste na abertura crescente à judicialização de interesses difusos. Essa é uma tendência que inicia, como visto, a partir da Lei da Ação Civil Pública, mas que se amplia bastante por meio das inovações legislativas subseqüentes.

A mais importante peça legislativa nesse contexto é o Código de Defesa do Consumidor, que fala em "interesses ou direitos" difusos, coletivos e individuais homogêneos. A lei não se engaja, portanto, na tentativa de distinguir as categorias dos direitos e interesses, mas reconhece, de toda forma, que a titulação difusa desses "entes" requer formas específicas de proteção judicial. Seguindo o modelo anteriormente adotado pela Lei da Ação Civil Pública, a solução adotada foi entregar a tutela desses "direitos ou interesses" a certos representantes institucionais (associações ou órgãos públicos), negando-se ao particular a possibilidade de ação em sua defesa. Apesar da terminologia dupla, a lei brasileira instituiu dessa forma as linhas fundamentais de nosso modelo da gestão de interesses, para usar a expressão empregada por Ost. No caso brasileiro, tratouse de um modelo de gestão "semi-pública", radicalmente oposto, nesse sentido, ao modelo americano de gestão privada de interesses difusos e coletivos.

Esse sistema semi-público parece ser, a um só tempo, a força e a fraqueza do modelo brasileiro. Para compreender a razão desse paradoxo, vale a pena fazer algumas notas de direito comparado. Por sinal, a própria importância da distinção direito $v$. interesse em relação às regras de admissão em juízo fica particularmente explícita se olharmos para o caso americano.

Até o início da década de 1970, as decisões da Suprema Corte dos Estados Unidos condicionavam a legitimação individual para o questionamento das decisões do poder 
público à demonstração de um direito afetado. Esse direito poderia tanto ser próprio (direito previamente reconhecido ao administrado pela lei) como poderia ser público, hipótese em que sua representação por meio de um indivíduo dependeria de autorização legal expressa. Essas noções têm, respectivamente, em Alexander Sprunt \& Sons, Inc. v. United States $^{443}$ e FCC v. Sanders Brothers ${ }^{444}$ seus leading cases.

Em Alexander Sprunt, a companhia autora buscava anular uma determinação da Interstate Commerce Commission que havia reestruturado as bases tarifárias relativas ao transporte ferroviário de algodão. A companhia autora não consistia em empresa operadora de transporte ferroviário, mas detinha um armazém localizado diretamente junto ao porto no Golfo do México. A estrutura tarifária anterior, tida pelo órgão regulador como discriminatória, dava a Alexander Sprunt uma vantagem competitiva sobre os demais armazéns localizados dentro do continente. Como essa vantagem foi perdida indiretamente por força da nova regulação, a empresa buscou sua anulação judicial, apontando uma série de irregularidades materiais e procedimentais que tornariam a regulação inválida.

Foi negada a Alexander Sprunt a condição de parte legitimamente interessada para levar o caso à Suprema Corte, uma vez que seu interesse seria meramente econômico, e que ela não teria sofrido qualquer "legal wrong”. Neste caso, decidiu-se que um mero interesse econômico, afetado por uma determinada decisão administrativa, não autorizaria alguém a buscar judicialmente sua desconstituição, pois do contrário esse alguém estaria agindo como fiscal abstrato da legalidade.

Em Sanders Brothers essa noção muda um bom tanto, pois a corte reconhece que, em certos casos, a lei pode, efetivamente, outorgar a sujeitos privados o status de fiscais abstratos da legalidade (i.e., a condição de "private attorney general”, ou, em tradução aproximada, de promotores de justiça privados $)^{445}$.

Neste caso, julgado em 1940, a Federal Communications Commission havia concedido uma licença de rádio a uma dada estação localizada na mesma região explorada pela rádio Sanders Brothers. A licença foi questionada judicialmente por esta última, por

${ }^{443} 281$ U.S. 249 (1930).

444309 U.S. 470 (1940)

${ }^{445} \mathrm{O}$ conceito não é utilizado pela corte neste caso, tendo sido cunhado três anos mais tarde por Jerome Frank, quando, no exercício do cargo de Juiz Federal, julgou Associated Industries of New York State, Inc. v. Ickes (134 F.2d 694 (2d Cir.1943). V. a respeito, Mashaw, Merril and Shane, Administrative Law, The American Public Law System, p. 955. 
uma série de argumentos, inclusive o de que o mercado local de propaganda não comportaria a existência de duas estações de rádio no mesmo local.

Sanders Brothers justificou seu interesse e legitimidade para agir a partir dos prejuízos que viria a sofrer em suas receitas caso a licença então concedida à concorrente entrasse em operação. Neste caso, a Suprema Corte decidiu que, ao invés do que havia ocorrido em Alexander Sprunt, a lei havia reconhecido à autora o poder de agir motivada por seu "mero" interesse econômico. Segundo a Corte, "o Congresso há de ter tido algum propósito ao editar a sessão 402(b)(2). Ele pode ter compreendido que alguém financeiramente atingido pela expedição de uma licença seria a única pessoa suficientemente interessada no assunto a ponto de trazer a atenção da corte de apelação para eventuais ilegalidades na ação da agência, decorrentes do ato de concessão da licença. É condizente com os poderes do Congresso conferir esse tipo de legitimação...". 446 Essa é uma resposta ao argumento central apresentado no caso pela Federal Communications Commission, segundo o qual o mero interesse econômico da parte não poderia servir de base para sua legitimação, já que, inexistentes direitos subjetivos ao monopólio do mercado, não haveria, também, remédio legal apto à proteção desse interesse. A construção utilizada pela corte neste caso gera a idéia de "public rights", que passa a ser utilizada até 1970.

Em 1970 é julgado o caso Assoc. of Data Processing Serv. Org., Inc v. Camp. ${ }^{447}$ Nesse julgamento, a Suprema Corte reconhece que o interesse jurídico necessário ao questionamento de uma dada ação estatal não precisa obrigatoriamente associar-se à proteção de um direito (um entitlement), seja público ou próprio ao autor, mas pode resolver-se apenas na proteção a um dado interesse econômico, ou de qualquer outra natureza, prejudicado pela ação estatal em questão, que esteja dentro da chamada "zona de interesses" que a lei supostamente deveria considerar ${ }^{448}$. Com isso, a análise das condições sob as quais um interesse meramente econômico pode transmudar-se em

\footnotetext{
${ }^{446}$ No original, "Congress had some purpose in enacting section 402(b)(2). It may have been of opinion that one likely to be financially injured by the issue of a license would be the only person having a sufficient interest to bring to the attention of the appellate court errors of law in the action of the Commission in granting the license. It is within the power of Congress to confer such standing to prosecute an appeal".

447397 U.S. 150 (1970).

${ }^{448}$ Cf. Mashall, Merril and Shane, ob. cit., p. 949-974. V. tb. Keneth C. Davis. The Liberalized Law of Standing.
} 
interesse jurídico, suficiente ao exercício da ação, torna-se problema fundamental no direito público americano, incorporando-se à noção de standing. ${ }^{449}$

Essa passagem da tutela de direitos para a tutela de interesses acompanha o reconhecimento e a absorção, por parte da esfera jurídica, de todo um conjunto de modificações na própria dinâmica social. No que tange aos casos referidos acima, acompanha, sobretudo, o crescimento da ação reguladora do Estado no contexto norteamericano. Contudo, no âmbito do direito e, sobretudo, após a guinada conservadora da Suprema Corte a partir do governo de Nixon, essa passagem para o modelo de gestão de interesses permanecerá marcada por um viés individualista. Isso fica claro no julgamento de Sierra Club v. Morton ${ }^{450}$ e, depois, em Lujan v. Defenders of Wildlife. ${ }^{451}$

O caso Sierra Club origina-se a partir de uma ação judicial promovida pela associação autora em face de Rogers Morton, Secretário do Interior dos Estados Unidos. O objetivo da ação é anular a decisão do Serviço Florestal americano no sentido de permitir a construção, pelo grupo Disney, de um imenso conjunto de hotéis, restaurantes, piscinas, estacionamentos e outros serviços de lazer em meio a uma área florestal inexplorada chamada Mineral King Valley, localizada junto ao Sequoia National Park, em Tulare, California. A associação autora justificou sua legitimidade para agir no fato de ter "especial interesse" na conservação e manutenção dos parques nacionais e áreas florestais. Obteve sucesso em primeiro grau, mas a corte de apelações acabou acolhendo a objeção, apresentada pelo Secretário Morton, quanto à viabilidade de ajuizamento da ação por uma organização do tipo representado pelo Sierra Club.

Segundo a corte de apelações, a associação não teria demonstrado que seus associados experimentariam qualquer prejuízo próprio com a construção do complexo em questão, "além de uma possível sensação de contrariedade ou descontentamento." A

449 A noção de standing no direito americano engloba o conjunto de preocupações que o direito brasileiro divide das categorias da legitimidade de parte e do interesse para agir. Engloba, portanto, questões ligadas a quem pode comparecer em juízo com aquelas relacionadas a $o$ que pode ser veiculado em juízo. Não por acaso, a noção de standing aplica-se sobretudo ao controle de atos da administração pública, em que impera a gestão de interesses. Quando estes estão em jogo, não há titulação individual das posições de vantagem, e a capacidade de ser parte é determinada pelo grau maior ou menor de proximidade que existe entre o interesse pessoal do agente e o grupo de interesses coletivos ou difusos que a lei quis proteger (igualmente, de forma mais ou menos intensa, conforme o caso). Nessas situações, não é possível separar as duas perguntas (quem e o que pode ir a juízo). A resposta de uma implica e condiciona, necessariamente, a resposta da outra.

450405 U.S. 727 (1972).

451504 U.S. 555 (1992) 
associação não teria demonstrado qualquer relacionamento direto entre seus associados e o parque, e a falta de um "interesse mais direto" implicaria falta de legitimidade para agir. Segundo a corte, não bastaria nestes casos demonstrar a mera possibilidade de ocorrência de dano a um dado interesse abstratamente protegido: seria preciso que o autor estivesse, ele mesmo, sujeito a sofrer, de forma significativa, o dano alegado. A Suprema Corte nega, em outras palavras, ao Sierra Club, a capacidade de representar interesses difusos e dispersos no corpo social, outorgando-lhe apenas a capacidade de representar os interesses pessoais de seus associados.

É bastante famoso o voto vencido de William O. Douglas nesse caso, sugerindo que, em hipóteses como essa de proteção a um parque nacional, seria melhor se a lei reconhecesse uma espécie ficta de legitimidade "ao próprio objeto inanimado que está prestes a ser destruído”. Segundo Douglas, “objetos inanimados são às vezes partes em uma ação judicial. Um navio tem personalidade jurídica própria, uma ficção achada útil para alguns propósitos de direito marítimo. A diocese $e^{452}$ - uma criação do direito eclesiástico - pode ser admitida como parte em um processo e imensas fortunas circulam nesses casos. As corporações ordinárias são uma "pessoa" para os propósitos do processo judicial, não importando se representativas de interesses econômicos, espirituais, estéticos ou de caridade."

Douglas sugere que o mesmo deveria ocorrer com vales, rios, lagos, estuários, árvores ou mesmo com o ar. Criada a ficção de sua personalidade jurídica, os interesses que gravitam em torno desses objetos ganhariam "porta-vozes” em juízo. Para Douglas, essa seria uma solução melhor que a administração desses bens pelo próprio poder público, porque o standard que guia a atuação do administrador nesses casos é demasiadamente frouxo, consistindo na idéia de interesse público, ela mesma uma ficção pior que aquela que ele está propondo. Segundo o juiz, “o 'interesse público’ tem tantas gradações

\footnotetext{
452 No original uma “corporation sole”. Essa entidade é definida no Black's Law Dictionary como um "unusual type of Corporation consisting of only one person whose successor becomes the corporation on his death or resignation." O paralelo, ainda que inexato, parece-me poder ser feito no direito brasileiro com a figura das dioceses, que tem sua personalidade jurídica reconhecida por um decreto de 1890 (Decreto Lei ${ }^{\circ}$ 119-A, de 07 de janeiro de 1890), ainda em vigor (cf. o Decreto n. 4.496/02), sendo representadas pelo bispo responsável por elas.
} 
diferentes de significado que chega a tornar-se algo quase desprovido de sentido no campo ambiental. ${ }^{, 453}$

Harry Blackmun também apresenta voto vencido neste caso e, elogiando a inventividade de William Douglas, propõe uma solução diferente: reconhecer às próprias associações legitimidade para agirem na persecução de seus interesses estatutários, independentemente da prova de dano específico a seus associados. Para Blackmun, essa atribuição de letigimidade ativa deveria ocorrer apenas nos casos de associações bem constituídas, que pudessem provar propósitos sinceros e que se dedicassem efetivamente a suas causas, para que a regra não se transformasse em uma caixa de pandora.

As propostas de Douglas e Blackmun não encontram eco na maioria da corte. Em Lujan v. Defenders of Wildlife a legitimação para a defesa de interesses difusos fica definitivamente associada à prova de um interesse particular, próprio e imediato do sujeito que os litiga.

A decisão proferida em Lujan é, de certo modo, a aplicação prática de postulados teóricos que já haviam sido anunciados antes por Antonin Scalia (juiz da corte responsável por relatar o caso) em seu artigo The doctrine of standing as an essential element of the separation of powers ${ }^{454} 455$. Polêmica, a decisão gerou intensa reação no meio acadêmico americano, por afirmar-se que reduzia, excessivamente, o campo de controle judicial sobre as políticas públicas. ${ }^{456}$

No estado em que está, o direito americano confere, hoje, plena proteção aos interesses não caracterizados como direitos subjetivos, mas condiciona sua tutela judicial à demonstração de um prejuízo imediato, diretamente sentido pelo autor. É por isso que

${ }^{453}$ Douglas segue, em boa parte, as idéias propostas no famosíssimo artigo de Christopher D. Stone (Should Trees Have Standing?).

45417 Suffolk U. L. Rev. 881 (1983).

455 Vale registrar que Antonin Scalia é tido como um dos juízes mais conservadores da Suprema Corte americana, sendo um dos defensores mais ferrenhos de uma interepretação rígida do principio da separação de poderes na Constituição americana. V., a propósito, Antonin Scalia, A Matter of Interpretation (with commentary by Amy Gutmann (ed.), Princeton: Princeton University, 1997, passim; trata-se de uma edição contendo o mais importante ensaio de Scalia sobre os limites da interpretação do direito, com comentários de Gordon Wood, Laurence Tribe, Mary Ann Glendom, Ronald Dworkin e uma resposta do autor).

${ }^{456}$ V., a propósito, o excelente e abrangente artigo de Cass R. Sunstein, What's standing after Lujan? Of citzen suits, ‘injuries' and Article III, 91 Mich. L. Rev. 163 (1992-1993). 
referi, antes, o caráter privado e individualista desse sistema de gestão de interesses difusos e coletivos.

Em relação ao sistema brasileiro sua deficiência é considerável, pois, em muitos casos, não será possível encontrar pessoas afetadas diretamente pela ação estatal que se disponham a questioná-la em juízo. Como foi referido no julgamento de Sierra Club, muitas vezes aqueles que têm um relacionamento mais direto com o bem ambiental ameaçado não têm sequer interesse em preservá-lo da destruição, pois vislumbram, em sua posição particular, possibilidades de ganho (donos de restaurantes localizados no parque esperarão aumentar suas receitas, proprietários de pequenos negócios tencionarão engajarse em acordos proveitosos com os grupos que pretendem explorar o lugar e assim por diante).

Esse caráter privado do sistema americano de gestão de interesses contrasta, como dito, com o sistema semi-público vigente no Brasil. Aqui, o problema da titulação difusa dessa sorte de interesses foi resolvido por meio de uma ficção bastante semelhante àquela proposta por Willian Douglas. Reconheceu-se que, se o interesse difuso não se esgota e individualiza em ninguém, passa a ser como que um "ser autônomo", que fala através de certos representantes escolhidos pela lei. Notadamente, órgãos públicos, o Ministério Público, ou associações fundadas há mais de ano.

$\mathrm{Na}$ análise de legitimação desses representantes faz-se exatamente a mesma investigação proposta por Blackmun: afere-se a relação de pertinência entre seus objetivos institucionais e o interesse perseguido em juízo. Havendo coincidência, é reconhecida a qualidade de "porta-voz" do interesse difuso em questão.

Essa solução brasileira tem grandes vantagens sobre a solução americana, mas tem também importantes desvantagens.

A principal vantagem consiste em viabilizar com muito maior facilidade a tutela de interesses altamente dispersos, como aqueles ligados ao meio ambiente, por exemplo, ou ao patrimônio cultural, artístico, histórico, etc. Como tentarei sistematizar abaixo, a lesão a esses bens específicos dificilmente redunda em prejuízo individual capaz de animar um sujeito privado a procurar proteção na justiça. Sem uma solução semi-pública, como a brasileira, essas lesões ficariam sem qualquer apreciação judicial. Não por outro motivo, a 
ação coletiva típica na experiência americana atual é aquela relativa à condenação por danos produzidos em massa, estimulada por mecanismos privados de expectativa de ganho (basicamente, os honorários de sucumbência) ao passo em que, na experiência brasileira, ela consiste em uma ação dirigida à proteção de interesses difusos e coletivos (v., nesse sentido, a Tabela 05, abaixo). Considerada a tendência à sub-representação desse tipo de interesse, o modelo brasileiro mostra-se ainda mais efetivo ao confiar sua tutela, em grande parte, à instituição do Ministério Público (v., a propósito, o item III, abaixo).

Mas há, como dito, importantes desvantagens. A mais severa consiste em ignorar que ao caráter difuso dos interesses incidentes sobre bens indivisíveis corresponde, também, um profundo dissenso quanto aos usos que devem ser dados a eles.

Na solução brasileira, os interesses difusos são tratados abstrata e fictamente como um conjunto coerente e unificado, um pouco como fora proposto por Douglas em sua idéia de atribuir personalidade jurídica aos objetos inanimados. É conferida uma unidade ficta aos interesses que gravitam em torno dos bens comuns, como se esses interesses não fossem aqueles mesmos titulados pelas pessoas que os usam, cada qual querendo dar-lhes um uso distinto.

É como se o interesse tivesse, tanto quanto o direito subjetivo, "um" titular específico. Pode parecer estranho dizer que nós lidamos com os interesses difusos como se fossem direitos subjetivos titulados por um ser abstrato, mas é justamente isso o que acontece quando consideramos que esses interesses são titulados pela "coletividade", assim entendida como um corpo uno e coerente. Dizer isso representa o mesmo que dizer, como queria Douglas, que são interesses pertencentes às árvores, às estátuas e aos prédios tombados.

Nossa noção unificadora do interesse difuso é tributária direta da idéia de interesse público, ressentindo-se, por isso, da mesma falsa unidade que a tradição do direito administrativo tentou emprestar a esta última categoria. Essa unidade foi denunciada por Douglas no trecho transcrito acima, tendo sido também, entre nós, contestada por Floriano de Azevedo Marques. ${ }^{457}$

457 Cf. Floriano Peixoto de Azevedo Marques Neto, Regulação Estatal e Interesses Públicos, São Paulo: Malheiros, 2002. 
Para exemplificar isso, basta pensar, novamente, no já citado exemplo da construção do novo auditório no Parque do Ibirapuera, levado há não muito tempo às barras dos tribunais paulistas. ${ }^{458}$

É evidente que se tratava de uma hipótese de conflito sobre interesses difusos. No entanto, seria um reducionismo inaceitável imaginar que, neste caso, estavam sendo contrapostos apenas dois interesses, ou dois feixes de interesses: de um lado, o interesse da municipalidade; de outro, $o$ interesse público ou $o$ interesse difuso na conservação do parque.

Muito ao revés, o caso era materializado por um conflito claramente policêntrico, em que uns queriam manter o parque virgem (aqueles que o usam para suas corridas matinais, por exemplo, ou simplesmente aqueles que moram nos arredores do parque e não querem ver aumentado o fluxo de veículos em sua vizinhança), outros queriam ver construído o auditório (porque usariam a nova estrutura de entretenimento, ou porque aufeririam vantagens econômicas com sua construção e exploração), enquanto outros não tinham, simplesmente, qualquer opinião a respeito.

Como parece ficar claro, tratar esses interesses dispersos e contraditórios como se fossem uma coisa só, uma só vontade capaz de materializar-se pela boca do Ministério Público ou de uma associação qualquer, não contribui para a adequada compreensão nem para a melhor solução do conflito, remetendo antes às dificuldades a que Füller se referia, quando afirmava que tudo o que é submetido à justiça acaba convertendo-se em uma disputa bilateral por direitos.

Em hipóteses nas quais a natureza distributiva do conflito fica mais evidente, em que torna-se mais clara a luta entre interesses múltiplos e contraditórios, o direito pouco a pouco parece produzir soluções capazes de acomodar as posições diversas em algum meio de participação mais complexo. Isso pode estar na base, por exemplo, dos mecanismos de amici curiae e audiência pública introduzidos em 1999 no âmbito do controle concentrado de constitucionalidade ${ }^{459}$. Talvez fosse possível usar esses mesmos mecanismos no âmbito do processo coletivo, mas ainda é sentido, nesse plano, o peso da tradição. Talvez essa seja, no futuro, uma das tendências evolutivas de nosso sistema.

\footnotetext{
${ }^{458}$ V. nota 436 , acima.

${ }^{459}$ Cf. a Lei n. 9.868, de 10 de novembro de 1999.
} 
Outra deficiência comparativa do sistema semi-público brasileiro é que, uma vez construída a dicotomia direito individual (tutela exclusiva pelo indivíduo) v. interesse difuso (tutela exclusiva pelo representante da coletividade), fica difícil lidar com os casos intermediários, em que alguém detém uma parcela tão intensa de interesse pessoal no bem coletivo que valeria a pena, por uma série de razões, atribuir-lhe legitimidade para litigá-lo em juízo.

Este é, novamente, um problema que deriva da dificuldade que o sistema jurídico de tradição liberal tem em lidar com a categoria do interesse juridicamente protegido.

Cândido Rangel Dinamarco explica que a doutrina jurídica brasileira nunca foi pródiga em especulações a respeito da distinção entre interesses legítimos e direitos subjetivos, muito provavelmente por ser o nosso sistema um sistema de jurisdição única ${ }^{460}$. Não obstante isso, a verdade é que boa porção das considerações normalmente lançadas pela dogmática processual acerca das condições de ação normalmente parte, francamente, de situações em que o interesse processual é dado pela defesa de um direito subjetivo, o que justifica, inclusive, afirmações correntes como a de que a legitimidade para a causa “corresponde à identidade das partes (sujeitos da relação processual) com os titulares da relação de direito material posta à apreciação do juiz"461. Como visto acima, essa identidade raramente se verifica na defesa de meros interesses, com o que o conceito fica vazio para explicar ou determinar as regras de legitimação aplicáveis nessas hipóteses ${ }^{462}$. E tais hipóteses são, hoje, cada vez mais freqüentes.

No campo então da jurisdição estatal, mais e mais se tem reconhecido individualmente a cada administrado o poder de questionar atos do poder público frente à jurisdição, inclusive em hipóteses nas quais nenhum direito subjetivo seu é afetado. Aqui, vê-se, como na experiência americana, a tendência de se reconhecer ao particular a

460 Fundamentos do Processo Civil Moderno, p. 864.

461 Ovídio A. Baptista da Silva e Fábio Luiz Gomes, Teoria Geral do Processo, p. 126.

462 Como manifesta Liebman, "bisogna a questo proposito distinguere appunto tra diritti ed interessi. La situazione soggettiva che trova nella legge la protezione più piena è quella del diritto soggettivo, che ricorre quando l'interesse del soggetto è riconosciuto come esclusivamente proprio del suo titolare ed è come tale direttamente garantito dalla norma giuridica. Si ha invece un interesse legittimo quando l'interesse di un soggetto trova protezione nella legge solo indirettamente, perché si trova a coincidere con un interesse pubblico che la legge intende tutelare nel disciplinare l'esercizio del potere dell'organo amministrativo; in questo caso l'osservanza da parte dell'organo della norma che tutela l'interesse pubblico soddisfa in pari tempo di riflesso 1'interesse del singolo soggetto, così come l'inosservanza della norma lede, insieme con 1'interesse pubblico, anche l'interesse del singolo" (Manuale, p. 20-1). 
condição de fiscal da juridicidade no desempenho da Administração Pública ${ }^{463}$, com o conseqüente poder de voltar-se contra atos ilegais sempre que um dado interesse seu possa, de uma ou outra maneira, fazer-se "coincidente com o interesse geral na preservação da legalidade".

Novamente segundo Dinamarco, "restariam indesejáveis resíduos não jurisdicionalizáves de conflitos" caso não fosse reconhecida legitimidade àquele que é privado, pela administração, de alguma utilidade, não traduzida contudo em um direito subjetivo seu. ${ }^{464}$ Todavia, na tutela de meros interesses, a grande dificuldade que se verifica é determinar em que medida essa privação poderia autorizar o exercício do direito de ação para desconstituir, por exemplo, relação jurídica existente inter alios.

A dificuldade se mostra ainda mais premente na medida em que, como visto, as evoluções havidas no direito público fazem cada vez mais com que a idéia mesma de um interesse público único, com o qual o interesse do particular pudesse identificar-se, perca muito de sua força conceitual, ao passo em que se compreende a administração pública, cada vez mais, não como vassala e intérprete autoritária de um suposto interesse público único e de caracterização sempre fugidia, mas sim como verdadeira intermediária, como verdadeira mediadora de uma gama variada de interesses públicos, espalhados pelo corpo social. $^{465}$

$\mathrm{Na}$ experiência européia, esse é um tema correntemente tratado pelas justiças administrativas, nos países em que, como na Itália, vigora a dualidade de jurisdição. Nestes, jurisdicionalizam-se na justiça civil unicamente os direitos subjetivos, ficando a tutela de interesses legítimos frente à administração pública a cargo das cortes administrativas, cujos estatutos processuais são em geral distintos ${ }^{466}$. É o que ocorre

463 "Human imagination has designed innumerable methods of providing public and collective interests with access to justice. One important means is to entrust representation in court of such interests to private individuals" (Mauro Cappelletti, Public Interest Parties and the Active Role of the Judge in Civil Litigation, p. 101). Na mesma obra, aliás, Cappelletti anota a posição de Vigoriti, segundo a qual essa forma de proteção do interesse público resultaria substancialmente mais eficiente que a própria figura do Ministério Público na Itália, que teria sido privada de qualquer relevância prática e " whose ambiguities make it unable to serve its intended role" (idem, ibidem). Sobre essa questão irei retornar no item III, adiante.

464 Fundamentos, p. 864.

${ }^{465}$ Cf. Floriano Peixoto de Azevedo Marques Neto, Regulação Estatal e Interesses Públicos, p. 158, citando nesse sentido a posição de Odete Medauar.

466 Sobre a evolução histórica, na Itália, do sistema de tutela dos cidadãos em face da Administração Pública, ver Vittorio Denti, La giustizia civile (lezioni introduttive), p. 98-101, em que se registram inclusive as 
também em Portugal, por exemplo. ${ }^{467}$ No campo dos interesses, diz a jurisprudência portuguesa, não se afere o direito de estar em juízo por critérios de titulação, mas sim por uma medida de grau: busca-se aferir a intensidade do interesse individual, busca-se saber o quanto ele é direto e imediato em relação à política pública ou ao "interesse difuso" que se quer discutir. ${ }^{468}$ Esse é um caminho que o direito brasileiro parece estar ainda descobrindo, mas que já dá sinais de existência em textos como o da Lei de Proteção e Defesa da Concorrência (Lei n. 8.884, de 11 de junho de 1994). ${ }^{469}$

De toda forma, em que pesem esses problemas específicos, parece difícil deixar de reconhecer à solução encontrada pela lei brasileira importantes vantagens, ao menos no plano dos interesses excessivamente dispersos, em cujo âmbito a lei nacional proporciona graus de controle judicial bem mais elevados que as soluções americanas. ${ }^{470}$ Isso acontece não apenas pelo caráter semi-público, referido acima, mas também pela aposta institucional, feita pela Carta de 1988, na representação desses interesses por parte de um órgão público autônomo em relação ao Poder Executivo (o Ministério Público). Sobre esse tema são feitas considerações específicas no item III, abaixo.

tentativas na última Constituinte de abolir o sistema de jurisdição dupla, bem como a tendência, atual, de aproximação das duas "justiças”.

${ }^{467}$ V., por exemplo, Marcello Caetano, Sobre o problema da legitimidade de partes no contencioso administrativo português.

${ }^{468}$ Idem, p. 11 (com detidas considerações sobre a evolução do assunto na jurisprudência administrativa portuguesa e também francesa, até aquele momento).

${ }^{469}$ O artigo 29 dessa lei dispõe o seguinte: “Art. 29. Os prejudicados, por si ou pelos legitimados do art. 82 da Lei $\mathrm{n}^{\circ}$ 8.078, de 11 de setembro de 1990, poderão ingressar em juízo para, em defesa de seus interesses individuais ou individuais homogêneos, obter a cessação de práticas que constituam infração da ordem econômica, bem como o recebimento de indenização por perdas e danos sofridos, independentemente do processo administrativo, que não será suspenso em virtude do ajuizamento de ação." Trata-se, portanto, de uma hipótese em que o prejudicado, amparado na justificativa de seu dano pessoal, age como fiscal abstrato da legalidade, protegendo, indiretamente, "os" interesses do "mercado".

470 Note-se que está em fase de elaboração um Anteprojeto de Código Brasileiro de Processos Coletivos, cujo texto está a cargo de Ada Pellegrini Grinover. Se aprovado, o projeto de lei tende a suprimir boa parte das deficiências indicadas acima, inclusive concedendo legitimação individual para a tutela de interesses no plano coletivo. Outras inovações presentes nesse Anteprojeto em fase de elaboração serão comentadas adiante. 


\title{
III
}

\section{O MINISTÉRIO PÚBLICO: NOVO ATOR SOCIAL}

O problema da sub-representação é central no âmbito da proteção jurídica dos bens coletivos. Por razões práticas, ainda que sejam superados todos os obstáculos legais à postulação judicial dos interesses relativos à sua preservação, esses interesses tendem, mesmo assim, a não ser jurisdicionalizados. A bem da verdade, o mesmo ocorre também no plano dos bens individualmente apropriados, sempre que a lesão a esses bens for percebida por seus titulares como insignificante ou, ao menos, reduzida demais a ponto de justificar os custos de um litígio. A caracterização dessas hipóteses é dada por Cappelletti, para quem:

\begin{abstract}
"a complexidade da sociedade moderna, com intricado desenvolvimento das relações econômicas, dá lugar a situações nas quais determinadas atividades podem trazer prejuízos aos interesses de um grande número de pessoas, fazendo surgir problemas desconhecidos às lides meramente individuais. Falsas informações divulgadas de uma sociedade por ações podem prejudicar a todos os adquirentes dos títulos acionários; atividade monopolística ou de concorrência desleal por parte de grandes sociedades comerciais pode lesar os interesses de todos os empreendedores concorrentes; um prestador de serviço que não observa uma cláusula de acordo coletivo pode violar o direito de todos os seus dependentes; resíduos poluentes despejados em um rio prejudicam os moradores ribeirinhos e todos aqueles que pretenderiam usar da água não poluída daquele rio; a embalagem defeituosa ou não higiênica de um artigo de largo consumo leva prejuízo a todos os consumidores daquele bem... Os riscos de tais lesões, que afetam simultaneamente numerosas pessoas, ou categorias inteiras de pessoas, constituem um fenômeno sempre muito vasto e freqüente na sociedade industrial. A pessoa lesada se encontra quase sempre numa situação imprópria para obter a tutela jurisdicional contra $o$ prejuízo advindo individualmente, e pode simplesmente ignorar seus direitos; ou, ainda, suas pretensões individuais podem ser muito limitadas para induzi-la a agir em Juízo, e o risco de incorrer em grandes despesas processuais pode ser desproporcional com respeito ao ressarcimento eventualmente obtível. ${ }^{471}$
\end{abstract}

Foi também em vista dessa constatação que o sistema brasileiro de tutela coletiva desenhou-se sobre um regime plural de representação dos interesses, segundo o qual a titularidade da ação é outorgada concorrentemente a associações, a certos entes despersonalizados, a certos órgãos e entes públicos e, finalmente, ao Ministério Público. Este, no entanto, sobretudo no início da experiência brasileira com o processo coletivo,

${ }^{471}$ Formações Sociais e Interesses Coletivos diante da Justiça Civil, p. 130. 
acabou por assumir franca primazia na defesa desse tipo de interesse. A razão para tanto é o que tento explorar neste momento.

A questão da sub-representação de certos interesses não é nova, nem exige, obrigatoriamente, soluções estatais para ser contornada. Richard Posner, por exemplo, compara a ação de classe americana à atuação do varejista que, por sua própria atividade, acaba reunindo pleitos dispersos e de pequena monta de seus consumidores para endereçálos, conjuntamente, ao fabricante, que de outra forma não iria jamais conhecer as reclamações desses usuários finais. ${ }^{472}$ Contudo, a experiência institucional do Ministério Público brasileiro parece ter consistido em uma inteligente forma estatal de lidar com esse problema, sobretudo no plano dos interesses incidentes sobre bens coletivos.

No campo da ciência política, talvez a mais importante análise sobre a organização dos interesses ligados a esse tipo de bens seja a de Mancur Olson, consubstanciada em seu trabalho publicado em $1965 .^{473}$

Nesse trabalho, Olson realiza um amplo estudo a respeito da dinâmica dos grupos de interesse, focando suas preocupações de modo particular nos grupos voltados à persecução de bens chamados pelo autor de "bens coletivos", ou seja, de bens que, por sua própria natureza, ao serem fruídos por um dos membros do grupo, necessariamente acabam sendo aproveitados também pelos demais. Exemplos desse tipo de bem seriam a segurança pública, o meio ambiente ecologicamente equilibrado e assim por diante. Seriam bens marcados por uma característica de indivisibilidade.

Ao analisar a dinâmica dos grupos organizados em torno desses bens, Olson principia seu estudo com uma consideração simples porém importante: afirma que o ponto de partida mais lógico para iniciar-se um estudo sistemático das organizações é seu propósito. E afirma, em seguida, que o principal propósito que caracteriza a maior parte das organizações (praticamente todas aquelas dotadas relevância econômica) é a persecução dos interesses de seus membros. Este é, portanto, o tipo de organização abordado no trabalho de Olson. Mais que isso, trata-se de a uma organização que persegue interesses comuns de seus membros, já que os interesses puramente individuais são sempre

${ }^{472}$ Richard Posner, El Análisis Económico del Derecho, p. 534-5.
${ }^{473}$ Mancur Olson, The Logic of Collective Action: Public Goods and the Theory of Groups. 
melhor perseguidos, segundo o autor, de forma isolada ${ }^{474}$. Olson não nega, evidentemente, que os membros de uma dada organização tenham inúmeros interesses puramente individuais, diferentes dos interesses dos demais membros. Mas afirma que a organização só faz sentido para perseguir os interesses que são comuns a todos os membros do grupo. A própria idéia de grupo implicaria, portanto, a existência de interesses comuns em relação a seus membros. ${ }^{475}$

Olson afirma haver um paralelo entre a combinação dos interesses individuais e comuns das pessoas, dentro de uma organização, e a combinação dos interesses individuais e comuns das empresas, num mercado competitivo. Num mercado competitivo, todos os competidores teriam interesse, em tese, em maximizar seus preços, para maximizar assim os seus lucros, mantendo, portanto, restrito o nível de sua produção. A decisão coletiva mais racional seria essa. No entanto, o que ocorre no mercado é que cada um age em benefício de seu próprio interesse, desconsiderando os efeitos de sua conduta sobre o mercado todo. Cada empresa aumenta a sua produção para maximizar seu ganho, e o aumento geral da produção derruba os preços. Do prisma individual, essa é a escolha racional a fazer em um mercado perfeitamente competitivo (pesando custos e benefícios próprios), ainda que não seja, do ponto de vista coletivo, a escolha mais inteligente para o grupo como um todo. Da mesma forma, ninguém, individualmente, sacrificaria seu próprio tempo e dinheiro em uma organização que se destinasse a obter ajuda governamental para uma dada indústria se auferisse, com isso, um benefício indireto menor que os custos envolvidos na obtenção daquela determinada ajuda ${ }^{476}$. Se o benefício, espalhado por toda a indústria, não compensar individualmente o custo alocado em sua obtenção, dificilmente alguém se lançará a persegui-lo. Olson demonstra que quanto maior é o número de empresas no mercado, maior é esse efeito, pois menos cada empresa sentirá que sua ação individual pode (i) provocar reações diversas nos comportamentos alheios, ou (ii) ser, ultimamente, responsável pelo resultado global a ser atingido.

Muitos objetam (Olson mesmo o reconhece) que esse paralelo entre as organizações e o mercado não seria totalmente adequado, pois o comportamento das pessoas em uma organização leva em conta fatores emocionais e ideológicos que deveriam mudar a análise neste campo. Todavia, segundo Olson, a observação empírica negaria essa

\footnotetext{
${ }^{474}$ Ob. cit., p. 5-6.

475 Ob. cit., p. 7.

476 Ob. cit., p. 11.
} 
objeção, como seria possível verificar com um exemplo prático muito comum: o pagamento de impostos.

Para Olson, se efetivamente fossem determinantes para o comportamento dos grupos as considerações de natureza ideológica, seria necessário admitir que essas considerações ideológicas deveriam necessariamente levar as pessoas ao pagamento espontâneo de impostos, pois esse pagamento reverte indiretamente para o bem de todos os indivíduos e é, portanto, o preço natural a pagar por um benefício importante e que a todos aproveita. Contudo, a verdade é que ninguém paga impostos espontaneamente, justificando-se assim a existência de leis que obrigam a contribuição individual para a arrecadação estatal. Segundo Olson, isso acontece porque o bem comum custeado com os impostos é tal que, na maioria das vezes, sua fruição por um indivíduo implica sua fruição por todos os demais (segurança, serviços judiciários, limpeza pública, etc.). Pela conjunção desses fatores, o comportamento racional das pessoas é tentar "pegar carona" (to free ride) nas contribuições alheias, usufruindo assim o bem público a custo zero.

Olson demonstra que o comportamento de um membro de uma grande organização é efetivamente análogo ao de uma empresa em um mercado perfeitamente competitivo, ou ao de um contribuinte do Estado, como no exemplo acima indicado. Seus próprios esforços não têm efeito notável na situação de sua organização, e ele pode desfrutar dos benefícios trazidos pelas contribuições de outras pessoas sem que isso implique sua participação na organização. Por essa razão, grandes organizações que não podem tornar a associação a si compulsória devem prover a seus membros benefícios não coletivos que estimulem a $\operatorname{associação~}^{477}$.

Segundo Olson, as teorias tradicionais dos grupos partiriam, por isso, de pressupostos equivocados, ao imaginar que as organizações em geral funcionem de maneira inteiramente diferente das regras que governam as relações entre empresas em um mercado. Segundo a narrativa de Olson, elas tenderiam, de forma direta ou indireta, a querer explicar as razões do associativismo humano a partir de uma simplificação inaceitável, consistente na "tendência", ou "instinto", próprios da espécie humana, de organizar-se em grupo. Partindo dessa premissa, a teoria tradicional dos grupos imaginaria que as organizações de pequenas e grandes dimensões tenderiam a atrair membros com a

${ }^{477}$ Ob. cit., p. 16. 
mesma intensidade, pois o impulso de associar-se a umas ou outras seria o mesmo. A teoria tradicional dos grupos não dividiria as organizações, para efeitos de análise, entre pequenas e grandes organizações. Todavia, pesquisas empíricas mostrariam que as pessoas normalmente não se associam espontaneamente a grandes organizações. A explicação para esse comportamento é efetivada pelo autor por meio do recurso a ferramentas econômicas e matemáticas, chegando, assim, a conclusões as mais interessantes.

Segundo Olson, a análise empírica do comportamento das pessoas em relação à persecução de bens comuns mostra que certos grupos pequenos podem prover a si mesmos com bens coletivos sem necessitar depender de quaisquer estímulos externos sobre seus membros para atingirem esse objetivo ${ }^{478}$. Para o autor, isso aconteceria porque nesses pequenos grupos cada um dos membros, ou ao menos um deles, experimentará um ganho pessoal tão grande com a fruição do bem, que esse ganho compensará até mesmo o custo total de sua obtenção. Em situações tais, o bem coletivo provavelmente será atingido, e muito provavelmente isso ocorrerá em virtude da ação voluntária, orientada pelo próprio interesse, de um ou mais membros do grupo. Isso ocorre em grupos pequenos nos quais o ganho individual supera o custo total de obtenção do bem para todos os membros, e também naqueles em que o ganho individual experimentado pelos membros é desigual em tal intensidade que um deles, a quem o bem mais aproveitar, provavelmente irá lançar esforços para obtê-lo, beneficiando com isso os demais.

Mesmo nesses pequenos grupos, contudo, o bem coletivo tende a não ser fornecido a todos os membros em uma escala ótima ${ }^{479}$. A tendência a esse aproveitamento sub-ótimo ocorre porque o investimento individual na obtenção do bem é compensado por um ganho que se divide de forma difusa no grupo. Assim, cada membro do grupo tenderá a reduzir seus esforços na obtenção do bem comum antes que se chegue a uma escala que pudesse ser considerada ótima para todo o grupo. Nota-se também que quanto maior o grupo, mais distante ele estará de atingir um nível ótimo de fornecimento do bem coletivo em questão.

Esse caráter ineficiente na ação dos grupos tende a reduzir-se na medida em que a distribuição dos benefícios entre os membros de uma dada organização é mais desigual. Nessa hipótese, haverá uma tendência à distribuição desigual dos ônus decorrentes da

\footnotetext{
${ }^{478}$ Ob. cit., p. 33.

${ }^{479}$ Ob. cit., p. 35.
} 
obtenção do bem, já que os benefícios dele derivados também são desiguais. Há, nessas hipóteses, uma tendência de "exploração" do pequeno pelo grande ${ }^{480}$.

Os grupos pequenos, portanto, diferenciam-se dos grandes na medida em que os primeiros tendem a atingir os bens coletivos simplesmente pela atração que esses bens provocam em cada membro individualmente considerado. Nos grupos grandes, o interesse individual de cada membro não compensará os custos individuais para obtenção do bem em questão. Quanto maior o grupo, menor será sua capacidade de atingir bens coletivos, destinados à fruição de todos os seus membros.

Nesse ponto, Olson aponta uma importante diferença entre o comportamento das indústrias em um determinado mercado e o comportamento dos grupos de interesse atuantes na sociedade. Essa diferença consiste, substancialmente, em suas respectivas atitudes quanto à entrada e saída de membros. As empresas em um mercado são competidoras umas das outras. Entre grupos perseguindo bens coletivos a posição é exatamente oposta. Se o desejo de uma empresa é reduzir o número de empresas competidoras, o desejo de um membro de um grupo de interesse é sempre o de aumentar o número de membros desse grupo, para com isso reduzir os custos daqueles que já são membros. A diferença entre essas posturas consiste no caráter coletivo do bem perseguido pelos grupos de interesse, cuja fruição por um membro não reduz ou interfere com sua fruição pelos demais membros, ao contrário do que ocorre em um mercado competitivo.

O bem coletivo cuja fruição por um membro da coletividade exclui ou reduz em alguma maneira a fruição dos demais deveria por isso ser chamado de "exclusivo". Ao contrário, aquele cuja fruição por um membro não reduz ou impede a fruição dos demais deveria ser chamado de "inclusivo"481. Assim, explicitando um pouco melhor suas conclusões a respeito do comportamento dos grupos de interesse, Olson explica que $a$ natureza inclusiva ou exclusiva desse comportamento depende mais da natureza dos objetivos (bens coletivos) perseguidos pelo grupo, que de qualquer característica intrínseca à própria associação.

Quando um grupo persegue bens de natureza inclusiva não é essencial que cada indivíduo participe ativamente da organização ou do acordo que a ela subjaze (ao

\footnotetext{
${ }^{480}$ Ob. cit., idem.

${ }^{481}$ Ob. cit., p. 36-8.
} 
contrário, o normal é que essa participação não ocorra). Contudo, quando o bem perseguido é de natureza exclusiva (manter preços artificialmente altos em um cartel, por exemplo), é essencial que todos os membros participem da organização e do acordo a ela subjacente (all-or-none quality of the exclusive groups). Nesses últimos, ademais, o acordo só será atingido se o número de membros for relativamente pequeno (daí a tendência dos mercados em que atuam poucas empresas de tornarem-se oligopolistas). Isso, ao revés, não acontece nos grupos não exclusivos, onde as ações interindividuais são muito menos estratégicas e muito mais independentes.

Da conjunção dessas várias conclusões tiradas pelo autor poder-se-ia determinar que a chance de um grupo atingir ou não os seus objetivos dependeria em larga medida do tamanho desse grupo, do tipo de bem perseguido e do interesse de cada membro na obtenção do bem em questão. Poder-se-iam imaginar, então, três situações distintas quanto à probabilidade de atendimento de objetivos coletivos.

Em primeiro lugar, seria de se presumir o sucesso de pequenos grupos na obtenção de um dado bem coletivo, especialmente daqueles em que um determinado membro beneficia-se do bem coletivo em escala tal que lhe será melhor pagar todos os custos de obtenção do bem que ficar sem ele.

Numa segunda hipótese, tratando-se de um grupo no qual nenhum membro tem tamanho interesse no bem que justifique suportar individualmente seu custo, mas no qual cada ação individual permaneça importante em relação a todo o grupo, quer no que diz respeito à sua contribuição para o resultado comum, quer no que respeita à distribuição de custos e benefícios, será difícil determinar, de antemão, se o bem será atingido ou não.

Finalmente, é de se presumir que o bem coletivo não será atingido por grandes grupos nos quais cada contribuição individual não possa fazer uma diferença perceptível para o grupo como um todo, ou para os ônus ou benefícios a serem experimentados por cada outro membro individualmente considerado. Nesses grupos, o bem só será atingido se houver algum tipo de estímulo ou coerção externos, que visem a forçar as contribuições de cada membro para a consecução do objetivo comum.

A capacidade de um grupo atingir seus objetivos depende portanto do número de seus membros e, como dito, da natureza inclusiva ou exclusiva do bem perseguido. 
Contudo, não é exato dizer que essa capacidade dependa só disso. As relações entre o tamanho de um grupo e a importância de cada participação individual influenciam essa capacidade. Assim, grupos cujos membros apresentem graus muito diferentes de interesse no bem coletivo podem atingi-lo mesmo que seu tamanho seja expressivo, desde que o bem em questão seja tão valioso para um ou alguns de seus membros que estes se disponham a suportar sozinhos os custos de sua obtenção. Assim, o principal critério para determinar a capacidade de uma dada coletividade de atingir objetivos comuns será basicamente o mesmo para grupos que atuam dentro ou fora de um mercado: essa capacidade dependerá da importância que cada ação individual exercer em relação às posições dos demais membros do grupo. Quanto maior essa importância, maior a chance de obtenção do bem. Quanto menor, menos provável será essa obtenção. E essa importância, obviamente, é, entre outras, uma função do tamanho do grupo. ${ }^{482}$

Prosseguindo em sua análise, Olson pondera haver três principais fatores que, cumulados, impedem o atendimento dos objetivos comuns de grupos dispersos e numerosos. Esses fatores são os seguintes: (1) quanto maior for o grupo, menor será, proporcionalmente, a parcela individual de benefício que cada membro experimentará com a obtenção do bem coletivo; assim, menor será o prêmio individualmente recebido por uma ação orientada para a persecução dos objetivos do grupo; (2) quanto maior for o grupo e menor for o benefício proporcional, menor será também a probabilidade de esse benefício individual superar os custos que a ação orientada para o grupo envolverá; (3) finalmente, quanto maior for o grupo, maiores serão os custos a serem suportados pela organização e, portanto, maior deverá ser o benefício individual decorrente da obtenção do bem comum para que faça sentido econômico persegui- $10^{483}$.

Com base nesses elementos, Olson faz uma classificação dos grupos de interesse não atuantes em mercado baseada em seu tamanho e na probabilidade de atendimento do objetivo comum por eles perseguido. Essa classificação pode revelar-se útil ao estudo da tutela de interesses difusos e coletivos, como quero demonstrar adiante. Segundo esses critérios, os grupos dividir-se-iam em: (i) grupos privilegiados: equivaleriam a um grupo de empresas em situação de oligopólio. Neles, ao menos um membro tem incentivos bastantes que o levem a providenciar o atendimento do bem, mesmo que ele tenha que

\footnotetext{
482 Ob. cit., p. 45.

483 Ob. cit., p. 48.
} 
suportar todo o custo de obtenção desse bem. Nesses grupos, o bem provavelmente será obtido, mesmo sem qualquer organização dos indivíduos interessados em sua obtenção; (ii) grupos intermediários: também corresponderiam a um grupo de empresas em situação de oligopólio. No entanto, nenhum membro suportaria sozinho todos os custos de obtenção do bem. Apesar disso, o número de interessados não é tão grande a ponto de ser indiferente cada comportamento individual. Nesses grupos, o bem poderá ou não ser obtido, mas dificilmente o será sem algum grau de organização dos interessados; (iii) grupos "latentes" ou muito grandes: corresponderiam a empresas em um mercado perfeitamente competitivo. O número de membros é tal que cada ação individual não é percebida imediatamente de forma benéfica ou prejudicial pelos demais membros. Ninguém tem interesse em colaborar espontaneamente com o atendimento do objetivo comum. ${ }^{484}$

Segundo Olson, nos grupos latentes apenas um incentivo individual e distinto do atendimento do bem comum poderia estimular os membros do grupo à participação (selective incentives). Esses incentivos podem ser positivos ou negativos, ou seja, podem servir para punir aqueles que não contribuem ou para agregar vantagens individuais aos que contribuem. Se esses incentivos ocorrerem, diz-se que o grupo foi "mobilizado" e, dessa forma, é possível que o interesse comum seja atingido. Tais grupos chamam-se latentes, então, exatamente por esse potencial que têm para serem, ou não, mobilizados em prol do interesse comum. Se não o forem (hipótese mais comum, aliás, na sociedade), é possível dizer com razoável grau de certeza que o objetivo comum por eles perseguido não irá ser atingido.

Voltando ao problema do processo coletivo brasileiro, já é possível, a essa altura, constatar o óbvio: na maior parte das vezes, os interesses sobre bens coletivos (tais como o patrimônio histórico e cultural, o meio ambiente, e outros semelhantes), caracterizam-se como interesses de grupos latentes. Isso significa dizer, em última análise, que o bem coletivo de titulação excessivamente difusa tem poucas ou nenhuma chance de ser protegido ou perseguido por iniciativa espontânea daqueles diretamente interessados em sua obtenção. Isso vale tanto para o plano político quanto para o plano judicial, pois “o

${ }^{484}$ Ob. cit., p. 49-52. 
processo coletivo é uma forma de ação coletiva e, como uma forma de ação coletiva, divide as mesmas características dessa última". ${ }^{485}$

Analisando a tutela processual do meio ambiente, Carlos Salles chega a essa mesma conclusão, ponderando que os custos da defesa judicial de interesses difusos e coletivos por cada indivíduo são sempre altos demais em relação à parcela de interesse pessoal per capta, a qual é geralmente muito pequena para justificar tais custos. Nessa tutela, verifica-se claramente o fenômeno do "free-rider", apontado pioneiramente por Olson. $^{486}$

Em vista dessa constatação, torna-se central ao problema da tutela de interesses difusos e coletivos definir a questão da sua representação. Trata-se, basicamente, de responder a duas perguntas fundamentais: quem irá defender esses interesses? E como? A solução brasileira apostou na representação semi-pública, como visto acima, e parece, com isso, ter superado alguns desses problemas de sub-representação.

De fato, as primeiras pesquisas empíricas feitas a respeito da tutela coletiva no Brasil apontaram, claramente, para a prevalência da ação oficial oriunda do Ministério Público. Uma das mais conhecidas, empreendida por Pinheiro Carneiro, analisou as ações civis públicas ajuizadas na Comarca do Rio de Janeiro entre os anos de 1985 e 1996, tendo concluído que o Ministério Público era responsável, então, por mais de $65 \%$ das ações ajuizadas (vide, nesse sentido, a Tabela 04 abaixo).

A solução institucional baseada na figura do Ministério Público contorna os problemas de sub-representação exatamente no ponto em que eles são mais sensíveis: no campo dos interesses sobre bens indivisíveis, normalmente identificados, no Brasil, com a categoria dos interesses difusos. Como dito antes, essa solução tem, por isso, uma clara vantagem quando comparada ao modelo americano, que é confirmada pelos dados empíricos disponíveis $^{487}$. Mas sua desvantagem, igualmente apontada acima, também transparece empiricamente: ao não acreditar na tutela individual e ao não conceder qualquer benefício específico à ação particular em defesa de interesses privados

\footnotetext{
485 Stephen Yeazell, Collective litigation as collective action, p. 44.

${ }^{486}$ Carlos Alberto de Salles, Execução Judicial em Matéria Ambiental, p. 128-9.

487 O papel atribuído ao Ministério Público acaba funcionando como um "redutor dos custos de organização" (Cf. Julio Aurélio Vianna Lopes. Democracia associativa e a Constituição de 1988: o novo Ministério Público Brasileiro. Rio de Janeiro: IUPERJ. Tese de Doutorado, 1998, p, 156, apud Luiz Werneck Vianna e Marcelo Burgos. Revolução processual do direito e democracia progressiva).
} 
excessivamente dispersos, a solução da lei acaba por fazer o pêndulo do processo coletivo tombar excessivamente em direção à tutela dos bens indivisíveis, reduzindo os potenciais de persecução de pequenos interesses individuais lesados coletivamente. Assim, na mesma pesquisa referida acima, constatou-se que quase $60 \%$ das ações voltava-se à tutela de interesses difusos, ao passo em que apenas 4,6\% dirigiam-se à tutela de direitos individuais homogêneos.

Ministério Público Estadual

Associações e ONGs

Município do Rio de Janeiro

Total
192 Casos

39 Casos

35 Casos

266 Casos
$66,31 \%$

$13,68 \%$

$11,28 \%$

$91,27 \%(*)$

(Fonte: Paulo Cezar Pinheiro Carneiro, Acesso à Justiça, Rio de Janeiro: Forense, 1999, p.82). (*) O total é inferior a 100\% em virtude da existência de outras categorias de demandantes, como, por exemplo, partidos políticos.

\section{(Tabela 05)}

TIPO DE INTERESSE DEMANDADO

(Por categoria processual) $(1985-1996)$

$\begin{array}{lr}\text { Interesse difuso apenas } & 57,47 \% \\ \text { Interesse difuso e coletivo } & 8,04 \% \\ \text { Interesse coletivo apenas } & 16,09 \% \\ \text { Direitos individuais homogêneos } & 4,59 \% \\ \text { Interesses difusos e direitos individuais homogêneos } & 2,30 \% \\ \text { Interesses coletivos e direitos individuais homogêneos } & 5,74 \% \\ \text { Interesses difusos e coletivos e direitos individuais homogêneos } & 5,74 \% \\ & \\ \text { Total } & 99,97 \%\end{array}$

(Fonte: Paulo Cezar Pinheiro Carneiro, Acesso à Justiça, Rio de Janeiro: Forense, 1999). (*) O total é inferior a 100\% em virtude da aproximação dos valores percentuais para a segunda casa decimal

Esses dados remetem a uma idéia que vem tomando corpo no meio acadêmico, tendente a responsabilizar a ação intensa do Ministério Público na tutela de interesses difusos e coletivos pelo "atraso" havido na mobilização da própria sociedade civil para a 
persecução desses interesses, em áreas como a tutela do mercado de consumo, do meio ambiente, da propaganda na mídia e assim por diante ${ }^{488}$.

À luz das noções trazidas pela análise econômica dos grupos de interesse, haveria, é certo, algumas objeções a esse tipo de análise. Sobretudo, a de que se estaria diante de interesses cuja tendência à sub-representação é muito intensa, de sorte que o imobilismo poderia decorrer menos da ação inflacionada do Ministério Público que das próprias características desses interesses, em que preponderam (i) insignificância da parcela individual de benefício que cada membro experimenta com a sua obtenção, (ii) a desproporção relativa dos custos a serem suportados pela sua persecução e (iii) o equilíbrio excessivo nas parcelas de interesse individual de cada interessado em relação à obtenção do bem, desestimulando ações individuais tendentes à sua obtenção e estimulado o chamado efeito caronista (oportunista).

Não se desconhece em absoluto a crítica incisiva que já se fez, especialmente no direito estrangeiro, às chamadas soluções "publicistas" de tutela dos interesses difusos e coletivos, especialmente daquela fundada em figuras assemelhadas ao Parquet francês. Entre essas críticas, talvez a mais conhecida seja a apresentada pelo relatório de Cappelletti ao $9^{\circ}$ Congresso da International Academy of Comparative Law, ocorrido em Teerã. ${ }^{489}$

Em seu estudo, Cappelletti pondera, inicialmente, que a tutela de interesses coletivos e difusos já se revelaria, de plano, substancialmente distinta da tutela dos interesses que tradicionalmente eram confiados ao Ministério Público (primazia da ação penal, tutela do matrimônio, etc.), e à qual essa instituição era tradicionalmente adaptada. Partindo do princípio de que a proteção dos interesses coletivos e difusos traduzir-se-ia também em novidade para o próprio Parquet, Cappelletti compara a utilização desse órgão (por ele chamada de solução publicista, englobando também as figuras do attorney general anglo-americano e da prokuratura soviética) com outras possíveis formas de tutela desses interesses, como a tutela direta pelos particulares eventualmente interessados (a solução

\footnotetext{
${ }^{488}$ Kazuo Watanabe afirma, por exemplo, haver certo "paternalismo estatal exagerado" na tutela coletiva do mercado de consumo (Código Brasileiro de Defesa do Consumidor Comentado pelos Autores do Anteprojeto, p. 760). Por seu turno, Antonio Augusto Mello de Camargo Ferraz reconhece que "talvez seja exacerbada a preponderância do Ministério Público dentre os vários co-legitimados para o exercício da ação [civil pública]", ponderando que a "multiplicação de casos a cargo do Ministério Público expõe... a Instituição a graves riscos, como o do indevido inchaço de seus quadros, o da banalização e burocratização da atuação e, sobretudo, o da perda de eficiência no enfrentamento das questões mais sérias e de maior relevância social" (Ação Civil Pública, Inquérito Civil e Ministério Público, p. 91)

${ }^{489}$ Cappelletti, The Role of the Ministère Public (...).
} 
privatista das class actions americanas) e a tutela por associações e organizações especializadas na defesa desses interesses (a solução privatista-associativista, na dicção de Cappelletti $)^{490}$.

Cappelletti procura compreender as "ambigüidades" típicas do Ministério Público, por ele tratado como um personagem a meio caminho entre o juiz e a parte, entre o judiciário e o executivo. Pondera que a instituição tem, no direito comparado, um viés mais próprio ao de um auxiliar da justiça que ao de parte, ponderando ainda que lhe falta, por sua própria estrutura organizacional, pelo método de recrutamento que lhe é próprio, e por inúmeros outros fatores, o grau de comprometimento com os interesses difusos necessário a que o Parquet pudesse efetivamente se tornar um "ator ideológico", ao invés de um "agente meramente burocrático" incumbido da defesa desses interesses. Especialmente centrado na análise do Ministério Público na França, Bélgica e Itália, o autor conclui que o Ministério Público seria incapaz de erigir-se para a defesa eficaz de interesses coletivos nas sociedades modernas, em virtude de inúmeros fatores, como (i) falta de especialização adequada, (ii) excesso de hierarquização e burocracia, (iii) rigidez organizacional e falta de agressividade, (iv) eventual promiscuidade na ligação de seus membros com a magistratura, etc. ${ }^{491}$. Em face dessas constatações, Cappelletti faz um apelo a uma solução pluralista, consistente em permitir a tutela dos interesses difusos pelos mais diversos meios complementares, incluindo não apenas a ação coadjuvante do Ministério Público, mas também outorgando-se legitimação para particulares e associações, para órgãos públicos especializados (como o ombudsman dos consumidores na Suécia) e compensando-se a eventual falta de comprometimento dessas partes ideológicas com um papel ativo do juiz no processo. ${ }^{492}$

O caso brasileiro tendeu a essa solução plural, mas remete a um arranjo institucional particular, uma vez que a Constituição de 1988 afastou bastante o Ministério Público daquela instituição de modelo francês criticada pela literatura estrangeira. No direito nacional o órgão não tem mais aquela intensa conotação híbrida, a meio caminho entre o juiz e a parte, entre o judiciário e o executivo. O Ministério Público foi dotado de boa dose de autonomia institucional e o que se vê de sua atuação prática é, efetivamente, mais a ação de um "ator ideológico" que aquela de um "agente meramente burocrático",

\footnotetext{
${ }^{490}$ Idem, p. 13-24.

${ }^{491}$ Idem, p. 25-99

492 Idem, p. 148-156.
} 
para o bem e para o mal. Nosso Ministério Público é especializado, é menos burocratizado que seus pares europeus e foi dotado pela lei de importante instrumento instrutório (o inquérito civil). Nesse contexto, a ele não se aplicariam, em princípio, várias das críticas lançadas por Cappelletti em seu famoso estudo. ${ }^{493}$

Isso não exclui, é claro, que se possa pensar em alternativas legais ou de outra natureza voltadas a promover o associativismo e a participação da sociedade na tutela desses bens. Essa participação, por sinal, parece ter aumentado, como indica uma pesquisa subseqüente feita por Vianna e Burgos na mesma Comarca do Rio de Janeiro, em que constatou-se, de 1996 para cá, importantíssimo acréscimo na participação das associações em relação ao total de ações civis públicas ajuizadas (v. Tabela 06 e Gráfico 04 abaixo)., Essa participação, conduto, parece dar-se exatamente no âmbito de interesses ligados às porções intermediárias da sociedade, em que a organização popular encontra mais estímulos e menos empecilhos (direitos de consumo, em especial). Enquanto as associações e ONGs responderam por $68,7 \%$ de todas as ações ajuizadas na área de consumo $^{494}$, na área de proteção à criança e adolescente elas responderam por apenas $4 \%$ desse total, tendo sido todas as ações restantes (96\%) de responsabilidade do Ministério Público ${ }^{495}$. Além disso, as chances de êxito das ações promovidas pelo Ministério Público parecem ser duas vezes maiores que aquelas atinentes às ONGs. ${ }^{496}$

Ministério Público Estadual Associações, ONGs e sindicatos Município do Rio de Janeiro Outros

$\begin{array}{cc}179 \text { Casos } & 42,7 \% \\ 70 \text { Casos } & 37,7 \% \\ 30 \text { Casos } & 16,2 \% \\ 6 \text { Casos } & 3,2 \%\end{array}$

(Fonte: Luiz Werneck Vianna e Marcelo Burgos, Revolução processual do direito e democracia progressiva, in Luiz Werneck Vianna (org.), A democracia e os três poderes no Brasil, Rio de Janeiro: IUPERJ/FAPERJ, 2002, p. 465). O total da amostra foi de 185 casos.

493 Com efeito, as críticas de Cappelletti à tutela de interesses difusos pelo Parquet teriam sido fortemente mitigadas pelo próprio professor da Universidade de Firenzi, à luz das características próprias (especialmente a especialização e independência funcional) ao Ministério Público brasileiro. É o que anotam Carlos Alberto de Salles (ob. cit., p. 147), Rodolfo de Camargo Mancuso (Ação Civil Pública, p. 92, nota 16) e Hugo Nigro Mazili (A defesa interesses difusos em juizo, p. 45, apud Mancuso, ob. cit., p. 92).

${ }^{494}$ Luiz Werneck Vianna e Marcelo Burgos, Revolução processual do direito e democracia progressiva, $\mathrm{p}$. 471.

495 Idem, p. 476.

496 Idem, p. 481. 
É claro que a ação do Ministério Público pode envolver (quase sempre envolve) certa visão paternalista da sociedade. ${ }^{497}$ É igualmente certo que a representação pública dos interesses difusos acaba por acentuar ainda mais a falsa unidade desses mesmos interesses, conforme referi acima, colaborando para mascarar o caráter policêntrico dos conflitos que os envolvem. Também não ousaria duvidar da necessidade de avançar-se, em um futuro próximo, no sentido de adicionar à solução brasileira uma boa dose das alternativas privatistas referidas na experiência americana. ${ }^{498}$ No entanto, parece-me claro que a figura institucional do Ministério Público brasileiro vem responder a uma dada demanda social intensamente sentida no contexto nacional presente, a qual, sem ela, teria um canal de expressão a menos.

\section{(Gráfico 04) \\ PARTICIPAÇÃO DA SOCIEDADE CIVIL NO AJUIZAMENTO TOTAL DE AÇÕES CIVIS PÚBLICAS (1998-2001)}

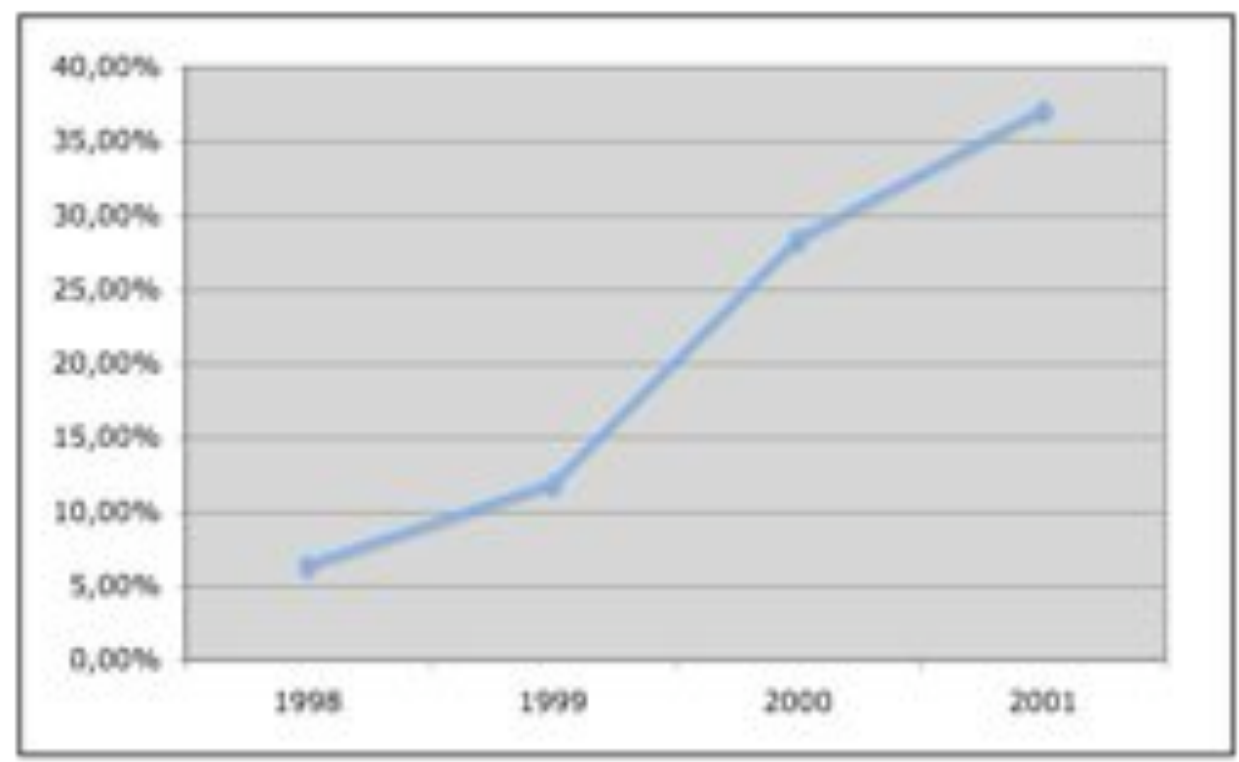

(Fonte: Luiz Werneck Vianna e Marcelo Burgos, Revolução processual do direito e democracia progressiva, in Luiz Werneck Vianna (org.), A democracia e os três poderes no Brasil, Rio de Janeiro: IUPERJ/FAPERJ, 2002, p. 434).

Essa resposta não é imune a conseqüências, e tem provocado modificações expressivas na instituição por que opera. Essa instituição, que agora precisa fazer as vezes de parte e não de fiscal da lei, torna-se, por efeito de suas novas atribuições, efetivamente mais "agressiva”, assumindo nesses litígios um comportamento completamente parcial.

${ }^{497}$ V., a propósito, as informações referidas na nota 161, na primeira parte deste trabalho.

${ }^{498}$ V. tb., sobre essas alternativas centradas na figura do private attorney general, Owen M. Fiss, The Political Theory of Class Actions. V. ainda, sobre as propostas de reforma em curso, aquela contida no j'a referido Anteprojeto de Código Brasileiro de Processos Coletivos, em que a legitimação individual é acrescentada às hipóteses já existentes de defesa de interesses difusos e coletivos. 
Da narrativa feita acima, percebe-se que a principal crítica feita à atuação do Ministério Público na Europa consistia, justamente, em sua "frieza institucional", em sua "falta de agressividade", no dizer de Cappelletti. A ação enfática da instituição no Brasil consiste em sua força e na razão principal de seu relativo sucesso na persecução dos interesses difusos e coletivos. Mas consiste, também, em elemento desestabilizador daquela legitimidade própria à fiscalização da lei. Este é, talvez, um papel que se perderá no dia a dia da instituição.

\section{IV}

\section{O JUIZ, A LEI E O "MODO DE SER" DO PROCESSO}

No plano estrito do procedimento também são notadas, como visto acima, importantes modificações na estrutura do contencioso civil brasileiro. Mais uma vez, essas modificações são conseqüência e, em larga medida, tentativas de resposta ao desenho particular dos novos conflitos.

Essas modificações no "modo de ser" do processo civil operam, sobretudo, em 3 planos. Primeiro, flexibilizam as regras de procedimento, concentrando poderes de gestão processual nas mãos do juiz. O juiz passa, pouco a pouco, a "desenhar o procedimento" de acordo com as necessidades do caso a resolver, ao invés de adaptar essas necessidades ao rol taxativo de procedimentos previstos rigidamente em lei. ${ }^{499}$ Segundo, vão pouco a pouco flexibilizando o caráter parte-controlado do processo. Isso faz com que os termos do conflito, que originalmente eram dados de forma rígida pelo próprio autor em seu ato inicial de comparecimento a juízo (a demanda), paulatinamente passem a ser objeto de redefinição ao longo do processo, não raro com a colaboração e intervenção do próprio órgão judicial. Terceiro, flexibilizam-se os mecanismos de prova técnica, que vão deixando de consubstanciar-se em uma opinião dada por um técnico distante do conflito para transformarem-se em mecanismos de informação do magistrado acerca das variáveis

${ }^{499}$ V. a respeito, José Roberto dos Santos Bedaque. Efetividade do Processo e Técnica Processual: Tentativa de Compatibilização, p. 104-5. O Código de Processo Civil Português positivou esse princípio da adequação formal em seu artigo 265-A: "Quando a tramitação processual prevista na lei não se adequar às especificidades da causa, deve o juiz oficiosamente, ouvidas as partes, determinar a prática dos actos que melhor se ajustem ao fim do processo, bem como as necessárias adaptações." 
técnicas envolvidas na decisão. Além disso, a fortalecem-se, paralelamente, os poderes de instrução do juízo, que passa a agir, independentemente, em busca da prova necessária à decisão. ${ }^{500}$

Os novos conflitos de natureza pública submetidos à justiça brasileira são, como vistos, em grande parte conflitos de justiça distributiva nos termos definidos anteriormente, isto é, são conflitos que envolvem a alocação de recursos ainda não apropriados. São embates entre interesses vários e conflitantes em torno de um bem comum que precisa ser compartido entre muitos. Isso significa, é certo, que tais embates não se estruturam em uma dinâmica de oposição adversarial. Mas também significa que nenhuma das partes no conflito poderá invocar ius dominus sobre o bem litigado, não detendo, por isso, poderes de controle e manipulação sobre ele.

São também conflitos que envolvem com freqüência variáveis técnicas (por vezes, até mesmo conhecimentos específicos sobre a realidade social subjacente). Essas variáveis, assim como os próprios conflitos, projetam-se para o futuro, para a implementação de alterações e reorganizações na realidade. Os conflitos são de justiça dinâmica, ${ }^{501}$ cuja solução implica um olhar conseqüencialista, antes prospectivo que retrospectivo. Por isso, as variáveis técnicas incidem em geral na avaliação das conseqüências, e não na definição de fatos passados que possam suportar uma decisão baseada em silogismos.

Essas peculiaridades explicam as mudanças que referi acima e pressionam o movimento de evolução (ainda que não intencional) do sistema processual em direção a seu aprofundamento. Isso ocorre porque: (i) a justificativa tradicional para o controle da parte sobre o conteúdo do processo consistia exatamente em seu poder de disposição sobre o interesse substancial (sobre o direito subjetivo) litigado, poder esse que, nos novos conflitos, não existe mais; (ii) a estrutura tradicional da prova técnica sempre se destinou à determinação científica da ocorrência ou não de certos fatos passados (paternidade, defeitos de fabricação, culpa por um acidente ao volante), mas não à transmissão de conhecimentos técnicos aplicados ao juízo, para que este formule, por si mesmo, raciocínios consequencialistas, e (iii) a estrutura rígida do procedimento fora pensada para governar conflitos estáveis, que não modificam seus termos de embate ao longo do

\footnotetext{
${ }^{500}$ V. José Roberto dos Santos Bedaque, Poderes Instrutórios do Juiz, passim.

${ }^{501}$ Cf. José Reinaldo Lima Lopes, Justiça e Poder Judiciário.., p. 31.
} 
processo, e que se desenvolvem em estruturas perfeitamente dialéticas (um ataque gerando uma resposta).

Em um artigo de 1977, Stephen Yeazell chamou a atenção de seus leitores para um fato que lhe parecia marcante em certas ações ligadas à "dessegregação" de escolas em Los Angeles: ao invés de espelharem a estrutura dialética tradicional do contencioso em matéria civil, as audiências realizadas nesse caso lembravam mais "assembléias municipais". ${ }^{502}$ Em seu texto, o autor chamava a atenção para a necessidade de reconhecer que a estrutura policêntrica desse tipo de conflito demandava soluções não tradicionais de intervenção de partes, sendo um equívoco tentar acomodar essas soluções nas categorias processuais tradicionalmente pensadas para conflitos de outra espécie. Na experiência brasileira recente, inúmeros exemplos de "assembléias municipais" como essas poderiam remeter a essa análise feita quase trinta anos atrás por Yeazell, demonstrando, em larga medida, as transformações que estou tentando identificar (e talvez a necessidade de novas soluções legislativas, como sugeria o autor).

Vários desses exemplos são referidos no texto já mencionado anteriormente de Joaquim Falcão, envolvendo ocupações clandestinas de terras ${ }^{503}$. Mas um outro exemplo mais "institucionalizado" pode ser, como também já dito, tirado do controle concentrado de constitucionalidade. Basta pensar, nesse sentido, na Argüição de Descumprimento de Preceito Fundamental n. 54, em curso de julgamento perante o Supremo Tribunal Federal, na qual encontra-se em questão a interpretação dos artigos do Código Penal relativos ao aborto, vis-a-vis os casos de "antecipação terapêutica do parto", previstos para os quadros de anencefalia fetal. Após concessão da liminar, o relator do caso, Ministro Marco Aurélio, proferiu, em 30 de setembro de 2004, a seguinte decisão:

\footnotetext{
"A matéria em análise deságua em questionamentos múltiplos. A repercussão do que decidido sob o ângulo precário e efêmero da medida liminar redundou na emissão de entendimentos diversos, atuando a própria sociedade. Daí a conveniência de acionar-se o disposto no artigo $6^{\circ}$, $\S 1^{\circ}$, da Lei $n^{\circ} 9882$, de 3/12/99(...) então, tenho como oportuno ouvir, em audiência pública, não só as entidades que requereram a admissão no processo como 'amicus curiae',(...) como também as seguintes entidades: Federação Brasileira de Ginecologia e Obstetrícia, Sociedade Brasileira de Genética Clínica, Sociedade Brasileira de Medicina Fetal, Conselho Federal de Medicina, Rede Nacional Feminista de Saúde, Direitos Sociais e Direitos Representativos,
}

\footnotetext{
502 Stephen C. Yeazell, Intervention and the idea of litigation: a commentary on the Los Angeles School case, p. 245.

503 Joaquim Falcão, Justiça Social e Justiça Legal: Conflitos de Propriedade no Recife.
} 
Escola de Gente, Igreja Universal, Instituto de Biotécnica, Direitos Humanos e Gênero (...) Deputado Federal José Aristodemo Pinotti, (...). 3. Ao plenário, para designação de data, visando à apreciação da questão de ordem relativa à admissibilidade da ADPF."

É claro que essa audiência que o Ministro sentiu necessidade de convocar é concebida como uma "assembléia". Dela participariam deputados, órgãos religiosos, especialistas e ativistas de direitos humanos para fornecerem, cada qual, seus respectivos conhecimentos e posições. Sem a consideração de todos esses interesses ficaria, simplesmente, muito difícil decidir uma questão socialmente tão delicada.

Esse mesmo caso demonstra as razões que têm motivado a flexibilização referida acima na estrutura parte-controlada do processo tradicional. Mostra, por uma lado, que o “interesse" no assunto não é unidirecionado e não é disponível pelo autor (no caso, a Confederação Nacional dos Trabalhadores em Saúde). Isso significa, desde logo, que o pleito formulado pelo autor pode não corresponder aos desejos de disposição do bem comum (aqui, a liberdade) atinentes a todos os atores envolvidos no conflito ${ }^{504}$. Muito claramente, não correspondem, no caso, aos interesses da igreja. Mas significa também algo além disso. A análise acurada desse caso demonstra como os autores das ações de repercussão coletiva raramente se apresentam como reprodutores fiéis dos conflitos sociais que eles trazem a juízo. Ao revés, eles tentarão sempre reformatar esses conflitos de sorte a tornar seus objetivos mais palatáveis pela corte. Neste caso, é de todo evidente que a discussão gira em torno do "direito" ao aborto, isto é, da liberdade que se deve ou não atribuir às mulheres para disporem do próprio corpo e interromperem uma gestação indesejada. Está em questão a revisão das regras estabelecidas na década de 1940 pelo Código Penal. Contudo, não é isso que diz o autor neste caso. Para a Confederação Nacional dos Trabalhadores em Saúde, o caso de anencefalia sequer qualificaria aborto, representando apenas uma "antecipação terapêutica do parto". O eufemismo, por um lado, torna a discussão menos sensível por parte da corte. Por outro, contudo, procura situar o conflito em um lugar que não lhe é, se considerada sua dinâmica social, próprio.

Esses problemas relativos à estrutura e modos de representação de conflitos policêntricos têm levado os juízes nacionais a, sobretudo no caso de ações coletivas,

\footnotetext{
${ }^{504}$ Muitas vezes, não corresponde sequer às posições majoritárias do próprio grupo sócio-cultural que em princípio estaria representando. Uma análise nesse sentido, centrada nos casos de dessegregação de escolas americanas, é feita em Derick A. Bell Jr., Serving Two Masters: Integration Ideals and Client Interests in School Desegregation Litigation, p. 470-516.
} 
flexibilizarem a rigidez das regras relativas à estabilização da demanda (fixação dos termos em que se dará o litígio) e adstrição (delimitação da sentença aos termos exatos do pedido fornecido pelo autor e dos motivos apresentados por ele para justificar esse pedido). Não por acaso, está hoje em curso de elaboração, como dito, um anteprojeto de reforma do processo coletivo brasileiro, o qual pretende adotar, nesse tema, solução semelhante àquela prevista pelo "Código Modelo de Processos Coletivos para Ibero-América", elaborado pelo Instituto Ibero-Americano de Direito Processual. Nos termos do artigo 10 desse Código Modelo, "[n]as ações coletivas, o pedido e a causa de pedir serão interpretados extensivamente", sendo que "o juiz permitirá a alteração do objeto do processo a qualquer tempo e em qualquer grau de jurisdição, desde que seja realizada de boa-fé, não represente prejuízo injustificado para a parte contrária e o contraditório seja preservado".

Essa proposição soa, sem dúvida, como uma revolução no processo civil tal como forjado pela tradição liberal. No entanto, se lembrarmos que ela se aplica, sobretudo, ao modelo da gestão de interesses, e que, no Brasil, não há contencioso administrativo, esse estranhamento reduz bastante sua intensidade.

O direito português, por exemplo, no âmbito da tutela de interesses (tutela por parte do contencioso administrativo, em vista do regime dual ali vigente), possui regra de mesmo sentido que essa. Trata-se do artigo 56 do Código Português de Procedimento Administrativo, segundo o qual "[o]s órgãos administrativos, mesmo que o procedimento seja instaurado por iniciativa dos interessados, podem proceder às diligências que considerem convenientes para a instrução, ainda que sobre matérias não mencionadas nos requerimentos ou nas respostas dos interessados, e decidir coisa diferente ou mais ampla do que a pedida, quando o interesse público assim o exigir”.

É justa, portanto, a constatação de Molot, para quem o novo perfil de atuação do contencioso coletivo americano lembraria muito a própria ação administrativa de gestão de interesses. Segundo o autor, "as características do contencioso envolvendo ações coletivas, que o distinguem do contencioso tradicional e criam grande incerteza quanto ao papel dos juizes - sua confiança neles para monitorar a ação do representante em favor de seus representados, para pesar interesses mais que simplesmente aplicar regras, e que assim 
separam-no de seu papel tradicional de adjudicação - caracterizaram o processo administrativo por boa parte do século vinte." ${ }^{, 505}$

Como não se pode confiar no poder de disposição das próprias partes, é preciso haver uma intervenção judicial intensa na delimitação do objeto dos processos. Como a dinâmica dos conflitos exige intensas adaptações, é preciso que a crença na lei como elemento organizador do processo seja substituída por confiança no bom senso judicial para a especificação dos caminhos procedimentais a seguir.

Mas é preciso reconhecer que, apesar dessas transformações paulatinas, o juiz-herói brasileiro ainda enfrenta um problema importante no campo desses novos conflitos, agora ligado menos à regulação do processo judicial e mais à falta de condições de trabalho adequadas. Em que pese sua intensa capacidade de investigação probatória, ${ }^{506}$ nem sempre lhe estão disponíveis os recursos materiais necessários à obtenção de informações especializadas. Aliás, esse é um problema sentido não apenas por juízes mas também, sobretudo, pelos próprios promotores de justiça.

Em pesquisa realizada em 1996 com cerca de 20\% dos promotores e procuradores de justiça de 7 estados, mais 51 integrantes do Ministério Público Federal, estes apontaram as "dificuldades na realização de perícias", a "falta de apoio técnico a promotores e procuradores", as "dificuldades na obtenção de provas" e a "falta de especialização em problemas específicos (poluição, finanças públicas, taxa de juros, etc.)" como os quatro mais importantes obstáculos a uma adequada prestação jurisdicional na área dos direitos difusos, coletivos e individuais homogêneos. Em cada um desses itens, a soma das respostas "muito importante" e "importante" foi, respectivamente, de 92\%, 91\%, 88\% e $82 \%{ }^{507}$ Esse é um problema especialmente sério pois aponta também para um possível desequilíbrio de posições nas situações em que a tutela de interesses difusos envolver grandes corporações, capazes de mobilizar recursos vultosos para a demonstração de suas teses, o qual não poderá, pelas razões vistas acima, ser compensado por qualquer intervenção jurisdicional específica. ${ }^{508}$

\footnotetext{
505 V. Jonathan T. Molot. An Old Judicial Role for a New Litigation Era, p. 95.

506 V. José Roberto dos Santos Bedaque, Poderes Instrutórios do Juiz, passim.

${ }^{507}$ V. Maria Tereza Sadek. O Ministério Público e a Justiça no Brasil, p. 56.

${ }^{508}$ Em tese, os mecanismos de inversão dos ônus da prova deveriam servir para reequilibrar as posições das partes nessas situações. Contudo, eles se prestam mal a essa função, pois o problema é menos o de
} 
De implementação bem mais complicada e controversa que as modificações referentes aos critérios de admissão em juízo e à estrutura das decisões, esses temas abordados acima, embora não sujeitos a aprofundamento neste trabalho, remetem às transformações mais paulatinas e incipientes pelas quais vem passando o modo de ser do contencioso tradicional. As deficiências ligadas à acomodação da estrutura prospectiva, especializada e policêntrica dos novos conflitos ainda se mostram bastante presentes na realidade prática. Contudo, esse é, também, um dos pontos que parece reservar mais potencialidades de desenvolvimento futuro no campo da tutela de interesses difusos e coletivos.

\section{V}

\section{TEMPO E AUTORIDADE NA ESTRUTURA DAS DECISÕES}

O último conjunto de temas a tratar é o da evolução encontrada no sistema de tutelas utilizado pelo direito nacional. Essa evolução caminhou, como visto, no sentido de acentuar duas formas específicas de proteção judicial: a tutela liminar, provisória e modificável, em suas mais diferentes formas, ${ }^{509} \mathrm{e}$ a tutela chamada especifica, consistente na expedição de ordens variadas cujo cumprimento pode ensejar medidas de busca e apreensão, intervenção e interdição em estabelecimentos, imposição de multas, desfazimento de obras e muitas outras providências semelhantes ${ }^{510}$. Combinadas, essas duas formas de tutela (diferentes da tutela tradicional tanto na estrutura quanto na temporalidade) dão a marca da atuação judicial nos dias presentes.

A prevalência das tutelas emergenciais, provisórias e ligadas a ordens de atuação e abstenção encontra larga correspondência no movimento que se seguiu à introdução da sructural reform litigation nos Estados Unidos, onde esse tipo de tutela recebe o nome de

responsabilizar a parte economicamente fraca pela ausência de prova sobre suas teses e mais, justamente, o de deixar a condução da fase instrutória nas mãos exclusivas da parte poderosa. A razão para tanto é mais que óbvia: "skillful orchestration of proof may obscure rather than clarify wat has actually happened" (Mirjan R. Damaška. The Faces of Justice and State Authoricy: A Comparative Approach to the Legal process, p. 122). Cf. tb. Mirjan R. Damaška. Adversary Presentation of Evidence and Factfinding Precision.

${ }^{509}$ V. a respeito José Roberto Bedaque, Tutela Cautelar... passim.

${ }^{510}$ V. idem, ibidem. V. tb., Kazuo Watanabe. Tutela antecipada e tutela especifica das obrigações de fazer e não fazer. 
injunction. ${ }^{511}$ Como aponta Fiss, "Brown deu à injunction uma proeminência especial. Os casos envolvendo a dessegregação de escolas públicas formaram um dos principais campos de atuação dos tribunais no período compreendido entre 1954-74, e nesses casos o modo típico de tutela era a injunction., 512

À provisoriedade desse tipo de tutela corresponde, como apontava Ost, a própria "função criadora do interesse". Como dizia ele em trecho já referido, "o interesse se inscreve na temporalidade do porvir" e, por isso, "participa igualmente de uma temporalidade aleatória que ao mesmo tempo desestabiliza situações pré-estabelecidas e assegura à sua regulamentação uma mutabilidade que lhe permite permanecer constantemente em consonância com as circunstâncias." Daí a "a natureza precária do tempo do interesse: o fato de que ele é freqüentemente invocado em situações de urgência (...) e, por outro lado, o fato de que o regramento que lhe dispensamos traz muito freqüentemente a marca do provisório."

De outro lado, a necessidade de "testar soluções" é igualmente contemplada pelo caráter provisório dessa espécie de tutela. Se insuficientes, as medidas de apoio que a amparam podem ser intensificadas, alteradas ou mesmo inteiramente modificadas. Do ponto de vista material, se "as circunstâncias de fato mudarem", também poderá ser modificada a própria ordem judicial expedida ${ }^{514}$, o que dificilmente seria aceito pelo processo tradicional no campo das sentenças, sobretudo daquelas tornadas imutáveis pela coisa julgada.

Assim, o uso intenso desse tipo de medida parece poder ser interpretado, novamente, como uma resposta às necessidades apresentadas pela justiça dinâmica, resposta essa que não é desacompanhada, obviamente, de desarranjos estruturais. O mais importante deles consiste no fato dessas tutelas seres desenhadas para funcionar apenas até o momento do julgamento final, quando deveriam, em princípio, ser substituídas por uma decisão capaz de tornar-se imodificável. A ocorrência, ao final, desse tipo de decisão poderia colocar em jogo a potencialidade dinâmica das soluções provisórias anteriores. Não obstante, isso acaba raras vezes apresentando-se como um problema real, pois: (i) em

\footnotetext{
${ }^{511}$ V. José Roberto dos Santos Bedaque, Tutela Cautelar..., 58 e ss. e Carlos Alberto de Salles, Execução Judicial em Matéria Ambiental, p. 161-222.

512 Cf. Owen M. Fiss. The Civil Rights Injunction, p. 4

513 Idem, ibidem.

${ }^{514}$ V. José Roberto dos Santos Bedaque, Tutela Cautelar..., p. 151.
} 
muitos casos a atuação judicial não tem a função de resolver definitivamente o conflito, mas apenas a de rearanjar as forças que dele participam e recolocar os termos em que as soluções exógenas poderão operar ${ }^{515}$ e (ii) a lentidão da justiça brasileira é de tal forma grave que muitas vezes a resposta "definitiva" pode demorar mais de década a surgir, o que acaba significando que a regulamentação do conflito, enquanto ele é ainda presente, dá-se, na verdade, pelas formas provisórias de tutela, nas quais o próprio mérito das questões é frequentemente analisado em profundidade.

Mas mesmo as formas definitivas de tutela parecem estar passando por mudanças importantes. Elas também incorporam, por exemplo, a técnica da tutela específica, o que significa que, se permanecerão em princípio imutáveis no que diz respeito à solução material que deram ao conflito, poderão, em contrapartida, ter alterados os termos em que mandam atuar essa solução material, modificando os tipos de ordem correspondentes (ordens de ação ou abstenção), rearranjando as condições específicas de cumprimento ou adotando outras medidas. Além disso, a implementação dessas ordens cada vez mais tornase um prolongamento do próprio momento da decisão, exigindo atuação judicial contínua e constante. ${ }^{516}$ Finalmente, o próprio caráter absoluto em que tradicionalmente se colocou a imutabilidade dessas decisões finais tem conhecido importante contestação no âmbito da dogmática, debaixo das idéias de relativização da coisa julgada. ${ }^{517}$ Ainda que desorganizada e não intencionalmente, essas transformações podem ser interpretadas, novamente, como respostas aos problemas instrumentais colocados pelos novos conflitos de direito público, mais e mais submetidos à máquina judiciária.

No campo da tutela de interesses coletivos, essas modificações ficam ainda mais claras. Tomando-se os resultados das pesquisas empíricas disponíveis, é possível constatar que a solicitação de medidas liminares ocorre em quase 100\% dos casos, havendo, ainda, um grau bastante expressivo de concessão dos pedidos correspondentes. Ademais, esses pedidos tendem, no mais das vezes, a assumir caráter injuntivo, e direcionam-se, na quase totalidade dos casos, à defesa de interesses difusos ou coletivos, mas não à de direitos individuais homogêneos (v., a propósito, a Tabela 05, acima).

\footnotetext{
515 Voltarei a tratar desse problema quando da conclusão do trabalho.

${ }^{516}$ Remeto o leitor, novamente, aos termos da Lei n. 11.232, de 22 dezembro de 2005, que acabou com o processo autônomo de execução de sentenças, seguindo tendência já presente em alterações anteriores do Código de Processo Civil.

517 V., a respeito, Cândido Rangel Dinamarco. Relativizar a coisa julgada material, p. 29/77. V. tb. Eduardo Talamini, Coisa Julgada e sua Revisão.
} 
Na pesquisa conduzida por Pinheiro Carneiro entre os anos de 1985 e $1996^{518}$, descobriu-se que em $79,3 \%$ dos casos o pedido formulado pelo demandante foi exclusivamente de caráter injuntivo, isto é, consistiu apenas na imposição de ordens de ação ou abstenção, isoladas ou cumuladas entre si, sem qualquer pedido de condenação em dinheiro. Pedidos exclusivamente voltados à condenação em dinheiro foram formulados em apenas 3,44\% dos casos. Isolados ou cumulados com pedidos de outra natureza, esses pedidos responderam, ao todo, por apenas $10,33 \%$ dos casos.

Houve requerimento de medida liminar em 91,95\% dos casos, sendo que a liminar foi concedida em $58,75 \%$ dos casos em que foi requerida. Entre os casos nos quais foi condedida a liminar, 63,82\% redundaram em sentenças de procedência, e 36,18\% em sentenças de improcedência.

As ações foram julgadas procedentes em 29,27\% dos casos examinados em que houve julgamento definitivo. As ações julgadas parcialmente procedentes atingiram o percentual de $14,63 \%$ e os pedidos foram rejeitados integralmente em $9,75 \%$ dos casos. $\mathrm{O}$ que mais chama a atenção, contudo, são os casos em que não houve julgamento de mérito: representavam, naquela pesquisa, em nada menos que $43,90 \%$ do universo analisado.

Na pesquisa subseqüente realizada por Vianna e Burgos, ${ }^{519}$ levada a cabo entre os anos de 1996 e 2001, essas constatações são de novo confirmadas. A pesquisa não aferiu que tipo de tutela era objeto de requerimento em cada caso, mas constatou que a justiça tem se sentido bastante à vontade para conceder os pedidos de ordem liminar que lhe são endereçados. Esses pedidos teriam sido concedidos total ou parcialmente em 78,9\% dos casos, com uma dispersão bastante desigual das chances de sucesso em favor dos órgãos públicos e do Ministério Público. Respectivamente, as chances de sucesso desses atores (deferimento total ou parcial das ordens liminares requeridas) alcançou os percentuais de $93,3 \%$ e $88,1 \%$. As chances de obtenção de liminar por parte dos órgãos da sociedade civil foram expressivamente menores, mas atingiram, ainda assim, importantes $50 \%{ }^{520}$

É claro que essas mudanças são uma resposta, também, à crônica incapacidade da justiça brasileira de instrumentalizar a cobrança de créditos. Assim, a transição da

\footnotetext{
${ }^{518}$ Cf. Paulo Cezar Pinheiro Carneiro, Acesso à Justiça.

${ }^{519}$ Cf. Luiz Werneck Vianna e Marcelo Burgos. Revolução processual do direito e democracia progressiva.

${ }^{520}$ Idem, p. 482.
} 
reparação por danos passados para a intervenção direta e prospectiva na realidade é uma resposta não apenas à natureza dos novos conflitos sociais, mas também ao aspecto de decadência da justiça civil referido acima. É decorrência parcial da ineficiência da máquina judiciária, que cada vez menos é capaz de transformar direitos de crédito em dinheiro posto no bolso do credor.

Sem dúvida, essa é uma explicação concorrente poderosa para o que se observa na realidade, capaz de dar conta, por exemplo, do baixíssimo número de ações voltadas à persecução de direitos individuais homogêneos (as class actions for damages, como refere Ada Pellegrini Grinover ${ }^{521}$ ). No sistema brasileiro, essas ações produzem uma condenação genérica que pode ser, depois, executada individualmente pelos prejudicados, mediante prova individual do dano e de sua extensão. As dificuldades envolvidas nesse processo posterior de liquidação dos danos e cobrança específica dos valores devidos fazem com que tal espécie de ações torne-se cada vez mais rara.

Há, contudo, no contexto das mudanças em exame, um outro ponto relevante a tratar, ainda inserido no campo da "estrutura das decisões". Trata-se da redefinição do próprio papel reservado ao contencioso civil e ao órgão jurisdicional, cada vez menos diretivo e cada vez mais de intermediação, de estímulo à obtenção de soluções de compromisso negociadas pelas próprias partes.

A tendência no sentido de enfatizar esse papel mediador do órgão jurisdicional tem sido identificada de forma bastante uniforme pela literatura nacional ${ }^{522}$ e estrangeira ${ }^{523}$. Nesse contexto, a sentença como ato final do procedimento vem cada vez mais cedendo espaço ao acordo. Isso, igualmente, parece ser uma resposta ao novo modelo emergente de gestão de interesses, cujo modo de administração, como visto, coincide com o compromisso, com a negociação, não com a adjudicação. Aliás, ainda em consonância com

${ }^{521}$ Cf. Ada Pellegrini Grinover, Da Class Action for Damages à Ação de Classe Brasileira: os Requisitos de Admissibilidade.

${ }^{522}$ V., por exemplo, a edição especial dos Cadernos do Centro de Estudos Judiciários do Conselho da Justiça Federal, vol. 22., dedicada inteiramente à mediação. V., entre os artigos ali publicados, especialmente o de Kazuo Watanabe (Modalidade de Mediação. Cadernos do CEJ, vol. 22, p. 42-50

${ }^{523}$ V., v.g, Roberto Omar Berizonce. Los medios alternativos de solucion de conflictos: bases para su implentacion; Marc Galanter. The Emergence of the Judge as a Mediator in Civil Cases e Owen M. Fiss, Against Settlement. 
essa tendência, é de se frisar a existência de Projeto de Lei em curso perante o Congresso Nacional, atinente à mediação. ${ }^{524}$

Sem prejuízo desse caminho em direção a formas de autocomposição dos conflitos, há, no direito nacional, dois importantes obstáculos à consolidação de transformações nesse sentido, ambos culturais. $\mathrm{O}$ primeiro diz respeito ao sentimento possessivo que os órgão judiciários demonstram em relação ao monopólio da atividade de solução de controvérsias. O segundo liga-se à noção de que certos interesses, por dizerem respeito àquela fugidia categoria do interesse público, não seriam transacionáveis, resultando, assim, indisponíveis.

O primeiro obstáculo é demonstrado por aquela recente pesquisa levada a efeito por Maria Teresa Sadek, sob encomenda da Associação dos Magistrados Brasileiros. ${ }^{525}$ Os dados ali colhidos demonstravam que $89,8 \%$ dos magistrados entrevistados acreditavam na necessidade de manter-se o monopólio da jurisdição concentrado nas mãos do Poder Judiciário. Outros 78,3\% compreendiam que todas as formas de solução de controvérsias deveriam ser subordinadas ao Poder Judiciário ${ }^{526}$. Apesar de imobilizados por um volume de litígios que não conseguem vencer, os magistrados parecem compreender que mesmo essa sua atividade de prestação de serviços, relacionada à solução de conflitos privados, envolve o exercício intenso de uma dada forma de poder, da qual não querem abdicar.

O segundo obstáculo remete, novamente, ao problema da falsa unidade do "interesse público" e da identificação dos interesses difusos como interesses de ninguém, interesses da "coletividade", assim abstratamente considerada. Por força da reunião dessas idéias constrói-se a noção de que os interesses sobre bens comuns somente podem ter solução adjudicada, uma vez que a transação significaria exercício indevido de disposição por aqueles que não são os donos do interesse, mas apenas seus representantes. Ademais, como a tutela desses interesses é normalmente feita à luz do conceito de interesse público, o qual, por nova ficção, seria possível sempre de ser apreendido por processo cognitivo, assimilando-se à única solução correta previamente desejada pela lei, a transação

\footnotetext{
${ }^{524}$ Projeto de Lei n. 94/02, de autoria da Deputada Zulaiê Cobra.

525 Maria Tereza Sadek (coord.), Pesquisa AMB 2005.

526 Idem, p. 62.
} 
representaria sempre, nesse contexto, violação à lei, ainda que esta lei seja tão genérica a ponto de simplesmente não trazer, a priori, qualquer solução explícita para o conflito. ${ }^{527}$

O já referido Anteprojeto de Código Brasileiro de Processos Coletivos procura tratar dessa questão em seu artigo 23, que prevê, também em sede de processo coletivo, a possibilidade de sugerirem-se às partes formas alternativas de solução do conflito, tais como "a mediação, a arbitragem e a avaliação neutra de terceiro." ${ }^{\text {"528 }} \mathrm{O}$ anteprojeto dispõe ainda que, "[p]reservada a indisponibilidade do bem jurídico coletivo, as partes poderão transigir sobre o modo de cumprimento da obrigação". Esse é um passo importante mas parece ainda não resolver o cerne do problema pois, no mais das vezes, o que se questiona é a "extensão da obrigação", não o modo de seu cumprimento. Isso, recorde-se mais uma vez, em um contexto no qual as posições de vantagem não estão dadas previamente pela lei (a lei se expressa, recorde-se, por meio de termos vagos e conceitos abstratos), sendo, ao revés, construídas e delimitadas no curso do próprio processo judicial.

Confrontada com essas tradições jurídicas, a realidade parece ir encontrando, pouco a pouco, suas válvulas de escape. Assim, se a tradição faz com que não seja possível transigir em juízo, a transação passa a ocorrer fora das salas de sessão dos tribunais.

Isso ocorre porque, teoricamente, os pedidos formulados pelos representantes dos interesses difusos litigados deveriam corresponder, de acordo com a tradição, aos ditames daquele interesse público unívoco e pré-identificado. Se assim é, qualquer concessão em relação a esses pedidos já feitos passaria a ser interpretada como concessão aos limites rígidos do interesse público, o que no caso do Ministério Público poderia implicar até mesmo falta disciplinar. Dessa sorte, o Ministério Público, por exemplo, passa a tentar implementar seus acordos antes de ir a justiça, quando ainda não foi formulado nenhum pedido específico e a instituição ainda não se comprometeu, portanto, com nenhuma interpretação concreta daquilo que seria, no caso, "o" interesse público. Livre de uma pretensão já deduzida em juízo, é possível à instituição afirmar, nesses casos de

\footnotetext{
527 V. sobre esse tema, Eros R. Grau, Direito Posto e Direito Pressuposto, passim.

${ }^{528}$ Esta última categoria, a da avaliação neutra de terceiros, remete à figura dos summary jury trials americanos. São processos não necessariamente vinculantes de solução de controvérsias, por meio dos quais um certo litígio é apresentado, ao longo de um dia, a um painel de jurados, que analisa os argumentos das partes e as provas sumariamente apresentadas para fornecer, então, seu "veredito". Todo o processo é conduzido perante um juiz togado, e a submissão a ele pode ser ordenada às partes independentemente de sua vontade, hipótese em que o veredito não poderá nunca ter caráter vinculante. A idéia é que o próprio exercício de apresentação oral do caso estimule o acordo, e que o veredito sumário, posto que não vinculante, possa fornecer um critério inicial para a auto-composição.
} 
conciliação anterior ao processo, por meio de nova ficção, que o acordo realizado sempre correspondeu, efetivamente, "ao" interesse público, o que quer que isso queria, concretamente, dizer. A solução de compromisso, claramente negociada, ocorre portanto do mesmo modo, mas perde-se aquela que poderia ser a principal razão de ser do processo judicial nessas hipótese: fiscalizar os termos em que se dá essa transação, cuidando, ainda, para que ela leve em conta todos os multifacetados, dispersos e contraditórios interesses nela envolvidos. ${ }^{529}$

Dessa forma, as interpretações tradicionais da noção de interesse público e indisponibilidade parecem não estar impedindo, no plano dos fatos, a realização de soluções de compromisso, mais flexíveis e em princípio mais adequadas à solução das controvérsias geradas por esse modelo de gestão de interesses. Essas interpretações impedem, apenas, que o processo de barganha respectivo seja submetido à inspeção judicial, perdendo, quando menos, em publicidade.

Esse processo de negociação é parte importante do contencioso de interesse público a que estou me referindo e, em muitos casos, consiste em solução mais facilmente implementável que a ação adjudicatória oficial. Exemplo recente disso consiste no acordo celebrado entre o Ministério Público do Estado de São Paulo e a Prefeitura do Município de São Paulo, que viabilizará a criação de 108.000 novas vagas nas escolas municipais e, afirmadamente, substituirá a solução adjudicada em 45 ações civis públicas propostas com finalidade semelhante. ${ }^{530}$

Mais uma vez, parecemos estar diante de mais um campo capaz de sofrer transformações profundas no futuro. A importância da transação para a tutela dos interesses difusos tem crescido e os mecanismos formais do processo judicial ainda não conseguem responder adequadamente às necessidades daí decorrentes. Não obstante, notam-se, mais uma vez, caminhos de mudança relativamente claros, explicáveis e

\footnotetext{
${ }^{529}$ No sistema americano de ações de classe a realização de acordos depende de intensa físcalização judicial sobre seus termos, que inclui, conforme os termos da Rule 23 (e), entre outras exigências, o seguinte: (i) notícia às pessoas afetadas pelo acordo quanto aos termos propostos para ele, (ii) realização de audiência para oitiva dos interessados, (iii) avaliação da adequação, justiça e razoabilidade do acordo, (iv) consideração das opiniões contrárias ao acordo. Outras exigências são feitas por meio de construção jurisprudencial. V., a respeito, Kevin Armstrong et al., Jeffrey Jackson et al. V. Board of School Directors of the City of Milwaukee (616 F.2nd 305 (7th Cir. 1980).

${ }^{530}$ V., a respeito, notícia publicada na edição de 4 de janeiro de 2006 do Jornal Diário de São Paulo (Promotoria faz acordo para criar mais vagas em escolas).
} 
impulsionados pelas necessidades peculiares dos conflitos sociais que são, mais e mais, levados às barras dos tribunais brasileiros.

\section{VI}

RACIONALIDADE, IRRACIONALIDADE E ISONOMIA:

CONCENTRAÇÃo DECISÓRIA E VINCULAÇÃO PELO PRECEDENTE NAS TENTATIVAS

RECENTES DE REFORMA

Que reações importantes essas modificações institucionais acabaram gerando? Em seu trabalho citado anteriormente, Botelho de Mesquita afirma que elas levaram os outros "dois poderes a, em defesa própria, se unirem contra o Judiciário."531 Segundo ele, isso seria confirmado pela edição de dispositivos legais como aqueles inseridos na Lei n. 9.099, de 26 de setembro de 1995 (art. 3o, §2), Lei n. 8.437, de 30 de junho de 1992, Lei n. 9.494, de 10 de setembro de 1997, ou na Medida Provisória n. 1.798, com primeira edição em 11 de fevereiro de 1999. Na visão do autor, "[e]ssas restrições todas têm um ponto em comum. Limitam a eficácia dos juízos sumários e restringem a discricionariedade dos juízes; exatamente o carro-chefe das reformas processuais posteriores à Constituição de 1988. Reforçam o princípio da legalidade e restauram as garantias do devido processo legal, embora apenas a favor do Poder Público". ${ }^{532}$ Pretendo, neste item final, dar conta de algumas dessas reações.

Discordando, neste ponto, da interpretação de Botelho de Mesquita, não me parece, em princípio, que elas possam ser tidas propriamente como tentativas de retorno ao paradigma liberal de contencioso civil $^{533}$. Nem que reforcem o "princípio da legalidade", entendido como interpretação rígida da regra de separação de poderes (quem julga não cria direito, por exemplo). Tampouco creio que essas respostas visem conscientemente a restaurar quaisquer garantias perdidas do devido processo legal. Ao contrário, parece-me

\footnotetext{
531 José Ignácio Botelho de Mesquita. As Novas Tendências..., p. 60.

532 Idem, ibidem.

533 Tentativas de retorno a um modelo de "direito autônomo", como diriam Nonet e Selznik (Law and Society in Transition.., passim), ou de reconstrução do papel institucional reservado ao Juiz Júpiter, como ponderaria Ost (Jupiter, Hércules, Hermes..., passim).
} 
que essas reações encerram, sobretudo, respostas de contenção $e$ respostas de racionalização à crescente atuação judicial no campo das políticas públicas. ${ }^{534}$

No primeiro grupo de respostas, concentram-se alterações legislativas destinadas a circunscrever o âmbito de incidência material das decisões judiciais, a impedir o tratamento coletivo de certos conflitos envolvendo o orçamento público e a limitar o poder de concessão de liminares contra o Estado. Mais do que fundadas em uma dada concepção liberal ou pós-liberal de direito e justiça, mais que respostas racionais aos desajustes instrumentais referidos nos itens anteriores, elas são formas de reação institucional, ações de bloqueio oriundas do Poder Executivo, explicáveis pelo simples fato desse poder ter sido atingido, preferencialmente, pela expansão do órgão jurisdicional. Até por isso são respostas que não se originam no processo parlamentar regular mas sim em Medidas Provisórias, o que redunda, posteriormente, em verdadeira censura parlamentar, consubstanciada na EC n. 32/01, que proibiu o Poder Executivo de legislar sobre o processo civil ou penal através desse tipo de instrumento legislativo. ${ }^{535}$ Volto a tratar destas respostas logo adiante neste mesmo item.

No segundo grupo, parece-me que se reúnem, ao contrário, construções jurisprudenciais e outras tantas alterações legislativas destinadas a racionalizar a ação judiciária, sobretudo naquelas matérias em que, por uma razão ou por outra, as decisões extrapolam em seus efeitos o âmbito estrito das partes, espalhando efeitos redistributivos mais ou menos desorganizados por toda a sociedade. Também retomarei estas respostas adiante

Polêmica, a atribuição de efeito vinculante às súmulas do Supremo Tribunal Federal, objeto de recente reforma constitucional, ${ }^{536}$ poderia talvez ser considerada um ponto de intersecção entre as duas categorias que referi acima: é enxergada, alternativamente, ora como mecanismo de contenção, ora de racionalização, conforme se

\footnotetext{
${ }^{534}$ Durante o regime de exceção, como já dito, esse tipo de ação de bloqueio assumiu formas mais autoritárias, como, por exemplo, a alteração temporária do número de integrantes do Supremo Tribunal Federal, com a simultânea indicação às novas vagas de ministros alinhados com as políticas do governo militar. No regime democrático, assumem essas formas "mais brandas", direcionando-se a restringir a capacidade material de ação do órgão judiciário.

${ }^{535}$ V., a propósito, a atual redação do artigo 62 , parágrafo $1^{\circ}$, inciso I, alínea "b" da Constituição Federal.

${ }^{536}$ Implementada por meio da EC n. 45/04.
} 
esteja tratando, respectivamente, dos discursos críticos ou simpáticos à sua adoção ${ }^{537}$. Sobre este tema serão feitas as considerações finais desta última parte do trabalho.

Retomando, assim, aquele grupo de respostas que referi como ações de bloqueio, destacam-se, em primeiro lugar, as próprias Leis n. 8.437/92 e Lei n. 9.494/97, referidas por Botelho de Mesquita.

A primeira proíbe a concessão de liminares que esgotem total ou parcialmente o objeto de ação proposta contra o poder público, condiciona a concessão de liminares contra o poder público à manifestação prévia deste em setenta e duas horas (sempre que possível) e estende a qualquer tipo de ação o mecanismo da suspensão de segurança, originalmente previsto (por lei de Castelo Branco ${ }^{538}$ ) apenas para os mandados de segurança, autorizando o "presidente do tribunal, ao qual couber o conhecimento do respectivo recurso" que suspenda a liminar concedida em juízo inferior, "em caso de manifesto interesse público ou de flagrante ilegitimidade, e para evitar grave lesão à ordem, à saúde, à segurança e à economia públicas". Essa lei foi editada sob o governo do então presidente Fernando Collor como resposta à intensa contestação judicial das medidas de exceção instituídas pelo chamado Plano Collor e por planos econômicos subseqüentes ${ }^{539}$.

A segunda (Lei n. 9.494/97) tem origem na Medida Provisória n. 1.570, de 27 de março de $1997^{540}$. Por seu intermédio são estendidas as regras da Lei n. 8.437/92 também à antecipação de tutela prevista nas reformas do Código de Processo Civil ocorridas em 1994. Além disso, é alterado o artigo 16 da Lei da Ação Civil Pública, para o fim de conter-se a eficácia das decisões dadas em ações coletivas, que ficaram restringidas aos

537 Como explicarei adiante, parece-me que tanto uma quanto a outra dessas leituras está, ao menos parcialmente, equivocada.

${ }^{538}$ Lei n. 4.348 de 26 de junho de 1964.

539 A bem da verdade, a Medida Provisória n. 198, de 26 de julho de 1990 (reedição da Medida Provisória n. 182, de 23 de abril de 1990), já havia proibido, "até 15 de setembro de 1992", a concessão de liminares contrárias às disposições estabelecidas na legislação de regência do Plano Collor, sobretudo ligadas ao desbloqueio dos saldos confiscados das cadernetas de poupança. Essa Medida Provisória foi depois convertida na Lei n. 8.076, de 23 de agosto de 1990.

${ }^{540}$ Para um apanhado das reações à edição dessa Medida Provisória, v. os seguintes artigos e notícias, publicados no Jornal Folha de São Paulo: "Caricatura jurídica" (artigo de Dalmo de Abreu Dallari, ed. de 25/04/97, Caderno 1, p. 3), "STF dá vitória a governo sobre liminares" (Silvana de Freitas, ed. de 17/04/97, Caderno 1, p. 15), "OAB pede que TJ não casse liminar contra privatização" (sobre a privatização do sistema Anhanguera-Bandeirantes) (Rodrigo Vergara, ed. de 10/04/97, Caderno 3, p. 11), "MP de março renova polêmica" (Ed. de 05/04/97, Caderno 3, p. 2), "A face neocollorida" (artigo de João Piza, ed. de 05/04/97, Caderno 3, p. 2), “Associação de juízes protesta contra MP” (Silvana de Freitas, ed. de 04/04/97, Caderno 1, p. 15). 
limites da competência territorial do órgão que as profere ${ }^{541}$. Novamente, essa ação legislativa é resposta a uma modalidade específica de ativismo judicial, desta vez identificada com a reação ao processo de privatizações em curso (incluindo as mais de 100 decisões liminares diferentes, dadas em todo o Brasil, que suspenderam o processo de privatização da Cia. Vale do Rio Doce ${ }^{542}$ ).

Ambas as leis são objeto de considerável alteração no ano de 2000, por meio de nova Medida Provisória (MP n. $1.984^{543}$ ). Por intermédio desta norma legal proíbe-se a concessão de liminares para compensação de créditos tributários ou previdenciários, fica instituída uma esfera adicional de recurso nos casos de suspensão de liminar, permitindo-se a imediata submissão de matérias ao Supremo Tribunal Federal ou ao Superior Tribunal de Justiça, admite-se a suspensão de várias liminares por meio de uma única decisão da corte superior, proíbem-se as ações civis públicas versando matéria tributária, contribuições previdenciárias, FGTS ou "outros fundos de natureza institucional cujos beneficiários podem ser individualmente determinados" e, finalmente, estabelecem-se novas restrições à eficácia das sentenças dadas em ações coletivas. ${ }^{544}$

541 A bem da verdade, a idéia de restringir a eficácia das sentenças coletivas aos limites da competência territorial do órgão que as profere antecede a própria MP 1.570/97, acima referida, derivando da jurisprudência formada sobre o artigo 16 da Lei n. 7.347/85 anteriormente ao próprio Código de Defesa do Consumidor, exemplificada pela decisão do Superior Tribunal de Justiça no Conflito de Competência n. 971-DF. E é justamente porque essa jurisprudência se altera após a edição do CDC, passando a reconhecer a eficácia erga omnes do julgado coletivo, em todo o território nacional, que o ExecutivoLegislador sente, sete anos depois, a necessidade de transportar o entendimento jurisprudencial original para a lei. Um panorama bastante completo sobre a evolução da jurisprudência nesse particular é oferecido por Ada Pellegrini Grinover, Código Brasileiro de Defesa do Consumidor Anotado pelos Autores do Anteprojeto, p. 845-6. Pouco tempo depois de editada, a Medida Provisória n. 1.570 de 26 de março de 1997, foi alvo de ação direta de inconstitucionalidade, em que se questionou, entre outras coisas, a validade da alteração empreendida no artigo 16 da Lei n. 7.347/85. Essa ação foi movida pelo Partido Liberal, com fundamento no princípio da separação de poderes. Em resposta ao pedido de liminar formulado, assim posicionou-se o Supremo Tribunal Federal: "SENTENÇA - EFICÁCIA - AÇÃO CIVIL PÚBLICA. Em princípio, não se tem relevância jurídica suficiente à concessão de liminar no que, mediante o artigo $3^{\circ}$ da Medida Provisória $n^{\circ} 1.570 / 97$, a eficácia erga omnes da sentença na ação civil pública fica restrita aos limites da competência territorial do órgão prolator." Como, depois da apreciação da liminar, a Medida Provisória foi reeditada, inclusive com modificação parcial de seu texto, o STF considerou a ADI em questão prejudicada, não tendo, por isso, avançado no julgamento de mérito.

${ }^{542}$ V. a propósito a edição de 02 de maio de 1997 do Jornal do Brasil, p. 13-14.

${ }^{543}$ Hoje Medida Provisória n. 2.180-35, de 24 de agosto de 2001, em vigor por força do artigo $2^{\circ}$ da EC n. 32 , de 11 de setembro de 2001.

${ }^{544}$ Essas várias providências foram sendo introduzidas sucessivamente ao longo das várias reedições da Medida Provisória n. 1.984. A previsão de recurso imediato aos presidentes do STJ e STF, por exemplo, nos casos de suspensão de liminar, foi introduzida pela MP 1.984-14, de janeiro de 2000. 
Mais uma vez, a edição dessas medidas consistiu em reação ao ativismo judicial empreendido contra o movimento de privatizações, tendo sido utilizada também como instrumento preventivo destinado a possibilitar a privatização subseqüente do Banespa. ${ }^{545}$

Parece claro, portanto, que o objetivo dessas alterações foi o de circunscrever o âmbito de incidência material das decisões judiciais, impedir o tratamento coletivo de certos conflitos envolvendo o orçamento público, limitar o poder de concessão de liminares contra o Estado e concentrar poder decisório nas esferas superiores do Poder Judiciário. Pode-se perguntar, no entanto, o seguinte: haveria, nessa nítida ação de bloqueio, alguma virtude do ponto de vista de racionalização da tutela jurisdicional de interesses políticos e sociais? Em outras palavras, seria possível extrair dela alguma tentativa de correção dos desajustes mencionados anteriormente, relacionados ao tratamento de conflitos distributivos por meio de regras feitas para corrigir erros de justiça retributiva? A resposta que tenderia a dar a essas questões seria em parte positiva, em parte negativa.

Há, como visto na segunda parte deste trabalho, um desejuste fundamental quando as decisões distributivas são tomadas com foco na singularidade dos casos individuais. Como anotavam Cass Sunstein et al., esse procedimento pode, em primeiro lugar, gerar conseqüências no plano coletivo indesejáveis mesmo a quem tomou a decisão individualmente considerada ${ }^{546}$. Focado no plano particular, o órgão judicial acaba não percebendo que sua decisão não pode ser universalizada e decide, assim, irracionalmente. De outro lado, parece ser preciso concordar com Cappelletti quando ele adverte em relação aos perigos de introduzir o sistema difuso de controle de constitucionalidade em países de tradição jurídica ligada à família da civil law, em que não existe a doutrina do stare decisis ou da vinculação pelo precedente. Segundo o autor, "a introdução, nos sistemas de civil law, do método 'americano' de controle, levaria à conseqüência de que uma mesma lei ou disposição de lei poderia não ser aplicada, porque julgada inconstitucional, por alguns juízes, enquanto poderia, ao invés, ser aplicada, porque não julgada em contraste com a

\footnotetext{
${ }^{545}$ V., a propósito, os seguintes artigos e notícias publicados no Jornal Folha de São Paulo: "Leilão do Banespa vai ser adiado pela terceira vez" (Ed. de 10/06/2000, Caderno B, p. 3), "1984" (artigo de Fabio Konder Comparato, ed. de 14/06/2000, Caderno A, p. 3), "FHC muda as regras do jogo" (ed. de 09/07/2000, Caderno A, p. 11), “Advogado-geral diz que regras da MP já são aceitas” (ed. de 09/07/2000, Caderno A, p. 11), "Governo cria regras que o favorecem em batalhas judiciais" (Silvana de Freitas, ed. de 09/07/2000, Caderno A, p. 11).

${ }^{546}$ V. Cass Sunstein et al., Predictably incoherent judgments, p. 1153.
} 
Constituição, por outros". Prosseguindo adiante com seu espanto diante dessa possibilidade, diz Cappelletti que "a conseqüência, extremamente perigosa, de tudo isto, poderia ser uma grave situação de conflito entre órgãos e de incerteza do direito, situação perniciosa quer para os indivíduos como para a coletividade e o Estado". 547

Essas considerações dizem respeito a um problema jurídico fundamental (talvez o primeiro dos problemas jurídicos): a necessidade de tratar igualmente aos iguais.

Esse postulado de tratamento isonômico é também um problema processual pois é o processo judicial, em seus arranjos instrumentais, que pode reduzir ou amplificar desigualdades no plano do direito. A advertência é de William Rubenstein, para quem a desigualdade torna-se um problema das estruturas processuais tanto quando elas se defrontam com litigantes desiguais, dotados de desequilibrada capacidade de apresentar suas teses, quanto nas hipóteses em que o próprio processo gera resultados desiguais para pessoas que deveriam estar na mesma situação. ${ }^{548}$ Isso pode ocorrer, por exemplo, "quando um conjunto de partes similares litiga de forma independente um determinado dano". 549 Assim, "[u]ma parte das escolhas relativas ao desenho dos procedimentos e das regras processuais, mais ou menos explicitamente, procura evitar esse tipo de disparidade de resultado". ${ }^{550}$ Um desses mecanismos consiste na concentração de certos poderes decisórios nas cortes superiores, que existem exatamente para essa finalidade (mecanismos de uniformização de jurisprudência, vinculação por precedentes e, eventualmente, avocação de causas). Outro consiste no processo coletivo. Nesse contexto, é possível dizer que as respostas legislativas ao ativismo judicial da década de 1990 foram no mínimo inconsistentes.

Se por um lado tentaram promover a concentração de certos poderes de decisão nas mãos dos tribunais superiores, por outro acabaram sabotando o processo coletivo, ao (i) minar sua racionalidade fundamental por meio da limitação territorial dos efeitos da sentença coletiva, e (ii) eliminar sua força racionalizadora dos litígios, impedindo, por exemplo, sua utilização em matéria tributária. ${ }^{551}$ Quando se considera que o sistema

\footnotetext{
547 Cf. Mauro Cappelletti, O controle de constitucionalidade das leis no direito comparado, p. 77-8.

548 William B. Rubenstein. The Concept of Equality in Civil Procedure, passim.

549 Idem, p. 1893.

${ }^{550}$ Idem, p. 1894.

551 A estratégia, aqui, é "dividir" para administrar eventuais prejuízos, ainda que essa divisão potencialize iniqüidades, espalhando-as para muito além da esfera das partes afetadas. Diferenças de tratamento
} 
processual brasileiro é particularmente avesso a mecanismos de uniformização de jurisprudência, esse quadro assume proporções em geral mais preocupantes.

O potencial virtuoso que pode haver nessas respostas legislativas (ou ao menos em parte delas) remete às respostas de racionalização que mencionei acima. Essas respostas tentam, de certa forma, contornar os problemas surgidos do tratamento singular de questões distributivas. Fazem isso por vários mecanismos, que procuram forçar a adoção de uma perspectiva coletiva nesses litígios. Esses mecanismos podem passar pela concentração das esferas decisórias, pela concentração de poder nas cortes superiores, pelo incremento dos mecanismos de uniformização da jurisprudência e reunião de processos e, finalmente, pela vinculação pelo precedente.

Exemplo relacionado ao incremento de mecanismos de reunião de processos semelhantes é dado pelas decisões do Superior Tribunal de Justiça nos casos mais agudos relacionados à privatização e a outros conflitos envolvendo serviços públicos. Um desses exemplos remete à própria privatização da Cia. Vale do Rio Doce ${ }^{552}$. Outro remete ao contencioso instaurado quando do reajuste de tarifas de telefonia em 2002, já referido

tributário, por exemplo, quando criadas judicialmente, podem consistir em barreiras importantíssimas à competição, provocando desajustes em todo o mercado.

552 Superior Tribunal de Justiça. CC 9686 / DF. Primeira Sessão. Relator Ministro Demócrito Reinaldo. Confira-se a ementa desse julgamento: "Conflito de competência. Ações populares com o mesmo objetivo e fundamentos jurídicos iguais ou assemelhados. Conexão manifesta. Fixação da competência pelo principio da prevenção (arts. 106 e 219 do CPC). - ações populares aforadas perante juízes com a mesma competência territorial, visando o mesmo objetivo (a suspensão ou anulação do leilão da empresa vale do rio doce) e com fundamentos jurídicos idênticos ou assemelhados são conexas (art. 5., par. 3. Da lei 4.717/1965), devendo ser processadas e julgadas pelo mesmo juiz, fixando-se a competência pelo critério da prevenção. - o juízo da ação popular é universal. A propositura da primeira ação previne a jurisdição do juízo para as subsequentemente intentadas contra as mesmas partes e sob a égide de iguais ou aproximados fundamentos. - para caracterizar a conexão (CPC, arts. 103, 106), na forma em que esta definida em lei, não é necessário que se cuide de causas idênticas (quanto aos fundamentos e ao objeto); basta que as ações sejam análogas, semelhantes, visto como o escopo da junção das demandas para um único julgamento e a mera possibilidade da superveniência de julgamentos discrepantes, com prejuízos para o conceito do judiciário, como instituição. - o malefício das decisões contraditórias sobre a mesma relação de direitos consubstancia a espinha dorsal da construção doutrinaria inspiradora do principio do "simultaneus processus" a que se reduz a criação do "forum connexitatis materialis". O acatamento e o respeito as decisões da justiça constituem o alicerce do poder judiciário que se desprestigiaria na medida em que dois ou mais juizes proferissem decisões conflitantes sobre a mesma relação jurídica ou sobre o mesmo objeto da prestação jurisdicional. - A configuração do instituto da conexão não exige perfeita identidade entre as demandas, senão que, entre elas, preexista um liame que as torne passiveis de decisões unificadas. - Conflito de competência que se julga procedente, declarando-se competente para o processo e julgamento das ações populares referenciadas, o juízo da 4a. Vara federal da seção judiciária do para, para o qual devem ser remetidas, ficando, parcialmente, mantida a liminar, prejudicado o julgamento dos agravo regimentais, contra o voto do Min. Ari Pargendler que, dele não conhecia”. 
anteriormente. ${ }^{553}$ Em ambos os casos, nota-se a o movimento de racionalização da tutela coletiva, já mencionado acima, que busca concentrar as decisões sobre uma mesma política para evitar, assim, conflitos e irracionalidades.

A regulamentação da Argüição de Descumprimento de Preceito Fundamental, sobretudo após a interpretação que lhe deu o plenário do Supremo Tribunal Federal no julgamento da ADPF n. 54 (o caso envolvendo a antecipação terapêutica do parto em hipóteses de anencefalia fetal) consiste em outro exemplo desse mesmo movimento. Quisse viabilizar o uso desse instrumento para uniformizar o entendimento dos tribunais acerca de certas questões constitucionais controvertidas, envolvendo direitos fundamentais, o que colabora, novamente, para o incremento dos níveis de isonomia permitidos pelo sistema jurídico.

Outra importante reação em direção à correção dos desajustes instrumentais gerados pelo contencioso social está representada no conjunto da proposta já abordada antes, relativa ao Anteprojeto de Código Brasileiro de Processos Coletivos. Entre outras coisas, essa proposta prevê: (i) a possibilidade de reunião, inclusive de ofício, de demandas coletivas de qualquer espécie, quando houver "identidade do bem jurídico a ser protegido" (art. $5^{\circ}$ ), (ii) a possibilidade de "suspensão de processos individuais em que se postule a tutela de interesses ou direitos individuais referidos a relação jurídica substancial de caráter incindível, pela sua própria natureza ou por força de lei, a cujo respeito as questões devam ser decididas de modo uniforme e globalmente, quando houver sido ajuizada demanda coletiva versando sobre o mesmo bem jurídico" (art. $6^{\circ}$ ), (iii) a comunicação judicial do Ministério Público acerca da existência de litígios repetitivos, para que ele (ou outros legitimados) ingressem com ação coletiva (art. $7^{\circ}$ ), (iv) a eficácia nacional das sentenças

553 Superior Tribunal de Justiça. CC 39590 / RJ. Primeira Sessão. Relator Ministro Castro Meira. Veja-se a ementa: "Conflito de competência. Concessionárias de telefonia. Anatel. Aumento de tarifas. Competência da Justiça Federal. Lei 7.437/85. 1. Recomendável a reunião das mais de vinte ações que combatiam o aumento de tarifas autorizado pela ANATEL às operadoras de telefonia a fim de que fosse preservada a segurança jurídica nas relações de consumo do setor, em face da conexão. 2. A competência para julgamento é da Justiça Federal, nos termos do art. 109, I, da Carta Magna, por cuidar-se de causa em que entidade autárquica, como é o caso, integra o pólo passivo da relação processual. 3. Em seu art. 90, o Código de Defesa do Consumidor manda aplicar às ações coletivas nele previstas as normas do Código de Processo Civil e da Ação Civil Pública (Lei no 7.437/85). 4. A prevenção, em se tratando de ação civil pública, é determinada pela propositura da ação, consoante o art. 2o, parágrafo único, da Lei 7.437/85. Deve-se reconhecer a precedência do juízo onde foi proposta a primeira ação coletiva, ainda que tenha declarado extinto o feito, sem irresignação das partes interessadas, se tal decisão foi submetida ao duplo grau de jurisdição. 5. Conflito de competência conhecido para declarar a competência do Juízo da 2a Vara Federal do Distrito Federal.". 
(art. 12), (v) a competência dos juízos localizados no Distrito Federal, para os danos de âmbito nacional ou interestadual que compreendam mais de 3 (três) Estados, etc.

Essas alterações caminham no sentido de forçar a análise dos litígios de direito público sob o prisma coletivo, o que torna mais nítido, como visto acima, seu aspecto distributivo, reduzindo-se, em algum grau, certas iniqüidades e irracionalidades hoje abundantes.

Que dizer, então, da atribuição de efeito vinculante às súmulas do Supremo Tribunal Federal, instituída pela EC n. 45/04? Seria um exemplo de reação racionalizadora, de ação de bloqueio, ou um misto de ambas as coisas?

No contexto da completa desestruturação do papel racionalizador do direito empreendido pelo STF, desestruturação essa empreendida pela própria Constituição Federal, a proposta parece não responder nem a uma nem a outra dessas tendências. Não é instrumento de contenção, pois incide apenas sobre as súmulas do Tribunal, que reúnem matérias já exaustivamente julgadas e com jurisprudência relativamente pacificada. Analisadas concretamente as súmulas que o STF já produziu até hoje, boa parte refere-se a temas processuais. As demais veiculam orientações cujo respeito dificilmente atacaria, ou conteria, ativismos judiciais de qualquer forma. Estes são produzidos pela interpretação de textos abertos, cujo sentido, para todas as suas possíveis aplicações, jamais poderia ser dado pelo STF em súmula de sua jurisprudência dominante. Não sendo uma resposta de reação, a atribuição desse mesmo efeito vinculante também não parece ter um efeito racionalizador sobre o contencioso de ordem social, pelos mesmos motivos referidos acima e por um outro adicional: a súmula somente é produzida depois que um universo enorme de decisões é produzido, depois que muitas decisões conflitantes se tornam definitivas, e, uma vez que são editadas, tendem a ser respeitadas no âmbito do poder judiciário, com ou sem efeito vinculante formal.

A que necessidades essa providência vem, então, atender? Sobretudo, aos paradoxos de um Estado que insiste em apostar na auto-desinstitucionalização como estratégia de sobrevivência.

Como sabido, a atribuição de efeito vinculante à jurisprudência do Supremo Tribunal Federal fez-se necessária sobretudo porque a própria administração pública não 
costuma submeter-se aos entendimentos pacificados por esse tribunal. Sua ação como super-litigante, como litigante experiente e capaz de usar a máquina burocrática do judiciário em seu favor ${ }^{54}$ gera a maior parte dos litígios em curso perante esse mesmo tribunal. À guisa de exemplo, basta mencionar que, até fevereiro deste ano de 2003, encontravam-se pendentes de julgamento no Supremo Tribunal Federal mais de 33 mil recursos interpostos pela Caixa Econômica Federal, tendo por objeto ações relativas à correção do saldo do FGTS durante os planos Bresser, Verão, Collor I e II. Todos eles versando matérias idênticas e que já haviam sido objeto de decisão pacífica por parte do STF. $^{555}$

Na Emenda Constitucional n. 45, a modificação mais instigante parece ser, por isso, de outra ordem. Diz respeito à "relevância geral" como requisito de admissibilidade de recursos extraordinários perante o Supremo Tribunal Federal. Em outras palavras, diz com a capacidade que o órgão terá, ou não terá, de escolher suas pautas, selecionando os conflitos que irá e aqueles que não irá resolver, no âmbito do controle difuso de constitucionalidade.

Essa mudança ainda depende de regulamentação legal e, para dizer o mínimo, não foi feliz o desenho traçado pela reforma para o novo artigo 102 da Constituição. ${ }^{556}$ Mas certamente valerá a pena observar a interpretação e regramento final que se acabará dando ao novo dispositivo. Essa interpretação indicará, talvez, o caminho futuro que a superjustiça brasileira irá querer traçar para si. Uma justiça com potenciais democráticos importantes, mas que parece perdida entre objetivos hercúleos e recursos pífios. A justiça de um país que sonha em ter uma corte constitucional mas tem medo de uniformizar sua jurisprudência, invocar de modo consistente seus precedentes judiciários e organizar suas instituições.

${ }^{554}$ Ação de típico repeat player, na dicção de Marc Galanter (Cf. Marc Galanter. Why the 'Haves' Come Out Ahead: Speculations on the Limits of Legal Change).

${ }^{555}$ Em raro exemplo de bom senso no trato da administração pública, a CEF acabou firmando um acordo com o Supremo Tribunal Federal e com Advocacia Geral da União para extinção desse volume absurdo de recursos repetidos. Em decorrência desse acordo, já haviam sido extintos, por desistência homologada pelo STF, nada menos que 33.025 recursos, até fevereiro de 2003.

556 A Emenda Constitucional 45/04 incluiu a repercussão geral como requisito de admissibilidade do recurso extraordinário, mas condicionou sua apreciação à manifestação de dois terços dos membros do tribunal. Primeiro, é um evidentemente contra-senso exigir quorum qualificado para julgar um recurso desimportante. Depois, as dificuldades práticas decorrentes do procedimento sugerido pela reforma poderão, facilmente, tornar inoperante a modificação. 


\section{Conclusão}

As páginas anteriores procuraram traduzir uma abordagem específica do processo de judicialização da vida pública brasileira, realizada a partir de três diferentes perspectivas, que passo a sintetizar.

$\mathrm{Na}$ primeira parte, tentei localizar esse processo dentro de um contexto global de expansão do papel geral reservado aos órgãos judiciários, com particularidades importantes próprias às experiências americana, européia, latino-americana e brasileira. Essa tentativa foi empreendida sobretudo a partir de certas análises externas ao fenômeno jurídico, que privilegiam, por isso, condicionantes como (i) o desenho de arranjos institucionais, (ii) o desempenho das instituições representativas, (iii) a credibilidade pública dessas instituições, (iv) as estratégias de ação de partidos políticos e grupos de pressão em geral, (v) a identificação de certos vácuos no exercício do poder, etc. Foram descritas as críticas fundamentais (de legitimidade e capacidade instrumental) dirigidas a esse processo de modificação institucional. Foi referido ainda como acresce, em contextos de subdesenvolvimento econômico, uma crítica adicional, de caráter institucional, ligada à necessidade de construção de ambientes jurídicos estáveis, previsíveis e voltados à garantia de direitos de propriedade, como pré-requisito ao desenvolvimento. Dentre essas diferentes críticas, a de capacidade instrumental foi escolhida como objeto primordial das análises subseqüentes.

A segunda parte do trabalho coincidiu, por isso, com uma tentativa de dissecção da crítica instrumental (e, reflexamente, de recompreensão do processo de judicialização a partir de suas condicionantes internas ao direito). O objetivo primordial dessa análise, feita na segunda parte do texto, foi o de revelar as relações existentes entre (i) o modelo de justiça utilizado pela crítica instrumental como paradigma analítico e (ii) um certo modelo 
de direito, que tentei identificar como um direito de racionalidade formal, ${ }^{557}$ de viés “autônomo", ${ }^{558}$ voltado para a operação de mecanismos retributivos ${ }^{559}$ de justiça e baseado na proteção de direitos individuais ${ }^{560}$. Procurei mostrar como o contexto em que operava esse direito modificou-se substancialmente a partir da segunda metade do século XX, em direção a um modelo jurídico de racionalidade substancial, sensível a problemas e necessidades político-sociais, voltado também à operação de mecanismos distributivos de justiça e baseado na gestão de interesses, muitas vezes difusos no corpo social. Por isso, identifica-se, sobretudo na experiência americana das década de 1960 e 1970, a emergência de um novo modelo de contencioso civil, ligado aos litígios de direito público, à gestão de interesses difusos e à intervenção judicial em domínios de política pública, com características peculiares em relação àquele modelo liberal típico, utilizado como ponto de partida para a crítica instrumental.

$\mathrm{Na}$ terceira e última parte do texto a perspectiva de análise voltou-se especificamente para a experiência brasileira. Foram explorados os principais fatores que levaram a importantes alterações institucionais na Justiça e no processo judicial a partir da década de 1990, fazendo nascer um modelo brasileiro de juiz-herói. Esse modelo tem características individualizantes acentuadas, entre as quais se pode destacar a necessidade de convivência com um contexto material de sobrecarga de trabalho e paralisia administrativa, a existência do Ministério Público independente como ator social relevante e redutor dos custos de organização coletiva, um modelo semi-público de gestão de interesses difusos e um contexto institucional cultural e historicamente avesso à concentração de poderes decisórios e à uniformização de jurisprudência. Sem prejuízo dessas características, aduz-se nessa parte do trabalho que a transição do direito brasileiro para um estágio pós-liberal também foi acompanhada de modificações na estrutura do processo judicial semelhantes àquelas ocorridas na experiência americana anterior, o que se pode tanto explicar quanto interpretar a partir das dinâmicas identificadas na segunda parte do texto.

O processo de transformação institucional identificado e analisado neste trabalho é também um processo em curso. Seus pontos de chegada ainda não são claros e minha

\footnotetext{
${ }^{557}$ Cf. Gunter Teubner, Substantive and Reflexive Elements in Modern Law, p. 240

${ }^{558}$ Cf. Nonet e Selznick, Law \& Society in Transition, passim.

559 Cf. José Reinaldo Lima Lopes, Justiça e Poder Judiciário, passim.

${ }^{560}$ Cf. François Ost, Droit et Intérêt, passim.
} 
proposta não foi a de identificá-los, senão apenas a de apresentar e explicar, sob um ponto de vista ainda pouco usual na literatura jurídica brasileira, o próprio processo de modificação, que, imagina-se, pode ganhar, com essa análise, certa racionalidade global e alguma completude de sentido. Muitas questões, contudo, foram deixadas em aberto.

O problema da legitimidade da ação judicial, no novo contexto descrito, não foi abordado em profundidade, pois esse intento justificaria outra tese inteira. Igualmente não foi enfrentada em extensão a crítica institucional, cujo tratamento também demandaria outro trabalho. Os caminhos futuros do sistema judiciário brasileiro estão também em aberto. É possível identificar certa tendência ao aprofundamento dos instrumentos de mediação, inclusive no plano coletivo, e certa marcha em direção à concentração de poderes decisórios nos órgãos de cúpula, ao reforço do poder vinculante dos precedentes e à intensificação de mecanismos de uniformização de jurisprudência. Essas tendências acompanham outras tantas relativas a uma maior flexibilização procedimental e à acentuação do caráter plural dos mecanismos de representação de interesses. Todavia, se esses caminhos todos se explicam e podem ser interpretados como respostas aos movimentos identificados ao longo deste texto, é difícil imaginar se irão consolidar-se em efetivas modificações do sistema legal, ou se irão, em algum ponto, sofrer desvios de percurso.

A cultura judicial brasileira ainda é demasiadamente contraditória para permitir previsões mais claras que essas. Os dados empíricos o demonstram. Segundo informações da mais recente pesquisa encomendada pela Associação dos Magistrados do Brasil, por exemplo, 85,6\% dos magistrados entrevistados mostravam-se favoráveis à transformação do Supremo Tribunal Federal em uma corte constitucional, e 89,2\% consideraram justificável reduzir a possibilidade de recurso aos tribunais superiores ${ }^{561}$. No entanto, $61,2 \%$ dos juízes eram desfavoráveis à atribuição de efeito vinculante às súmulas dos tribunais superiores ${ }^{562}$ e quase $28 \%$ dos juízes na ativa afirmaram decidir de acordo com essas súmulas com "pouca" ou "nenhuma" freqüência. ${ }^{563}$ A incompatibilidade entre essas assertivas é evidente, pois apenas faz sentido haver uma corte constitucional e tribunais superiores especializados se a tarefa desses órgãos for racionalizar e uniformizar a jurisprudência com algum efeito prático importante. $O$ controle concentrado de

\footnotetext{
${ }^{561}$ Cf. V. Maria Tereza Sadek (coord.), Pesquisa AMB 2005, p. 46.

${ }^{562}$ Idem, ibidem.

${ }^{563}$ Idem, p. 64.
} 
constitucionalidade, por exemplo, função típica das cortes constitucionais, é incompatível com um regime em que o direito constitucional vigora sistematicamente de forma distinta em cada lugar, conforme o desejo e a interpretação do magistrado ali investido.

Essas incertezas quanto ao futuro são evidentes e não receberam, por isso, respostas prognósticas específicas ao longo deste trabalho. Mas há, para além delas, uma questão adicional, de grande importância, que também não foi, propositalmente, respondida. Essa questão diz respeito ao juízo valorativo que se poderia fazer quanto ao processo de judicialização em curso.

Em outras palavras, pergunta-se: haveria razão para acreditar em algum potencial de transformação social a partir da justiça, sobretudo em um contexto complexo como o brasileiro, que envolve subdesenvolvimento econômico, ausência de recursos materiais por parte da Justiça e uma miríade de ineficiências econômicas específicas ditadas pelo sistema jurídico, que insiste em apostar na retórica legislativa de princípios quase sempre irrealizáveis como instrumento primordial de redistribuição de renda? É sobre esse tema que pretendo fazer, tentativamente, alguns breves comentários conclusivos.

Paradoxalmente, a resposta a essa questão ainda tem sido dada, muitas vezes, em termos de uma compreensão abstrata e metafísica do princípio da separação de poderes. A própria crítica instrumental não deixa de, em alguma (ainda que reduzida) medida, dar conta de preocupações dessa ordem. Nessa análise, diz-se, como visto, que o potencial de transformação não existe porque o órgão judiciário não é materialmente competente, tomada a sua configuração institucional dada pelo arranjo da separação de poderes, para implementar modificações sociais. Faltam-lhe capacidade de planejamento, iniciativa própria e flexibilidade decisória, para dizer o mínimo. Quando a instituição reage forjando os instrumentos de trabalho necessários ao planejamento e à ação racional e valorativamente orientada, ela perde, diz a crítica, as próprias características que a legitimam, tornando-se autoritária. ${ }^{564}$ Nesse ponto, as críticas instrumental e de legitimidade se tocam.

As críticas de legitimidade esbarram ainda mais intensamente no problema da separação de poderes. Apontam que o judiciário não pode jamais gerir de maneira global e autônoma os rearranjos orçamentários necessários a implementar programas legislativos

${ }^{564}$ Cf., vg., José Ignácio Botelho de Mesquita, As Novas Tendências do Direito Processual..., passim. 
genéricos (pleno emprego, saúde para todos, educação universal), pois isso implicaria interferência indevida em esferas de poder alheias e alocacão de recursos por um órgão que não detém legitimidade representativa. Em uma versão mais simplificada da mesma crítica, diz-se, simplesmente, que a definição das próprias políticas é matéria constitucionalmente monopolizada pelos órgãos executivo e legislativo, que as formulam discricionariamente nas esferas de suas respectivas competências, independentemente dos programas, não vinculantes, contidos na norma. A justificação para tanto é dada, novamente, em termos de legitimidade representativa.

Também as respostas a esse último tipo de objeção são muitas vezes formuladas em termos de uma compreensão genérica dos postulados da separação de poderes e da legitimidade representativa. Segundo essa linha de argumento, diz-se, por exemplo, que a única forma de extrair conteúdo normativo substancial dos programas constitucionais genéricos é enxergá-los como norma jurídica de eficácia idêntica à de qualquer outra norma presente no sistema jurídico (ainda que de operação distinta, não excludente, conformada à estrutura dos princípios), o que faz do juiz, por vocação natural, intérprete autêntico e implementador prático por excelência desses programas. ${ }^{565} 566$ Assim, se foi o próprio direito (por intermédio de suas instituições representativas) que resolveu transformar anseios de pleno emprego e educação universal em norma jurídica (princípios de direito) e se, na dicção de Marshall, "é enfaticamente o domínio e dever do órgão jurisdicional dizer o que o direito significa", 567 nada haveria de mais natural senão dar, judicialmente, conteúdo material concreto a esses programas, sejam eles relacionados a direitos de conteúdo econômico e social, sejam relacionados a dilemas morais presentes na sociedade.

Os problemas envolvidos em ambas essas formas de raciocínio não são poucos, e minha intenção não é nem tratá-los aqui, nem resolver, nesta sede, os dilemas interpretativos que estão ligados à construção de uma ou outra noção de separação de poderes, de uma ou outra concepção de legitimidade democrática. Quero chamar a atenção,

\footnotetext{
${ }^{565}$ V. Ronald Dworkin, A Matter of Principle, especialmente os capítulos 1, 2 e 3, e Ronald Dworkin, Taking Rights Seriously, p. 81-100.

${ }^{566}$ Para uma crítica a essa tentativa de reduzir decisões políticas à implementação de certos princípios unidirecionados, que funcionariam de forma distinta das regras, v. Geoffrey C. Hazard Jr., Rising Above Principle,. V. tb. José Reinaldo Lima Lopes, Juízo Jurídico e a Falsa Solução dos Princípios e das Regras.

5675 US 135 (1803).
} 
apenas, para dois dados que me parecem importantes. Primeiro, do ponto prático, têm parecido substancialmente infrutíferas as incursões mais incisivas do judiciário brasileiro na redefinição autônoma e auto-suficiente de políticas públicas. Segundo, parece haver, em ambos os discursos referidos acima, uma certa distorção comum, consistente na simplificação exagerada das complexidades inerentes a uma sociedade que é marcada, sobretudo, pelo pluralismo, que é caracterizada pelo dissenso.

No que diz respeito ao primeiro aspecto, a experiência parece mostrar que, quando o Judiciário é defrontado, no plano coletivo, com toda a miríade de problemas práticos que está envolvida na redefinição material de políticas públicas, ele simplesmente abandona essa tarefa. Isso é empiricamente demonstrado de várias formas. Fica claro quando olhamos para decisões que implementam direitos sociais no plano individual mas admitem que seus comandos não podem ser universalizados. ${ }^{568}$ Fica claro quando percebemos que a redefinição de políticas sociais respondeu por apenas 1,6\% de todo o conjunto de ações coletivas tramitadas em determinado período na Comarca do Rio de Janeiro. ${ }^{569}$ Desponta quando consideramos que o índice de sucesso dessas mesmas ações na mesma Comarca, em um outro determinado período, foi igual a zero, em virtude de motivos processuais. ${ }^{570}$

O segundo aspecto, relativo à completa desconsideração do pluralismo e complexidade sociais, chama a atenção, de fato, tanto nos discursos favoráveis à intervenção do judiciário quanto nos desfavoráveis. Os primeiros justificam a ação do juiz com base em uma ficção, consistente na existência de princípios jurídicos capazes de ditar, a cada determinada decisão, qual o único caminho correto a seguir, qual o destino a ser dado aos bens coletivos. Os demais lançam mão de uma mesma ficção ao justificar o

${ }^{568}$ V. nota 305 , acima.

569 Cf. Luiz Werneck Vianna (org.), A Democracia e os Três Poderes no Brasil, p. 478.

${ }^{570}$ Paulo Cezar Pinheiro Carneiro, Acesso À Justiça: Juizados Especiais e Ação Civil Pública - uma Nova Sistematização da Teoria Geral do Processo, p. 200. Segundo esse autor, "enquanto as ações relativas ao direito do consumidor, em primeiro lugar (51,85\%) entre as julgadas... tiveram resultados, no conjunto, razoáveis, aquelas que se referem à cidadania (duas), ao patrimônio cultural (uma) e sobre improbidade administrativa (uma) apresentaram um único desfecho: extinção sem o julgamento do mérito. As causas para o fenômeno... podem ser as mais variadas possíveis, dependendo do ângulo em que se examine a situação. Ela pode decorrer da melhor estrutura e experiência, inclusive no tempo, do Ministério Público estadual, especificamente na proteção do meio ambiente e do consumidor... Pode derivar do fato de tais direitos serem, na prática, mais sujeitos a violação... Sob a ótica política, o fato de que esses tipos de direitos, em especial aqueles relativos à cidadania em geral, notadamente os direitos sociais, envolvem diretamente os altos governantes do País, não encontrando especialmente no setor público quem possa protegê-los adequadamente... Finalmente, visualizamos, do ponto de vista prático, grande dificuldade em fazer valer esses tipos de direito, especialmente os relativos à cidadania, ainda que vitoriosa a ação, pois não existem meios legais fortes para compelir os governantes a cumprir tais decisões, sendo praticamente impossível a execução específica" (idem, ibidem.) 
afastamento do judiciário: consideram que o processo representativo outorga, ao governante, legitimidade suficiente para funcionar, a cada determinada decisão, como "oráculo" do interesse público, assim coeso e unidirecionado, determinando o destino desses mesmos bens. Direta ou indiretamente, ambas as noções lançam mão da idéia de interesse público (o intérêt général do direito francês) como ferramenta conceitual, sendo que a primeira pensa conseguir identificá-lo nos termos da própria lei, e a segunda outorga à administração a capacidade de interpretá-lo e de dizer qual é sua configuração particular a cada caso. O problema, nesse passo, é que a própria noção de interesse público, se é que unívoca já foi em alguma parte, parece estar, presentemente, em crise.

Essa crise tem origens variadas e está diretamente implicada no processo de reapropriação, pela sociedade civil, da condução de seus próprios interesses, em um contexto de pluralismo de opiniões e perspectivas. O Estado perde, nesse contexto, a capacidade de imposição externa de sua concepção de bem comum e a própria noção de um interesse social unívoco passa a soar, como apontou Luigi Graziano, como "metafísica". ${ }^{571}$ Numa sociedade tornada complexa, a tutela do interesse público mais e mais parece ser substituída por mecanismos públicos e institucionalizados de barganha. ${ }^{572}$

Segundo parte da literatura, esse contexto plural mina a própria capacidade de prescrição substancial do direito, atribuindo às várias esferas sociais espaço amplo para a auto-regulação. ${ }^{573}$ Nesse contexto, que papel poderia sobrar ao órgão judicial, se nem mais ao Estado é garantida a primazia de definição das políticas públicas? Uma nova imersão na realidade brasileira pode ajudar a responder essa questão.

Segundo os dados disponíveis até o momento, parece haver certo consenso quanto à primazia, no plano da tutela de interesses difusos no Brasil, de questões ligadas ao consumo e à proteção do meio ambiente. Essa primazia pode ser observada pela análise

\footnotetext{
${ }^{571}$ V. Luigi Graziano. O Lobby e o Interesse Público.

572 "O elemento-chave nessa reformulação, de acordo com a qual não há um interesse público único, mas muitos interesses públicos (no plural), é a natureza da filiação ao grupo e os critérios de sua seleção. Exemplificando, se qualquer pessoa que deseje lutar por uma causa pública pode inscrever-se numa associação defensora da abolição da pena de morte, ou na Handgun Control, Inc., um lobby que combate a compra e venda de armas de porte, apenas os arquitetos podem filiar-se a uma associação de arquitetos. $\mathrm{O}$ mesmo se aplica à Business Roundtable, que só aceita membros pertencentes às grandes empresas americanas, ou a qualquer órgão associativo de natureza profissional ou econômica. Conforme observou Schattschneider (1960), os interesses especiais são especiais no mesmo sentido em que a propriedade privada é especial e exclusiva, ao passo que os lobbies públicos articulam os interesses mais amplos que podem surgir numa sociedade" (Idem, ibidem).

${ }^{573}$ V. Gunter Teubner, Substantive and Reflexive Elements..., p. 251.
} 
dos dados contidos nas tabelas 07 e 08, abaixo, e poderia explicar-se de vários modos: (i) maior facilidade de organização dos interesses relacionados a esses temas, (ii) afetação direta das camadas intermediárias da população, com as quais tanto o Ministério Público quando o conjunto dos magistrados parecem identificar-se, ${ }^{574}$ (iii) maior facilidade na implementação das decisões, (iv) o impacto distributivo das decisões pode ser, efetivamente, mais baixo, (vi) a implementação das decisões envolve em menor grau o gerenciamento e realocação de recursos pertencentes ao orçamento público, (vii) há menor dissenso quanto ao teor dos interesses difusos envolvidos (problema de "interpretação" do interesse público), etc.

Se esses fatores forem realmente determinantes, e se for correto afirmar que eles estão mais presentes na tutela do consumo que na proteção do meio ambiente, essas hipóteses ficam confirmadas pelos dados disponíveis. Na pesquisa realizada entre os anos de 1985 e 1996, 53,12\% dos casos julgados em matéria de consumo receberam sentenças de procedência total ou parcial, contra $15,2 \%$ dos casos julgados em matéria ambiental. Os dados relativos aos outros tipos de interesse revelaram, como já referido, índices de sucesso ainda mais reduzidos. ${ }^{575}$

Parece ser inegável a contribuição dada por esse sistema de judicialização à tutela dos interesses de consumo, em que pesem exageros e desvios ocasionais. Também parece ter sido importante o desenvolvimento de um mecanismo efetivo de proteção judicial na área da proteção ambiental. Mas o que dizer, contudo, das demais espécies de interesses difusos, sobretudo quando ligadas a políticas públicas envolvendo cidadania e alívio da pobreza, alocação de vagas em instituições públicas, acesso a serviços e bens essenciais, etc.? É correto imaginar que a ausência de sentenças de procedência corresponde à completa inefetividade da ação judiciária nesses temas? A experiência concreta parece negar essa assertiva.

\footnotetext{
${ }^{574}$ V., quanto ao perfil sócio-econômico-cultural dos integrantes do Ministério Público, o texto que acompanha a nota 161 , acima. Para um perfil semelhante da magistratura brasileira, v. Luiz Werneck Viana et al. Corpo e Alma da Magistratura Brasileira. V. tb. Maria Tereza Sadek (coord.), Pesquisa AMB 2005, passim. Parece haver uma clara tendência de recrutamento dos magistrados entre as camadas intermediárias da população. Segundo esta última pesquisa, a maior parte deles não possui parentes ligados à área jurídica e é oriunda de famílias cujos pais não chegaram a freqüentar curso superior. Aproximadamente $40 \%$ dos magistrados são filhos de pais que estudaram até o primeiro grau. $83,8 \%$ admitem considerar as conseqüências sociais de suas sentenças ao decidir.

575 Cf. Paulo César Pinheiro Carneiro, ob. cit., passim.
} 
Proteção do consumidor

Proteção do meio ambiente

Proteção do menor

Proteção do patrimônio cultural

Cidadania

Probidade administrativa

Outros
$36,78 \%$

$44,82 \%$

$9,19 \%$

$2,30 \%$

$2,30 \%$

$1,14 \%$

$3,44 \%$

(Fonte: Paulo Cezar Pinheiro Carneiro, Acesso à Justiça, Rio de Janeiro: Forense, 1999).

\section{(Tabela 08) \\ TIPO DE INTERESSE DEMANDADO \\ (Por classificação material) \\ (1996-2001)}

Proteção do meio ambiente

Proteção do consumidor

Proteção do menor

Questões de política pública

Questões envolvendo a Administração e probidade

Proteção do idoso

Outros
$35,4 \%$

$34,9 \%$

$12,9 \%$

$7,5 \%$

$5,9 \%$

$1,0 \%$

$1,0 \%$

(Fonte: Luiz Werneck Vianna e Marcelo Burgos, Revolução processual do direito e democracia progressiva, in Luiz Werneck Vianna (org.), A democracia e os três poderes no Brasil, Rio de Janeiro: IUPERJ/FAPERJ, 2002, p. 465.

Não é incomum que o simples fato de ser ajuizada uma ação judicial questionando uma dada política pública provoque, independentemente do resultado final da ação, efeitos importantes nas dinâmicas relacionadas a essa mesma política. Ou seja: ação judicial atrai atenção para as decisões coletivas, obriga os órgãos públicos a explicarem suas razões em termos de princípios aceitáveis de persecução do bem comum, projetam para a arena pública interesses que, de outra forma, teriam imensa dificuldade em articular-se no plano da representação política formal. Além de amplificar a voz desses interesses a um custo relativamente baixo (significativamente mais baixo que a atuação política via lobby legislativo ou governamental, por exemplo), a judicialização dos temas políticos obriga o poder público a dialogar com interesses que poderiam estar, em princípio, excluídos, pois a submissão de razões ao órgão judiciário é obrigatória e não facultativa. Questões de política pública que se projetam para a arena judicial conhecem, ademais, uma exposição 
na mídia presumivelmente superior em relação àquelas que não se judicializam, amplificando-se, dessa sorte, o aspecto de prestação de contas apontado como fundamental às concepções deliberativas de democracia. ${ }^{576}$

Segundo José Reinaldo Lima Lopes, a atuação judiciária em sede de políticas públicas chamaria a atenção, portanto, para dois fenômenos importantes: "o fato de o judiciário converter-se numa arena de discussão em que as partes podem racionalizar seus interesses e sua concepção ético-jurídica, e o fato de que os bloqueios institucionais eventualmente criados por demandas judiciais têm a capacidade de explicitar conflitos sociais básicos da sociedade brasileira. $\mathrm{O}$ valor do Judiciário é garantir que os arranjos e disputas se façam sob a legalidade e dar visibilidade às diferentes reivindicações. Num sentido limitado, permite que o diálogo se estabeleça formalmente entre litigantes."

Não é fato desconhecido que a deliberação pública conhece, por si só, debilidades importantes no que diz respeito à sua capacidade de dar tratamento igual a todos os interesses nela envolvidos. Não fossem outros empecilhos institucionais, isso ocorre pelo só fato de haver maior dificuldade na mobilização de interesses espalhados por grandes grupos, para os quais a alocação individual de vantagens não justifique a sua persecução. ${ }^{577}$ Essas debilidades se tornam tanto mais importantes quanto maiores forem os custos (i) de participação formal no processo político representativo e (ii) de participação substancial nesse mesmo processo, entendida esta como uma participação qualificada capaz de influenciar, efetivamente, o resultado final desse processo. Em um contexto de corrupção e clientelismo, os custos relativos a essa participação qualificada sobem sobremaneira, tornando ainda mais desiguais as condições de competição entre os vários interesses que se contrapõem na definição de uma dada política pública. Do ponto de vista prático, a justiça brasileira parece estar prestando um serviço valioso à democracia exatamente ao reduzir os custos desse tipo de participação qualificada, o que parece ter sido sentido em matérias tão díspares quanto a definição de políticas de privatização, o reajuste de tarifas públicas, a construção de estradas sobre áreas de preservação ambiental, a destinação de parques e áreas públicas, a distribuição de remédios e vagas em instituições públicas e muitas outras.

\footnotetext{
${ }^{576}$ V. a propósito Amy Gutmann, A Desarmonia na Democracia.

577 V. Mancur Olson. The Logic of Collective Action, passim. V. tb. Robert A. Dahl. Pluralism Revisited. Comparative Politics.
} 
A percepção teórica dessa função de reorganização das forças políticas, de desestabilização institucional e de amplificação de interesses sub-representados não é inédita. De certa forma, ela remete a reflexões teóricas que têm se tornado comuns no plano da teoria jurídica, apontando para uma tendência de procedimentalização do direito. $\mathrm{Na}$ forma como a estou apresentando, relacionada especificamente à ação do Judiciário no contencioso de direito público, talvez sua primeira formulação significativa tenha sido feita por Colin Diver, em artigo escrito em 1979. ${ }^{578}$ Diver define a função judicial assim concebida como uma função de "intermediação de poder político". Define o juiz, portanto, como um political powerbroker.

Segundo Diver, o contencioso envolvendo políticas públicas, "mais que um evento isolado e auto-contido... torna-se um componente em um processo contínuo de barganha política que determina a forma e o conteúdo da política pública. Essa transformação no caráter do litígio necessariamente transforma o papel do juiz. O juiz passa a confiar, do ponto de vista de sua influência, muito mais na troca que na coação e, por conta desse modo de operar, muito mais na barganha que na adjudicação. Ele usa sua posição central no processo para exercer influência além das fronteiras imediatas do caso colocado diante dele, aferindo e pesando o impacto de resultados atingidos em seu gabinete sobre a distribuição de influência no mundo exterior. O juiz assume o papel, em essência, de um gerenciador de poder político". 579

No modelo de Colin Diver a ação judicial deixa de ser um evento externo ao processo político para tornar-se parte desse mesmo processo. ${ }^{580} \mathrm{~A}$ decisão torna-se secundária: é o processo de decisão que fornece os mecanismos de impacto político. ${ }^{581}$ Mais que qualquer outra coisa, é a "visibilidade" do processo judicial que cria oportunidades para a realização de movimentos estratégicos no cenário político. ${ }^{582}$ Nesse quadro, os custos implicados nas estratégias "evasivas" da administração (ignorar os

\footnotetext{
${ }^{578}$ Colin S. Diver. The Judge as a Political Powerbroker: Superintending Structural Change in Public Institutions.

579 Idem, p. 43.

580 Idem, p. 65.

581 Idem, ibidem.

${ }^{582}$ Idem, ibidem.
} 
interesses de certos grupos minoritários, por exemplo) são consideravelmente aumentados. $^{583}$

Se é certo que essa posição do juiz como um gerenciador de poder político não se apresenta isenta de riscos, sobretudo ligados a desvios de parcialidade e manipulação 584 (no mais, sempre apontados como riscos inerentes a um papel judicial mais ativo), ${ }^{585}$ para Colin Diver as estratégias mais eficientes de intervenção judicial serão aquelas que confiarem, em maior medida, nos processos de barganha política já existentes, pois serão as estratégias capazes de permitir maior oportunidade de participação ativa daqueles afetados na política em discussão. ${ }^{586} \mathrm{O}$ potencial desse tipo de contencioso consiste, portanto em lançar ao debate público interesses que de outra forma não atingiriam os processos formais de barganha política, além de "chacoalhar o governo", colocando-o em ação. Seu objetivo não é o de resolver o conflito político mas o de rearranjar as forças políticas de modo a permitir uma solução externa em bases mais democráticas e eqüitativas. $\mathrm{O}$ foco é, portanto, mais nos processos de participação que na decisão final. $\mathrm{O}$ valor desse tipo de função judicial repousa mais no processo de intervenção que na substância de seu resultado. ${ }^{587}$

Charles Sabel e William Simon apresentaram recentemente uma formulação muito parecida acerca do contencioso de interesse público nos Estados Unidos, lançando mão da idéia de "direitos de desestabilização", forjada por Roberto Mangabeira Unger (direitos à desestruturação de instituições que sistematicamente falham no atendimento de seus objetivos e que acabaram por imunizar-se aos processos normais de responsabilização política). ${ }^{588}$ Para esses autores a evolução desse tipo de contencioso teria mudado de um modelo de regulação baseado em mecanismos de comando e controle para um modelo experimental de intervenção, caracterizado pela flexibilidade, pelo caráter provisório de suas normas e por procedimentos capazes de gerar participação constante dos interessados, bem como responsabilização (accountability) dos agentes públicos envolvidos. ${ }^{589}$

\footnotetext{
583 Idem, p. 66.

584 Idem, p. 89.

585 V. José Roberto dos Santos Bedaque, Poderes Instrutórios do Juiz, p. 105 e ss.

${ }^{586}$ Colin S. Diver, ob. cit., p. 90.

587 Idem, p. 92.

${ }^{588}$ V. Charles F Sabel.; William H. Simon. Destabilization Rights: How Public Law Litigation Succeeds. ${ }^{589}$ Idem, p. 1019.
} 
É curioso que os autores usem a expressão "direitos de desestabilização", pois ela parece remeter justamente àquela função criadora do interesse a que se referia François Ost: "[s]e o interesse suscita intervenções de compromisso, poder-se-ia dizer que ele opera como fator permanente de desestabilização de situações estabelecidas e de direitos adquiridos. Elemento de defesa do status dos jogadores mais fracos, o interesse surge evidentemente como fator de insegurança se nos colocarmos sob o ponto de vista dos jogadores mais privilegiados. $\mathrm{Na}$ verdade, é a própria regra que parece agora afetada por um coeficiente de variabilidade em razão de levar em conta uma gama maior ou menor de interesses." 590

Para Sabel e Simon, "o efeito da intervenção inicial das cortes”, nesse contexto, é o de "desestabilizar as expectativas das partes anteriores ao litígio, de modo a provocar efeitos políticos, cognitivos e psicológicos que aumentem sua disposição à colaboração experimental." ${ }^{591}$ No modelo imaginado por esses autores, de forma distinta em relação àquele sugerido por Colin Diver, o resultado substancial da intervenção judicial importa também. Contudo, esse resultado liga-se aos atores envolvidos no processo por meio de uma relação de coordenação e não de subordinação. Ao invés de ditarem comportamentos e desenharem políticas específicas, as decisões fornecem os standards segundo os quais as políticas deverão, autônoma e negociadamente, ser produzidas. ${ }^{592}$ "Em alguma medida... esse movimento reflete um sentido de inadequação das aproximações de comando e controle. As cortes perceberam que não têm nem a informação nem a profundidade e amplitude de controle para formular propriamente e implementar instrumentos de tutela baseados em comando e controle". 593 Sua função passa a ser, portanto, a de "facilitar o processo de deliberação e negociação entre os interessados". 594

Assim como no modelo de Colin Diver, uma das virtudes do processo de implementação desses "direitos de desestabilização" é forçar as esferas do poder público a responderem aos interesses de grupos previamente excluídos do debate público. ${ }^{595}$ São direitos oponíveis, portanto, contra o insulamento das burocracias estatais e parlamentares

\footnotetext{
${ }^{590}$ François Ost, Droit et Intérêt, p. 77.

${ }^{591}$ Charles Sabel e William Simon, ob. cit., p. 1020.

${ }^{592}$ Idem, p. 1026: "Instead of directing specific action, the decrees elaborate goals and methods of monitoring achievement.".

${ }^{593}$ Idem, p. 1053.

${ }^{594}$ Idem, p. 1055.

${ }^{595}$ Idem, p. 1056.
} 
e dos grupos de poder. ${ }^{596}$ Direitos, portanto, ao estabelecimento de formas mais democráticas de barganha política, que se perdem quando (i) as instituições políticas majoritárias tornam-se "irresponsivas" aos interesses de uma minoria vulnerável e marginalizada, ou (ii) a própria lógica da ação coletiva aponta para a sub-representação do interesse (grupos cujos membros têm interesses bem delimitados e concentrados sobrepõem-se sobre grupos muitos maiores, cujos interesses são de tal forma difusos que tornam a organização política improvável) ou (iii) a ação coletiva, para tornar-se racional, precisa de coordenação (o conhecido dilema do prisioneiro da teoria dos jogos), mas as instituições responsáveis falham em provê-la. Além disso, assim como no modelo de Colin Diver, o contencioso assume a forma de um jogo, no qual a jurisdição atua, por vezes, através de ameaças cuja efetivação poderia, em tese, causar à própria corte danos de legitimidade superiores aos benefícios correspondentes (ameaças de imposição de sanções graves mas de difícil execução, com vistas a estimular mecanismos espontâneos de reorganização dos interesses em questão ${ }^{597}$ ).

Os modelos acima referidos convergem, portanto, em muitos pontos, sobretudo no que diz respeito às funções de inserção no debate público de interesses sub-representados e de reestruturação das dinâmicas de força previamente existentes entre os interessados. ${ }^{598}$ Curiosamente, Sabel e Simon destacam, ainda, uma característica interessante de seu modelo, consistente em uma espécie de "externalidade positiva" do policentrismo: à medida em que os tribunais atuam no sentido de "desestabilizar" instituições não responsivas, os efeitos da desestabilização ultrapassam as instituições que atingem e alcançam outras instituições, ultrapassando também as razões específicas que justificaram a intervenção e alcançando um mecanismo auto-reforçado de reavaliação e correção. ${ }^{599}$

O viés procedimental dessas abordagens é evidente. Nesse contexto, comunica-se de certo modo com algumas importantes tentativas de reconstrução dos parâmetros de interpretação constitucional empreendidas na segunda metade do século passado, sendo uma das mais conhecidas a de John H. Ely, voltada ao "reforço das condições de

\footnotetext{
${ }^{596}$ Idem, ibidem. V. tb. Roberto Mangabeira Unger, False Necessity: Anti-Necessitarian Social Theory in the Service of Radical Democracy From Politics : A Work in Constructive Social Theory.

597 Charles Sabel e William Simon, ob. cit., p. 1067.

598 Idem, p. 1077

599 Idem, p. 1080.
} 
participação". ${ }^{600}$ Recentemente, essa abordagem de Ely foi retomada por William N. Eskridge Jr., que propôs um modelo segundo o qual poderiam os tribunais "ajudar a democracia, baixando os custos de ingresso no jogo político". ${ }^{601}$

Eskridge não está preocupado com intervenções judiciais em instituições públicas ou em políticas administrativas, mas, sobretudo, com a interpretação constitucional em matérias de intensa divergência moral (direitos de integração racial, uniões homo-afetivas, aborto, condição feminina, etc.). Não obstante, seu modelo de interpretação constitucional espelha o caráter procedimental das intervenções judiciais referidas acima. Quando elas se direcionam a revisar o status de subordinação de certos grupos marginalizados, permitem a inserção desses grupos no debate público, reduzindo-lhes, por isso, os custos de ingresso no jogo político. Quando avançam esse limite e decidem por si sós questões morais ainda polêmicas no corpo social, arrancam essas questões do debate público, aumentando, assim, para todos, os custos de ingresso no jogo político respectivo.

Referindo Guinier, Eskridge afirma que "a regra da maioria... sofre quando não é constrangida pela necessidade de negociar com interesses minoritários". ${ }^{602}$

Para Eskridge, as cortes podem promover os ideais democráticos de uma sociedade multicultural e pluralista basicamente por três meios: (i) aplicando regras neutras que permitam a participação política a todos os grupos interessados, (ii) amenizando as "guerras culturais" encontráveis no corpo social, e (iii) invertendo os ônus da inércia legislativa que dificulta a modificação de leis obsoletas e que marginalizam grupos sociais, minando-lhes o poder de participação no debate político. ${ }^{603}$

A noção do processo judicial como elemento interno ao jogo político, referida por Colin Diver, é identificada, no Brasil, por Luiz Werneck Vianna et al. ${ }^{604}$ Mas esses autores vão além das análises referidas acima e coloca relevo em um elemento tão importante quanto a participação: a racionalização do debate coletivo, provocada por sua judicialização. Nesse contexto, produz-se uma espécie de "conversão virtuosa", para

\footnotetext{
${ }^{600}$ Cf. John H. Ely. Democracy and Distrust : A Theory of Judicial Review.

${ }^{601}$ Cf. William N. Eskridge Jr. Pluralism and Distrust: How Courts Can Support Democracy by Lowering the Stakes of Politics.

${ }^{602}$ Idem, p. 1295.

${ }^{603}$ Idem, p. 1310.

${ }^{604}$ Cf. Luiz Werneck Vianna et al. Corpo e Alma da Magistratura Brasileira, p. 45.
} 
recuperar o conceito de Füller: a transformação dos debates em "disputas sobre direitos" obriga as partes a enunciarem seus interesses, como já mencionei acima, de acordo com alguma noção minimamente defensável de bem comum. Para Vianna et al:

\begin{abstract}
"a democracia deliberativa, com sua estratégia de uso alternativo do direito, escora sua intenção de atingir a uma 'bem ordenada democracia igualitária' por meio de uma radicalização republicana, em que os cidadãos se relacionam 'não apenas afirmando a própria vontade ou lutando por seus interesses predeterminados, mas também influenciando uns aos outros por meio do uso publicamente valorizado de argumentos, evidências e julgamentos fundamentados, e da persuasão que recruta argumentos para sua causa'. Sittlichkeit de sociedade civil, contínuo plebiscito em torno de valores, a cidadania inventaria a si mesma em um contexto pluralista, compondo, por isso mesmo, uma noção de bem comum sujeita a diferentes interpretações, e a que se chegaria por procedimentos da democracia deliberativa. Emancipado da sua rigidez e da estabilidade dos sistemas, o Direito - o patrimônio jurídico de valores e de procedimentos - se tornaria o novo lugar da inovação social, embora, no mundo de Hermes, o ator protagonista não necessariamente seja parte do Poder Judiciário., ${ }^{, 65}$
\end{abstract}

Desenha-se, assim, para esses autores, o âmbito de ação de uma "democracia complexa" e "progressiva", que se apóia, também, na "revolução processual do direito" para racionalizar e democratizar os termos do debate público. ${ }^{606}$

Esse elemento de racionalização parece-me fundamental, ditando parte importante da contribuição que o direito (e a judicialização dos conflitos públicos) pode dar à prática política democrática. É um elemento que supera o papel puramente processual, "reflexivo" da institucionalização de meios eqüitativos de participação. ${ }^{607}$ Sua melhor apreensão é feita por Nonet e Selznick em sua noção de "direito responsivo", ${ }^{608}$

No modelo de Nonet e Selznick, o ponto fundamental de inflexão do sistema jurídico é localizado na tendência de generalização dos objetivos do ordenamento

${ }^{605}$ Idem, p. 42.

${ }^{606}$ V. Luiz Werneck Viana; Marcelo Burgos. Revolução Processual do Direito e Democracia Progressiva.

${ }^{607}$ Reversamente, sobre a centralidade do papel reflexivo, v. Gunther Teubner, ob. cit., passim. V. tb. Celso F. Campilongo. Direito e Democracia.

${ }^{608}$ V. Philippe Nonet; Philip Selznick. Law \& Society in Transition: Toward Responsive Law. A "mistura" de elementos reflexivos (procedimentais) e substanciais na noção de direito responsivo, forjada pelos autores, é objeto das críticas de Teubner formuladas no texto citado acima. Parece-me, contudo, que essa amálgama de uma base procedimental instalada sobre bases substanciais seja a virtude do modelo. $\mathrm{O}$ direito responsivo passa a estabelecer as condições de mediação dos conflitos, ditando não apenas os mecanismos de participação mas também indicando quais são os argumentos válidos e os inválidos, e quais são os resultados finais possíveis e os impossíveis. Essa parece ser uma fotografia bastante mais fiel do fenômeno jurídico tal como é hoje encontrável, ainda que talvez não seja, sob uma perspectiva evolucionista (a perspectiva de Teubner) a melhor aposta quanto aos desenvolvimentos futuros do sistema jurídico. 
nacional. As regras, as políticas e os procedimentos passam a ser vistos sob uma perspectiva instrumental em relação a objetivos mais genéricos de convivência humana. Há sempre, sob as normas, valores implícitos a buscar. ${ }^{609}$ Como fruto da rematerialização do direito liberal (direito autônomo) instaura-se uma "soberania do propósito" "610 que, junto com a necessidade de construção de uma ordenação jurídica capaz de "lidar com a mudança,"611 termina por minar a capacidade direta de controle de comportamentos por parte do direito. O julgamento jurídico perde sua "força oracular" e passa a incorporar elementos da análise política, sendo forçado a administrar interesses conflitantes. ${ }^{612} \mathrm{O}$ tema do pluralismo é recorrente:

\begin{abstract}
"Um dos efeitos do pluralismo jurídico é multiplicar oportunidades dentro do processo legal para participação na construção do direito. Dessa forma a arena legal transforma-se em um tipo especial de fórum político e a participação jurídica toma uma dimensão política. Em outras palavras, a ação jurídica acaba servindo como um veículo pelo qual grupos e organizações podem participar na determinação de uma dada política pública. É menos percebida exclusivamente como um modo de apresentar demandas individuais baseadas em regras reconhecidas.",613
\end{abstract}

Como nos modelos anteriores, a diferença fundamental do modelo responsivo é que a ordem não é dada por subordinação, mas é negociada. Por isso, sobretudo no plano público, "afirmações de direitos são compreendidas como oportunidades para corrigir desordens e disfunções e, portanto, podem ser consideradas como recursos administrativos positivos. Mas a solução dos conflitos não pode permanecer sendo a preocupação paradigmática... A energia do direito deve ser devotada ao diagnóstico de problemas institucionais e ao redesenho de arranjos institucionais. Novos modos de supervisão, novas formas de aumentar a visibilidade das decisões, novas unidades organizacionais, novas estruturas de autoridade, novos incentivos - esses são os remédios característicos de um direito comprometido com propósitos." ${ }^{, 614}$ O objetivo é a justiça substancial, mas ela não se atinge por interpretação das normas jurídicas e sim pela construção de instituições responsivas. ${ }^{615}$

\footnotetext{
${ }^{609}$ Idem, p. 78.

${ }^{610}$ Idem, ibidem.

611 Idem, p. 81.

612 Idem, p. 85.

613 Idem, p. 96.

${ }^{614}$ Idem, p. 106-7.

${ }^{615}$ Idem, p. 108-9.
} 
Talvez a capacidade material das cortes de justiça ainda não permita, no Brasil, tarefas de reconstrução institucional tão sofisticadas. Mas a ação dessas cortes já vem apresentando uma característica responsiva importante, uma função de gerenciamento e reequilíbrio de poder político, de amplificação do impacto político de certos interesses subrepresentados e, finalmente, de racionalização da barganha política por meio de sua intermediação por raciocínios fundados em alguma noção de bem comum. Essa não tem sido uma tarefa organizada, nem consciente, intencional ou racionalizada, mas parece vir desempenhando um papel verdadeiramente importante na reconstrução do ambiente democrático nacional. Parece, portanto, ser uma função merecedora de avaliação positiva.

No contexto das idéias discutidas acima, talvez tanto a crítica instrumental quanto a crítica de legitimidade acabem perdendo boa parte de sua razão, uma vez que a solução material dos litígios sobre bens coletivos passa cada vez menos a ser o objetivo final desse contencioso de interesse público. Aliás, nem o parlamento ou o executivo conseguem mais ser foco único de solução desses conflitos. Os conflitos são multifacetados e sua solução é múltipla e plural, remetendo, enfim, a uma acomodação institucional complexa na qual o papel das cortes de justiça parece ser o de referir a discussão a critérios racionais mais que a preferências egoístas, o de reequilibrar dinâmicas de força e garantir a voz dos interesses sub-representados, o de desestabilizar instituições que deixam de se mostrar "responsivas" aos papéis para os quais foram criadas..

Talvez a função das cortes brasileiras nesses conflitos seja mesmo, portanto, a de participar desse emaranhado jogo político, efetivando "direitos de desestabilização", "baixando os custos de ingresso no jogo político", "gerenciando os poderes políticos" pertinentes a cada agente e colaborando, assim, para a construção de uma "democracia complexa" em um contexto de "direito responsivo" no qual a "justiça social" se atinge por meio de "instituições", não de ordens de subordinação.

Em outras palavras, se a ação política do Judiciário parece ser conseqüência necessária do Estado Regulador, ${ }^{616}$ ela deveria, em princípio, manter-se fiel à sua

${ }^{616}$ V. Abram Chayes. The Role of the Judge in Public Law Litigation, p. 1302: "I would, I think, go further and argue that just as the traditional concept reflected and related to a system in which social and economic arrangements were remitted to autonomous private action, so the new model reflects and relates to a regulatory system where these arrangements are the product of positive enactment. In such a system, enforcement and application of law is necessarily implementation of regulatory policy. Litigation inevitably becomes an explicitly political forum and the court a visible arm of the political process". 
racionalidade de coordenação, não de direção e subordinação. ${ }^{617}$ No entanto, há um grande risco de subversão da racionalidade própria a esse arranjo institucional. Na experiência brasileira, esse risco é potencializado, pois parece haver um importante e pernicioso consenso entre os atores envolvidos no jogo judiciário acerca do caráter hiposuficiente da população, a demandar tutela por parte das autoridades constituídas. ${ }^{618}$

Além disso, é preciso compreender as deficiências inerentes a esse arranjo.

A primeira delas consiste em decorrência da constatação já feita anteriormente no sentido de ser, a tutela judicial de interesses ligados ao domínio público, ela mesma uma forma de ação coletiva. ${ }^{619}$ Por isso, sofrerá dos mesmos e exatos problemas que se apresentam, de acordo com a teoria dos grupos, na ação coletiva. Sofrerá ela mesma, sobretudo, dos mesmos problemas de sub-representação que visa combater.

No Brasil, parte desses problemas é resolvida pela instituição do Ministério Público. Contudo, como visto acima, essa parece ser uma instituição que responde aos interesses das camadas médias da população, reduzindo seus custos de organização. Essas camadas certamente não seriam capazes de atingir o processo político formal, e talvez fossem, em alguns casos, capazes de organizar esforços para levar seus interesses ao plano político por meio da justiça. Mas isso não ocorreria na maioria dos casos. Nesse ambiente, o Ministério Público parece se apresentar a essas camadas como uma via mais barata de ação política. Organizadas suficientemente a ponto de pressionar eficazmente a ação do órgão, elas conseguem colocá-lo em ação na defesa de seus interesses. Não por acaso as estatísticas apontam, como visto, a prevalência dos interesses de consumo, próprios por excelência às camadas médias, entre o universo das ações coletivas ajuizadas perante a justiça brasileira. Em segundo lugar ficam os interesses ligados à proteção do meio ambiente, também referidos, ainda que menos intensamente, aos interesses dessas mesmas camadas intermediárias.

617 "If there is a paradigmatic function of responsive law it is regulation, not adjudication. Broadly understood, regulation is the process of elaborating and correcting the policies required for the realization of a legal purpose. Regulation thus conceived is a mechanism for clarifying the public interest. It involves testing alternative strategies for the implementation of mandates and reconstructing those mandates in the light of what is learned." Nonet e Selznick, ob. cit., p. 108-9.

618 V. nota 161 , acima.

${ }^{619}$ Cf. Stephen C. Yeazell. Collective Litigation as Collective Action. University of Illinois Law Review, v. 1989, p. 43-68.. 
O que ocorre, contudo, com os grupos que não conseguem ainda angariar qualquer capacidade de organização política, nem para movimentar a máquina judiciária, nem para pressionar o Ministério Público? Esses grupos tenderão a continuar sub-representados, tanto mais quanto menos visíveis socialmente forem suas demandas. Daí haver, entre os interesses sub-representados, uma escala descendente que parece começar com a proteção dos menores e adolescentes (que veiculam interesses com baixa capacidade de organização mas de alta visibilidade política), passam pelos interesses da população carcerária (baixa organização e média visibilidade política) e terminam com os interesses dos indigentes e miseráveis nas cidades e no campo, que são simplesmente ignorados por sua completa incapacidade de organização, aliada à total invisibilidade de seus interesses, no espaço nacional.

Isso significa, portanto, que o potencial democrático apresentado pelas cortes de justiça, que existe e parece ficar claro a partir das considerações feitas acima, está muito longe de representar panacéia para os problemas sociais da nação. Estes se resolvem por meio de ação estatal organizada, de redistribuição racional de renda, pela criação de instituições estáveis e por meio de crescimento econômico sustentável.

Que dizer, então, da crítica institucional? Não seria essa justiça baseada em direitos de desestabilização incompatível com o contexto de estabilidade e proteção dos direitos de propriedade necessário ao crescimento econômico? Imagino que estas notas conclusivas possam adiantar a resposta negativa a essa questão. De um lado, parece ser claro que a estabilidade institucional necessária ao desenvolvimento econômico não tem nada a ver com os mecanismos de reequilíbrio de poder viabilizados pelo modelo de ação política do direito vislumbrado acima. Ela refere-se, sobretudo, a um outro set de virtudes institucionais que não é incompatível com esse modelo, e que deveria, a bem da verdade, estar em sua base. É um set de virtudes que inclui respeito à autonomia dos agentes, racionalidade na aplicação do direito civil (jurisprudência uniforme e previsível) e respeito aos direitos de propriedade, mas que também implica coordenação estatal para a superação de problemas ligados à ação coletiva nos mercados e, sobretudo, redução de desigualdades e equalização das condições de participação política.

Ainda não há estudos econômicos bastantes capazes de responder ao modelo institucional do rule of law em contextos de subdesenvolvimento, sobretudo no que diz respeito ao viés conservador que parece estar, ao menos parcialmente, por trás desse 
modelo (basta garantir a propriedade e o desenvolvimento decorrerá naturalmente). Todavia, certos estudos já apontam o papel relevante de variáveis outras que devem, em um arranjo complexo, coordenarem-se à estabilidade institucional para a garantia do desenvolvimento humano. Pranab Bardhan ${ }^{620}$, por exemplo, indica que a construção de instituições capazes de garantir iguais oportunidades de participação política pode estar mais associada ao incremento de certos indicadores de desenvolvimento humano (alfabetização, por exemplo) que a própria proteção de direitos de propriedade. "Isso pode sugerir que alguns aspectos do desenvolvimento humano podem ser avançados tanto pelo progresso das instituições democráticas quanto pelo estabelecimento de mecanismos de proteção dos direitos de propriedade". ${ }^{621}$ Como tento sustentar nesta parte conclusiva do texto, pode haver, apesar de inúmeras outras deficiências institucionais, um papel importante das cortes de justiça no que diz respeito à amplificação desses mecanismos de equalização das condições de participação política na sociedade.

${ }^{620}$ Pranab Bardhan. Institutions Matter, but Which Ones? Economics in Transition, v. 13, n. 3, p. 499-532, 2005.

621 Idem, p. 503. 


\section{Resumo}

O Brasil tem assistido, a partir da abertura democrática em meados da década de 1980, a um intenso processo de judicialização da vida pública nacional. A falta de confiança nas instituições representativas, uma carta de direitos econômicos e sociais de tessitura ampla, o uso político freqüente do Judiciário pelas oposições e outros fatores relacionados parecem estar, todos, implicados nesse processo. A Justiça exerce hoje, no Brasil, um papel político importante, mas esta é apenas uma de suas faces. Ela é também inacreditavelmente ineficiente como prestadora de serviços e desempenha de forma inadequada a maior parte de suas funções ligadas à solução de disputas e à cobrança de créditos. Nesse contexto, as críticas feitas à expansão do papel político do Judiciário são abundantes. Em primeiro lugar, diz-se que essa expansão geraria um tipo de instabilidade institucional que, a seu turno, criaria um ambiente hostil ao crescimento econômico. Em segundo lugar, diz-se que ela é ilegítima, pois juízes politizados freqüentemente substituem decisões majoritárias por suas próprias preferências. Em terceiro lugar, diz-se que o contencioso judicial envolvendo questões políticas e de reforma social tende a ser errático e inefetivo, pois os desenhos institucionais próprios às cortes de justiça e a seus processos não são adequados à regulação de conflitos policêntricos e prospectivos. Este trabalho procura contextualizar o processo brasileiro de judicialização, analisando também os principais argumentos da crítica de incapacidade institucional (aqui chamada crítica instrumental). $\mathrm{O}$ autor sugere que a crítica instrumental refere-se a um certo modelo de direito e de justiça que tem estado em transformação (tanto no plano global como nacional) desde o final do século passado. No modelo emergente, a justiça distributiva é reintroduzida nas dinâmicas próprias ao direito, e a administração de interesses difusos paulatinamente sobrepuja a tutela de direitos individuais como modelo paradigmático de ação judiciária. Essas mudanças no direito e na justiça, junto com a judicialização, têm levado, afirma-se, a importantes alterações no processo judicial no Brasil. Apesar dos vários problemas ligados a essas alterações, as considerações finais deste trabalho apontam para um possível caráter virtuoso do novo contencioso brasileiro de direito público. Como afirmado aqui, esse contencioso parece estar criando um mecanismo de reforço de participação política que, a longo prazo, pode avançar o exercício da democracia e amplificar condições de igualdade política. 


\section{Abstract}

From democratization in the mid $80^{\prime}$ on, Brazilian public life has been forced into an increasingly intense process of judicialization. Lack of confidence in representative institutions, a very open-texted charter of social and economic rights, an important political use of the Judiciary by the oppositions, and other related factors seem to be implicated in this. Brazilian justice holds today a considerable political power, but that is just part of a story. It is also astonishingly inefficient as a services provider, and fails to respond to most of its dispute-solving and credit-enforcement functions. Criticism about the expansion of the political role of the Judiciary in this context is profuse. First, it is said to generate institutional instability, which in turn would bring out a hostile environment for economic growth. Second, it is said to be illegitimate, as far as politicized judges may often replace majoritarian decisions by their own. Third, it is said that litigation involving political issues and social reform tend to be erratic and ineffective, because the institutional designs of both courts and their processes are not adequate to regulate polycentric and prospective conflicts. This work puts Brazilian judicialization into context, and analyses the main arguments of the institutional capacity critique (which is called in here the instrumental critique). The author suggests that the instrumental critique refers to a certain model of law and justice that has been changing (both globally and in Brazil) since the end of the last century. In the emergent model, distributive justice is reintroduced into the dynamics of law, and the administration of diffuse interests slowly replaces the adjudication of individual rights as the paradigmatic activity of the Judiciary. Those changes in both law and justice, along with judicialization, are argued to have lead to other important changes in the design of the judicial process in Brazil. Despite the many problems related to those changes, the ending notes of this work point to a possible virtuous character of the new Brazilian public law litigation. As stated herein, this litigation seems to be creating a participation-reinforcing device that in the long run may foster democracy and political equality. 


\section{Sommaire}

Depuis l'ouverture démocratique passée pendant la moitié des années 1980, le Brésil passe par un intense procès de judicialisation de la vie publique nationale. Le manque de confiance aux institutions représentatives, une carte de droits économiques et sociaux de large portée, l'utilisation politique très fréquente de la justice par les oppositions et encore d'autres aspects pareils se montrent tous présents dans cette évolution. La Justice joue aujourd'hui au Brésil un rôle politique important, mais cela n'est qu'une de ses facettes. Elle est bien sûre incroyablement inefficace comme service prestataire et joue d'une façon déficiente la majorité de ses fonctions de solutions des disputes et charge de créances. Dans ce contexte, les critiques faites contre l'expansion du rôle politique de la Justice sont profuses. Premièrement, on dit que cette expansion entraînerait une sorte d'instabilité institutionnelle que à la fois déclencherais un ambiance hostile au développement économique. Ensuite, on dit qu'elle manque légitimité parce que des juges politisés fréquemment remplacent des décisions majoritaires par leurs propres préférences. Finalement, on dit que le contentieux judiciaire sur des affaires politiques et sur des questions de transformation sociale est inévitablement erratique et inefficace parce que le dessin institutionnel propre aux tribunaux judiciaires et à leur procès n'est pas juste à régler des conflits prospectifs et polycentriques. Cette thèse essaie de mettre en contexte le procès brésilien de judicialisation, en analysant aussi les arguments centraux de la critique d'incapacité institutionnelle (qu'on appelle ici la critique instrumentale). L'auteur suggère que la critique instrumentale travaille sur un modèle de droit et justice en transformation (dans le plan global aussi bien que dans le plan national) depuis la fin du siècle dernier. Dans le modèle émergent, la justice distributive est remise aux dynamiques juridiques, et l'administration des intérêts diffus surmonte l'adjudication de droits individuels comme modèle paradigmatique d'action judiciaire. On dit que cette transformation au seins de droits et de la justice, au delà de la judicialisation, sont en train de provoquer des importants changements aux procès judiciaires brésilien. Malgré les plusieurs problèmes liés à cette transformation, les considérations conclusives de cette thèse indiquent un possible aspect vertueux de ce neuf contentieux brésilien de droit public. D'après l'auteur, ce contentieux semble en train de créer un mécanisme de renforcement de participation politique qui à la fin peut faire avancer la démocratie et faciliter des conditions d'équité politique. 


\section{Índice remissivo}

2a Vara Criminal e Seção da Infância e Juventude da Comarca de Taubaté, Representação n. 193/2000 ............ 161 Ação civi pública. 69, 101, 186, 190, 205, 209

Adjudicação13, 14, 19, 27, 41, 66, 86, 87, $88,89,90,91,92,94,108,128,130$, $131,133,134,135,139,197,202,226$ Alemanha. $27,29,30,59,78$

Alexander Sprunt \& Sons, Inc. v. United States 166

América Latina. 59, 60, 61, 64, 65, 66, 14 Amicus curiae..... 157, 159, 163, 173, 194 Anteprojeto de Código Brasileiro de

Processos Coletivos ...... 176, 204, 213 Argentina ..............60, 61, 62, 63, 11, 23

Argüição de relevância 150

Assoc. of Data Processing Serv. Org., Inc v. Camp 167

Associated Industries of New York State, Inc. v. Ickes 166

Áustria. .78

Banco Mundial ............60, 64, 65, 66, 81 Bem comum .. 33, 77, 101, 105, 108, 164, $180,181,184,185,193,195,222,224$, 231,233

Blackmun, Harry 170,171

Brasil....11, 14, 27, 31, 35, 44, 55, 60, 62, $63,64,66,67,68,69,70,72,73,74$, $80,81,82,83,84,94,98,100,102$, $115,124,134,140,150,151,162,171$, 186, 190, 191, 192, 196, 197, 209, 218, $221,222,224,230,233,234,237,13$, $15,22,23,24,28$

Brown v. Board of Education . 47, 48, 49, $50,51,52,87$
Castelo Branco, Humberto de Alencar 61, 208

Chile 63,13

Ciência política 20, 22, 23, 24, 74, 77, 89, $95,109,178$

Class actions $62,189,202$

Código de Processo Civil ....99, 149, 156, 157, 158, 164, 192, 200, 208, 213

Código de Processo Civil Português .. 192 Coisa julgada. 85, 98, 100, 101, 102, 107, 137, 148, 199, 200

Colômbia. 63

Comando e controle.... 110, 145, 227, 228

Conflitos bilaterais $77,94,131$

Conflitos policêntricos. 77, 85, 90, 91, 92, 94, 101, 103, 114, 122, 131, 195, 237

Conflitos políticos . 11, 16, 17, 19, 76, 84, $85,86,128$

Constituição Americana 32

Constituição de 1988. 101, 146, 147, 151, 152, 153, 155, 186, 189, 206

Constituição de Weimar 29

Constituição Federal, art. $1^{\circ}$, inciso VI 127

Constituição Federal, art. $5^{\circ}$, incisos LIV e seguintes 151

Constituição Federal, art. $5^{\circ}$, XXI...... 151

Constituição Federal, art. $6^{\circ}$ 127

Constituição Federal, art. 23, inciso VI

Constituição Federal, art. 24, X 151

Constituição Federal, art. 62, parágrafo $1^{\mathrm{o}}, \mathrm{I},(\mathrm{b})$ 207

Constituição Federal, art. 92 a 135..... 151

Constituição Federal, art. 103 ............. 151

Constituição Federal, art. 127 ............ 150

Constituição Federal, art. 129 ............ 150

Constituição Federal, art. 227 ............ 162 
Constituição Federal, art. 153, parágrafo

$2^{\mathrm{o}}, \mathrm{I}$. 123 128

Constituição Italiana, art. 103 127

Constituição Mexicana de 1917 ...........29

Contenção judicial .................................8 80

Convenção da Filadélfia .......... 23, 32, 35

Cortes de justiça .... 12, 13, 15, 16, 18, 19, $20,22,24,25,29,30,31,32,34,36$, $40,44,46,50,51,52,59,60,64,66$, $76,77,79,80,94,95,98,103,123$, $128,136,140,142,152,162,233,235$, 236, 237

Costa Rica 24,63

Crítica instrumental14, 19, 52, 77, 84, 85, $86,87,94,95,96,101,102,107,108$, $110,111,125,126,128,136,138,216$, $217,219,233,237$

Declaração Universal dos Direitos do Homem. 57

Decreto Lei no 119 -A, de 07 de janeiro de 1890 169

Déficits de informação............... 123, 124

Dificuldade contra-majoritária. 34, 51, 80

Direito subjetivo.. 19, 77, 85, 95, 99, 102, $125,126,128,129,130,131,132,133$, $134,135,136,137,138,159,163,164$, $165,167,170,172,174,175,193$

Direitos sociais 46, 51, 60, 61, 62, 63, 94, 106, 107, 135, 221

Douglas, William........169, 170, 171, 172

Dred Scott v. Sandford ...... 40, 45, 46, 51

Earl Warren .50

Emenda Constitucional n. 32, de 11 de setembro de 2001 207, 209

Emenda Constitucional n. 45/04 207, 214

Estado Social 27, 28, 50, 69, 89, 106, 140

Estados Unidos 22, 23, 27, 28, 31, 35, 36, $37,41,44,45,49,50,51,52,61,65$, $75,78,79,142,145,146,157,165$, 168, 198, 227

Europa.......... 30, 52, 53, 58, 59, 65, 192

FCC v. Sanders Brothers 166

Figueiredo, João Baptista de Oliveira ..61

Filosofia política. 109

França ..... 23, 41, 42, 43, 53, 54, 78, 189 Conseil Constitutionnel..30, 43, 44, 54, 57

Conselho de Estado 57

Franklin D. Roosevelt 46,61
Geisel, Ernesto 61 Gestão de interesses.......11, 19, 135, 140, $147,148,165,168,171,196,202,205$, 217

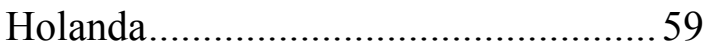

Hungria ................................................ 58

Instituições judiciárias68, 70, 72, 74, 108, 138

Interesse público 127, 131, 139, 159, 169, $172,173,175,196,203,204,205,208$, 222, 223, 227, 233

Interesses....17, 19, 20, 28, 33, 36, 44, 46, $50,56,67,69,70,74,88,91,92,97$, $99,100,102,106,109,126,127,128$, $129,130,131,132,133,134,135,136$, $137,138,140,141,143,147,155,156$, $157,159,165,167,168,169,170,171$, $172,173,174,175,176,177,178,179$, 184, 185, 186, 187, 188, 189, 190, 191, 192, 193, 195, 196, 197, 198, 200, 203, 204, 205, 210, 213, 218, 222, 223, 224, $225,226,227,228,229,230,231,232$, $233,234,235,237$

Itália $24,27,78,175,189$

John G. Roberts, Jr. 50

Judicialização da política...11, 14, 23, 24, $25,26,28,30,31,57,63,67,68,69$, $70,74,75,13$

Justiça comutativa ...... 104, 105, 106, 163 Justiça distributiva19, 104, 105, 106, 107, $109,111,112,120,125,130,131,132$, 193, 237

Justiça retributiva 19, 105, 106, 114, 117, 122, 210

Kevin Armstrong et al., Jeffrey Jackson et al. V. Board of School Directors of the City of Milwaukee 205

Law and development. 65

Leal, Victor Nunes 61

Legislação dos EUA Consumer Credit Protection Act ...... 28 National Environmental Policy Act . 28

Lei n. 10.352, de 26 de dezembro de 2001 158

Lei n. 10.358, de 27 de dezembro de 2001 158

Lei n. 10.444, de 7 de maio de 2002 .. 158

Lei n. 11.232, de 22 dezembro de 2005 158,200

Lei n. 4.348 de 26 de junho de 1964 .. 208 
Lei n. 4.717, de 29 de junho de 1965.155

Lei n. 6.938, de 31 de agosto de $1981 . .28$

Lei n. 7.347 , de 24 de julho de 1985 ...28, 69,155

Lei n. 7.853, de 24 de outubro de 1989

156

Lei n. 7.913, de 7 de dezembro de 1989

155

Lei n. 8.069, de 13 de julho de $1990 . .156$

Lei n. 8.076, de 23 de agosto de 1990208

Lei n. 8.078, de 11 de setembro de 1990 $28,69,156$

Lei n. 8.437, de 30 de junho de 1992 206, 208

Lei n. 8.455, de 24 de agosto de 1992156

Lei n. 8.718, de 14 de outubro de 1993

Lei n. 8.884, de 11 de junho de 1994 157, 176

Lei n. 8.950, de 13 de dezembro de 1994

157

Lei n. 8.951, de 13 de dezembro de 1994

157

Lei n. 8.952, de 13 de dezembro de 1994

157

Lei n. 8.953, de 13 de dezembro de 1994

157

Lei n. 9.099, de 26 de setembro de 1995

206

Lei n. 9.139, de 30 de novembro de 1995

157

Lei n. 9.472 , de 16 de julho de $1997 \ldots .27$

Lei n. 9.494, de 10 de setembro de 1997 206, 208

Lei n. 9.868, de 10 de novembro de 1999 157,173

Lei n. 9.882, de 3 de dezembro de 1999 157,158

Lima, Hermes de 61

Limongi, Celso 153

Lochner v. People of State of New York $34,40,46$

Lujan v. Defenders of Wildlife .. 168, 170

Magistratura $43,69,189,223$

Marbury v. Madison ....24, 32, 37, 38, 39, 40, 41, 44, 68, 80

Medida Provisória n. 1.984-14, de janeiro de 2000 209

Medida Provisória n. 1.570, de 27 de março de 1997 208, 209
Medida Provisória n. 1.798, de 11 de fevereiro de 1999. 206

Medida Provisória n. 182, de 23 de abril de 1990. 208

Medida Provisória n. 198, de 26 de julho de 1990. 208

Medida Provisória n. 2.180-35, de 24 de agosto de 2001............................... 209

Mello, Fernando Collor de................ 208

Ministério Público...69, 70, 83, 147, 148, $150,153,154,155,156,160,161,162$, $171,172,173,175,176,177,178,186$, $187,188,189,190,191,192,197,201$, 204, 205, 213, 217, 221, 223, 234, 235, $13,16,24$

Posição ideológica............................ 70

Miranda v. Arizona ............................. 51

New Deal ............................. 46, 61, 68

Pacto Internacional de Direitos

Econômicos, Sociais e Culturais ...... 28

Plano Bresser 215

Plano Collor $18,75,208,215$

Plano Verão. 215

Plessy v. Ferguson................................ 48

Poder Executivo .... 12, 24, 26, 27, 28, 54, 68, 71, 74, 101, 176, 207, 209

Poder Judiciário1 1, 12, 13, 14, 15, 16, 17, $22,23,24,28,29,30,31,32,34,35$, $36,40,42,43,57,59,60,61,63,64$, $66,67,68,71,72,73,74,76,78,81$, $83,84,85,95,96,99,103,104,105$, $106,107,108,111,115,127,139,140$, $141,147,149,150,151,152,153,154$, $156,159,162,164,189,193,203,207$, $210,212,214,215,217,218,219,221$, $222,224,225,231,234,21$

Poder Legislativo .. 12, 21, 26, 45, 70, 71, 73, 74, 101, 167, 188, 203, 10

Políticas públicas... 16, 18, 19, 24, 26, 28, $50,63,67,69,71,73,75,77,84,95$, $96,97,98,103,115,170,207,221$, 222, 223, 225, 226

Portugal. 27,176

Princípio da adstrição 17, 18, 85, 137, 196

Processo judicial.... 11, 19, 48, 69, 77, 85, $86,97,98,124,126,142,143,147$, 148, 158, 169, 197, 204, 205, 211, 217, 226, 230, 237

Procuradoria Geral da República ......... 71

Projeto de Lei n. 94/02 203 
Prova......52, 79, 110, 124, 125, 138, 141, 148, 156, 159, 170, 192, 193, 197, 198, 202

Reforma do Estado 18

Roe v. Wade $75,78,79$

Rule of law..... 29, 59, 60, 64, 65, 66, 235

Segunda Guerra Mundial........ 19, 27, 52

Sentença .... 17, 83, 85, 97, 100, 107, 130, $137,141,143,146,158,196,202,209$, 211

Separação de poderes...23, 52, 73, 76, 80, 84, 100, 154, 170, 206, 209, 219, 220

Sierra Club v. Morton. 168

Silva, Artur da Costa e. .61

Silva, Evandro Lins e. 61

Sociedade civil ....62, 69, 70, 74, 75, 151, 157, 187, 201, 222, 231

Structural reform $49,61,140,160$

Suécia $24,59,189$

Superior Tribunal de Justiça ... 70, 83, 84, 124, 151, 152, 162, 209, 212, 213

Superior Tribunal de Justiça, AgRg na Suspensão de Liminar $\mathrm{N}^{\mathrm{o}} 57$ .84

Superior Tribunal de Justiça, Conflito de Competência n. 39.590 162,213

Superior Tribunal de Justiça, Conflito de Competência n. 9.686 212

Superior Tribunal de Justiça, Conflito de Competência n. 971-DF 209

Superior Tribunal de Justiça, Suspensão de Segurança n. 1.408 124,162

Suprema Corte americana..23, 24, 32, 35, $36,37,38,39,40,41,44,45,46,47$, $48,49,50,51,61,63,65,68,73,78$, $79,80,142,165,166,167,168,169$, 170

Supremo Tribunal Federal .18, 41, 47, 61, 70, 71, 72, 74, 75, 76, 82, 101, 150,
$151,152,154,157,162,163,194,207$, 209, 213, 214, 215, 218, 10, 13, 28

Supremo Tribunal Federal, Ação Direta de Inconstitucionalidade $n$ 3.105..... 75

Supremo Tribunal Federal, Argüição de Descumprimento de Preceito

Fundamental n. 54 $.76,163,213$

Supremo Tribunal Federal, Recurso Extraordinário n. 226.855 75

Tradição liberal ..... 11, 77, 104, 108, 109, 124, 126, 138, 174, 196

Tribunal de Justiça das Comunidades Européias 24,58

Tribunal de Justiça do Estado de São Paulo, Agravo de Instrumento $\mathrm{n}$. 303.687-5/1-00 160

Tribunal de Justiça do Estado de São Paulo, Agravo de Instrumento n. 399.864-5/7-00 160

Tribunal de Justiça do Estado de São Paulo, Agravo Regimental n. 335.4015/9-01 163

Tribunal de Justiça do Estado de São Paulo, Apelação Cível no 37.609-0/5

Tutela judicial 48, 62, 141, 146, 148, 159, 170, 234

Tutelas provisórias 148

Uniformização da jurisprudência 149, 212

USAid .... 60

Vinculação pelo precedente ...... 149, 206, 210, 212

Ware v. Hylton....................................... 39

Warren Burger..................................... 50

Warren Court .........31, 49, 50, 51, 52, 68

Welfarismo................................... 29, 69

William Rehnquist............................. 50 


\section{Bibliografia}

ACKERMAN, Bruce. We the People : Volume 1, Foundations. Cambridge: Belknap Press, 1993.

ANDRADE, Maria Margarida de. Estratégias da impessoalidade nos discursos científico e tecnológico. Cadernos do Congresso Nacional de Lingüística e Filologia, Série VIII, n. 5. Disponível em: <http://www.filologia.org.br/viiicnlf/anais/ caderno05.html>. Acesso em 28 mar. 2005.

ANGELL, Alan; SIEDER Rachel; SCHJOLDEN, Line (ed.). Judicialization of Politics in Latin America. London: Palgrave Macmillan, 2005.

ARISTÓTELES, Ética a Nicômacos (trad. Mário da Gama Kury). 4. ed. Brasília: Universidade de Brasília, 2001.

BANCO NACIONAL DE DADOS DO PODER JUDICIÁRIO. Supremo Tribunal Federal. Disponível em: <http://www.stf.gov.br/bndpj/stf/RamoDireito.asp>. Acesso em 18 mar. 2005.

BARBOSA, Mariana G. O Supremo Tribunal Federal e a Política de Fornecimento de Medicamentos para Tratamento da AIDS. SOCIEDADE BRASILEIRA DE DIREITO PÚBLICO, São Paulo: 2005. Monografia apresentada como requisito parcial de conclusão de curso. Mimeo.

BARDHAN, Pranab. Institutions Matter, But Which Ones? Economics in Transition, v. 13, n. 3, p. 499-532, 2005. 
BEDAQUE, José Roberto dos Santos. Poderes Instrutórios do Juiz. 3. ed., São Paulo: Revista dos Tribunais, 2001.

- Tutela Cautelar e Tutela Antecipada: Tutelas Sumárias e de Urgência (tentativa de sistematização). São Paulo: Malheiros, 1998.

. Direito e Processo. 2. ed., São Paulo: Malheiros, 1997.

. Discricionariedade judicial. Revista Forense, v. 97, n. 354, p.187-95, 2001.

. Efetividade do Processo e Técnica Processual: Tentativa de Compatibilização. São Paulo: Universidade de São Paulo, 2005. Tese apresentada ao concurso para o cargo de Professor Titular de Direito Processual Civil, Faculdade de Direito, São Paulo.

BELL JR., Derick A. Serving Two Masters: Integration Ideals and Client Interests in School Desegregation Litigation. The Yale Law Journal, v. 85, 1976.

BENTHAM, Jeremy. The Principles of Morals and Legislation. Amherst: Prometheus Books, 1988.

BERGALLO, Paola. Justicia y experimentalismo: la función remedial del poder judicial en el litigio de derecho público en Argentina. In: SEMINARIO EN LATINOAMÉRICA DE TEORÍA CONSTITUCIONAL Y POLÍTICA, Rio de Janeiro, 16-19 jun. 2005. Trabalho apresentado. Disponível em: $<$ http://islandia.law.yale.edu/sela/sela2005.htm $>$.

BERIZONCE, Roberto Omar. Los medios alternativos de solucion de conflictos: bases para su implentacion. In: XV Congreso Mexicano de Derecho Procesal. Mexico: Instituto de Investigaciones Jurídicas, 1998. Disponível em: $<$ http://www.bibliojuridica.org/libros/2/745/13.pdf $>$.

BICKEL, Alexander M. The Least Dangerous Branch: the Supreme Court at the Bar of Politics. 2. ed. New Haven: Yale University Press, 1986. 
BLANKENBURG, Erhard. Changes in Political Regimes and Continuity of the Rule of Law in Germany, in JACOB, Herbert et al. (ed.), Courts, Law and Politics in Comparative Perspective. New Haven: Yale University Press, 1996.

BOARD, Joseph B. Judicial Activism in Sweden. In: HOLLAND, Kenneth M. (ed.). Judicial Activism in Comparative Perspective. New York: St. Martins's Press, 1991.

BOHMAN James; REHG, William (ed.). Deliberative Democracy: Essays on Reason and Politics. Boston: The MIT Press, 1997.

CADERNOS DO CENTRO DE ESTUDOS JUDICIÁRIOS DO CONSELHO DA JUSTIÇA FEDERAL, Brasília, vol. 22. Disponível em: <http://www. cjf.gov.br/revista/seriecadernos/vol22/artigo04.pdf>.

CAETANO Marcello, "Sobre o problema da legitimidade de partes no contencioso administrativo português", in Estudos de Direito Administrativo, Lisboa: Atica, 1974.

CAMPILONGO, Celso F. Direito e Democracia. 2. ed. São Paulo: Max Limonad, 2000.

CANTUARIAS, Fernando. Robin Hood Reloaded: Taking Money from the Rich to Steal from the Poor. In: SEMINARIO EN LATINOAMÉRICA DE TEORÍA CONSTITUCIONAL Y POLÍTICA, Rio de Janeiro, 16-19 jun. 2005. Trabalho apresentado. Disponível em: < http://islandia.law.yale.edu/sela/sela2005.htm>.

CAPPELLETTI, Mauro. Formações Sociais e Interesses Coletivos Diante da Judtiça Civil. Revista de Processo, n. 5, 1977.

. Juizes Legisladores? Porto Alegre: Sergio Antonio Fabris, 1993.

. O Controle de Constitucionalidade das Leis no Direito Comparado, 2. ed. Porto Alegre: Sergio Antonio Fabris, 1999.

. Public Interest Parties and the Active Role of the Judge in Civil Litigation. Milano: Giuffrè, 1975. 
. The 'Mighty Problem' Of Judicial Review And The Contribution Of Comparative Analysis. Southern California Law Review, V. 53, P. 409-SS, 1980.

CARNEIRO, Paulo Cezar Pinheiro. Acesso À Justiça: Juizados Especiais e Ação Civil Pública - uma Nova Sistematização da Teoria Geral do Processo. Rio de Janeiro: Forense, 1999.

CARNELUTTI, Francesco. Instituições de Processo Civil. Vol. 1. São Paulo: Classic Book, 2000.

CASTILHO, Ela Wiecko V. de; SADEK, Maria Tereza. O Ministério Público Federal e a Administração da Justiça no Brasil. São Paulo: Sumaré, 1998.

CASTRO, Marcus Faro de. O Supremo Tribunal Federal e a judicialização da política. Revista Brasileira de ciências Sociais, v. 12, n. 34, p. 147-156, 1997.

CHAYES, Abram. The Role of the Judge in Public Law Litigation. Harvard Law Review, v. 89, p. 1281-ss., 1975-1976.

CHIOVENDA, Giuseppe. Instituições de Direito Processual Civil. Tomo I. Campinas: Bookseller, 2000.

COHEN, G. A. If You're an Egalitarian, How Come You're So Rich? Cambridge: Harvard COMPARATO, Fábio K. A Afirmação Histórica dos Direitos Humanos. 4. ed. São Paulo: Saraiva, 2005. . 1984. Folha de São Paulo, São Paulo, 14 jun. 2000. Caderno A, p. 3.

COSTA, Susana Henriques da. Condições da Ação. São Paulo: Quartier Latin, 2005.

COUSO, Javier A. The Politics of Judicial Review in Chile in the Era of Democratic Transition, 1990-2002, in GLOPPEN, Siri; GARGARELLA, Roberto; SKAAR, Elin (ed.). Democratization and the Judiciary. Portland: Franck Cass, 2004.

CROUCH, Ben M.; MARQUART, James W. An Appeal to Justice: Litigated Reform of Texas Prisons. Austin: University of Texas Press, 1989. 
DAHL, Robert A. A Preface to Democratic Theory. Chicago and London: The University of Chicago Press, 1963.

. Decision-Making In A Democracy: The Supreme Court As A National PolicyMaker. Journal of Public Law, v.6, p. 279-ss., 1957.

. Pluralism Revisited. Comparative Politics, v. 10, n. 2, p. 191-203, 1978.

DAKOLIAS, Maria. Court Performance Around the World: a Comparative Perspective. World Bank Technical Paper, n. 430, 1999. Disponível em: <http://wwwwds.worldbank.org/servlet/WDSContentServer/WDSP/IB/1999/09/25/000094946_ 99090805303789/Rendered/PDF/multi_page.pdf $>$.

DALLARI, Dalmo de Abreu. Caricatura Jurídica. Folha de São Paulo, São Paulo, 24 abr. 1997. Caderno 1, p. 3.

DAMAŠKA, Mirjan R. Adversary Presentation of Evidence and Factfinding Precision. University of Pennsylvania Law Review, v. 123, p. 1082-1106, 1975.

. The Faces Of Justice And State Authority: A Comparative Approach To The Legal Process. New Haven: Yale University Press, 1986.

DAVIS, Keneth C. The Liberalized Law of Standing. University of Chicago Law Review, v. 37, p. 450-ss, 1970.

DENTI, Vittorio. La Giustizia Civile (Lezioni Introduttive). Bologna: Mulino, 1989.

DIÁRIO DE SÃO PAULO. Promotoria Faz Acordo Para Criar Mais Vagas Em Escolas. Diário de São Paulo, São Paulo, 4 jan. 2006.

DINAMARCO, Cândido R. A Instrumentalidade do Processo. $5^{\mathrm{a}}$ ed., São Paulo: Malheiros, 1996.

. As Função das Cortes Supremas na América Latina. Revista Forense, n. 342, p. 3-12, 1998.

. O Futuro do Processo Civil Brasileiro. In: Fundamentos do Processo Civil Moderno. 3. ed. São Paulo: Malheiros, 2000. 
. Relativizar a Coisa Julgada Material. Revista da Procuradoria Geral do Estado de São Paulo, n. 55/56, p. 29-77, 2001. Disponível em: $<$ http://www.pge.sp.gov.br/centrodeestudos/revistaspge/2001>.

. Universalizar a Tutela Jurisdicional. In: Fundamentos do Processo Civil Moderno. 3. ed. São Paulo: Malheiros, 2000.

DIVER, Colin S. The Judge as a Political Powerbroker: Superintending Structural Change in Public Institutions. Virgínia Law Review, v. 65, n. 1, p. 43-106, 1979.

DWORKIN, Ronald. A Matter of Principle. Cambridge: Harvard University Press, 1986. . Law as Interpretation. Texas Law Review, v. 60, p. 527-43, 1982.

. Law’s Empire. Cambridge: Harvard University Press, 1986.

. Taking Rights Seriously. Cambridge: Harvard University Press, 2005.

ELSTER, Jon. A Possibilidade da Política Racional. Revista Brasileira de Ciências Sociais, v. 14, n. 39, 1999.

ELY, John H. Democracy and Distrust: A Theory of Judicial Review. Cambridge: Harvard University Press, 1980.

EPSTEIN, Lee; KNIGHT, Jack; MARTIN, Andrew. The Supreme Court as a Strategic Nacional Policymaker. Emory Law Journal, v. 50, p. 583-ss., 2001.

ESKRIDGE JR. William N. Pluralism and Distrust: How Courts Can Support Democracy by Lowering the Stakes of Politics. The Yale Law Journal, v. 114, p. 1279-1328, 2005.

FALCÃO, Joaquim de Arruda. Justiça Social e Justiça Legal: Conflitos de Propriedade no Recife. In: FALCÃO, Joaquim de Arruda (org.). Conflito de Direito de Propriedade - Invasões Urbanas. Rio de Janeiro: Forense, 1984.

FARIA, José Eduardo C. de O. Direito e Justiça no Séc. XXI: A crise da Justiça no Brasil. In: COLÓQUIO DIREITO E JUSTIÇA NO SÉCULO XXI, Coimbra, 29-31 mai. 
2003. Disponível em: <http://opj.ces.uc.pt/portugues/novidds/comunica/ JoseEduarFaria.pdf >. Acesso em 22 abr. 2005.

FEDERICO, Giuseppe di. Italy: A Peculiar Case. In: TATE, C. Neal; VALLINDER, Tobjörn (ed.). The Global Expansion of Judicial Power. New York: New York University Press, 1995.

FEREJOHN, John. Judicializing Politics, Politicizing Law. Law and Contemporary Problems, v. 65, n. 3, p. 41-ss, 2002.

FERRAZ, Antonio A. M. C. Ação Civil Pública, Inquérito Civil e Ministério Público. In: MILARÉ, Edis (coord.). Ação Civil Pública, 15 anos. 2. ed. São Paulo: Revista dos Tribunais, 2002.

FINKELMAN, Paul. The Dred Scott Case, Slavery and the Politics of Law. Hamline Law Review, v. 20, p. 1-ss., 1996.

FISH, Stanley. Fish v. Fiss. Stanford Law Review, v. 36, p. 1325-ss, 1983. . Interpretation and the Pluralist Vision. Texas Law Review, v. 60, p. 495-505, 1982.

. Is There a Text in This Class?: The Authority of Interpretive Communities. Cambridge: Harvard University Press, 2005.

. Working on the Chain Gang: Interpretation in the Law and in Literary Criticism. Critical Inquiry, v. 9, p, 201-216, 1982.

FISS, Owen M. e Judith Resnik, Adjudication And Its Alternatives (An Introduction To Procedure). New York: Foundation Press, 2003.

FISS, Owen M. Against Settlement. The Yale Law Journal, v. 93, p. 1073-ss., 1984. . Conventionalism. Southern California Law Review, v. 58, p. 177-197, 1985. . Objectivity and Interpretation. Stanford Law Review, v. 34, p. 739-763, 1982. . The Civil Rights Injunction. Bloomington: Indiana University Press, 1978. 
. The Forms of Justice. Harvard Law Review, v. 93, n. 1, p. 1-ss., 1979.

. The Political Theory of the Class Action. Washington and Lee Law Review, v. 53, p. 21-31, 1996.

. The Right Degree of Independence. In: STOTZKY, Irwin P. Transition to Democracy in Latin America: The Role of the Judiciary, San Francisco: Westwiew Press, 1993.

- Um Novo Processo Civil: Estudos Norte-Americanos sobre Jurisdição, Constituição e Sociedade. Coord. Trad. Carlos Alberto de Salles. São Paulo: Revista dos Tribunais, 2004.

FOLHA DE SÃO PAULO. Advogado-Geral Diz que Regras da MP Já São Aceitas. Folha de São Paulo, São Paulo, 09 jul. 2000. Caderno A, p. 11.

. FHC Muda as Regras do Jogo. Folha de São Paulo, São Paulo, 09 jul. 2000. Caderno A, p. 11.

. Leilão do Banespa Vai Ser Adiado Pela Terceira Vez. Folha de São Paulo, São Paulo, 10 jun. 2000. Caderno B, p. 3.

. MP de Março Renova Polêmica. Folha de São Paulo, São Paulo, 05 abr. 1997. Caderno 3, p. 2.

FRANK, Jerome. Law and the modern mind. New York: Doubleday \& Co., $1963 .$.

FREIRE, Nilcéa. Entrevista Concedida ao Programa Roda Viva. São Paulo, TV Cultura, 21 mar. 2005.

FREITAS, Silvana de. Associação de Juízes Protesta Contra MP. Folha de São Paulo, São Paulo, 04 abr. 1997. Caderno 1, p. 15.

- Governo Cria Regras que o Favorecem em Batalhas Judiciais. Folha de São Paulo, São Paulo, 09 jul 2000. Caderno A, p. 11.

. STF dá Vitória a Governo Sobre Liminares. Folha de São Paulo, São Paulo, 17 abr. 1997. Caderno 1, p. 15. 
FRIED, Charles. Right and Wrong. Cambridge: Harvard University Press, 1978.

FRIEDMAN, Barry. The History of the Countermajoritarian Difficulty (Part 1): The Road to Judicial Supremacy. New York University Law Review, v. 73, p. 333-ss, 1998.

. The History of the Countermajoritarian Difficulty (Part 2): Reconstruction's Political Court. Georgetown Law Review, v. 91, p. 1-ss., 2002.

. The History of the Countermajoritarian Difficulty (Part 3): The Lesson of Lochner. New York University Law Review, v. 76, p. 1383-ss., 2001.

. The History of the Countermajoritarian Difficulty (Part 4): Law's Politics. University of Pennsylvania Law Review, v. 148, p. 971-ss, 1999-2000.

. The History of the Countermajoritarian Difficulty (Part 5): Birth of an Academic Obsession. The Yale Law Journal, v. 112, p. 153-ss., 2002-2003.

FRIEDMAN, Lawrence M. Total Justice. New York: Russell Sage Foundation Publications, 1994.

FÜLLER, Lon. The Forms and Limits of Adjudication. Harvard Law Review, v. 92, p. 353-ss., 1978-1979.

GALANTER, Marc. The Emergence of the Judge as a Mediator in Civil Cases. Judicature, v. 69 , n. 5 , p. $257-$-ss, 1986.

. Why the 'Haves' Come Out Ahead: Speculations on the Limits of Legal Change. Law \& Society Review, v. 9, n. 1, p. 95-160, 1974.

GARNER, Bryan A. (ed.). Black's Law Dictionary. 8. ed. St. Paul: West Publishing Co., 2004.

GARTH, Bryant G. Building Strong and Independent Judiciaries Through the New Law and Development: Behind the Paradox of Consensus Programs and Perpetually Disappointing Results. Depaul Law Review, v. 52, p. 384-ss., 2002. 
GINSBURG, Tom. Economic Analysis and the Design of Constitutional Courts. Theoretical Inquiries in Law (Online Edition), v. 3, n. 1, Article 3, 2002. Disponível em: < http://www.bepress.com/til/default/vol3/iss1/art3>.

GLOPPEN, Siri; GARGARELLA, Roberto; SKAAR, Elin (ed.). Democratization and the Judiciary. Portland: Franck Cass, 2004. . Introduction: The Accountability Function of the Courts in New Democracies. In: . (ed.), Democratization and the Judiciary. Portland: Franck Cass, 2004.

GRAU, Eros R. O Direito Posto e o Direito Pressuposto. São Paulo: Malheiros, 1996.

GRAZIANO, Luigi. O Lobby e o Interesse Público. Revista Brasileira de Ciências Sociais, v. 12 , n. $35,1997$.

GRINOVER, Ada P. Da Class Action for Damages à Ação de Classe Brasileira: os Requisitos de Admissibilidade. Revista de Processo, v. 101, p. 11-27, 2001.

GROSSMAN, Joel B. Judicial Legitimacy and the Role of Courts: Shapiro's Courts. American Bar Foundation Research Journal, n. 1, p. 217-ss., 1984.

GUARNIERI, Carlo. Judicial Independence and Policy-Making in Italy. In: TATE, C. Neal; VALLINDER, Tobjörn (ed.). The Global Expansion of Judicial Power. New York: New York University Press, 1995.

GUTMANN, Amy. A Desarmonia na Democracia. Lua Nova, n. 36, p. 5-37, 1995.

HABERMAS, Junger. Direito e Democracia: entre Faticidade e Validade. Rio de Janeiro: Tempo Brasileiro, 1997.

HAMILTON, Alexander et al. The Federalist. Cambridge: Hackett Publishing Company, 2005.

HARLOW, Carol. Public Law and Popular Justice. Mod. L. Rev., v. 65, p. 1-ss., 2002.

HAYEK, Friedrich. The Constitution of Liberty, London: Routledge and Kegan Paul, 1960. 
HAZARD JR., Geoffrey C. Rising Above Principle. University of Pennsylvania Law Review, v. 135, p. 153-ss., 1986-1987.

HENDLEY, Kathryn. Business Litigation in the Transition: A Portrait of Debt Collection in Russia. Law \& Society Review, v. 38, n. 2, p. 305-47, 2004.

HOLMSTRÖM, Barry. Sweden. In: TATE, C. Neal; VALLINDER, Tobjörn (ed.). The Global Expansion of Judicial Power. New York: New York University Press, 1995.

HOROWITZ, Donald L. The Courts and Social Policy. Washington: The Brookings Institution, 1977.

JORNAL DO BRASIL, Rio de Janeiro, p. 13-14, 2 mai. 1997

KATE Jan Ten; and KOPPEN, Peter J. Van. The Netherlands: Toward a Form of Judicial Review. In: TATE, C. Neal; VALLINDER, Tobjörn (ed.). The Global Expansion of Judicial Power. New York: New York University Press, 1995.

KEMERER, Frank. R. William Wayne Justice: A Judicial Biography. Austin: University of Texas Press: 1991.

KETCHAM, Ralph (ed.). The Anti-Federalist Papers and the Constitutional Convention Debates. New York: Signet Classics, 2003.

KOOPMANS, Tim. Courts and Political Institutions: A Comparative View. New York: Cambridge University Press, 2003.

KRITZER, Herbert M. Courts, Justice, and Politics in England. In: JACOB Herbert et al. (ed.). Courts, Law and Politics in Comparative Perspective. New Haven: Yale University Press, 1996,.

KYMLICKA, Will. Contemporary Political Philosophy. Oxford: Clarendon Press, 1990.

LAFON, Jacqueline Lucienne. France. In: TATE, C. Neal; VALLINDER, Tobjörn (ed.). The Global Expansion of Judicial Power. New York: New York University Press, 1995. 
LAMBERT, Edouard. Le Gouvernement des Juges et la Lutte Contre la Législation Sociale aux États-Unis: L'expérience Américaine du Contrôle Judiciaire de la Constitutionnalité des Lois. Paris: Marcel Giard, 1921.

LANDFRIED, Christine. Germany. In: TATE, C. Neal; VALLINDER, Tobjörn (ed.). The Global Expansion of Judicial Power. New York: New York University Press, 1995.

LIEBMAN, Enrico T. Manuale di Diritto Processuale Civile. 5. ed., Milano: Giuffrè, 1992.

LIJPHART, Arend. Modelos de Democracia: Desempenho e Padrões de Governo em 36 Países. Rio de Janeiro: Civilização Brasileira, 2003.

LIMONGI, Celso. Discurso de Posse no Cargo de Presidente da Associação Paulista dos Magistrados. Disponível em : <http://www.apamagis.com.br/noticias/lerNoticia2. php?id_new $=9>$.

LOPES, José Reinaldo Lima. As Palavras e a Lei: Direito, Ordem e Justiça na História do Pensamento Jurídico Moderno. São Paulo: Editora 34, 2004.

. Juízo Jurídico e a Falsa Solução dos Princípios e das Regras. Revista de Informação Legislativa, v. 40, n. 160, 1993.

. Justiça e Poder Judiciário ou a Virtude Confronta a Instituição. Revista USP, n. 21, pp. 22-33, 1994.

. O Direito na História. São Paulo: Max Limonad, 2000.

MACEDO JR., Ronaldo Porto. Contratos Relacionais e Defesa do Consumidor. São Paulo: Max Limonad, 1998.

MANCUSO, Rodolfo de Camargo. Ação Civil Pública. $6^{\mathrm{a}}$ ed., São Paulo: Revista dos Tribunais, 1999.

MANDEL, Michael. Legal Politics Italian Style. In: TATE, C. Neal; VALLINDER, Tobjörn (ed.). The Global Expansion of Judicial Power. New York: New York University Press, 1995. 
MARQUES NETO, Floriano Peixoto de Azevedo. Regulação Estatal e Interesses Públicos. São Paulo: Malheiros, 2002.

MASHAW, Jerry L.; MERRILL, Richard A.; SHANE, Peter M. Administrative Law: The American Public Law System, Cases and Materials (American Casebook Series). St. Paul: West Group, 1998.

MAURINO, Gustavo; NINO Ezequiel; SIGAL, Martín. Acciones Colectivas: Análisis Conceptual, Constitucional, Jurisprudencial, Procesal y Comparado. Buenos Aires: Editorial Lexis Nexis, 2005.

MEDAUAR, Odete. A Processualidade no Direito Administrativo. São Paulo: Revista dos Tribunais, 1993.

MESQUITA, José Ignácio Botelho de. As novas tendências do direito processual: uma contribuição para seu reexame. Revista Forense, v. 361, 2002.

MILL, John Stuart. Utilitarianism. 2. ed. Cambridge: Hackett Publishing Company, 2002.

MOLOT, Jonathan T. An Old Judicial Role for a New Litigation Era. The Yale Law Journal, v. 113, n. 1, p. 95-ss., 2003.

NAGEL, Thomas. Equality and Partiality. New York: Owford University Press, 1991. . Objectivity. In: . Mortal Questions. Cambridge: Cambridge University Press, 1992.

NELSON, William E. Marbury v. Madison: The Origins and Legacy of Judicial Review (Landmark Law Cases and American Society.) Lawrence: University Press of Kansas, 2000.

NONET, Philippe; SELZNICK, Philip. Law and Society in Transition: Towards Responsive Law. New York: Harper \& Row, 1978.

NORTH, Douglas C. Institutions, Institutional Change, and Economic Performance. New York: Cambridge University Press, 1990.

NOZICK, Robert. Anarchy, State and Utopia. New York: Basic Books, 1974 
OlIVEIRA, Ana Carolina C. de et al. O Judiciário e as Políticas Públicas de Saúde no Brasil: o Caso AIDS. São Paulo: 2004. Monografia apresentada ao Instituto de Pesquisa Econômica Aplicada. Disponível em: < www.ipea.gov.br/SobreIpea/ 40anos/estudantes/monografiacamila.doc $>$.

OLSON, Mancur. The Logic of Collective Action: Public Goods and the Theory of Groups. Cambridge: Harvard University Press, 2002.

OSIEL, Mark J. Dialogue with Dictators: Judicial Resistance in Argentina and Brazil. Law \& Soc. Inquiry, v. 20, p. 481-ss., 1995.

OST, François Entre droit et non-droit, l'intérêt. Essai sur les fonctions qu'exerce la notion d'intérêt en droit privé, in GERARD, Philippe; OST, François; KERCHOVE, M. van de. Droit et intérêt. Vol. II. Bruxelles: Publications des Facultés Universitaires Saint-Louis, 1990.

. Júpiter, Hércules, Hermes: Tres Modelos de Juez. Doxa, n. 14. Alicante: Universidad de Alicante, 1993.

PÉREZ-PERDOMO, Rogelio. Rule of Law and Lawyers in Latin America. The annals of the American Academy of Political and Social Science, v. 603, n. 1, p. 179-191, 2006. Disponível em : <http://ann.sagepub.com/cgi/reprint/603/1/179>.

PINHEIRO, Armando Castelar (org.). Judiciário e Economia no Brasil. São Paulo: Sumaré, 2000.

PIZA, João. A face neocollorida. Folha de São Paulo, São Paulo, 05 abr. 1997. Caderno 3, p. 2.

POSNER, Richard. El Análisis Económico del Derecho. México: Fondo de Cultura Económica, 2000.

PRILLAMAN, William C. The Judiciary and Democratic Decay in Latin America: Declining Confidence in the Rule of Law. Westport : Praeger, 2000.

RAWLS, John. A Theory of Justice. Cambridge: Harvard University Press, 1971. 
REHNQUIST, William H. The Supreme Court, New York: Vintage Books, 1987.

RIPOLL, Julieta Lemaitre. El Coronel Sí Tiene Quien Le Escriba: La Tutela Por Mínimo Vital En Colombia. In: SEMINARIO EN LATINOAMÉRICA DE TEORÍA CONSTITUCIONAL Y POLÍTICA, Rio de Janeiro, 16-19 jun. 2005. Trabalho apresentado. Disponível em: < http://islandia.law.yale.edu/sela/sela2005.htm>.

ROSEMBERG, Gerald N. The Hollow Hope: Can the Courts Bring About Social Change? Chicago: University of Chicago Press, 1991.

RUBENSTEIN, William B. The Concept of Equality in Civil Procedure. Cardozo Law Review, v. 23, n. 5, 2002.

RUIZ-TAGLE, Pablo. Poverty and the Creation of Fundamental Rights. In: SEMINARIO EN LATINOAMÉRICA DE TEORÍA CONSTITUCIONAL Y POLÍTICA, Rio de Janeiro, 16-19 jun. 2005. Trabalho apresentado. Disponível em: $<$ http://islandia.law.yale.edu/sela/sela2005.htm $>$.

SABEL, Charles F.; SIMON, William H.. Destabilization Rights: How Public Law Litigation Succeeds. Harvard Law Review, v. 117, p. 1015-1101, 2004.

SADEK, Maria Tereza (coord.). Pesquisa AMB 2005. Relatório de Pesquisa. São Paulo, 2005. Disponível em: <http://www.amb.com.br/portal/docs/noticias/ pesquisaamb2005.pdf>. Acesso em 25 out. 2005. . O Ministério Público e a Justiça no Brasil. São Paulo: Sumaré, 1997.

SALLES, Carlos Alberto de. Entre a Razão e a Utopia: a Formação Histórica do Ministério Público. In: VIGLIAR, J. M. M. e MACEDO JÚNIOR, R. P. (Coord.). Ministério Público II: Democracia . São Paulo: Atlas, 1999. . Execução Judicial em Matéria Ambiental. São Paulo: Revista dos Tribunais, 1999.

SANTOS, J.M. de Carvalho. Código Civil Brasileiro Interpretado. Vol. II. 3. ed.. São Paulo: Freitas Bastos, 1944. 
SCALIA, Antonin. A Matter of Interpretation (with commentary by Amy Gutmann (ed.)). Princeton: Princeton University, 1997.

. The Doctrine of Standing as an Essential Element of the Separation of Powers. Suffolk University Law Review, v. 17, p. 881-ss., 1983.

SCHOENBROD, David. Power Without Responsability: How Congress Abuses the People Through Delegation. New Haven: Yale University Press, 1993.

SCHORSKE, Carl E. Viena Fin-de-Sciècle. São Paulo: UNICAMP/Companhia das Letras, 1990.

SEGAL, Jeffrey A.; SPAETH, Harold J. The Supreme Court and the Attitudinal Model Revisited. Cambridge: Cambridge University Press, 2002.

SEMINÁRIO NACIONAL DA REFORMA DO PODER JUDICIÁRIO, DESENVOLVIMENTO ECONÔMICO E DEMOCRACIA, 1, 6 jan. 2002. Cadernos Direito $G V n^{o} 3$ - Seminários. Escola de Direito da Fundação Getulio Vargas e Jornal Valor Econômico. São Paulo: Fundação Getúlio Vargas, 2002. Disponível em: $\quad<$ http://www.edesp.edu.br/files/artigos/Reforma\%20do\%20 Judiciario.pdf $>$.

SEN, Amartya K. Inequality Reexamined. Cambridge: Harvard University Press, 1992. . What do we want from a theory of justice? 2005. Paper inédito apresentado ao Law, Economics \& Organization Workshop (Yale Law School), New Haven, 24 mar. 2005.

SHAPIRO, Martin. Courts. In: GREENSTEIN, Fred; POLSBY, Nelson (ed.). Handbook of Political Science. Vol. 5. Massachusetts: Addison-Wesley Pub Co., 1975.

SIDGWICK, Henry. The Methods of Ethics. Indianapolis: Hackett Publishing Company, 1981.

SILVA, Ovídio A. Baptista da; GOMES, Fábio Luiz. Teoria Geral do Processo. São Paulo: Revista dos Tribunais, 1997 
STONE SWEET, Alec. Judicialization and the Construction of Governance. Comparative Political Studies, v. 32, n. 2, p. 147-184, 1999.

STONE, Alec. Complex Coordinate Construction in France and Germany. In: TATE, C. Neal; VALLINDER, Tobjörn (ed.). The Global Expansion of Judicial Power. New York: New York University Press, 1995.

. The Birth of Judicial Politics in France: the Constitutional Council in Comparative Perspective. New York: Oxford University Press, 1992.

STONE, Christopher D. Should Trees Have Standing? University of South California Law Review, v. 45, p. 450-ss., 1972.

STOTZKY, Irwin P. (ed.). Transition to Democracy in Latin America: The Role of the Judiciary, San Francisco: Westwiew Press, 1993.

STOTZKY, Irwin P. e NINO, Carlos S., The Dificulties of the Transition Process. In: Irwin P. Stotzky (ed.), Transition to Democracy in Latin America: The Role of the Judiciary, San Francisco: Westwiew Press, 1993, p. 3.

SUNDFELD, Carlos Ari. Fundamentos de Direito Público. 3. ed. São Paulo: Malheiros, 1997.

SUNSTEIN, Cass R. et al. Predictably Incoherent Judgments. Stanford Law Review, v. 54, p. 1153-ss., 2001-2002.

SUNSTEIN, Cass R. Free Markets and Social Justice. New York: Oxford University Press, 1997. . Lochner's Legacy. University of Columbia Law Review, v. 87, p. 873-ss., 1987. . What's Standing After Lujan? Of Citizen Suits, 'Injuries' and Article III. Michigan Law Review, v. 91, p. 163-ss., 1992-1993.

TALAMINI, Eduardo. Coisa Julgada e sua Revisão. São Paulo: Revista dos Tribunais, 2005. 
TARUFFO, Michele. Il Processo Civile 'Adversary' Nell'Esperienza Americana. Padova: CEDAM, 1979.

TATE, C. Neal. Why the expansion of judicial power? In: TATE, C. Neal; VALLINDER, Tobjörn (ed.). The Global Expansion of Judicial Power. New York: New York University Press, 1995.

TEUBNER, Gunter. Substantive and Reflexive Elements in Modern Law. Law \& Society Review, v. 17, p. 239-ss., 1989.

TOCQUEVILLE, Alexis de. The Old Regime and the French Revolution. New York: Anchor, 1955.

TUSHNET, Mark. Alternative Forms of Judicial Review. Michigan Law Review, v. 101, p. 2781-ss., 2002-2003.

. Civil Rights and Social Rights: The Future of the Reconstruction Amendments. Loy. L. A. L. Review, v. 25, p. 1207-ss., 1991-1992.

. New Forms of Judicial Review and the Persistence of Rights - and Democracy Based Worries. Wake Forest Law Review, v. 38, p. 813-ss., 2003.

. Non-Judicial Review. Harvard Journal on Legislation, v. 40, p. 453-ss., 2003.

. Social Welfare Rights and the Forms of Judicial Review. Texas Law Review, v. 82, p. 1895-ss., 2003-2004.

. State Action, Social Welfare Rights, and the Judicial Role: Some Comparative Observations. Chi. J. Int'l L, v. 3, p. 435-ss., 2002.

. The Warren Court In Historical And Political Perspective. Charlottesville: University of Virginia Press, 1993.

UNGER, Roberto M. False Necessity: Anti-Necessitarian Social Theory in the Service of Radical Democracy From Politics: A Work in Constructive Social Theory. New York: Verso, 2002. 
VALLINDER, Tobjörn. When the Courts Go Marching In. In: TATE, C. Neal; VALLINDER, Tobjörn (ed.). The Global Expansion of Judicial Power. New York: New York University Press, 1995.

VALLINDER, Torbjörn (ed.). INTERNATIONAL POLITICAL SCIENCE REVIEW, v. 15, n. 2, 1994.

VERGARA, Rodrigo. OAB Pede que TJ Não Casse Liminar Contra Privatização. Folha de São Paulo, São Paulo, 10 abr. 1997. Caderno 3, p. 11.

VERISSIMO, Marcos P. Aproximação Sistemática ao Controle Judicial das Agências de Regulação Econômica no Brasil. São Paulo, USP, 2002. Dissertação (mestrado) Programa de Pós-Graduação em Direito, Faculdade de Direito, São Paulo, 2002.

. Controle Judicial da Atividade Normativa das Agências de Regulação Brasileiras. In: Alexandre Santos de Aragão (ed.), Poder Normativo das Agências Reguladoras. Rio de Janeiro: Forense, 2006 (no prelo).

VIANNA, Luiz Werneck et al. Corpo e Alma da Magistratura Brasileira. 3 ed. Rio de Janeiro: Revan, 1997.

VIANNA, Luiz Werneck; BURGOS, Marcelo. Revolução Processual do Direito e Democracia Progressiva. In: VIANNA, Luiz Werneck (org.). A Democracia e os Três Poderes no Brasil. Rio de Janeiro: IUPERJ, 2003.

VIANNA, Luiz Werneck et al. A Judicialização da Política e das Relações Sociais no Brasil, Rio de Janeiro: Revan: 1999.

VIEIRA, Oscar Vilhena. Supremo Tribunal Federal: Jurisprudência Política. Editora Malheiros, 2002.

VITA, Alvaro. A Justiça Igualitária e seus Críticos. São Paulo: Unesp, 2000. . Justiça Liberal: Argumentos Liberais contra o Neoliberalismo. São Paulo: Paz e Terra, 1993. 
VONCANSEK, Mary L. Constitutional Judicial Activism in Italy. In: HOLLAND, Kenneth M. (ed.). Judicial Activism in Comparative Perspective. New York: St. Martins's Press, 1991.

. Constitutional Politics in Italy, New York: St. Martins’s Press, 1999.

WABNITZ, Hans-Werner. Access to Court: Examples of World Bank Projects which Include Activities to Facilitate Access to Court. In: CONFERÊNCIA DA COMISSÃO INTERNACIONAL DE JURISTAS, Varsóvia, 30 set. - 3 out. 1999. Trabalho apresentado. Disponível em: <http://papers.ssrn.com/sol3/Delivery.cfm/ 991108201.pdf?abstractid=191555\&mirid $=2>$.

WALDRON, Jeremy. Rights. In: GOODIN: Robert; PETTIT, Philip (ed.). A Companion to Contemporary Political Philosophy. London: Blackwell, 2005.

WALLACH, H. G. Peter. Judicial Activism in Germany. In: HOLLAND, Kenneth M. (ed.), Judicial Activism in Comparative Perspective. New York: St. Martins's Press, 1991.

. Reunification and Prospects for Judicialization in Germany. In: TATE, C. Neal; VALLINDER, Tobjörn (ed.). The Global Expansion of Judicial Power. New York: New York University Press, 1995.

WALTMAN, Jerold L. Judicial Activism in England. In: HOLLAND, Kenneth M. (ed.). Judicial Activism in Comparative Perspective. New York: St. Martins's Press, 1991.

WATANABE, Kazuo et al. Código Brasileiro de Defesa do Consumidor Comentado pelos Autores do Anteprojeto. $7^{\mathrm{a}}$ ed. Rio de Janeiro: Forense Universitária, 2001.

- Modalidade de Mediação. Cadernos do Centro de Estudos Judiciários do Conselho da Justiça Federal, v. 22, p. 42-50. Disponível em: $<$ http://www.cjf.gov.br/revista/seriecadernos/vol22/artigo04.pdf $>$.

. Tutela antecipada e tutela específica das obrigações de fazer e não fazer. In: TEIXEIRA, Sálvio de Figueiredo (coord.). A reforma do CPC. São Paulo: Saraiva, 1996. 
WEBER, Max. Metodologia das Ciências Sociais. Parte 1. 4a ed. São Paulo: Cortez, 2001.

WINDSCHEID, Bernard; MÜTHER, Theodor. Polemica sobre la "actio". Buenos Aires: Ejea, 1974.

YEAZELL, Stephen C. Collective Litigation as Collective Action. University of Illinois Law Review, v. 1989, p. 43-68, 1989.

. Intervention and the idea of litigation: a commentary on the Los Angeles School Case. UCLA Law Review, v. 25, p. 245-ss., 1977-1978. 